\title{
A LABORATORY INVESTIGATION OF THE APPLICATION OF TRANSFER FUNCTIONS TO FLEXIBLE PAVEMENTS
}

\section{SEPTEMBER 1972 - NUMBER 34}

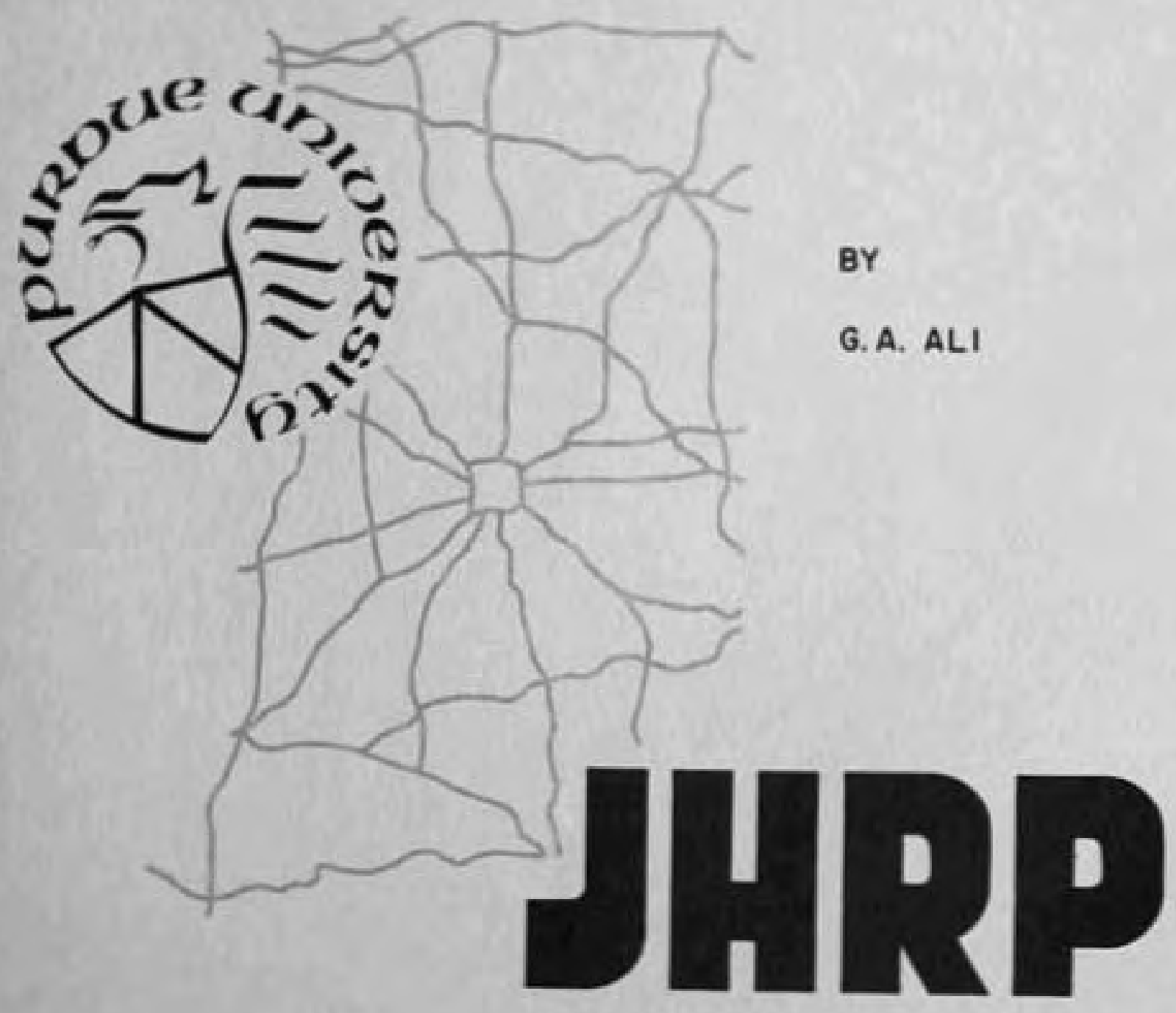

JOINT HIGHWAY RESEARCH PROJECT PURDUE UNVERITY AND 
Final Report

A LABORATORY INVESTIGATION OF THE APPLICATION OF TRANSFER FUNCTIONS TO FLEXIBLE PAVEMENTS

TO: J. F. McLaughlin, Director Joint Highway Research Project

FROM: H. L. Michael, Associate Director Joint Highway Research Project
September 7, 1972

Project: $c-36-6 z$

File: $2-4-26$

The attached Final Report titled "A Laboratory Investigation of the Application of Transfer Functions to Flexible Pavements" is submitted as fulfillment of the objectives of the Plan of Study approved by the Board on September 16, 1970, under title of "Response of Flexible Pavements to Static and Dynamic Loads Using Impulse Loading".

The research was conducted and the Report authored by Mr. G. A. Ali, Graduate Instructor in Research on our staff. Professors W. H. Goetz and M. E. Harr served as advisors and directors of this research effort.

The Final Report is submitted to the Board for acceptance as fulfillment of the objectives of the Study.

Respectfully submitted,

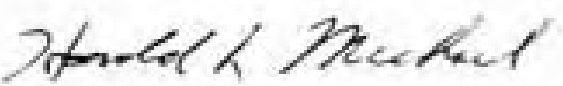

Harold L. Michael

Associate Director

HLM : ms

cc: W. L. Dolch

R. L. Eskew

W. H. Goetz

M. J. Gutzwiller

G. K. Hallock

R. H. Harrell
M. L. Hayes

C. W. Love 11

G. W. Marks

R. D. Miles

J. W. Miller

G. T. Satterly
C. F, Scholer

M. B. Scott

J. A. Spooner

N. W. Steinkamp

H. R. J. Walsh

E. J. Yoder 


\title{
Final Report
}

A LABORATORY INVESTIGATION OF THE APPLICATION OF TRANSFER FUNCTIONS TO FLEXIBLE PAVEMENTS

\author{
by \\ G. A. Ali \\ Graduate Instructor in Research \\ Joint Highway Research Project \\ Project No.: C-36-62 \\ File No.: $2-4-26$ \\ Conducted By \\ Joint Highway Research Project \\ Engineering Experiment Station \\ Purdue University \\ In Cooperation with \\ Indiana State Highway Commission
}

Purdue University

West Lafayette, Indiana

September 7, 1972 
Digitized by the Internet Archive in 2011 with funding from

LYRASIS members and Sloan Foundation; Indiana Department of Transportation

http://www.archive.org/details/laboratoryinvest00alig 


\section{ACKNOWLEDGMENTS}

Special thanks for advice, assistance and counsel in planning and conducting this research is given to Professors W. H. Goetz and M. E. Harr. Appreciation for their stimulating and useful discussions is also given to Professors E. J. Yoder and A. H. Al-Abiad, the latter from the School of Electrical Engineering.

The author takes this opportunity to thank the authorities of the Joint Highway Research Project of Purdue University, Professor J. F. McLaughlin, Director, for material help and support of this research. 
TABLE OF CONTENTS

Page

LIST OF TABLES . + . . . . . . . . . . . . . . . vi vi

LIST OF FIGURES. + . . . . . . . . . + . . vii

LIST OF SYMBOLS. . . . . . . . . . . . . . $x$ ABSTRACT . + . . . . + . . . . . . . . xiii

INTRODUCTION. . . . . . . . . . . . . . . 1

BACKGROUND AND STATE OF THE ART . . . . . . . + 6

Application of Elastic Theory . . . . . . . 6

Developments from Viscoelastic Theory. : . $: .8^{*} 8$

Use of Dynamic Mode1s... . . . . . . . 12

Transfer Function Approach . . . . . . . 16

Laboratory Studies of Flexible Pavements. : . . 19

THEORETICAL ANALYSIS . . . . . . . . . . . . 23

Assumptions . . . . . . . . . . . 23

Experimental Determination of the Impulse Response : 25

Prediction Theory . . . . . . . . . . . . 29

Solution for Step Loading . . . . . . . . . 29

Solution for Repeated Loading. . . . . . . 31

Total Response... . . . . . . . . 33

Permanent or Accumulative Response . . . . 35

EXPERIMENTAL INVESTIGATION * . . . . . . . . 36

Scope . . . . . . 36

Approximate Design of the Model Pavenents . . . . 37

Materials and Preparation of the Model Pavements . . 38

Subgrade Soil . . * . . * . . . . . 39

Base Course. . . . . . . . . . . . . 46

Surface Course. * . . . . . . . . . . . 48

Instrunentation . . . . . . . . . . . . 53

Test Procedures. . . . . . . . . . . . . 60

Impulse Load Tests . . . . . . . . . . . 65

Static Load Tests. . . . . . . . . . . . 65

Repeated Load Tests... . . . . . . . 65 
TABLE OF CONTENTS (cont'd.)

Page

RESULTS AND DISCUSSION . . . . . . . . . . 72

Impulse Load Test Results. . . . . . . . + . 73 Normal Distribution and the Deflection Basin. : 73

Response Function of Flexible Pavements . . . . 90

Form of the Response Function. . . . . . . . 97

Check for the Response Function . . . . . . . 101

Load-Independency of the Response Function . + + 101

Effect of Temperature on the Response Function. . 105

Effects of Surface Course Thickness and Spatial

Location................ . . . 107

Static Load Results. . . . . . . . . . . . 107

Repeated Load Results . . . . . . . . . . . 113

Corner Loading Test Results . . . . . . . . . 119

CONCLUSIONS . . . . . . . . . . . . . . . 122

SUGGESTIONS FOR FURTHER RESEARCH . . . . . . . . 125

BIBLIOGRAPHY. . . . . . . . . . . . . 129

APPENDICES

Appendix A: Reduced Impulse Test Data . + . + . 137

Program . . . . . . . . . . 137

Reduced Data. . . . . . . . . 143

Appendix B: Static Load Program . . . . + + 195

Appendix C: Repeated Load Program. . . . . . . 197

VITA . . . . . . . . . . . . . 200 


\section{LIST OF TABLES}

Table

Page

1. Physical Properties of the Subgrade Soil . . . 40

2. Sieve Analysis of Aggregate for the Surface

Course Mixture . . . . . . . . . . 49

3. Results of Tests on Asphalt Cement . . . . . 51

4. Typical Format for LVDT Calibration . . . . . 61

5. Typical Data Reduction for Impulse Test. . . . 67

6. Typical Data Reduction for Static Test . . . . 71

7. Typical Data Reduction for Repeated Test . . . 71

8. Peak Deflections from Impulse Tests . . . . . 74

9. Values of $y_{0}$ and $D$ in the Equation $y(x)=y_{0} e^{-D x^{2}} . \quad 83$

10. Descriptive Parameters in the Response Functions

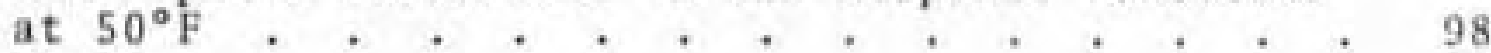

11. Descriptive Parameters in the Response Functions at $75^{\circ} \mathrm{F} .+.+.+.+.+.+99$

12. Descriptive Parameters in the Response Functions at $100^{\circ} \mathrm{F} .+.+.+.+.+100$

13. Typical Predicted and Measured Deflection

Functions. . . . . . . . . . . 102

14. Typical Comparison of Response Functions
Obtained from Different Load Magnitudes. . . 104

15. Predicted and Measured Static Load Deflections . 109

16. Predicted and Measured Haversine Load

Deflections . . . . . . . . . . . 114

17. Effects of Confinement . . . . . . . . 121

18. Comparison of $R^{2}$ for Different Models . . . 126 


\section{LIST OF FIGURES}

\section{Figure}

1. Procedure for Pavenent Evaluation . . . . 4

2. Mechanical Models Commonly Used... . . . 14

3. Typical Pulse Shapes Produced by a Moving Wheel Load............. . . 15

4. Schenatic Representation of the System Functions........... 24

5. Experimental Determination of System Response Function. . . . . . . . . 28

6. Haversine Input and Output Functions . . . . 32

7. Grain Size Distribution Curve for the Subgrade Soil . . . . . . . . . . 41

8. Moisture-Density Relationship of the Subgrade Soil . . . . . . . . . . 42

9. The Speedy Moisture Tester. . . . . . . . 43

10. Calibration of the Speedy Moisture Tester for the Subgrade Soil. . . . . . . . . . 44

11. Subgrade Soil under Compaction . . . . . . 45

12. Gradation Curve for Indiana Size No. 53 Base Course. . . . . . . . . . 47

13. Gradation Curve for Indiana Type B Surface Mixture .......... . . . 50

14. Bituminous Mixture under Compaction. . . . . 54

15. Leveling of the Surface Course . . . . . . 55

16. Loading Frane and Model Pavenent Support . . . 57

17. Generation of Inpulse . . . . . . 58 
vili

LIST OF FIGURES (cont'd.)

Figure

Page

18. Location of Plate and LVDT's: Corner Loading . 59

19. General View of Test Setup. . . . . . + 62

20. Close View of Test Setup . . . . . . . 63

21. Coding of Data. . . . . . . . . 64

22. Typical Traces of an Impulse Load Test. . . . 66

23. Typical Traces of a Static Load Test . . . . 68

24. Typical Traces of a Repeated Load Test. . . . 70

25. Peak Deflection Profiles from Impulse Tests 1-Inch Surface, $50^{\circ} \mathrm{F}$. . . . . . . . 75

26. Peak Deflection Profiles from Impulse Tests 1 -Inch Surface, $75^{\circ} \mathrm{F}$.

27. Peak Deflection Profiles from Impulse Tests 1-Inch Surface, $100^{\circ} \mathrm{F} . . .+. .+. .977$

28. Peak Deflection Profiles from Impulse Tests 2-Inch Surface, $50^{\circ} \mathrm{F}$. . . . . . . . . 78

29. Peak Deflection Profiles from Impulse Tests 2-Inch Surface, $75^{\circ} \mathrm{F}$. . . . . . . . 79

30. Peak Deflection Profiles from Impulse Tests 2-Inch Surface, $100^{\circ} \mathrm{F}$. . . . . . . . 80

31. Typical Comparison of Deflection Profiles from Impulse Tests......... . . 82

32. $y_{0}$ Versus Temperature - 1-Inch Surface. . . 85

33. $y_{0}$ Versus Temperature - 2-Inch Surface. . . 86

34. $y_{0}$ Versus Surface Thickness $-50,75,100^{\circ} \mathrm{F}$. 88

35. D Versus Temperature - 1-Inch, 2-Inch Surfaces. 89

36. Input Load and Output Deflection Functions Data for 1HI1. . . . . . . . 91

37. Input Load and Output Deflection Functions Data for 1 HI 2 


\section{LIST OF FIGURES (cont'd.)}

Figure

38. Input Load and Output Deflection Functions Data for 1 HI3............ . . 93

39. Response Functions - Data fron 1H11. . . . . 94

40. Response Functions - Data from 1HI2. . . . . 95

41. Response Functions - Data fron 1HI3. . . . . 96

42. Curves of a Paraneter Versus Temperature . . . 106

43. Typical Predicted and Measured Static Load Deflections - 1-Inch Surface, $75^{\circ} \mathrm{F}$. . . . 110

44. Typical Predicted and Measured Static Load Deflections - 1-Inch Surface, $100^{\circ} \mathrm{F}$. . . . 111

45. Typical Predicted and Measured Static Load Deflections - 2-Inch Surface, $50^{\circ} \mathrm{F} . . . .112$

46. Typical Predicted and Measured Repeated Load Deflections - 1-Inch Surface, $75^{\circ} \mathrm{F} . . .115$

47. Typical Predicted and Measured Repeated Load Deflections - 1-Inch Surface, $100 \mathrm{~F}$. . . . 116

48. Typical Predicted and Measured Repeated Load Deflections - 2-Inch Surface, $50^{\circ} \mathrm{F} .$. 


\title{
LIST OF SYMBOLS
}

\author{
A Constant \\ C Constant \\ $c_{i}$ Coefficients of the Dirichlet series \\ c Viscosity coefficient \\ D Constant \\ E: Elastic modulus of surface course \\ $\mathrm{E}_{2} \quad$ Elastic modulus of base course \\ E, Elastic modulus of subgrade \\ $\mathrm{E}_{i}$ Exponents of the Dirichlet series \\ Fo Magnitude of input forcing function \\ $F_{p} \quad$ Peak value of impulse 1oad \\ $F(t) \quad$ Input forcing function \\ $F(s) \quad$ Laplace transform of $F(t)$ \\ G(s) Transfer function \\ $G(t)$ Response function \\ $G\left(t_{k}\right) \quad$ Vector quantity of the response function at \\ time $t_{k}$ \\ h Compacted thickness of layered material \\ $I(t) \quad$ Input \\ $I\left(t_{k}\right) \quad$ Value of input at time $t_{k}$ \\ $I(s)$ Laplace transform of $I(t)$ \\ K Conversion factor
}




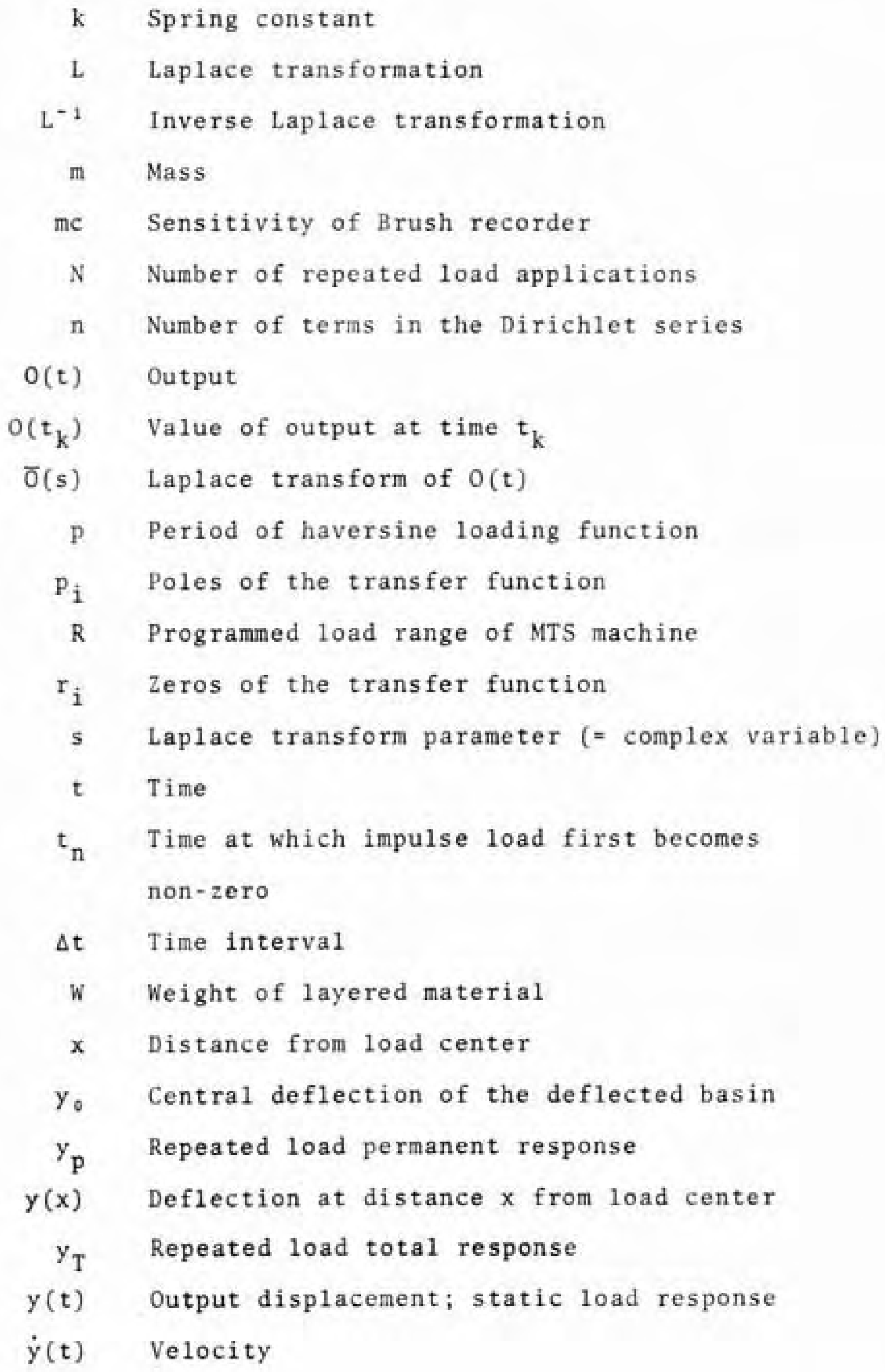




$$
\begin{aligned}
\ddot{y}(t) & \text { Acceleration } \\
\bar{y}(s) & \text { Laplace transform of } y(t) \\
\alpha, B, \gamma, \delta, \epsilon & \text { Constants } \\
\gamma_{w e t} & \text { Density of compacted 1ayered material } \\
\varphi & =\tan ^{-1}\left(\frac{\gamma}{B}\right) \\
\varphi_{2} & =\tan ^{-1}\left(\frac{\gamma-\omega}{B}\right) \\
\varphi_{2} & =\tan ^{-1}\left(\frac{\gamma+\omega}{B}\right) \\
\omega & \text { Frequency }
\end{aligned}
$$




\section{ABSTRACT}

A1i, Galal Abda11a. Ph.D., Purdue University, August 1972. A Laboratory Investigation of the Application of Transfer Functions to Flexible Pavements. Co-Major Professors: William H. Goetz and Milton E. Harr.

Transfer function theory was applied to examine the behavior of flexible pavements. Two convolution techniques, one numerical and the other analytical, were employed. The numerical convolution was used to derive pavement response functions from impulse testing of three-1ayer, flexible model pavements. The analytical convolution formed the basis for calculating deflections resulting from static and repeated loads.

It was hypothesized that more significant parameters than commonly used could be obtained under controlled laboratory conditions. By using non-1inear regression, the response functions were approximated by a mathematical model to include these parameters. The derived model was used as input in the analytical convolutions. The adequacy of the developed mode1s was verified by comparing predicted and measured deflections.

Curve-fitting of the dynamic peak deflection data, by the non-1inear regression, resulted in a mathematical function for the deflection basin. 
A silty sand subgrade, a crushed aggregate base, and an asphalt concrete surface constituted the components of the three-layer systems. Each layer material was characterized by a series of conventional laboratory tests. Model pavements, of two different surface course thicknesses, were tested statically and dynamically at three different stress levels. Test temperatures were 50,75 and $100^{\circ} \mathrm{F}$. Deflections were measured at five spatial locations.

The following are the primary findings of this research:

1. The profile of peak deflections of a flexible highway pavement can be described by the equation

$$
y(x)=y_{0} e^{-D x^{2}}
$$

where $y(x)$ is the deflection at a distance $x$ from the load center, $y_{0}$ is the central deflection and $D$ is a constant reflecting the attenuation of the deflection profile with $x$.

2. The central deflection $y_{0}$ increases with increases in temperature, and decreases with increasing surface course thickness. Increases in temperature $\left(50^{\circ} \mathrm{F}-100^{\circ} \mathrm{F}\right)$ or surface course thickness ( 1 inch and 2 inches) decrease the value of the parameter D.

3. The time-dependent behavior of a flexible pavement can be represented by a response function $G(t)$ which is a function of time $t$. It is possible to obtain this function from a single impulse test on the pavement. The response function is independent of the magnitude of the impulse load.

4. The response function of a flexible highway pavement is of the form 


$$
G(t)=\alpha e^{-\beta t} \sin \gamma t
$$

where $\alpha, \beta$ and $\gamma$ are descriptive parameters in the response function.

5. Parameters in the response function are believed to be pavement properties that provide for better understanding of its behavior than those currently used.

6. Temperature, surface course thickness and spatial location have their respective influences on the response function. Increases in temperature increase the value of the $\alpha$ parameter in the response function, while increasing surface course thickness or the distance from the load center decreases the value of $\alpha$. The $\beta$ and $\gamma$ parameters do not seem to be affected appreciably by the above factors.

7. Transfer function theory is capable of predicting static or repeated load deflections of flexible pavements. The favorable agreement between predicted and measured values of the deflections in this study validates the hypothesis that the parameters in the response function are material descriptors which are independent of the type of load input. 


\section{INTRODUCTION}

The pursuit of a rational method for designing and evaluating pavenents requires considerable knowledge of their response behavior to realistic loadings. The ability of a pavement structure to withstand such imposed loads can be expressed in terms of primary and ultimate response modes $[1,2] .^{*}$ In the primary response, the magnitudes of developed stresses, strains or deflections can be used, whereas failure must be considered in the ultimate response. Hence, an essential part in pavement design is the development of a procedure to analyze a pavement system for representative input stimuli. Another necessary requirement is to define a failure criterion in terms of the ultimate responses, for example by limiting deflection, so that the designer may assign allowable values to these quantities. When deflection is considered as the criterion, it must be supplemented by other measurements, such as the slope of the deflection profile. Knowledge of the analytic form of the deflection profile is a prerequisite to determining its slope.

Although the question as to what causes failure in asphaltic concrete pavements is a complex one, several failure mechanisms have been postulated $[3,4,5,6]$.

* Numbers in brackets refer to entries in the Bibliography. 
Surface cracking and rutting may be caused by the effect of direct wheel loads, shear displacements and further compaction of the base structure, or due to irrecoverable deformations in the subgrade material resulting in creep or plastic flow. The elastic or recoverable portion of the deformations in the bottom layers under the action of repeated loads may result in fatigue failure, whereas insufficient subgrade shear strength can lead to shear type failure. Brittle surface cracking may be caused by non-load-associated stresses such as those effected by changes in temperature.

Current mathematical models to predict pavement response and to evaluate its behavior generally evolve from elastic and viscoelastic theories. These models incorporate geometric aspects and material properties within a system of equations which, in turn, are solved so as to satisfy selected boundary conditions. However, any mode1, required to be predictive, must be inclusive of realistic in-situ material properties. Also, pavement materials, and particularly bituminous concrete, are time- and temperature-dependent. At the present time no single theory of pavement behavior that considers time- and temperature-dependent characteristics of pavement systems is used in designing or evaluating pavements. Thus, a need exists to obtain parameters or functions capable of completely describing the time- and temperature-dependent material properties of pavements subjected to static or dynamic loads. 
A new approach undertaken in the present study to evaluate pavement behavior deals with the primary response mode. The basis of the investigation is the transfer function theory that has been applied successfully in the synthesis and design of various systems in other fields of engineering .

This investigation extends the transfer function concepts to flexible pavements. More significant material properties, or indicators, than commonly hypothesized are defined and determined under controlled laboratory conditions. The adequacy of the developed mathematical-experimental models is evaluated by comparing predicted responses due to static and dynamic loads with experimentally measured values. The effect of surface course thickness, temperature and spatial location on the dynamic parameters and the predictions are examined.

In addition, it is hypothesized that the deflection basin of a pavement follows a normal distribution curve. A mathematical form is obtained to fit the deflection basin.

The procedure to achieve the above objectives as a pavement evaluation tool is depicted in the flow chart of Figure 1. A known impulse load is applied to a pavement system. The resulting output deflections are measured as functions of time at several locations on the pavement surface. The peak deflections are curve-fitted using a computer program NONLINR. A mathematical function is thus 


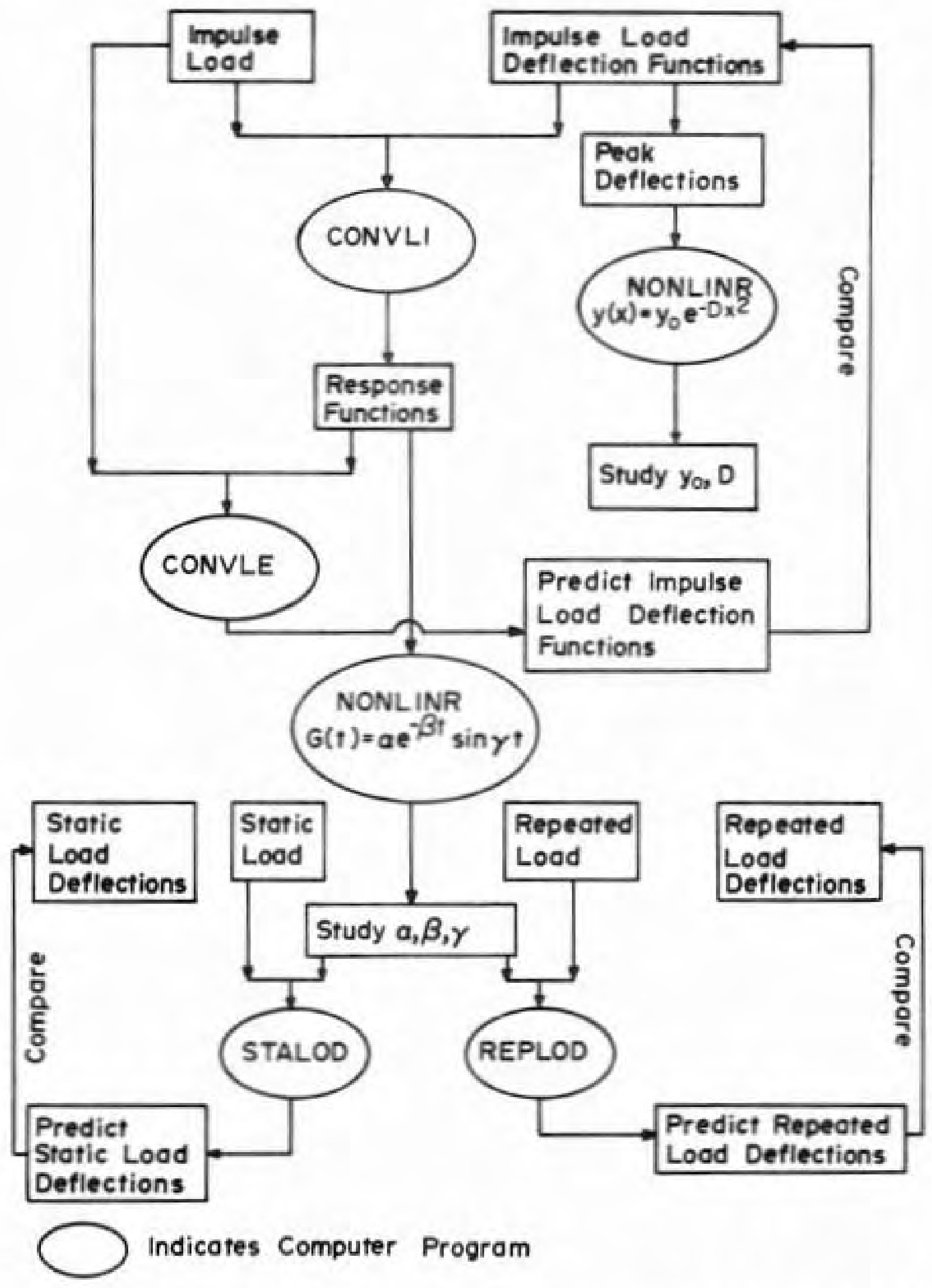

FIGURE I PROCEDURE FOR PAVEMENT EVALUATION 
obtained to describe the deflection basin. The parameters in this function are studied.

The time-dependent input and outputs resulting from the impulse tests are analyzed within a formulated theory to give response functions. A computer subroutine CONVLI is employed. The response functions are verified using subrout ine CONVLE.

A mathematical model for the response functions is evolved through NONLINR. This model is convoluted analytically with step and repeated load functions. Computer programs STALOD and REPLOD facilitate the respective calculations. Predicted and measured responses are compared. 
BACKGROUND AND STATE OF THE ART

In this section a literature review is presented which develops the necessary background and state of the art for this investigation. Five aspects of material characterization and pavement studies pertaining to this study are presented:

1. Application of elastic theory.

2. Developments from viscoelastic theory.

3. Use of dynamic models.

4. Transfer function approach.

5. Laboratory studies of flexible pavements.

Application of Elastic Theory

One of the earliest applications of the theory of elasticity to an infinite layer medium was the investigation reported by Boussinesq [7]. Later, Burmister [8, 9] presented the stresses and displacements in two- and threelayered systems. The layer theory was further extended by Fox [10], Acum and Fox [11], Mehta and Veletsos [12], Jones [13] and others. General1y, all these theories have in common the following assumptions: (a) Each of the system layers is a continuous, homogeneous, isotropic, linearly elastic medium of infinite horizontal extent; (b) each layer 
is continuously in contact with, and supported by, the underlying layer; (c) the surface loading can be represented by a vertical pressure uniformly distributed over a circular area; (d) inertia forces are negligible; and (e) displacements are smal1. That no pavement layer can satisfy these restrictions, except for extreme cases, is generally accepted. Furthermore the above theories do not consider dynamic loading, since the stress function technique, which underlies these methods, is applicable only to static loads. Avramesco [14] outlined a mathematical solution for computing displacements in elastic layered structures. The method accounts for the dynamic phenomena in pavements and, according to Avramesco, can be extended to the viscoelastic case. However, only qualitative description of the dynamic behavior was reported without numerical results.

How closely the material properties are represented in any theory is reflected in its predictive capability. The representation of material properties by two elastic constants (as is required by elastic theory) is simply a mathematical expedient. From laboratory tests on specimens of bituminous mixtures, Busching, Goetz and Harr [15] determined six independent coefficients necessary to describe the stress-strain relationships considering the material as homogeneous and transversely anisotropic when subjected to small strains.

Despite the several shortcomings that elastic layer theory has, this model can be used as a first approximation. 
However, it remains to be determined how the performance of pavements in the real world is related to the prediction of stresses in idealized elastic pavement systems.

\section{Developments from Viscoelastic Theory}

For several years the component materials of a pavement system have been recognized to have time dependent stressstrain properties due to consolidation and creep $[16,17]$. Thus, to overcome the limitations imposed by the assumptions of time-independent elastic materials, the viscoelastic approach was introduced into material characterization and pavement analysis.

Viscoelastic model representations of soils have been discussed by Schiffman [18]. Lee [19] and Lee and Rogers [20] presented more general methods of viscoelastic stress analysis. Secor and Monismith [21] studied the viscoelastic properties of bituminous concrete using a four element model. Papazian [22] represented asphaltic concrete by a mechanical model consisting of five Kelvin units in series with one Maxwe11 unit. He pointed out that an infinite number of Kelvin units would be needed for accurate representation of the material.

The development of the correspondence principle for isotropic media in 1955 by Lee [23], and shortly thereafter its extension by Biot [24] to include anisotropic media, made possible the analysis of pavements using time dependent material properties. The viscoelastic solutions are based 
on the premise that the time dependent boundary value problem can be reduced to an elastic model if all time varying quantities are replaced by their equivalent Laplace transforms and the elastic constants by operator forms of the stress-strain relations. Perloff and Moavenzadeh [25] determined vertical deflections for a static load and a point load moving at a constant velocity on the surface of a homogeneous, isotropic, linear viscoelastic half-space.

The solutions to two-1ayer systems, where either one or both components were considered viscoelastic, was the subject of the papers pub1ished by Pister and his co-workers 126,27 , $28,29]$. The problem of a viscoelastic asphaltic concrete beam on a set of independent springs approximating a Winklertype foundation was investigated for both a stationary load [26] and a concentrated moving force [27]. The case when the top layer was assumed to be elastic and the subgrade to be viscoelastic was solved by Pister and Williams [28] and Hoskin and Lee [30]. Both layers were considered to have time dependent (viscoelastic) properties in the analysis presented by Pister [29] and Huang [31].

In response to the demand of research workers for improvements on pavement models to include realistic material representation, more elaborate models were used to solve the three- and four-1ayer viscoelastic problems [2, 31, 32]. Barksdale and Leonards [33] presented a viscoelastic analysis for three- and four-layer pavement systems subjected to 
repeated loads. An attempt was made to compare the theoretical predictions of the resilient and permanent deformations due to repeated loads with those determined at the MSHO Road Test. The measured permanent surface deflection for the AASHO Road Test Section was more than three times the predicted value. The discrepancy was mainly due to the assumption of an elastic base course made in the viscoelastic analysis, while the results of the AASHO Road Test indicated that 59 percent of the permanent deformation occurred in the base and subbase. Thus, in predicting flexible pavement performance, all layered materials must be considered to have time dependent characteristics.

Based on the fact that pavement materials are viscoelastic and temperature-dependent, Ku [34] proposed stressstrain relations that accounted for temperature variations. Although the temperature-dependent relations were verified experimentally $[35,36]$, the application of the stress-straintemperature constitutive relations to the solution of layered systems has yet to be developed. Recently, Moavenzadeh [37] extended the primary response model for a three-layer viscoelastic system [2] to include failure in flexible pavements. The developed mathematical formulation accounts for environmental conditions, such as temperature and moisture, but no numerical results were provided.

When different temperatures are being considered, the equivalence of spring and dashpot models are lost. To obtain 
the temperature-dependent constitutive relations for viscoelastic materials, either more simplifying approximations must be made or data used directly [38].

Each of the above investigations, within the framework of viscoelastic theory, attempted to take into consideration the time dependence of pavement materials and consequently provided an insight into their behavior; however, the correspondence principle requires that the associated elastic problem must be amendable to solution. The elastic approach, in turn, imposed certain mechanistic material properties (constitutive relations) into the analysis inasmuch as the equations obtained from equilibrium conditions, strain definitions, and compatibility relations are less than the number of unknowns contained within these relationships.

In both elastic and viscoelastic theories, mathematical expediency has led to idealization of the constitutive relations. The combination of springs and dashpots selected to characterize the stress-strain properties of pavement layer materials depends on the individual investigator(s). Basically, the criterion is to obtain a better curve fit for the response sought. Usually, some difficulty is involved in taking the inverse Laplace transform to obtain the final solution.

Among the viscoelastic models commonly used are the Maxwe11 [39], Voigt-Kelvin [25], van der Poel (or Standard Solid) [40], four-element [21, 41] or combinations of these 
models $[22,31,33]$. The model constants are usua11y evaluated by running a creep test. The response to a unit step load is then approximated by the Dirichlet series

$$
\sum_{i=1}^{n} C_{i} e^{-t E_{i}}
$$

where $C_{i}$ and $E_{i}$ are constants, $t$ is time and $n$ is the number of terms desired. The exponents $\mathrm{E}_{i}$ are given specific values as suggested by Shapery [42] and the coefficients $C_{i}$ are determined by the linear least squares method of curve fit. It is noticed here that the material parameters $C_{i}$ are predetermined by the experimenter so as to avoid the non-linear set of equations that result if the error sum of squares is minimized with respect to each parameter [42].

One of the objectives of the present investigation is to determine the material properties defined by the response to a unit impulse load using a non-1inear least squares curve fitting technique. A computer subroutine [43] is employed for this purpose.

\section{Use of Dynamic Mode1s}

Recently, research workers have recognized the fact that pavements should be regarded as dynamic systems. The elastic and viscoelastic theories do predict, within a limited degree of accuracy, static and quasi-static stresses and displacements, but little is known about the dynamic behavior of pavements. Lattés, Lions and Bonitzer [44] attempted to 
include inertia effects but the method was in the development stage and no numerical results were published.

In dynamic models, the mass, dashpot and spring function represent, respectively, inertia, damping effect and restoring force, of a mechanical system. The two configurations most $1 y$ used to represent a road structure are shown in Figures 2-a and $2-b$, respectively, for a single degree of freedom (three-parameter) mode1 and a seven-parameter model. Using sustained vibrations and assuming the mechanical system of Figure 2-a to represent a road system, Heukelom [45] analyzed dynamic deflections of pavenents. Harr [46] used a three-parameter model to study the effect of vehicle speed on dynamic pavement deflections due to a rectangular pulse loading function. In conjunction with their study to calculate the transient responses of a pavement system, Szendrei and Freeme [47] experimentally determined the shape of the impulse to which a road is subjected under traffic loading. The two pulse shapes which were observed are illustrated in Figure 3. Simple as well as complicated models $[47,48,49$, 50] have been proposed to investigate the dynamic response of pavement systems. The inadequacy and shortcomings of such models have been discussed in the 1 iterature $[45,48,49,50]$. The fact that these models do not possess sufficient predictive capability to satisfy either existing or contemplated needs is not surprising since the representation of pavement behavior by a spring-mass-dashpot system is only a simple 


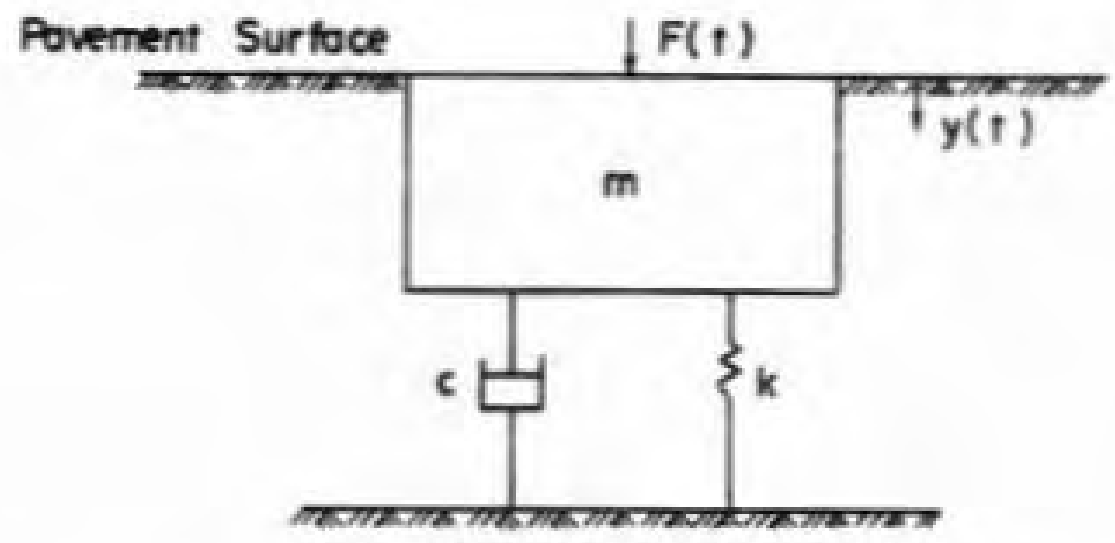

a. Three - Parometer Model

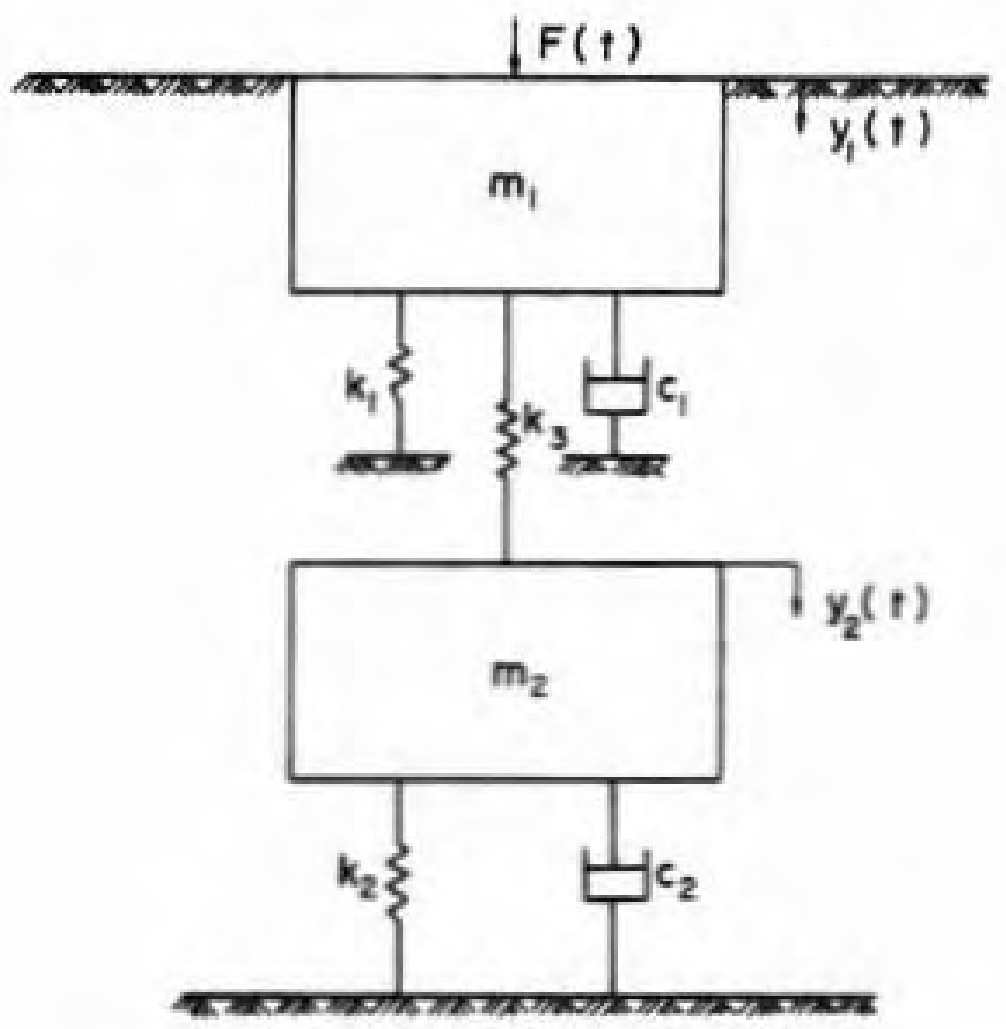

b. Seven-Parameter Model

FIGURE 2 MECHANICAL MODELS COMMONLY USED 


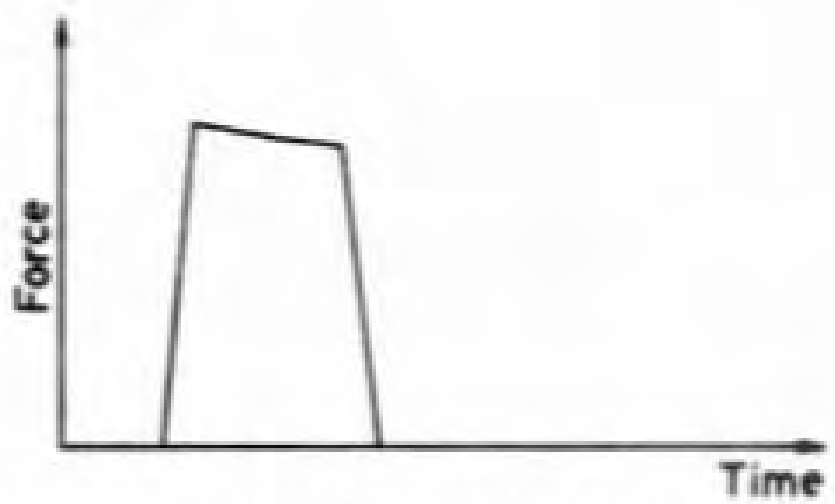

a. Rectangular Pulse Near the Tire Center

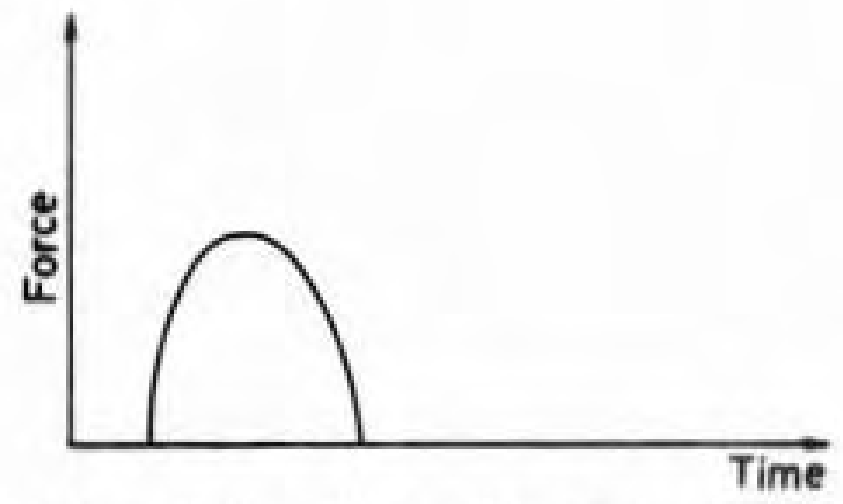

b. Holf-Sine Pulse Near the Tire Edge

FIGURE 3 TYPICAL PULSE SHAPES PROOUCED BY A MOVING WHEEL LOAD (47). 
idealized model in which distributed effects are approximated by lumped parameters. This is attributed to lack of a true model that would satisfactorily serve the purpose.

\section{Transfer Function Approach}

Based on transfer functions, several solutions to mechanical and electrical engineering problems are found in the 1iterature $[51,52,53,54]$. The transfer function represents the operator which, acting on the time-dependent input, yields the output of a dynamic system. When obtaining the transfer function analytically, the system parameters are defined by assumed differential equations. For example, the equation of motion for the system shown in Figure 2-a is given by

$$
m \ddot{y}(t)+c \dot{y}(t)+k y(t)=F(t)
$$

where $m=$ mass,

$$
\begin{aligned}
c & =v i s c o s i t y \text { coefficient, } \\
k & =\text { spring constant, } \\
y(t) & =\text { output displacement } \\
\dot{y} & =\text { velocity, } \\
\ddot{y}(t) & =\text { acceleration, } \\
F(t) & =\text { input forcing function, and } \\
t & =\text { time. }
\end{aligned}
$$

The transfer function $G(s)$ for this three-parameter system is obtained from the ratio of the Laplace transform of the output $\bar{y}(s)$ to that of the input $\bar{F}(s)$ as 


$$
G(s)=\frac{\bar{y}(s)}{\bar{F}(s)}
$$

where $s$ is a complex variable.

Neglecting the initial conditions, $G(s)$ becomes

$$
\begin{aligned}
G(s) & =\frac{1}{m s^{2}+c s+k} \\
& =\frac{A}{\left(s-p_{1}\right)\left(s-p_{2}\right)}
\end{aligned}
$$

where $A=\frac{1}{n}$, and

$$
\mathrm{p}_{1}, \mathrm{p}_{2}=-\frac{\mathrm{c}}{2 \mathrm{~m}} \pm \sqrt{\frac{\mathrm{c}^{2}}{2 \mathrm{~m}}-\frac{\mathrm{k}}{\mathrm{m}}}
$$

Similarly, the differential equations of motion for the seven-parameter model (Figure 2-b) are written as [55]

$$
\begin{aligned}
& m_{1} \ddot{y}_{1}(t)+c_{1} \dot{y}_{1}(t)+\left(k_{1}+k_{3}\right) y_{1}(t)-k_{3} y_{2}(t)=F(t) \\
& m_{2} \ddot{y}_{2}(t)+c_{2} \dot{y}_{2}(t)+\left(k_{2}+k_{3}\right) y_{2}(t)-k_{3} y_{1}(t)=0
\end{aligned}
$$

and the transfer function becomes

$$
\begin{aligned}
G(s) & =\frac{\bar{y}_{1}(s)}{F(s)} \\
& =\frac{A\left(s-r_{1}\right)\left(s-r_{2}\right)}{\left(s-p_{1}\right)\left(s-p_{2}\right)\left(s-p_{3}\right)\left(s-p_{4}\right)}
\end{aligned}
$$

where the constant $A$, the zeros $r_{i}$ and the poles $p_{i}$ are functions of $m_{1}, m_{2}, c_{1}, c_{2}, k_{1}, k_{2}$ and $k_{3}$. 
In general, the mathematical model from any mass-springdashpot mechanical system can be written in the form [52]

$$
G(s)=\frac{\left(s-r_{1}\right)\left(s-r_{2}\right) \cdots\left(s-r_{m}\right)}{\left(s-p_{1}\right)\left(s-p_{2}\right) \cdots\left(s-p_{n}\right)}
$$

However, the assumed mechanical model specifies the number of material paraneters obtained in the nathenatical representation.

The procedure used by Swani [56] to obtain the transfer function for asphaltic concrete presents a method where no mechanical model is assumed. The technique is based on direct frequency tests which require steady state conditions between the input and output when both vary sinusoidally with time. The anplitude and phase relationship between input and output sine waves are measured and the process is repeated throughout the frequency range of interest. The ratio of the magnitude of the output (displacement) to that of the corresponding input (force) is then plotted (in decibels) against the $\log$ of frequency to obtain the frequency spectrum. The asymptotic approximation of the frequency spectrum gave the following transfer function of the system:

$$
G(s)=\frac{A\left(s-r_{1}\right)\left(s-r_{2}\right)\left(s-r_{2}\right)}{\left(s-p_{1}\right)\left(s-p_{2}\right)\left(s-p_{3}\right)\left(s-p_{4}\right)}
$$

The study $[56,57]$ concluded that an asphaltic concrete at a constant tenperature could be uniquely represented by a transfer function; and that the coefficients in the transfer 
function were believed to be better indicators of material performance than those previously used.

The frequency response method of determining the transfer function may be impractical in cases where short testing time is necessary. Some established pavement systems, such as Interstate Highways, may not tolerate off-schedule operation for steady-state sinusoidal measurements. In the present investigation the impulse response of a pavenent system is obtained in the time domain fron a single impulse test with a duration of less than one second.

\section{Laboratory Studies of Flexible Pavements}

Literature was reviewed to provide background in selecting the pertinent factors and assigning typical values to the variables used in this study. Results of the laboratory studies of others are pertinent in this regard.

Subbaraju [58] conducted model studies of stresses in the upper layers of pavements. A 2 -inch thick asphaltic concrete slab was placed on a subgrade soil confined in a wooden box with inside dimensions $23 \frac{1}{2}$ by $25 \frac{1}{2}$ by 23 inches deep. Static loads of 650 pounds were applied through a $3 \frac{3}{4}$ - inch diameter bearing plate. Assuming the stresses for the loading used would not extend more than ten inches beyond the center loading point, no edge effect was considered. The assumption was verified by his test results. 
Monismith and Secor [41] attempted to validate viscoelastic theory by analyzing a thin viscoelastic plate on a Winkler foundation. Theoretical deflections were compared with those measured from a 40 by 40 by $1 \frac{1}{2}$ inches deep asphaltic concrete slab resting on a bed of closely spaced springs. In some instances, discrepancies, which were larger at higher test temperatures, were attributed to the assumptions made in the analysis.

To validate the discrete-element solutions for pavement slabs, Agarwol and Hudson [59] tested a simple two-1ayer model. The system used in the investigation consisted of a small aluminum slab seated on a saturated clay subgrade in a 2 by 2 by 2 -foot wooden box. Load magnitudes of 100 and 200 pounds were transmitted statically through a $\frac{1}{4}$ - inch diameter rod.

Model studies where al1 layer materials were ideally simulating [60] or actually representative [61, 62] have been conducted. Surface course horizontal dimensions ranging from 9 by 9 inches [59] to 10 by 10 feet [62] have been used.

In comparison with static tests, dynamic tests have been relatively few in number. Brown and Pel1 [63] tested a two-layer system subjected to a pulse load having an amplitude of approximately $7.6 \mathrm{kips}$ and durations of 0.1 and 2 seconds. The study confirmed that the assumptions of elastic theory are not generally valid for pavement materials 
[63]. Waterhouse [61] tested a three-1ayer test pit to failure under a repeated load of 5 tons magnitude and frequency of 8 cycles per minute. The sides of the box containing the 6 -foot square by 5 -foot deep specimen were believed to have only a slight effect upon the results [61].

Drennon and Kenis [62] considered pavements as linear systems and applied Duhamel's superposition integral to predict repetitive load displacements from static loads. The maximum load intensity applied to the full-scale asphaltic concrete pavement model was 80 psi at a frequency of one cycle per second. It was concluded from the experimental results that the total observed deflections increased linearly with load and that the dynamic components of both deflection and strain were basically linear. Some discrepancy existed between measured and predicted displacements partiy due to using only the creep curve rather than both creep and recovery curves as input to the superposition integral [62].

A promising field test to evaluate flexible pavements by impulsive loads was carried out by Isada [49, 50]. From the peak displacement and the magnitude of the impulse, a road stiffness was determined but no analysis of the displacement time data was performed.

The above review indicates that neither the classical theories (elastic or viscoelastic) nor the assumed dynamic models can adequately characterize the time-dependent response of a pavement system. It also shows that the 
transfer function theory appears to be a sufficient framework within which the time-dependent behavior of pavements can be investigated. 


\section{THEORETICAL ANALYSIS}

The basic concepts underlying the transfer function theory is presented in this section. Three areas are of major interest: general assumptions, experimental determination of the impulse response and prediction theory.

\section{Assumptions}

Transfer function theory is based on the assumption that pavements behave as deterministic systems. A relationship which exists between known input and output conditions is sought. This is in contradiction to classical theories which assume this relationship to be known initially. The system functions are schematically shown in Figure 4 . Complex dynamic situations including aircraft flight data have been synthesized utilizing the assumption that a determinable function relates the output to the input $[51,52,55]$.

Furthermore, it is assumed that pavements will behave as linear systems. Although at high magnitudes of stresses and temperatures non-1inearity may be observed, the investigations reported by Heukelom [45], Drennon and Kenis [62] and others $[47,48,61]$ have shown that the assumption holds for small deflections normally experienced by pavement systems. The AASHO Road Test results, where single as well 

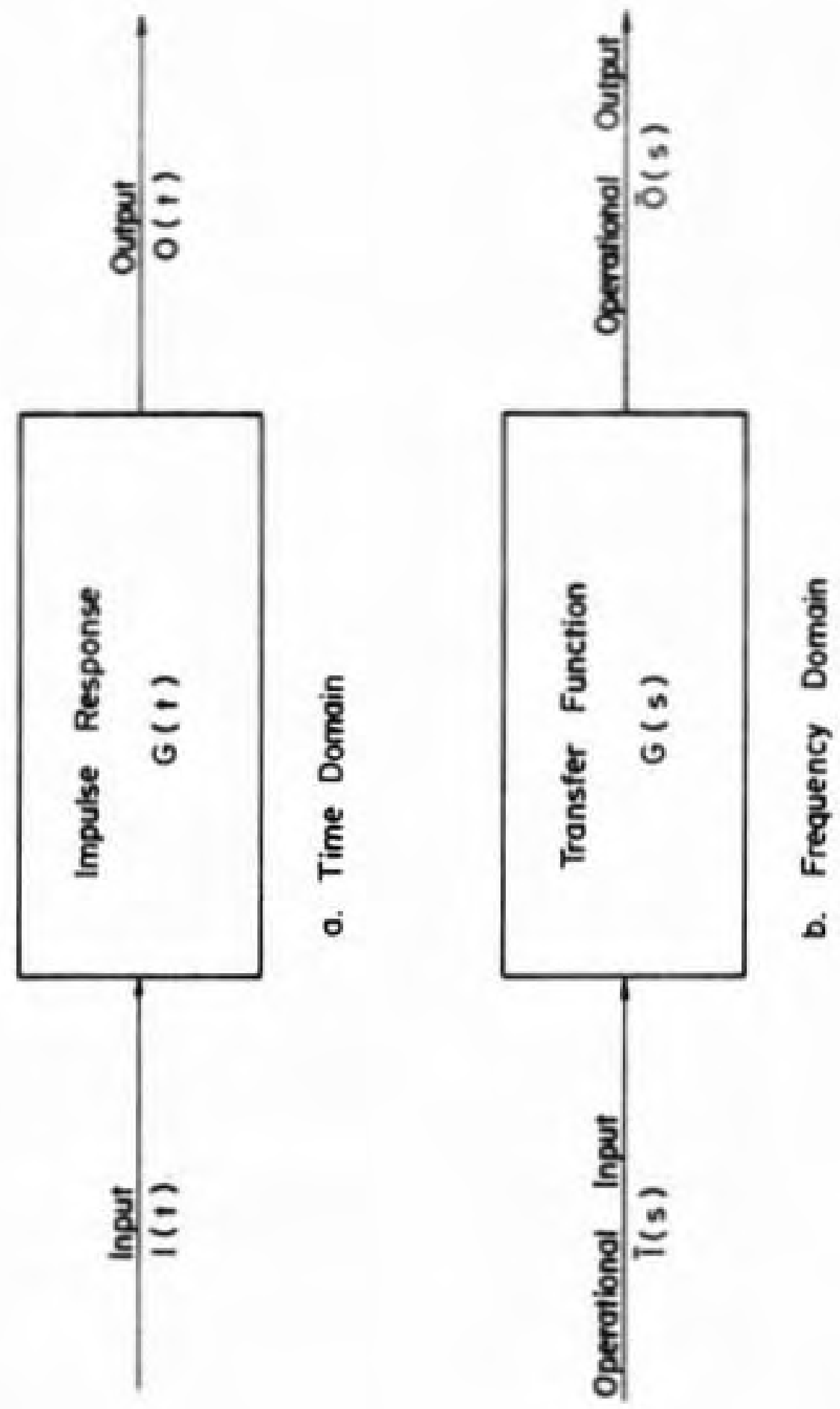

$\frac{0}{\frac{1}{2}}$

$\underset{\frac{1}{n}}{\frac{5}{n}}$

$\frac{1}{1}$

ㄴ

을

峁

$\frac{5}{\frac{4}{2}}$ 
as tandem axle loads were employed, indicated that creep speed deflections were linear in most cases [3, pp. 102-103].

\section{Experimental Determination of the Impulse Response}

With reference to Figure 4, a dynamic system can be represented by a transfer function $G(s)$ defined as the ratio of the Laplace transform of the output $O(t)$ to the Laplace transform of the input $1(t)$. By this definition,

or

$$
\begin{aligned}
& G(s)=\frac{\delta(s)}{I(s)} \\
& \bar{O}(s)=G(s) I(s)
\end{aligned}
$$

$$
\text { where } \begin{aligned}
\bar{O}(s) & =L[O(t)] \\
I(s) & =L[I(t)] \\
s & =\text { Laplace transform parameter, } \\
t & =\text { time, and } \\
L & =\text { Laplace transformation }
\end{aligned}
$$

The inverse transform of $G(s)$ is

$$
G(t)=L^{-1}[G(s)]
$$

where $\mathrm{L}^{-1}$ is the inverse Laplace transformation.

The function $G(t)$ is determined solely by the system parameters and is called the impulse response or the response function of the system. The operational form of Equation 9 can be expressed in the time domain using Borel's theorem on the convolution of two functions [54] to obtain the output 


$$
O(t)=\int_{0}^{t} G(\tau) I(t-\tau) d \tau
$$

$G(t)$ is obtained implicitly by the finite difference method [64] as

$$
G\left(t_{k}\right)=\frac{O\left(t_{k}\right)-\sum_{j=1}^{k} G\left(t_{j}\right) I\left(t_{k-j+1}\right) \Delta t}{K F p \Delta t}
$$

where $G\left(t_{k}\right)=$ the vector quantity of the response function

$$
\begin{aligned}
& \text { at time } t_{k}, \\
O\left(t_{k}\right) & =\text { the value of the output at } t_{k}, \\
I\left(t_{k}\right) & =\text { the value of the input at } t_{k}, \\
K & =\text { conversion factor, } \\
F_{p} & =\text { the peak value of the input, and } \\
\Delta t & =\text { time interval. }
\end{aligned}
$$

The denominator in Equation 13 may be too small for Equation 13 to converge. If this is the case, as was found to be generally true in the present investigation, $K$ is chosen such that the response function is within the conversion region. In this study, a denominator value of 9 or more would cause Equation 13 to converge. The $K$ factor was taken to be 10 for faster convergence.

The experimental basis discussed here to obtain the response function is the impulse test. An impulse load input of known peak value is applied for a very short time duration to the system whose response function is sought. Both the impulse input force and the output deflections are 
recorded as functions of time. Figure 5 shows schematic traces of the input and the output necessary to determine such a response function in conjunction with Equation 13 . The computation results in vector quantities of the response function. These values, shich are spaced $\Delta t$ apart in the time domain, can then be approximated by a mathematical function using a non-linear least square curve fit method. The closer the approximation to the actual response function curve, the better becomes the approximation of the response function sought. The function used in this investigation is

$$
G(t)=\alpha e^{-B t} \sin \gamma t
$$

where $G(t)$ = response function,

$$
\mathrm{t}=\mathrm{time} \text {, and }
$$

$\alpha, \beta$ and $\gamma$ are constants.

As a check on the response functions prior to curve fitting, the finite difference solution of Equation 12 was obtained explicitly [64] as

$$
O\left(t_{k}\right)=\sum_{j=1}^{k} G\left(t_{j}\right) I\left(t_{k-j+1}\right) \Delta t
$$

Thus, the output calculated from Equation 15 should match the measured output used to obtain the response function.

The modified version of the computer program [64] used to calculate the response functions and to predict the output is shown in Appendix A. Subroutines CONVLI and CONVLE were employed to solve, respectively, Equation 13 and Equation 15. 


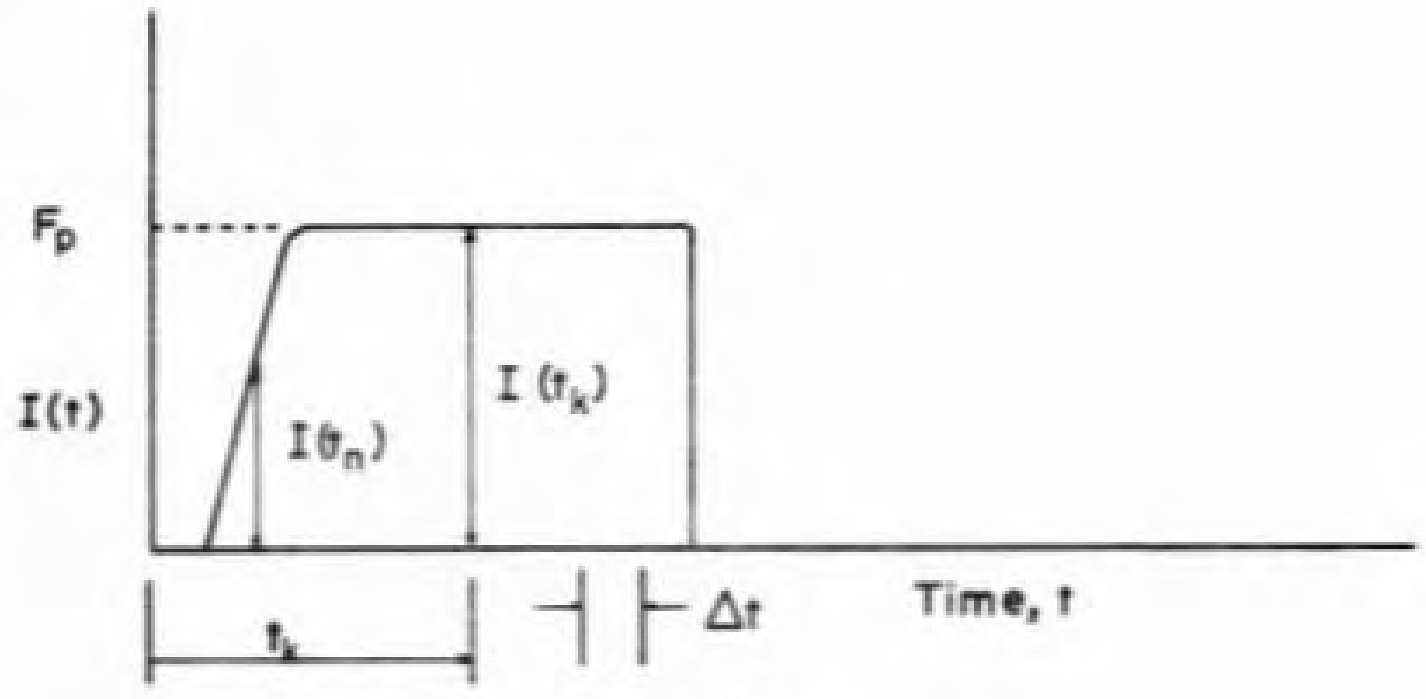

a. Inout

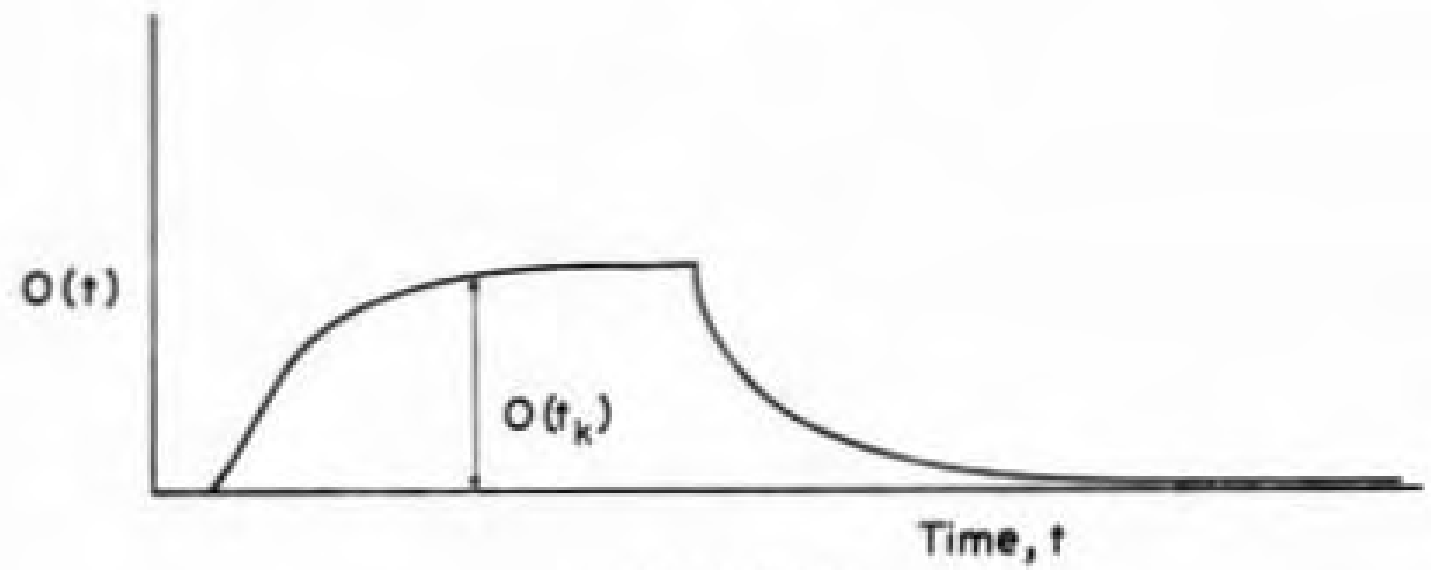

b. Output

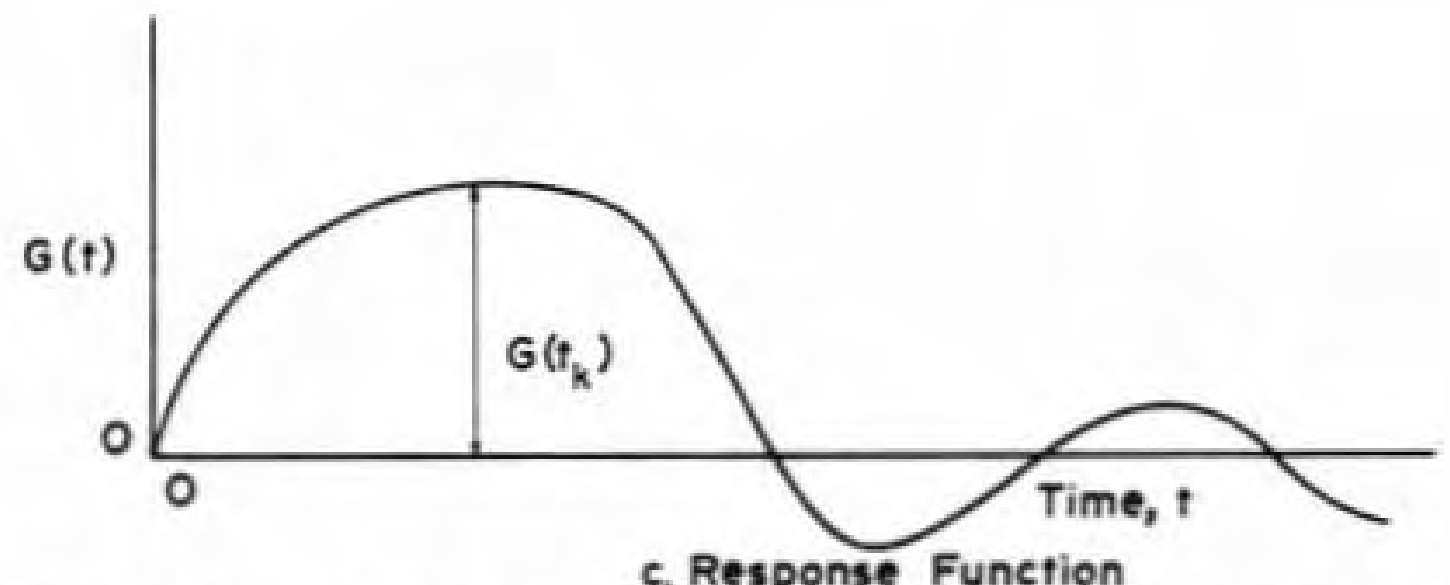

FIGURE 5 EXPERIMENTAL DETERMINATION OF SYSTEM RESPONSE FUNCTION 


\section{Prediction Theory}

If the system represented by Equation 9 (or Equation 14) is subjected to an excitation force $F(t)$ and the corresponding output time function is $y(t)$, the transformed response is

$$
\bar{y}(s)=G(s) \bar{F}(s)
$$

By the convolution theorem,

$$
\begin{aligned}
y(t) & =L^{-1}[G(s) \bar{F}(s)] \\
& =G(t) * F(t) \\
& =\int_{0}^{t} G(\tau) F(t-\tau) d \tau
\end{aligned}
$$

Equation 17 illustrates that one can calculate the system response to any excitation function $F(t)$ if the response function $G(t)$ is known. When the input function has a mathematical representation, the convolution Equation 17 can be solved analytically. The solutions for a step load input and a repeated load input are derived below for a pavement system whose response function is $G(t)$.

\section{Solution for Step Loading}

Consider the step function input $F(t)$ defined as

$$
\begin{array}{ll}
F(t)=0 & \text { for } t<0 \\
F(t)=F_{0} & \text { for } t \geq 0
\end{array}
$$

where $F_{0}$ is the magnitude of the static compressive force. However, due to the introduction of the conversion factor $K$ 
in obtaining the response functions, Equation 18 has to be modified as

$$
\begin{array}{ll}
F(t)=0 & \text { for } t<0 \\
F(t)=K F_{0} & \text { for } 0 \leq t \leq t_{n} \\
F(t)=F_{0} & \text { for } t>t_{n}
\end{array}
$$

where $t_{n}$ is the time at which the input, from which the response function is obtained, first becomes non-zero. Substituting Equations 14 and 19 into Equation 17 ,

$$
\begin{aligned}
y(t)= & K F_{0} \int_{0}^{t} n \alpha e^{-\beta \tau} \sin \gamma \tau d \tau+F_{0} \int_{t_{n}}^{t} \alpha e^{-\beta \tau} \sin \gamma \tau d \tau \\
= & F_{0} \alpha\left[\frac{K \gamma}{\beta^{2}+\gamma^{2}}-\frac{(K-1)}{\sqrt{\beta^{2}+\gamma^{2}}} e^{-\beta t_{n}} \sin \left(\gamma t_{n}+\phi\right)\right. \\
& \left.-\frac{e^{-\beta t}}{\sqrt{B^{2}+\gamma^{2}}} \sin (\gamma t+\phi)\right]
\end{aligned}
$$

For $t<t_{n}$,

$$
\begin{aligned}
y(t) & =K F_{0} \int_{0}^{t} \alpha e^{-\beta \tau} \sin \gamma \tau d_{\tau} \\
& =K F_{0} \alpha\left[\frac{\gamma}{\beta^{2}+\gamma^{2}}-\frac{e^{-\beta t}}{\sqrt{\beta^{2}+\gamma^{2}}} \sin (\gamma t+\phi)\right]
\end{aligned}
$$

where $\phi=\tan ^{-1}(\gamma / B)$

At $t=0$, Equation 20a yields:

$$
y(0)=0
$$

As $\mathrm{t}$ becomes large, the steady-state response is obtained from Equation 20 as 


$$
y(t)=F_{0} \alpha\left[\frac{K \gamma}{\beta^{2}+\gamma^{2}}-\frac{(K-1)}{\sqrt{\beta^{2}+\gamma^{2}}} e^{-\beta t_{n}} \sin \left(\gamma t_{n}+\phi\right)\right]
$$

The computer program STALOD to solve Equation 23 is given in Appendix B.

\section{Solution for Repeated Loading}

With the modification discussed in the previous section taken into account, a haversine repeated load configuration shown in Figure 6 is defined as

$$
\begin{array}{ll}
F(t)=0 & \text { for } t<0 \\
F(t)=\frac{K F_{0}}{2}(1-\cos \omega t) & \text { for } 0 \leq t \leq t_{n} \\
F(t)=\frac{F_{0}}{2}(1-\cos \omega t) & \text { for } t>t_{n}
\end{array}
$$

where $\omega=2 \pi / p$, in which $p=$ period of loading.

Substituting Equations 14 and 24 into Equation 17,

$$
\begin{aligned}
y(t)= & \frac{K F_{0}}{2} \int_{0}^{t} \alpha e^{-\beta \tau} \sin \gamma \tau(1-\cos \omega(t-\tau)) d \tau \\
& +\frac{F_{0}}{2} \int_{t_{n}}^{t} \alpha e^{-\beta \tau} \sin \gamma \tau(1-\cos \omega(t-\tau)) d \tau \\
= & \frac{F_{0} \alpha}{2}\left[\frac{K \gamma}{\beta^{2}+\gamma^{2}}-\frac{(K-1)}{\sqrt{\beta^{2}+\gamma^{2}}} e^{-\beta t} \sin \left(\gamma t_{n}+\phi\right)\right. \\
& \left.-\frac{e^{-\beta t}}{\sqrt{B^{2}+\gamma^{2}}} \sin (\gamma t+\phi)\right] \\
& -\frac{F_{0} \alpha}{4} \cos \omega t\left\{K\left[\frac{(\gamma-\omega)}{\beta^{2}+(\gamma-\omega)^{2}}+\frac{(\gamma+\omega)}{B^{2}+(\gamma+\omega)^{2}}\right]\right.
\end{aligned}
$$




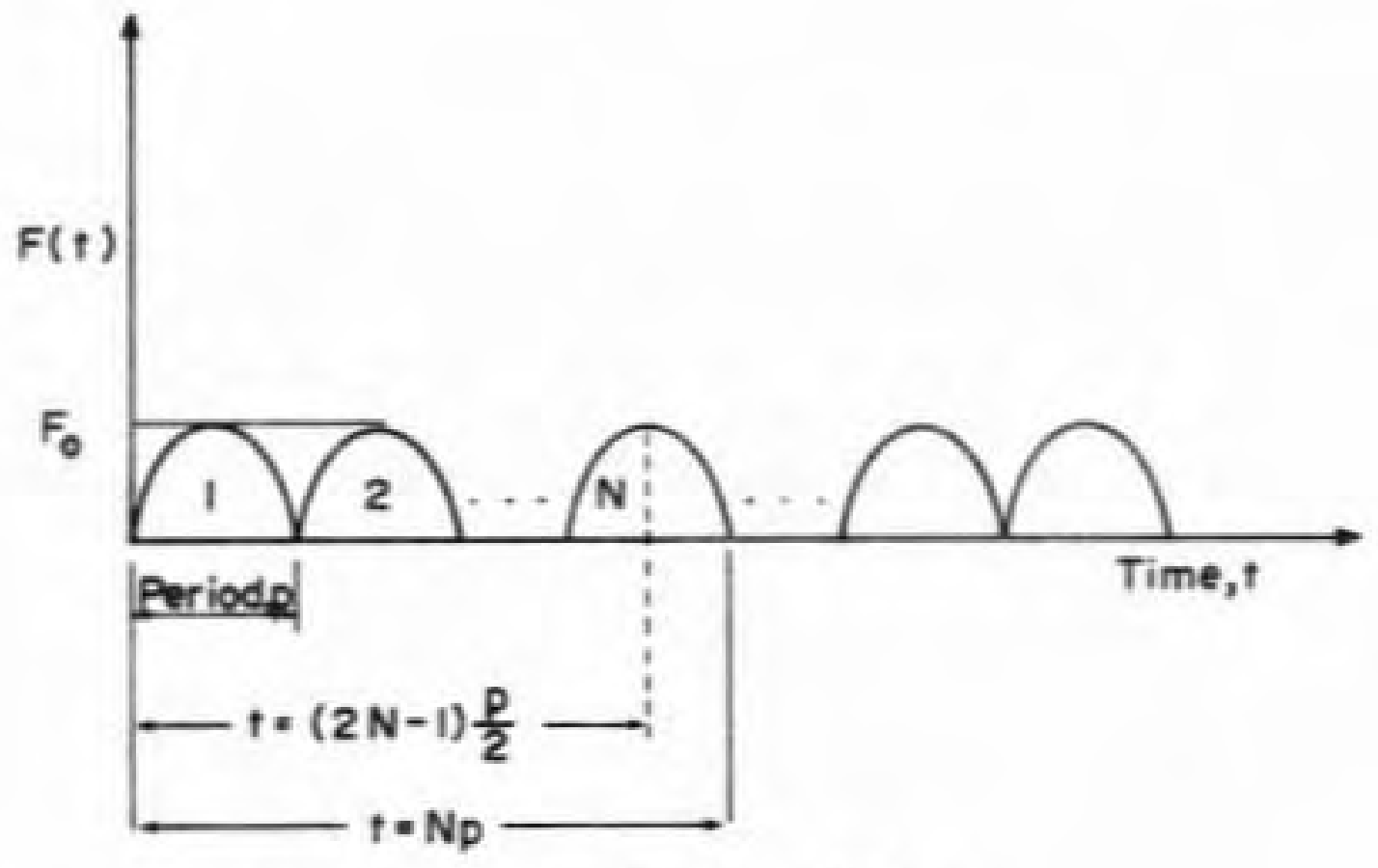

a. Input: $F(t)=\frac{F_{0}}{2}\left(1-\cos \frac{2 \pi}{p} t\right)$

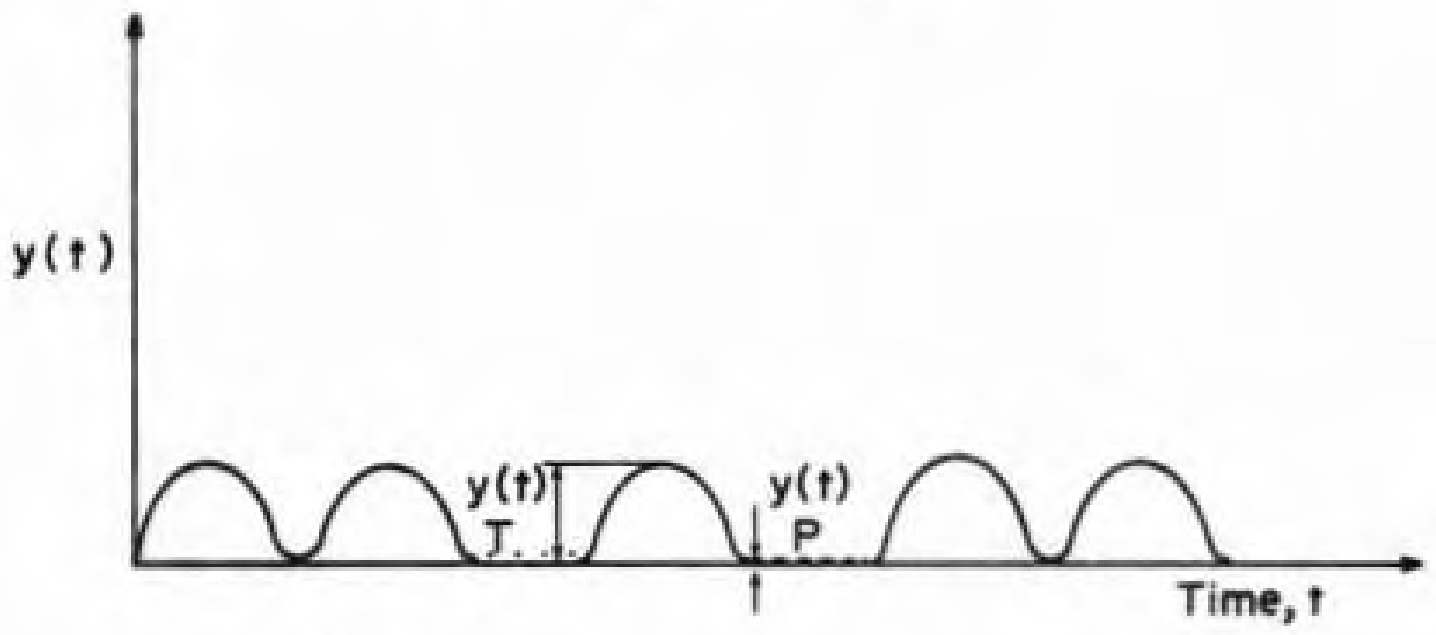

b. Output

FIGURE 6 HAVERSINE INPUT AND OUTPUT FUNCTIONS 


$$
\begin{aligned}
& -(K-1)\left[\frac{e^{-\beta t_{n}}}{\sqrt{B^{2}+(\gamma-\omega)^{2}}} \sin \left((\gamma-\omega) t_{n}+\phi_{1}\right)\right. \\
& \left.+\frac{e^{-\beta t_{n}}}{\sqrt{B^{2}+(\gamma+\omega)^{2}}} \sin \left((\gamma+\omega) t_{n}+\phi_{2}\right)\right] \\
& -\frac{e^{-B t}}{\sqrt{B^{2}+(\gamma-\omega)^{2}}} \sin \left((\gamma-\omega) t+\phi_{1}\right) \\
& \left.-\frac{e^{-B t}}{\sqrt{B^{2}+(\gamma+\omega)^{2}}} \sin \left((\gamma+\omega) t+\phi_{2}\right)\right\} \\
& \text { - } \frac{F_{0} \alpha}{4} \sin \omega t\left\{K\left[\frac{B}{B^{2}+(\gamma-\omega)^{2}}-\frac{B}{B^{2}+(\gamma+\omega)^{2}}\right]\right. \\
& -(K-1)\left[\frac{e^{-\beta t_{n}}}{\sqrt{\beta^{2}+(\gamma-\omega)^{2}}} \cos \left((\gamma-\omega) t_{n}+\phi_{1}\right)\right. \\
& \left.-\frac{e^{-\beta t_{n}}}{\sqrt{B^{2}+(\gamma+\omega)^{2}}} \cos \left((\gamma+\omega) t_{n}+\phi_{2}\right)\right] \\
& -\frac{e^{-B t}}{\sqrt{B^{2}+(\gamma-\omega)^{2}}} \cos \left((\gamma-\omega) t+\phi_{2}\right) \\
& \left.-\frac{e^{-B t}}{\sqrt{B^{2}+(\gamma+\omega)^{2}}} \cos \left((\gamma+\omega) t+\phi_{2}\right)\right\}
\end{aligned}
$$

where $\phi=\tan ^{-1}(\gamma / B)$,

$$
\begin{aligned}
& \phi_{1}=\tan ^{-1}\left(\frac{\gamma-\omega}{\beta}\right), \text { and } \\
& \phi_{2}=\tan ^{-1}\left(\frac{\gamma+\omega}{\beta}\right) .
\end{aligned}
$$

Total Response. The total response $y_{T}(t)$ of the system is evaluated when a load cycle is at its peak position (Figure 6), that is when 


$$
t=(2 N-1) \frac{\mathrm{R}}{2}
$$

where $t=t i m e$,

$$
\begin{aligned}
& N=\text { number of load applications, and } \\
& P=\text { period of loading. }
\end{aligned}
$$

Since $\sin \omega t=\sin \left(\frac{2 \pi}{\mathrm{P}}(2 \mathrm{~N}-1) \frac{\mathrm{P}}{2}\right)=0$,

and $\cos \omega t=\cos \left(\frac{2 \pi}{\mathrm{P}}(2 \mathrm{~N}-1) \frac{\mathrm{P}}{2}\right)=-1$,

Equation 26 reduces to

$$
\begin{aligned}
y_{T}(t)= & \frac{F_{0} a}{2}\left\{\frac{K \gamma}{B^{2}+\gamma^{2}}+\frac{K}{2}\left[\frac{\gamma-\omega}{B^{2}+(\gamma-\omega)^{2}}+\frac{\gamma+\omega}{B^{2}+(\gamma+\omega)^{2}}\right]\right. \\
& -\frac{(K-1)}{\sqrt{B^{2}+\gamma^{2}}} e^{-B t_{n}} \sin \left(\gamma t_{n}+\phi\right) \\
& -\left(\frac{K-1}{2}\right)\left[\frac{e^{-\beta t_{n}}}{\sqrt{B^{2}+(\gamma-\omega)^{2}}} \sin \left((\gamma-\omega) t_{n}+\phi_{1}\right]\right. \\
& \left.+\frac{e^{-\beta t_{n}}}{\sqrt{B^{2}+(\gamma+\omega)^{2}}} \sin \left((\gamma+\omega) t_{n}+\phi_{2}\right)\right] \\
& -\frac{e^{-\beta t}}{\sqrt{B^{2}+\gamma^{2}}} \sin (\gamma t+\phi) \\
& -\frac{1}{2}\left[\frac{e^{-\beta t}}{\sqrt{B^{2}+(\gamma-\omega)^{2}}} \sin \left((\gamma-\omega) t+\phi_{1}\right)\right. \\
& \left.\left.+\frac{e^{-\beta t}}{\sqrt{B^{2}+(\gamma+\omega)^{2}}} \sin \left((\gamma+\omega) t+\phi_{2}\right)\right]\right\}
\end{aligned}
$$


Permanent or Accumulative Response. The permanent response $y_{p}(t)$ is measured at the end of a load cycle (Figure 6), that is when

$$
t=N p
$$

Since $\sin \omega t=\sin \left[\frac{2 \pi}{\mathrm{p}} \mathrm{Np}\right]=0$

and $\quad \cos \omega t=\cos \left(\frac{2 \pi}{p} \mathrm{~Np}\right)=1$,

Equation 26 yields

$$
\begin{aligned}
y_{p}(t)= & \frac{F_{0} \alpha}{2}\left\{\frac{K \gamma}{B^{2}+\gamma^{2}}-\frac{K}{2}\left[\frac{\gamma-\omega}{B^{2}+(\gamma-\omega)^{2}}+\frac{\gamma+\omega}{B^{2}+(\gamma+\omega)^{2}}\right]\right. \\
& -\frac{(K-1)}{\sqrt{B^{2}+\gamma^{2}}} e^{-B t_{n}} \sin \left(\gamma t_{n}+\phi\right) \\
& +\left(\frac{K-1}{2}\right)\left[\frac{e^{-B t} n}{\sqrt{B^{2}+(\gamma-\omega)^{2}}} \sin \left((\gamma-\omega) t_{n}+\phi_{1}\right)\right. \\
& \left.+\frac{e^{-B t} n}{\sqrt{B^{2}+(\gamma+\omega)^{2}}} \sin \left[(\gamma+\omega) t_{n}+\phi_{2}\right)\right] \\
& +\frac{e^{-B t}}{\sqrt{B^{2}+\gamma^{2}}} \sin (\gamma t+\phi) \\
& +\frac{1}{2}\left[\frac{e^{-B t}}{\sqrt{B^{2}+(\gamma-\omega)^{2}}} \sin \left((\gamma-\omega) t+\phi_{1}\right)\right. \\
& \left.\left.+\frac{e^{-B t}}{\sqrt{B^{2}+(\gamma+\omega)^{2}}} \sin \left[(\gamma+\omega) t+\phi_{2}\right)\right]\right\}
\end{aligned}
$$

Appendix C presents the computer progran REPLOD to solve Equations 28 and 30 . 


\section{EXPERIMENTAL INVESTIGATION}

The experimental phase of the study was undertaken to investigate the theory of pavement behavior developed in the preceding section. The scope of the investigation, materials selected, design and preparation of the pavement models, instrumentation and test procedures are described.

\section{$\underline{\text { Scope }}$}

The study was limited to controlled laboratory testing of three-layer flexible model pavements constructed of representative paving materials. A silty sand subgrade, a crushed aggregate base, and an asphalt concrete surface were the components of the three-layer systems. Surface course thicknesses of 1 and 2 inches were used. The $3 \frac{1}{2}$-inch base course thickness was estimated by an approximate design procedure briefly outlined in the next subsection. The use of an asphalt-treated base and a 3 -inch surface course thickness originally planned to be considered were deleted because the first case amounts to increasing the surface course thickness over the untreated base $[3,60]$, while in the latter case, only the response of the top layers would have been measured. 
Static loads and two dynamic loads, namely, impulse and cyclic loadings were thought to simulate the loading conditions which occur in a prototype pavement. Contact pressures of $14.93,29.86$ and 59.72 psi were applied over a circular loaded area of 4-inch diameter at the center of the pavements. These stress magnitudes were considered representative of those encountered in highway pavements by vehicle wheels. The loading plate used was chosen to be small relative to the pavement surface, but yet to allow a sufficient portion of the subgrade to be stressed. The tests were carried out under isothermal conditions in a constant temperature room at 50,75 and $100^{\circ} \mathrm{F}$.

The mode 1 pavement with 2 -inch surfacing was also subjected to corner loadings to study the edge effects that might result as a consequence of the sides of the box. Loading modes were impulse and cyclic. The test temperature was $50^{\circ} \mathrm{F}$ for the corner loadings since any edge effects would be more pronounced, if any were to be significant, at these test conditions. Only the largest stress magnitude, namely, $59.72 \mathrm{psi}$ was applied over the 4-inch diameter plate for the edge loading condition.

Approximate Design of the Model Pavements

Influence curves developed by Nijboer [65], from the three-layer elastic analysis presented by Jones [13], in conjunction with the equivalent layer theory [66], were used for the purpose of estimating the thickness of the 
base course. A brief outline of the procedure follows:

1. From data given by Yoder [6], the elastic moduli $E_{3}=2,500$ psi and $E_{2}=5,000$ psi, were obtained for the subgrade and the base course, respectively. The corresponding value for the surface mixture was $E_{1}=40,000$ psi $[15,57]$.

2. With a liniting deflection of 0.025 in. [67, 68], an applied pressure of 80 psi, a radius of contact area of 2 in., the influence curve [65, Graph IV] yields a thickness of 2.7 in. of asphaltic concrete over the subgrade.

3. A one-inch surface was thought reasonable.

4. The renaining $1.7 \mathrm{in}$. multiplied by the approxinate surface course/base course equivalency of $\sqrt[3]{\frac{E_{1}}{E_{2}}}=2$ gave, upon rounding to the nearest half-inch, $3 \hat{i}$ in. of base course.

Materials and Preparation of Model Pavements

The model pavements were contained in a wooden box reinforced with steel angles. Since the interest was in testing the pavement models inside a constant temperature room, the maximum possible size of the box adopted had the internal dimensions $32 \frac{1}{2}$ by $32 \frac{1}{2}$ by $23 t$ inches deep. To minimize moisture losses, the box was made of exterior type plywood and the interior sides and bottom of the box were coated with spar varnish diluted with linseed oil.

The next three sections present the results of tests performed on each of the materials, followed by a description of placing the respective naterial in the box. 


\section{Subgrade Soil}

A silty sand was used for the subgrade. Table 1 summarizes the physical properties and Figure 7 shows the grain size distribution curve of the sand. Compaction test results are given in Figure 8 .

The soil was stored in air-tight bags at its natural moisture content of 19.1 percent. A sufficient amount of soil to make a compacted lift of about one inch was then spread out in large trays. The clods were broken by hand and the soil was mixed frequently to insure uniform drying. Periodically, the moisture content was determined using a Speedy Moisture Tester, shown in Figure 9, which was precalibrated for this particular soil (Figure 10). When the moisture content was about 0.5 percent above the optimum, the soil was placed in the box in a predetermined amount necessary per $1 \mathrm{ift}$. The soil was then compacted in the box using an air hammer, weighing 14 pounds, with a 3 -inch diameter base. The air supply was set at 75 psi. Compaction at the edges and leveling were achieved by a hand tamp weighing 16 pounds and with a base plate 8 inches square. Figure 11 shows the compaction process. Marked lines on the interior of the box sides indicated when the required compaction was obtained as calculated from Equation 31:

$$
\gamma_{\text {wet }}=\frac{\mathrm{CW}}{\mathrm{h}}
$$


TABLE 1

PHYSICAL PROPERTIES OF THE SUBGRADE SOIL

Classification, Unified System ......... SM

Liquid Limit, ${ }^{1}$ \& $\ldots \ldots \ldots .3$

Plastic Limit, ${ }^{2}$ \& ........... 23.3

Plasticity Index, ${ }^{2} \& \ldots \ldots .0$

Optimum Moisture Content, ${ }^{3}$ … . . 13.7

Optimum Dry Density, ${ }^{3}$ 1bs./ft ${ }^{3} \ldots \ldots+\ldots .4$

Specific Gravity $\ldots \ldots 2.73$

Soaked CBR (California Bearing Ratio), ${ }^{5}$ \& - 10.0

1 AASHO T 89

2 AASHO T 90

3 AASHO T 99

4 AASHO T 100

S. AASHO T 193 


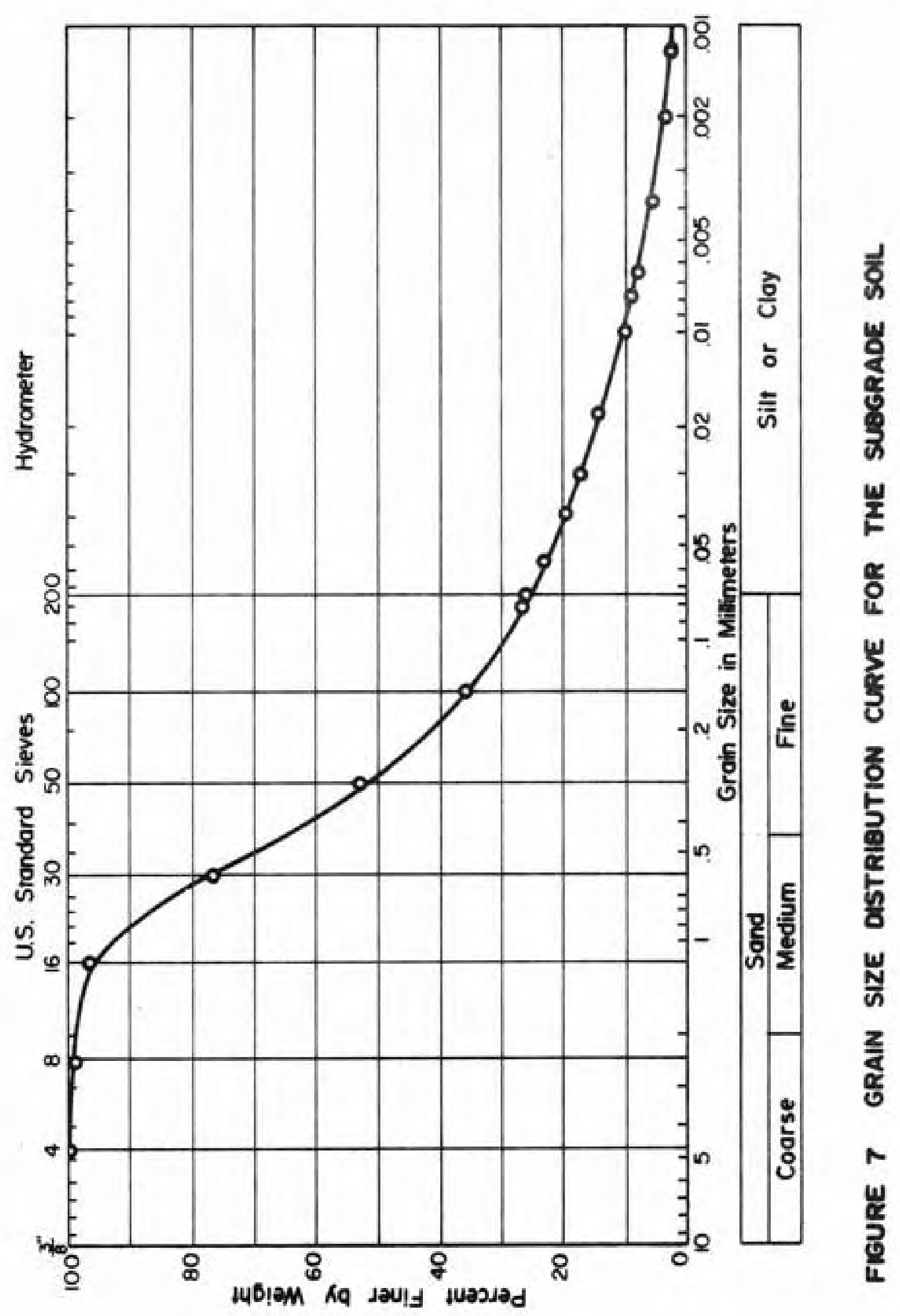




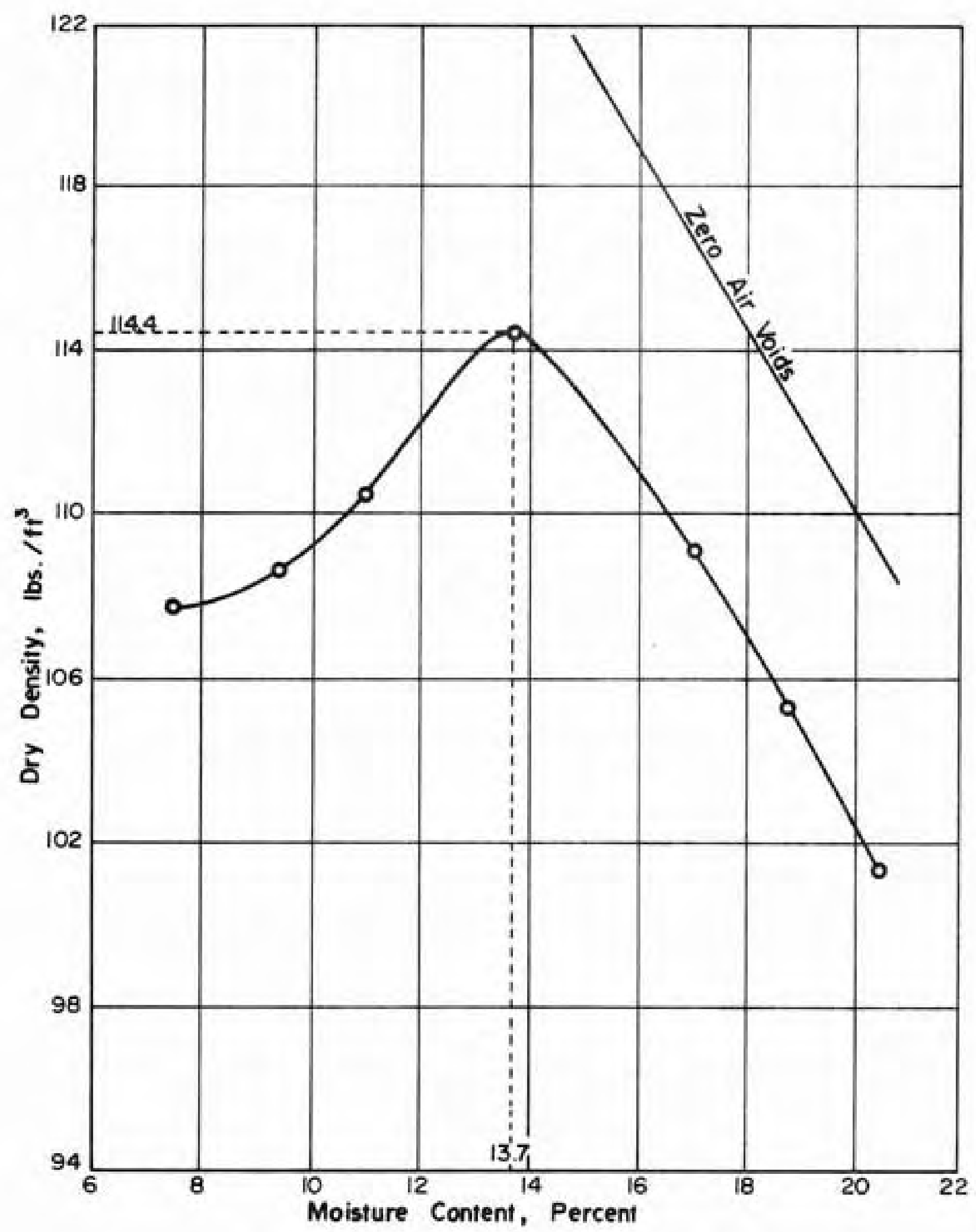

FIGURE 8 MOISTURE-DENSITY RELATIONSHIP OF THE SUBGRADE SOIL 


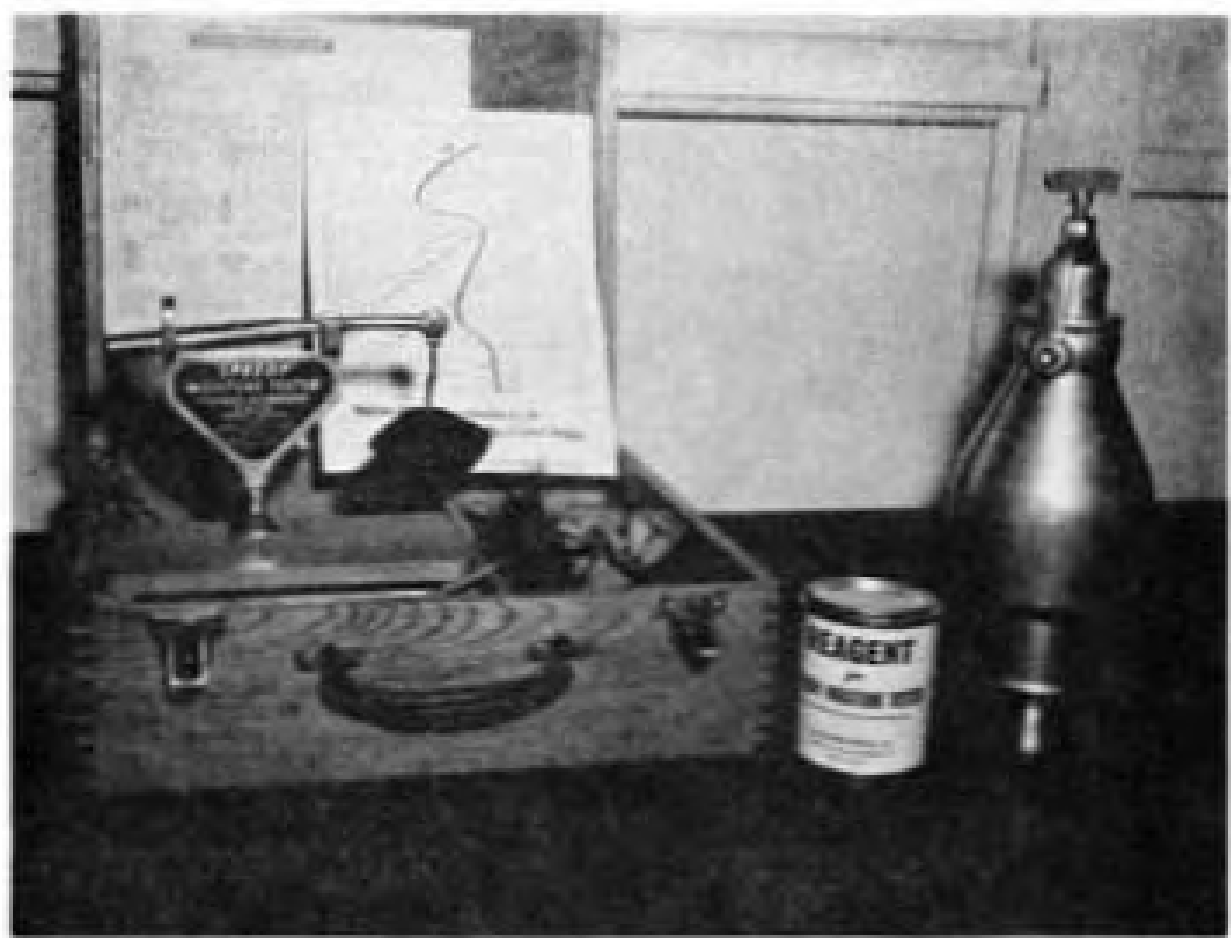

FIGURE 9 THE SPEEDY MOISTURE TESTER 


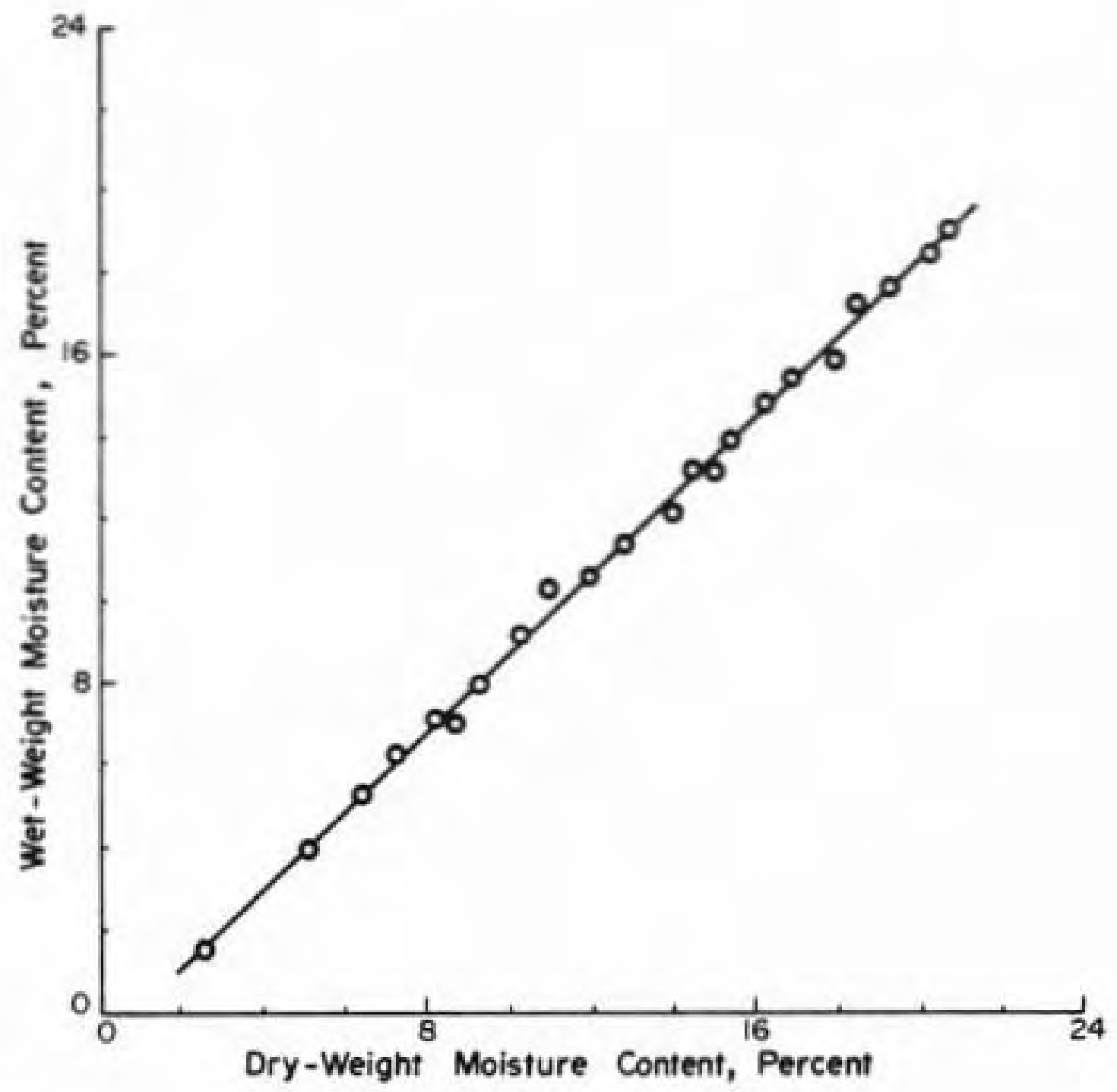

FIGURE IO CALIBRATION OF THE SPEEOY MOISTURE TESTER FOR THE SUBGRADE SOIL 

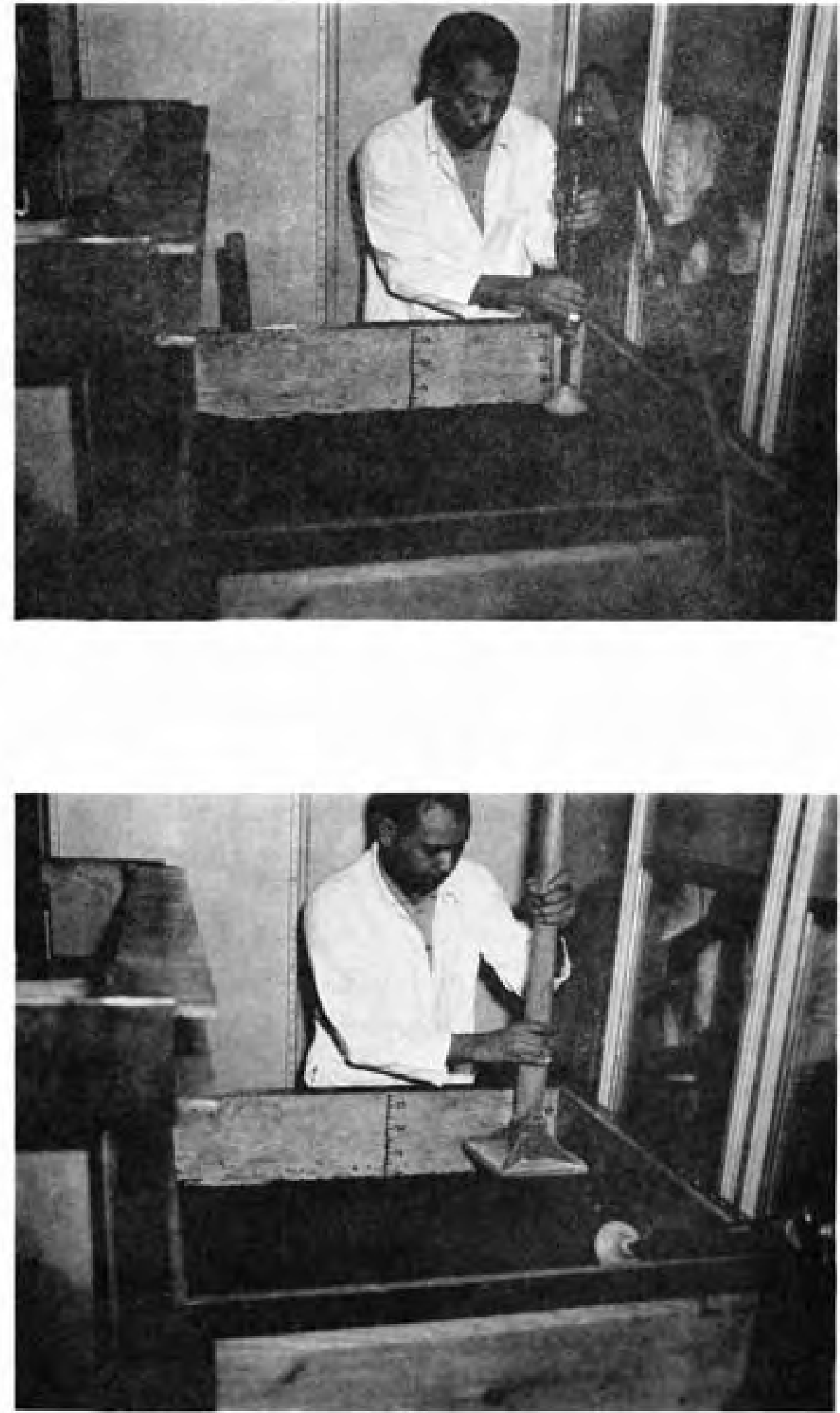

FIGURE II SUBGRADE SOIL UNDER COMPACTION 
where $\gamma_{\text {wet }}=$ wet density of soil in $1 \mathrm{bs} . / \mathrm{ft}^{3}$,

$W=$ weight of soil layer in pounds,

$\mathrm{h}=$ compacted thickness of layer in inches.

The constant $\mathrm{C}$ was calculated from the geometry of the box to be 1.64 .

Before placing each subsequent layer, the smooth surface of the compacted soil in the box was scarified to minimize compaction planes. When a compacted thickness of about 4 inches was obtained, in-situ density was checked by the sandcone method (AASHO T 191). Samples were taken at each inplace density test for water content determination.

The subgrade compaction was completed in 20 layers to

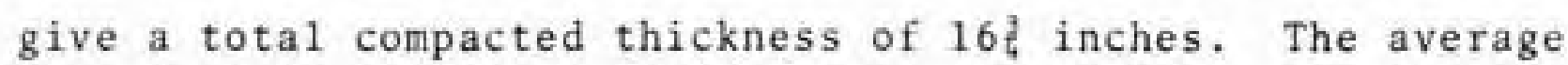
dry density of the compacted lifts was $115.51 \mathrm{bs}$. per cu. ft. which was $101 \%$ of the standard AASHO T 99. The moisture content averaged 13.98 .

\section{Base Course}

The material selected for the base course was a crushed limestone aggregate conforming with Indiana specification Size No. 53 (Figure 12). Tests performed according to AASHO T 99 and AASHO T 193 gave, respectively, an optimum density of $126.4 \mathrm{lbs} . / \mathrm{ft}^{3}$ at an optimum moisture content of $6.2 \%$, and a soaked CBR of 51.3 percent.

The aggregate was compacted to the total of $3 \frac{1}{2}$ inches thick, in three lifts, with the same air hammer used for the subgrade. However, for the base course, the circular base 


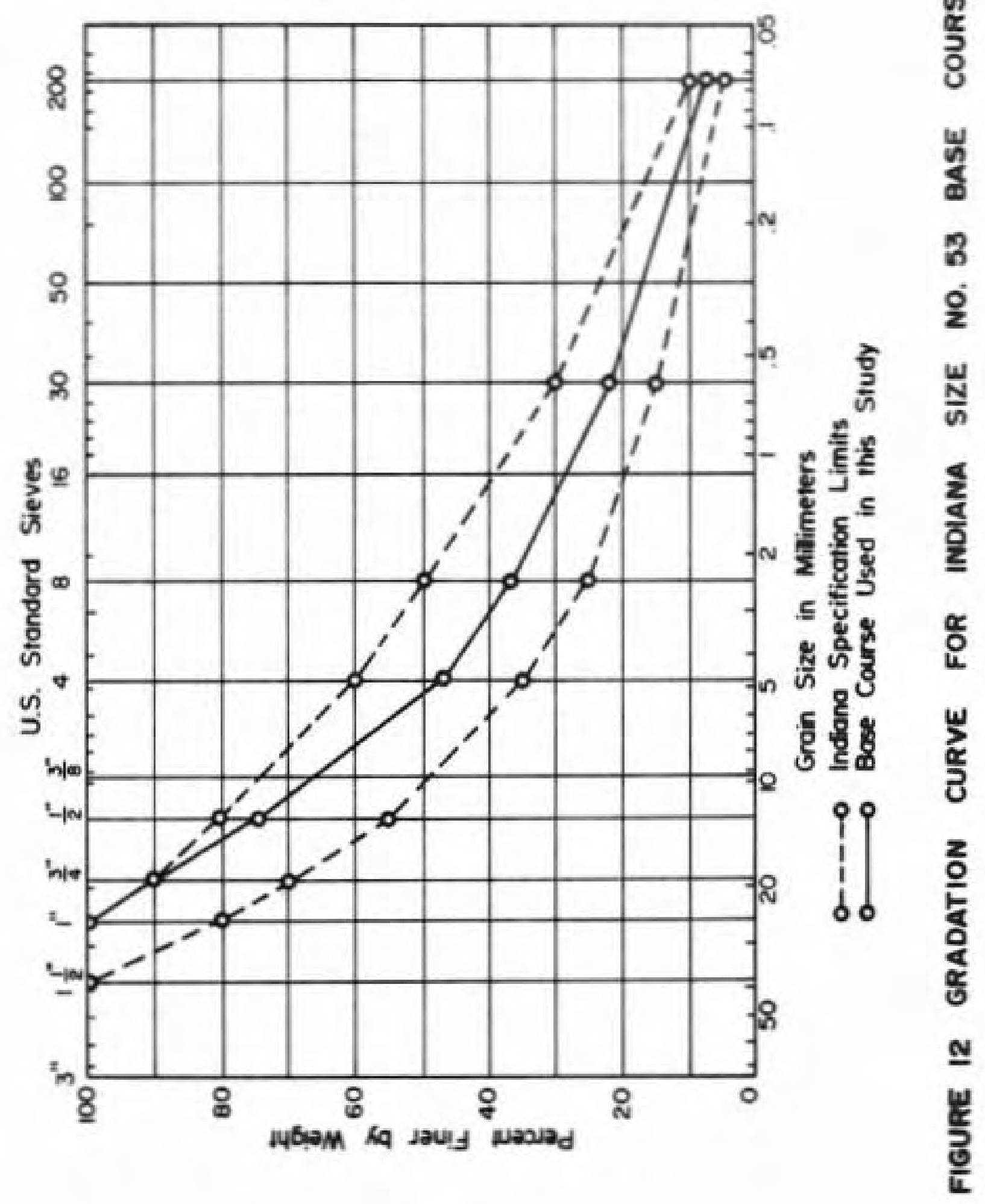


plate of the hammer was replaced with a $3 \frac{1}{2}$-inch square one. Leveling of the surface was accomplished by a vibrator. A 6 -inch by 3 -inch base plate attached to the vibrator served as a leveling foot. Both the air hamer and the vibrator were operated at a 1 ine pressure of $75 \mathrm{psi}$. The base course was compacted to $100 \%$ of the maximum dry density (AASHO T 99) as controlled by Equation 31.

\section{Surface Course}

The bituminous mixture used for the surface course was prepared from crushed limestone and sand aggregate blended to conform with Indiana type B surface mixture gradation, Sieve analysis and origin of the aggregate are given in Table 2. Figure 13 shows the gradation range for Indiana Type B Surface Mixtures and the gradation chosen for this investigation.

A 60-70 penetration asphalt cement having the properties shown in Table 3 was used for the surface course. The weight of asphalt cement mixed with the aggregate was 6 percent by weight of aggregate in accordance with Indiana specifications.* Specimens were made and tested according to the Hveem method of mix design [69]. The Hveem test results are summarized below:

* In the specifications, the range of asphalt content for Type B Surface Mixture is $5.5-6.68$ by weight of mix. 
TABLE 2

SIEVE ANALYSIS OF AGGREGATES FOR

THE SURFACE COURSE MIXTURE

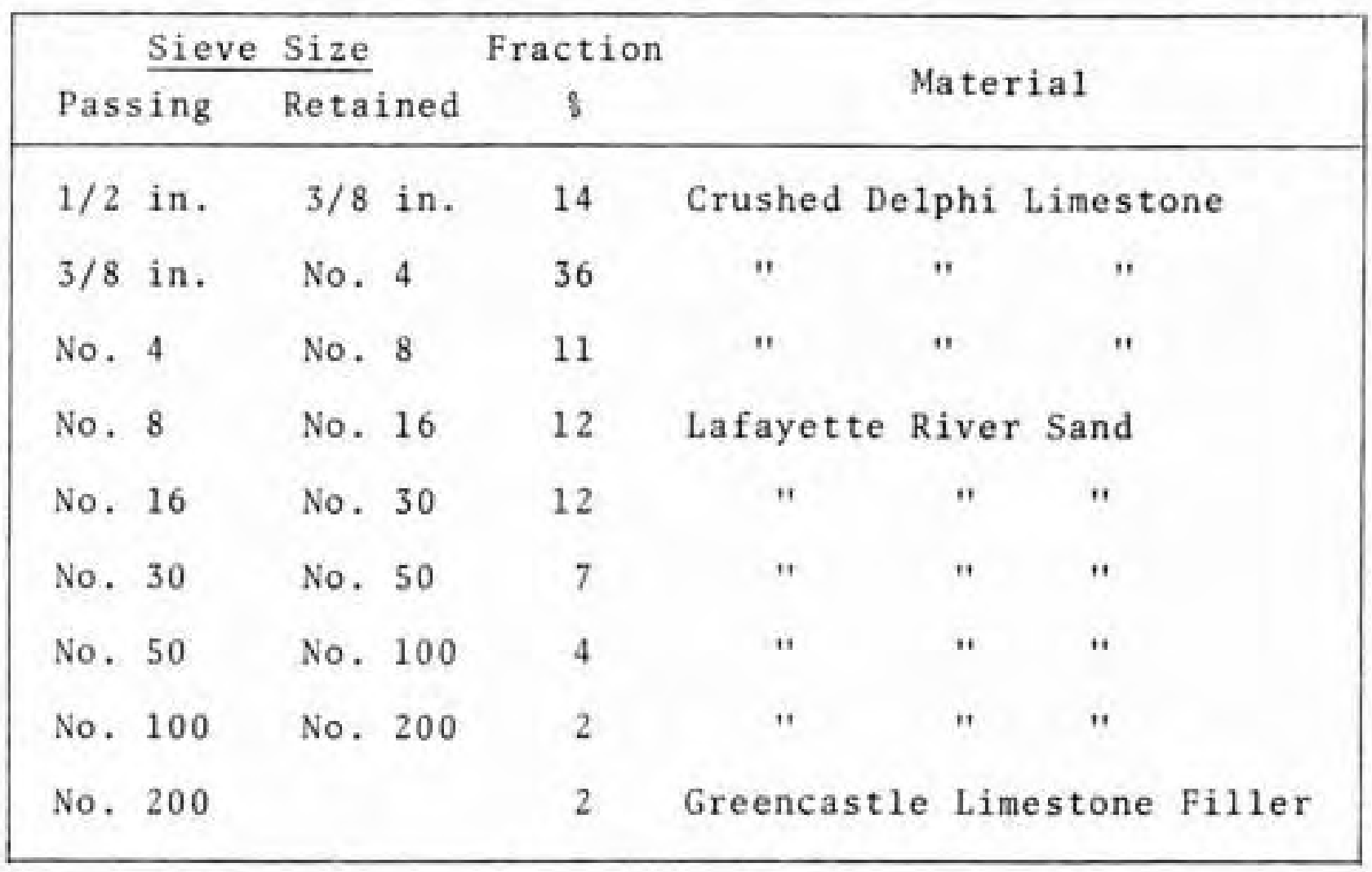




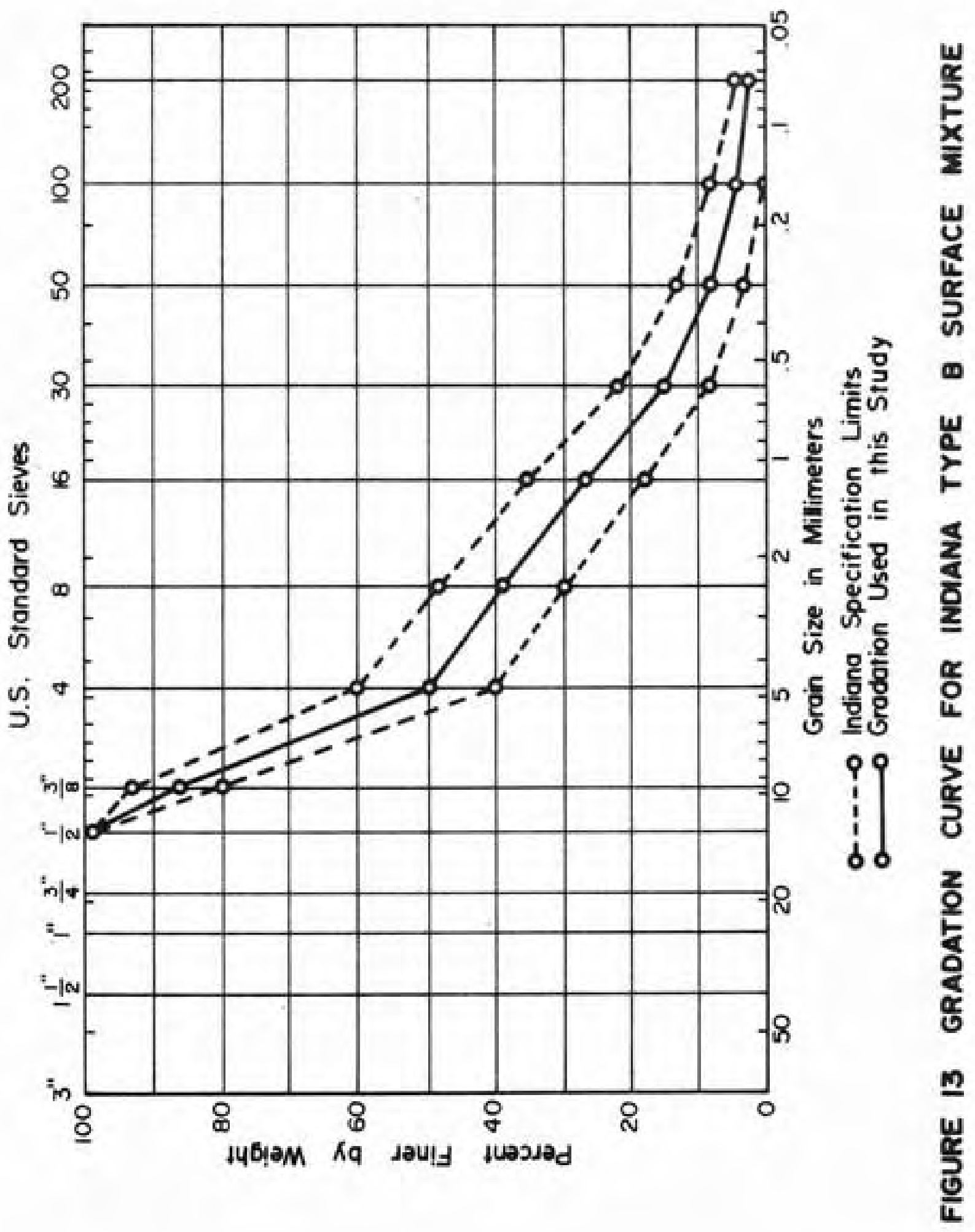




\section{TABLE 3}

RESULTS OF TESTS ON ASPHALT CEMENT

Penetration, $100 \mathrm{grams}, 5 \mathrm{sec}, 77^{\circ} \mathrm{F}^{1} \ldots \ldots 2$
Penetration, $200 \mathrm{grams}, 60 \mathrm{sec}, 32^{\circ} \mathrm{F}^{1 \ldots \ldots} \ldots 16$ Loss on Heating, 50 grams, $5 \mathrm{hr}, 325^{\circ} \mathrm{F}^{2} \& \cdots 0.02$ Penetration of Residue, ${ }^{1,2} \&$ of Original ... 83 Softening Point, Ring and Ball, ${ }^{3}{ }^{\circ} \mathrm{F} \ldots \ldots$ Specific Gravity at $77^{\circ} \mathrm{F} \ldots \ldots 1.011$ Flash Point, Cleveland Open Cup, ${ }^{5}{ }^{\circ} \mathrm{F} \ldots \ldots . . .581$ Ductility at $77^{\circ} \mathrm{F}, 5 \mathrm{~cm} / \mathrm{min} .,^{6} \mathrm{~cm} \ldots 150^{+}$ Kinematic Viscosity at $275^{\circ} \mathrm{F},{ }^{7} \mathrm{cSt} \ldots \ldots+\ldots$ Kinematic Viscosity at $325^{\circ} \mathrm{F},{ }^{\prime} \mathrm{cSt} \ldots 137$

1 ASTM D 5

2 ASTM D 6

3 ASTM D 36

- ASTM D 70

5 ASTM D 92

6 ASTM D 113

7 ASTM D 2170 


\begin{tabular}{|lccc|}
\hline Specimen & $\begin{array}{c}\text { Unit Weight } \\
\left(1 \mathrm{bs} . / \mathrm{ft}^{3}\right)\end{array}$ & $\begin{array}{c}\text { Hveem } \\
\text { Stability }\end{array}$ & $\begin{array}{c}\text { Air Voids } \\
(\mathrm{s})\end{array}$ \\
\hline A60-1 & 150.72 & 36.8 & 3.66 \\
A60 - & 151.01 & 57.8 & 3.85 \\
A60-3 & 149.82 & 49.7 & 5.07 \\
Average & 150.52 & 48.1 & 4.19 \\
\hline
\end{tabular}

Prior to preparing the bituminous mixture to be used as surface course for the pavement models, compaction and leveling experimentation was conducted with the air hammer and vibrator. Although the devices proved to be satisfactory in placing the base course, it was thought essential to correlate, by trial, the time of compaction and leveling with the compactive effort required to obtain the design density at the selected asphalt content.

The mixture for the surface course was prepared by weighing $5000-\mathrm{gram}$ batches of total aggregate, heating the aggregate to $325^{\circ} \mathrm{F}$ and then mixing it with the asphalt, heated to the same temperature, in a mechanical mixer for two minutes. After mixing was completed, each batch was put in a flat pan and placed in a forced-air draft oven to cure for 15 hours at $140^{\circ} \mathrm{F}$.

To minimize the temperature loss from the mixture due to air drifts from the air hamer during compaction, the constant temperature room was set to the maximum operating temperature of $113^{\circ} \mathrm{F}$. Compaction of the bituminous mixture 
was started after the mixture was reheated to $325^{\circ} \mathrm{F}$. The hot mixture was spread uniformly over the base course in one layer such that the compacted thickness would be one inch. The sides of the box served as the form for laying and compacting the mixture. The bituminous mixture was compacted and leveled by the heated air hammer and vibrator for the predetermined time. The density obtained for the one-inch asphaltic concrete surfacing was $149.8 \mathrm{pcf}$. The in-place void content corresponding to this density was calculated to be 4.6 percent.

Upon completion of the tests with the model pavement having a one-inch surfacing, more batches of bituminous mixture to increase the surfacing thickness to two inches were prepared in the above manner. A wooden form, with $32 \frac{1}{2}$ by $32 \frac{1}{2}$ by $3 \frac{1}{2}$ inches internal dimensions connected to the top of the box was used during spreading and compaction of the mixture over the one-inch asphalt surface. Figure 14 shows the bituminous mixture under compaction. Leveling of the surface by the vibrator is shown in Figure 15. The same compactive effort was applied to give the same density as for the one-inch surface.

\section{Instrumentation}

Instrumentation was carried out with consideration for recording the time-dependent input and output parameters. A crucial part of the instrumentation technique lies in devising a system which is capable of applying an impulse 


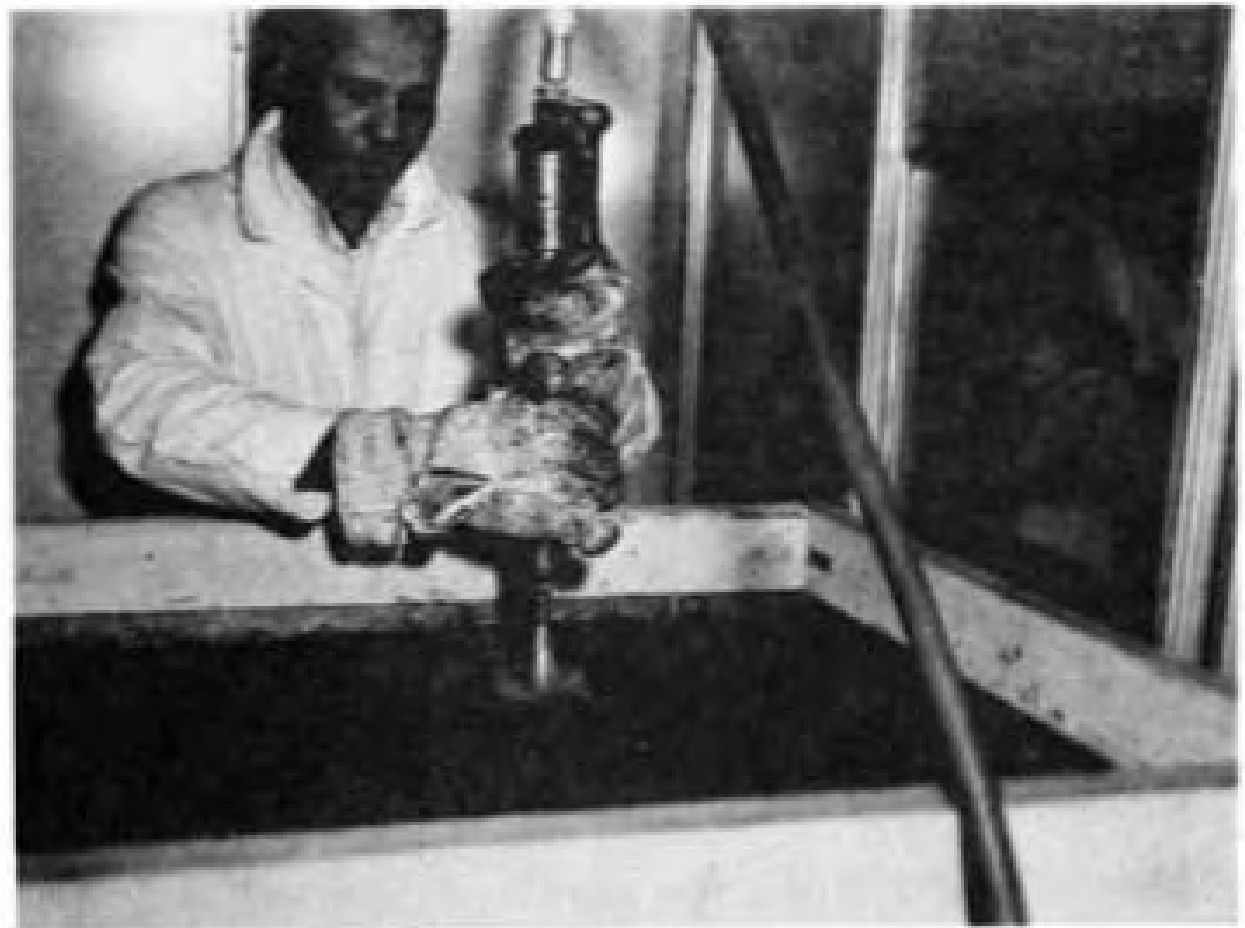

FIGURE 14 BITUMINOUS MIXTURE UNDER COMPACTION 


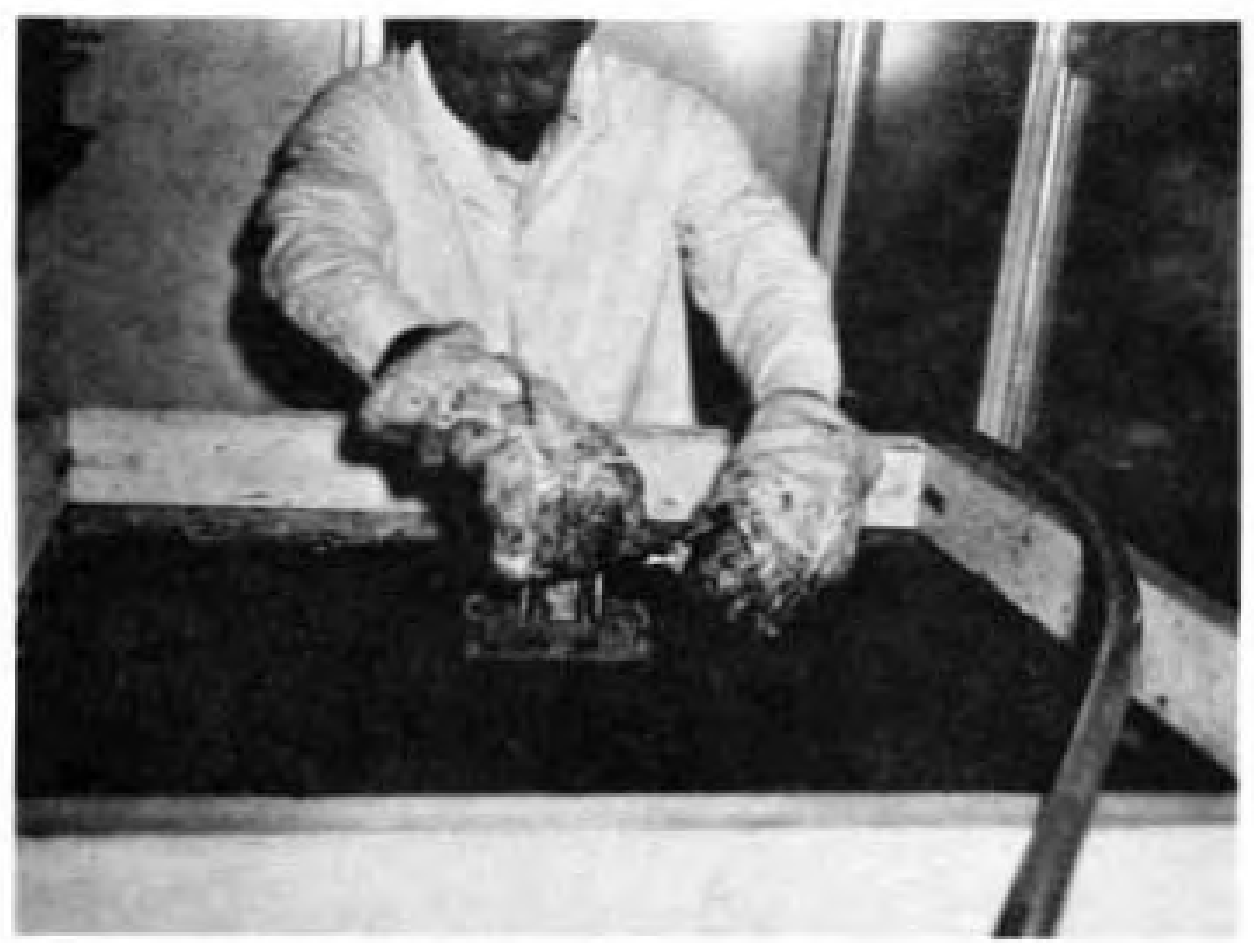

FIGURE IS LEVELING OF THE SURFACE COURSE 
force of a desired magnitude and duration, and of detecting the surface motion at any required location on the pavement surface.

The equipment consisted of a loading frame designed and fabricated of steel members coupled with an MTS electrohydraulic actuator. Details of the loading frame and the rigid support for the model pavements are shown in Figure 16. A mechanical holder was made of methyl methacrylate and connected to the top plate (item 9 ) of the loading frame. The purpose was to hold the servoram while the MTS console was being programmed in tension prior to applying a single compressive square wave. The generation of an impulse by this technique is schematically illustrated in Figure 17. Loads were applied by the MTS machine and measured with a 1000-1b. capacity Strainsert load ce11, type FL1U, mounted between the hydraulic actuator and the loading plate. The output of the load cell was recorded with a Brush Mark 280 two-channel recorder.

Five Sanborn Linearsyn linear variable differential transformers (LVDT's) were used to sense the deflections. For the center loading, one LVDT, designated as no. 3, was located 3.25 inches from the center of the loading plate. The other four were spaced 2.5 inches apart along the same radial line as LVDT no. 3. Figure 18 shows the locations of the LVDT's during corner loading. 


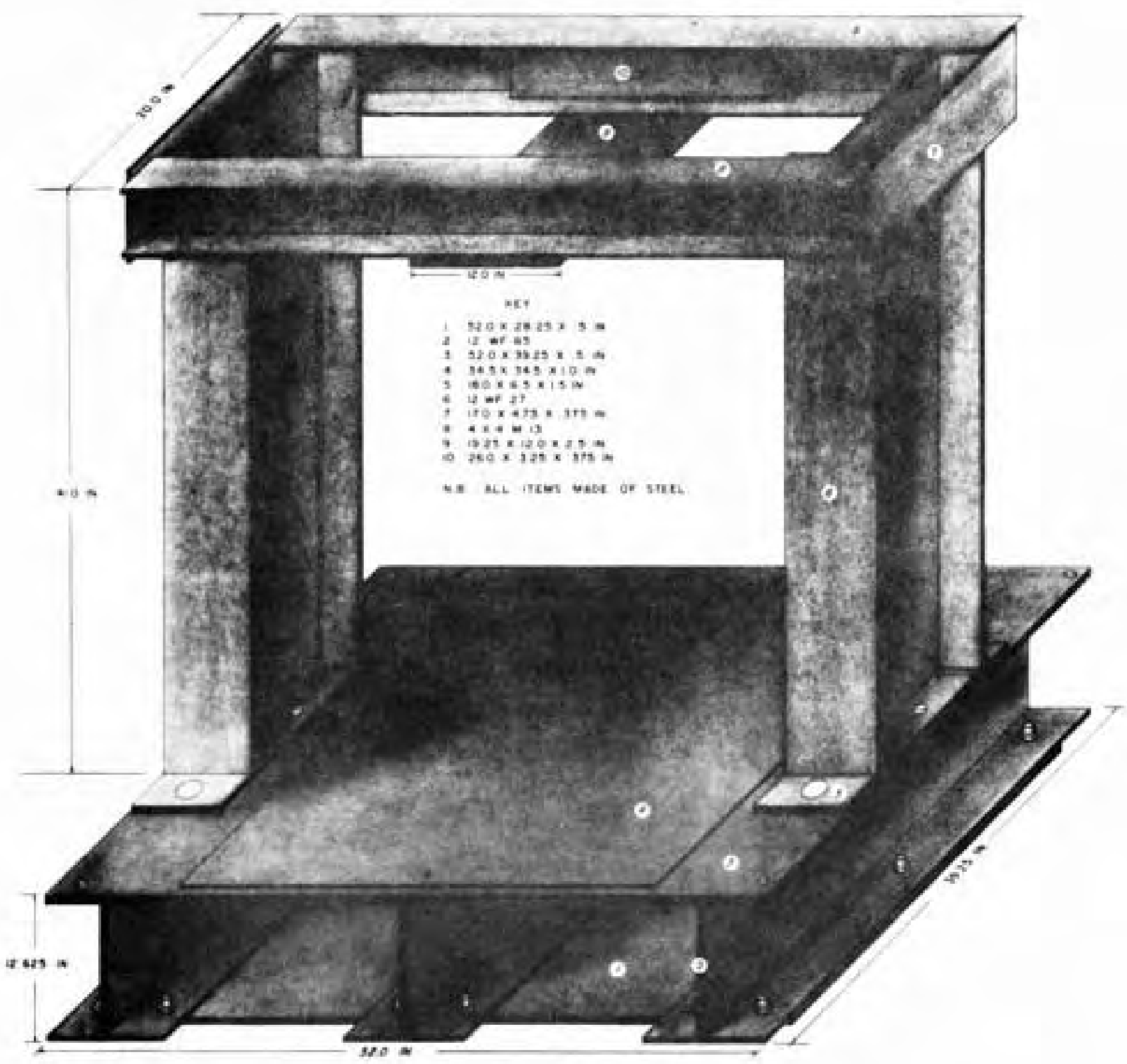

FIGURE 16 LOADING FRAME AND MODEL PAVEMENT SUPPORT 


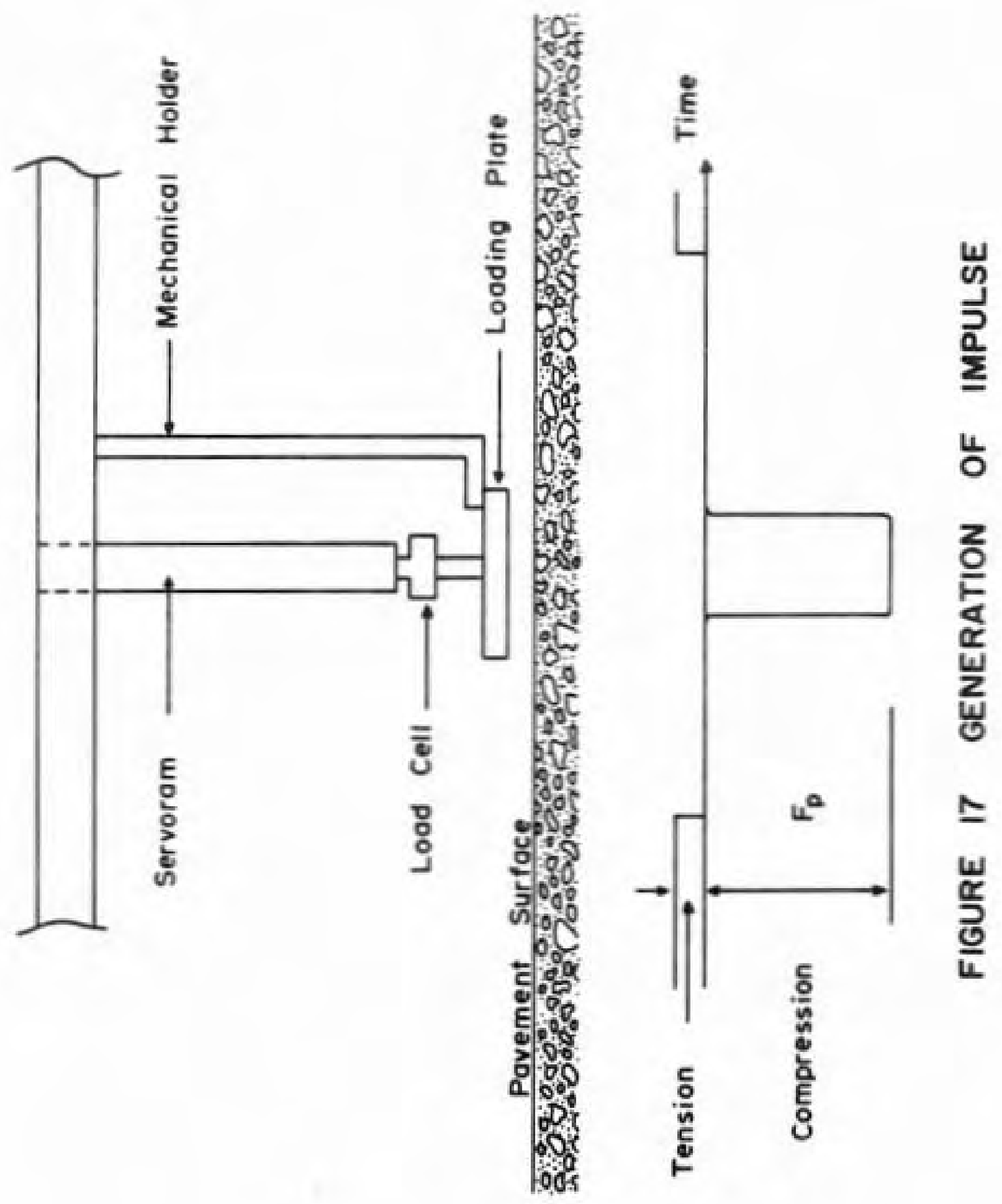




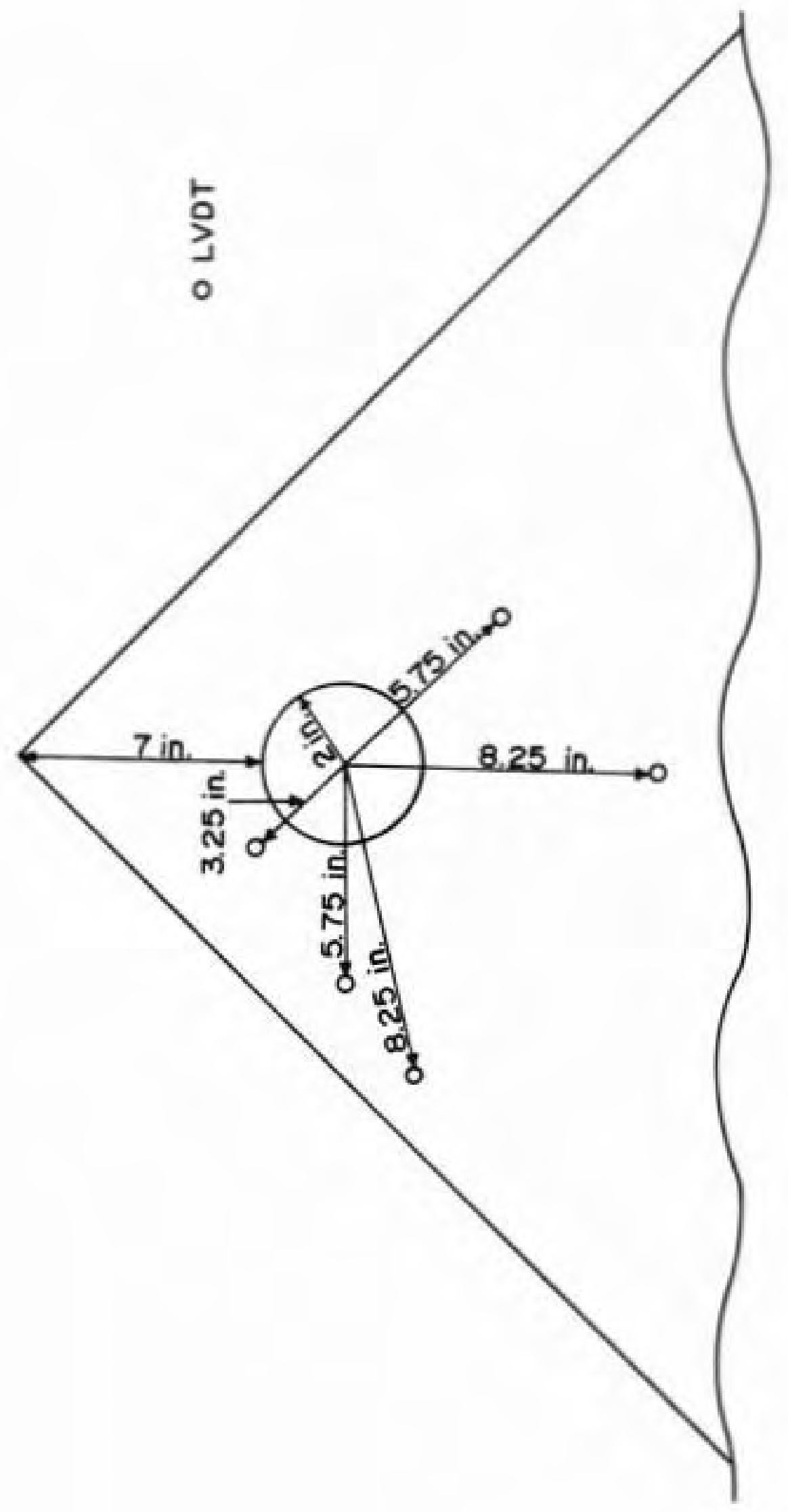

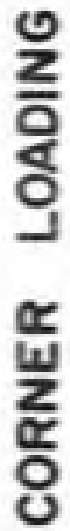

弟

安

$\frac{4}{5}$

แ

음

$\underline{\Phi}$

嵌 
Changes in output voltage from the LVDT's were amplified and recorded by an 8-channel Sanborn recorder. Calibration of the LVDT's was effected by displacing the core of the LVDT with a micrometer and relating this displacement to the magnitude of the pen deflection of the recorder. A typical calibration sheet for the LVDT's is shown in Table 4. One dial gage located at the same radial distance as LVDT no. 2 from the center of the load, but as close as possible to the LVDT, served as a check during static and cyclic testing.

The LVDT's were fixed to the pavement surface by screwing one end of a brass extension rod into the LVDT core and the other end into a $\frac{?}{4}$-inch by $\frac{1}{2}$-inch by -inch thick brass plate. The plate was in turn glued to the appropriate location on the pavement surface using Eastman 910 Adhesive. The LVDT's were supported by aluminum channels and plexiglas beams connected to the top angles of the box. Figure 19 shows the general view of the test set-up inside the constant temperature room for the center loading. A close view of the LVDT's is shown in Figure 20.

\section{$\underline{\text { Test }}$ Procedures}

Three tests are described in this section: impulse, static and repeated tests. The coding shown in Figure 21 was used to make data identification orderly. 
TABLE 4

TYPICAL FORMAT FOR LVDT CALIBRATION

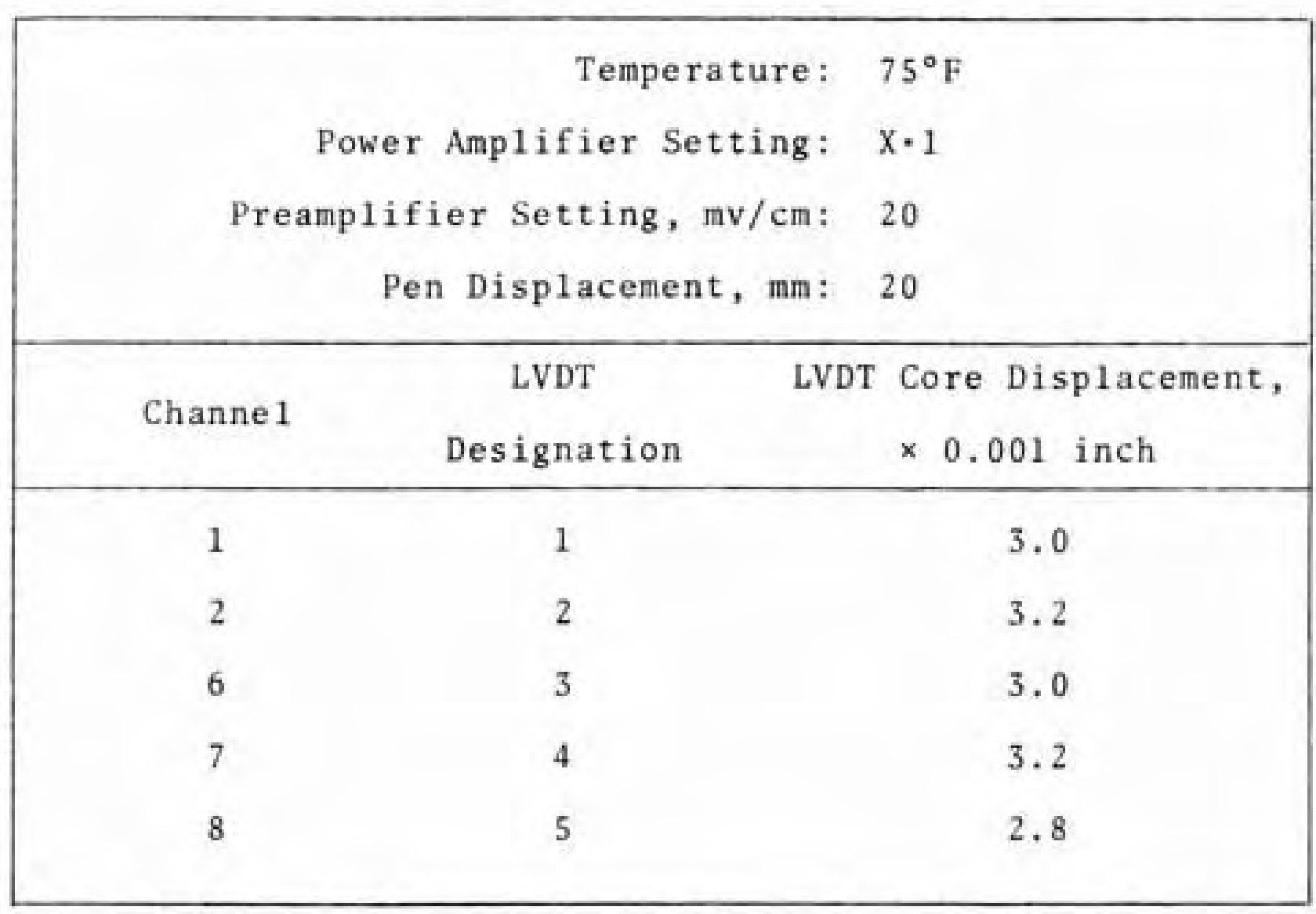




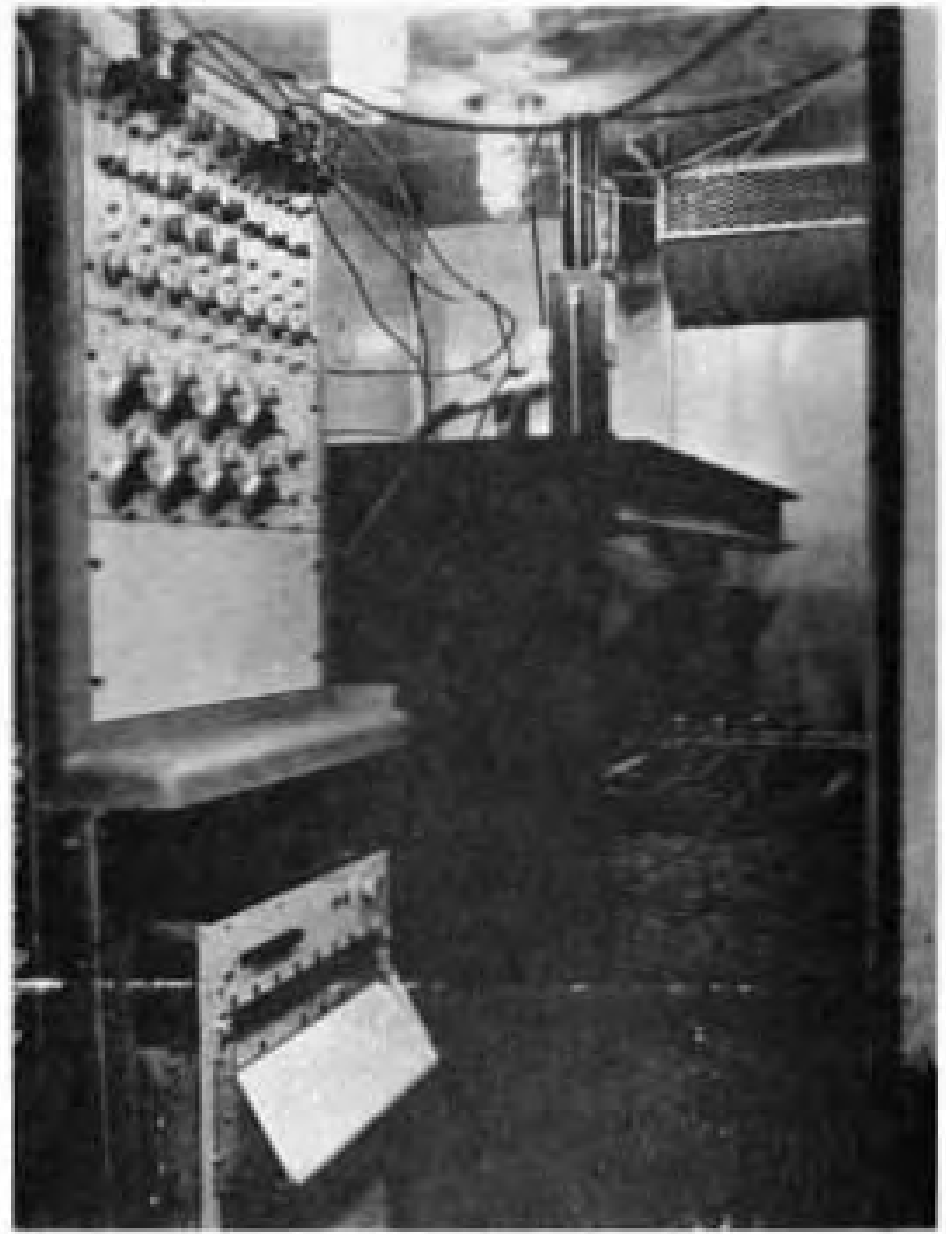

FIGURE I9 GENERAL VIEW OF TEST SETUP 


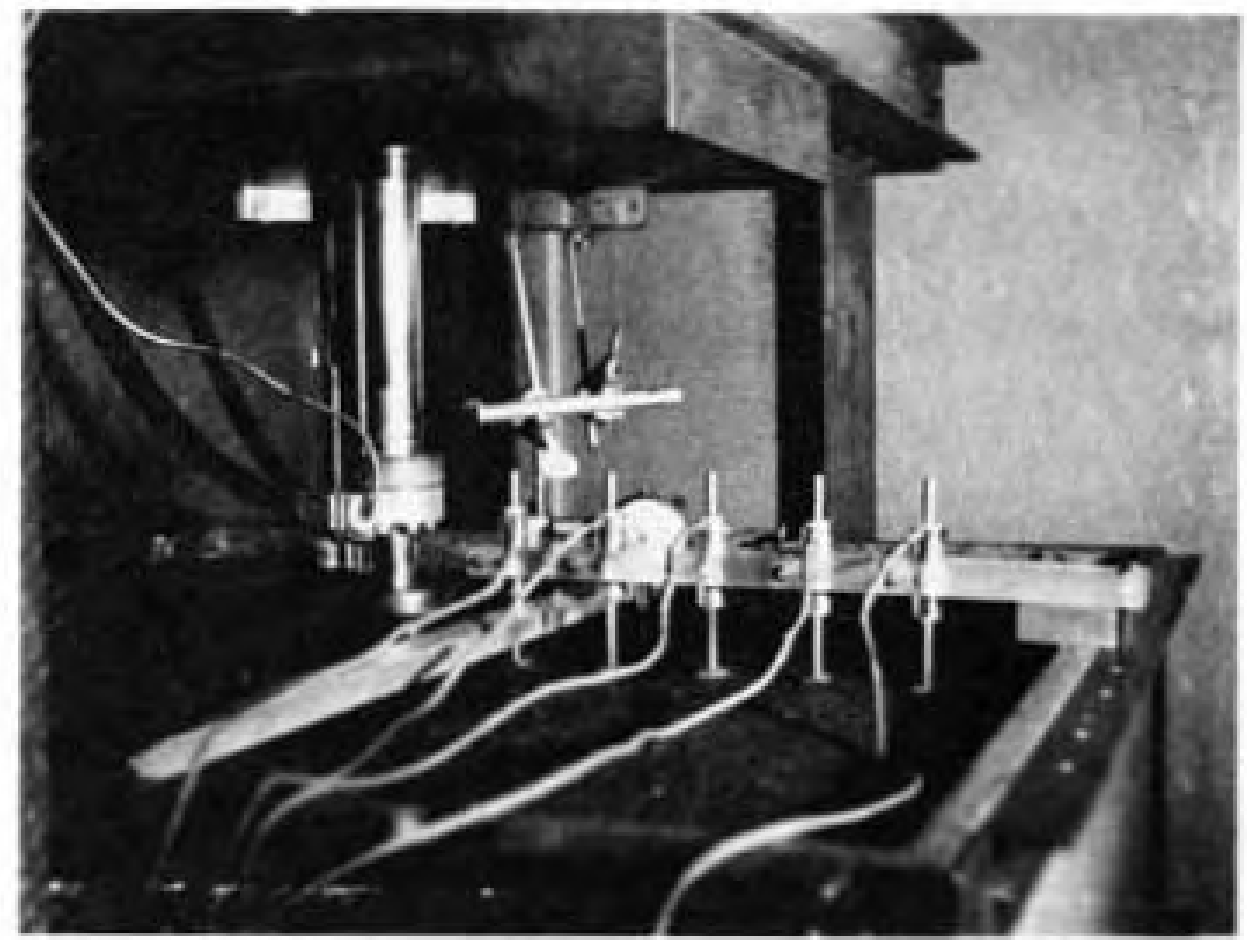

FIGURE 20 CLOSE VIEW OF TEST SETUP 


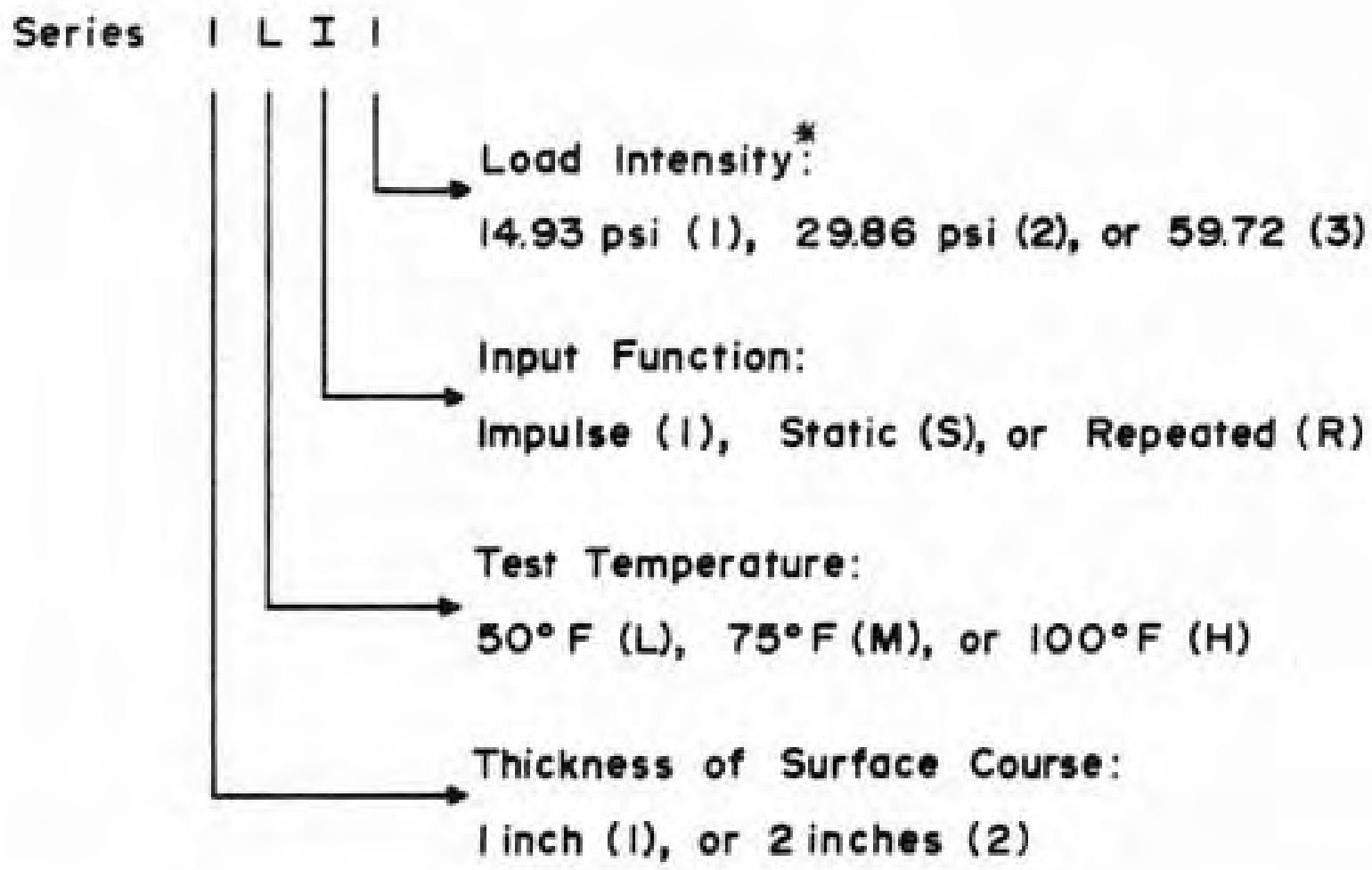

* Applied to a 4-inch diameter plate, these pressures omount to, respectively, $187.5,375.0$, and 750.0 Ibs. 
Impulse Load Tests

With the function generator in the square-wave mode and by suitable manipulation of the MTS console, impulse load magnitudes of $187.5, * 375.0$ and $7501 \mathrm{bs}$. were applied for a duration of about $0.16 \mathrm{sec}$. This time and a drop height of 0.5 inch were determined from preliminary tests during conditioning of the model pavements.

Typical traces of input load and output deflections are shown in Figure 22. A format for data reduction is illustrated in Table 5 .

\section{Static Load Tests}

For static load tests, the frequency of the MTS machine was set at one cycle per second, the function generator in the ramp mode and the control mode in the manual trigger. By these adjustments, a static compressive force of the programmed magnitude was applied. The load was held on until the deflections became almost constant with time. This was found to be in the order of a few minutes.

Figure 23 shows representative graphical data for this type of test.

\section{Repeated Load Tests}

In advance of starting a cyclic load test, the function generator of the MTS machine was programmed in the compressive haversine form and in the control mode. Once testing started,

* For Series 1HI1, the peak load was found to be $180.01 \mathrm{bs}$. 


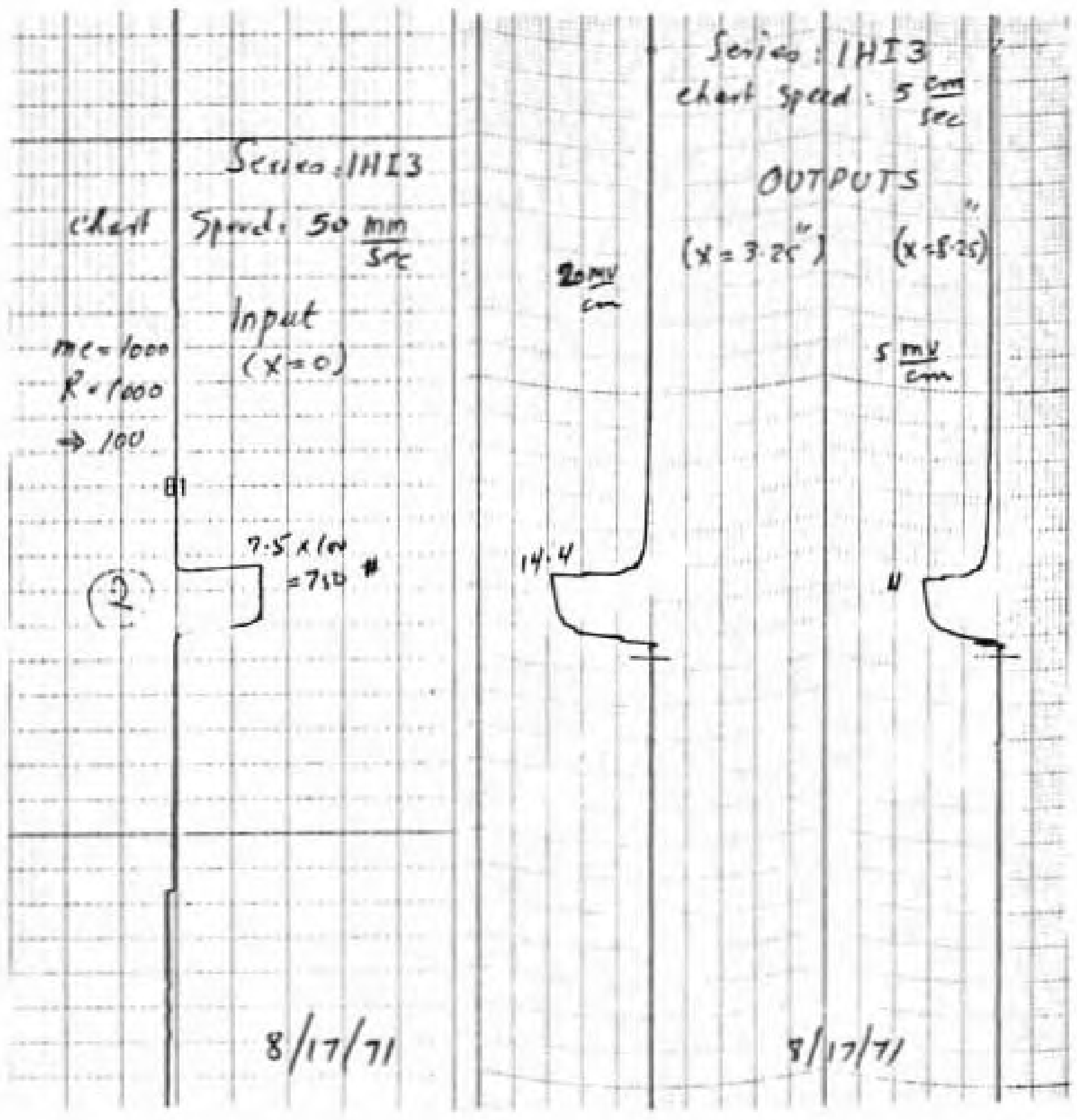

FIGURE 22 TYPICAL TRACES OF AN IMPULSE LOAD TEST 
TABLE 5

TYPICAL DATA REDUCTION FOR IMPULSE TEST

Series: $1 \mathrm{HI} 3$

\begin{tabular}{|c|c|c|c|c|c|c|c|c|}
\hline \multirow{3}{*}{$\begin{array}{c}\text { Time } \\
\text { (sec.) }\end{array}$} & \multicolumn{8}{|c|}{ Distance from Load Center, ${ }^{\star}$ inches } \\
\hline & \multicolumn{2}{|r|}{0} & \multicolumn{2}{|c|}{3.25} & \multicolumn{2}{|c|}{5.75} & \multicolumn{2}{|c|}{8.25} \\
\hline & $\begin{array}{l}\text { Pen } \\
\text { Dispt. } \\
\text { mm }\end{array}$ & $\begin{array}{l}\text { Load } \\
\text { 1bs } \\
\times 100^{\star *}\end{array}$ & $\begin{array}{c}\text { Pen } \\
\text { Dispt. } \\
\text { min }\end{array}$ & $\begin{array}{l}\text { Def } 1 \mathrm{ec} . \\
\text { in. } \times 10^{-4} \\
\times 1.50^{* *}\end{array}$ & $\begin{array}{c}\text { Pen } \\
\text { Dispt. } \\
\text { min }\end{array}$ & $\begin{array}{l}\text { Def } 1 \text { ec. } \\
\text { in. } \times 10^{-4} \\
\times 0.80^{* *}\end{array}$ & $\begin{array}{c}\text { Pen } \\
\text { Dispt. } \\
\text { min }\end{array}$ & $\begin{array}{l}\text { Deflec. } \\
\text { in } \times 10^{-4} \\
\times 0.40^{* *}\end{array}$ \\
\hline 0. & 0 & 0 & 0 & 0 & & 0 & 0 & 0 \\
\hline 0.02 & 0 & 0 & 0 & 0 & 0 & 0 & 0 & 0 \\
\hline 0.04 & 1.0 & 100.0 & 0.6 & 0.90 & 1.0 & 0.80 & 1.0 & 0.40 \\
\hline 0.06 & 6.0 & 600.0 & 10.0 & 15.00 & 8.0 & 6.40 & 5.6 & 2.24 \\
\hline 0.08 & 7.5 & 750.0 & 11.4 & 17.10 & 12.0 & 9.60 & 8.6 & 3.44 \\
\hline 0.10 & 7.5 & 750.0 & 13.0 & 19.50 & 13.0 & 10.40 & 9.7 & 3.88 \\
\hline 0.12 & 7.5 & 750.0 & 13.6 & 20.40 & 13.4 & 10.72 & 10.2 & 4.08 \\
\hline 0.14 & 7.5 & 750.0 & 14.0 & 21.00 & 13.8 & 11.04 & 10.3 & 4.12 \\
\hline 0.16 & 7.5 & 750.0 & 14.1 & 21.15 & 14.0 & 11.20 & 10.4 & 4.16 \\
\hline 0.18 & 7.5 & 750.0 & 14.2 & 21.30 & 14.4 & 11.52 & 10.6 & 4.24 \\
\hline 0.20 & 7.5 & 750.0 & 14.4 & 21.60 & 14.6 & 11.68 & 10.7 & 4.28 \\
\hline 0.22 & 7.5 & 750.0 & 14.5 & 21.75 & 14.8 & 11.84 & 10.8 & 4.32 \\
\hline 0.24 & 0 & 0 & 8.0 & 12.00 & 6.0 & 4.80 & 8.0 & 3.20 \\
\hline 0.26 & 0 & 0 & 3.0 & 4.50 & 3.5 & 2.80 & 4.0 & 1.60 \\
\hline 0.28 & 0 & 0 & 1.6 & 2.40 & 2.6 & 2.08 & 2.8 & 1.12 \\
\hline 0.30 & 0 & 0 & 1.4 & 2.10 & 2.2 & 1.76 & 2.0 & 0.80 \\
\hline 0.32 & 0 & 0 & 1.2 & 1.80 & 2.0 & 1.60 & 1.9 & 0.76 \\
\hline 0.34 & 0 & 0 & 1.1 & 1.65 & 1.9 & 1.52 & 1.8 & 0.72 \\
\hline 0.36 & 0 & 0 & 1.0 & 1.50 & 1.8 & 1.44 & 1.6 & 0.64 \\
\hline 0.38 & 0 & 0 & 0.8 & 1.20 & 1.7 & 1.36 & 1.5 & 0.60 \\
\hline 0.40 & 0 & 0 & 0.7 & 1.05 & 1.5 & 1.20 & 1.4 & 0.56 \\
\hline 0.42 & 0 & 0 & 0.6 & 0.90 & 1.4 & 1.12 & 1.3 & 0.52 \\
\hline 0.44 & 0 & 0 & 0.6 & 0.90 & 1.3 & 1.04 & 1.2 & 0.48 \\
\hline 0.46 & 0 & 0 & 0.6 & 0.90 & 1.2 & 0.96 & 1.1 & 0.44 \\
\hline 0.48 & 0 & 0 & 0.6 & 0.90 & 1.1 & 0.88 & 1.1 & 0.44 \\
\hline 0.50 & 0 & 0 & 0.6 & 0.90 & 1.1 & 0.88 & 1.1 & 0.44 \\
\hline
\end{tabular}

* The deflection functions recorded at distances 10.75 and 13.25 inches were too sma11 to justify this type of data reduction.

** Calibration Factors, 1bs./mm or in. $\times 10^{-4} / \mathrm{mm}$ 


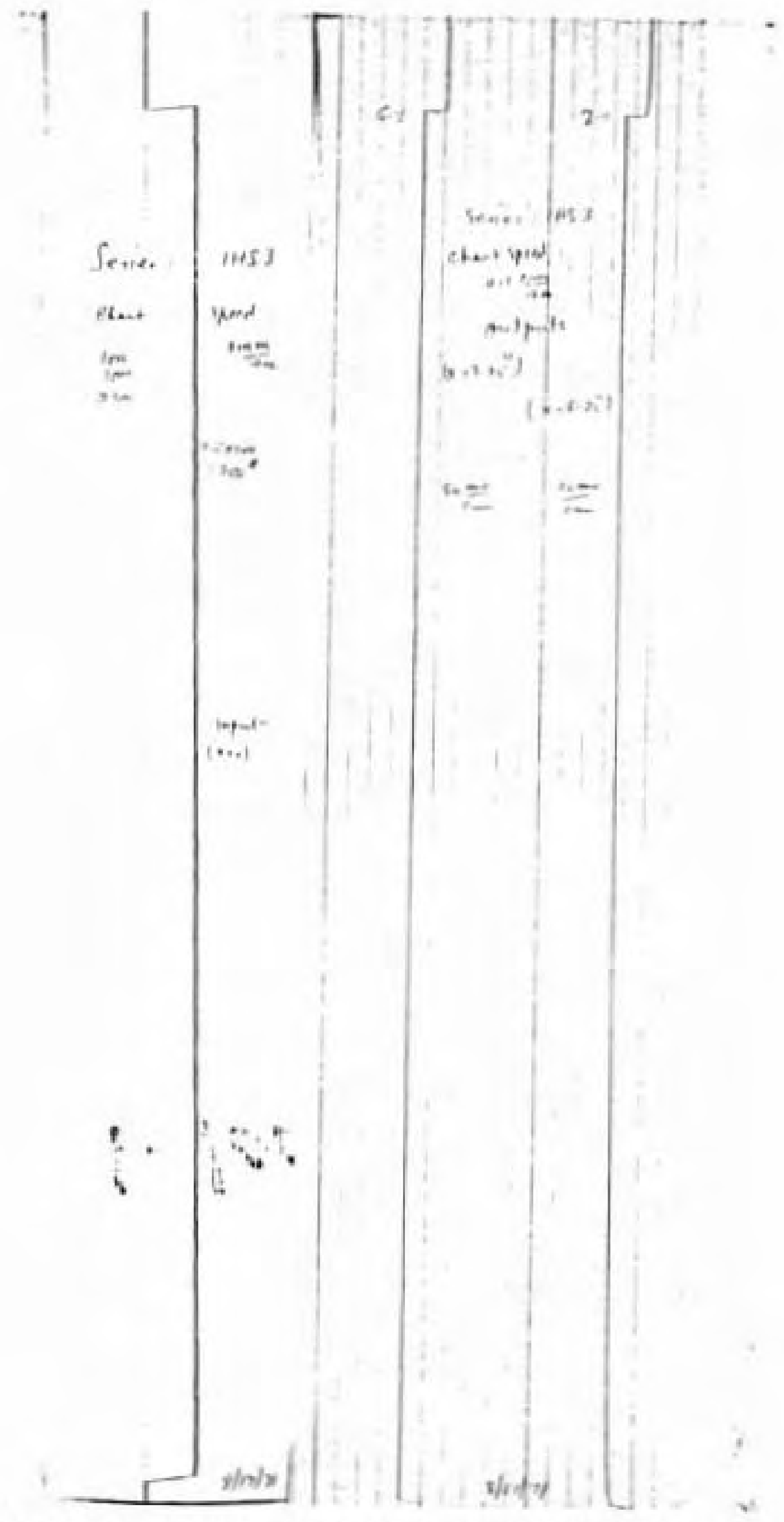

FIOURE 23 TYPICAL TRACES OF A STATIC LOAD TEST 
the hydraulic actuator moved up and down from zero load to maximum and back to zero. This sequence was repeated automatically for the programmed number of 250 cycles at a rate of 15 cycles per minute.

Typical traces of repeated load input and deflection outputs are illustrated in Figure 24. Formats for data reduction are shown in Tables 6 and 7 , respectively, for static and repeated load tests. 


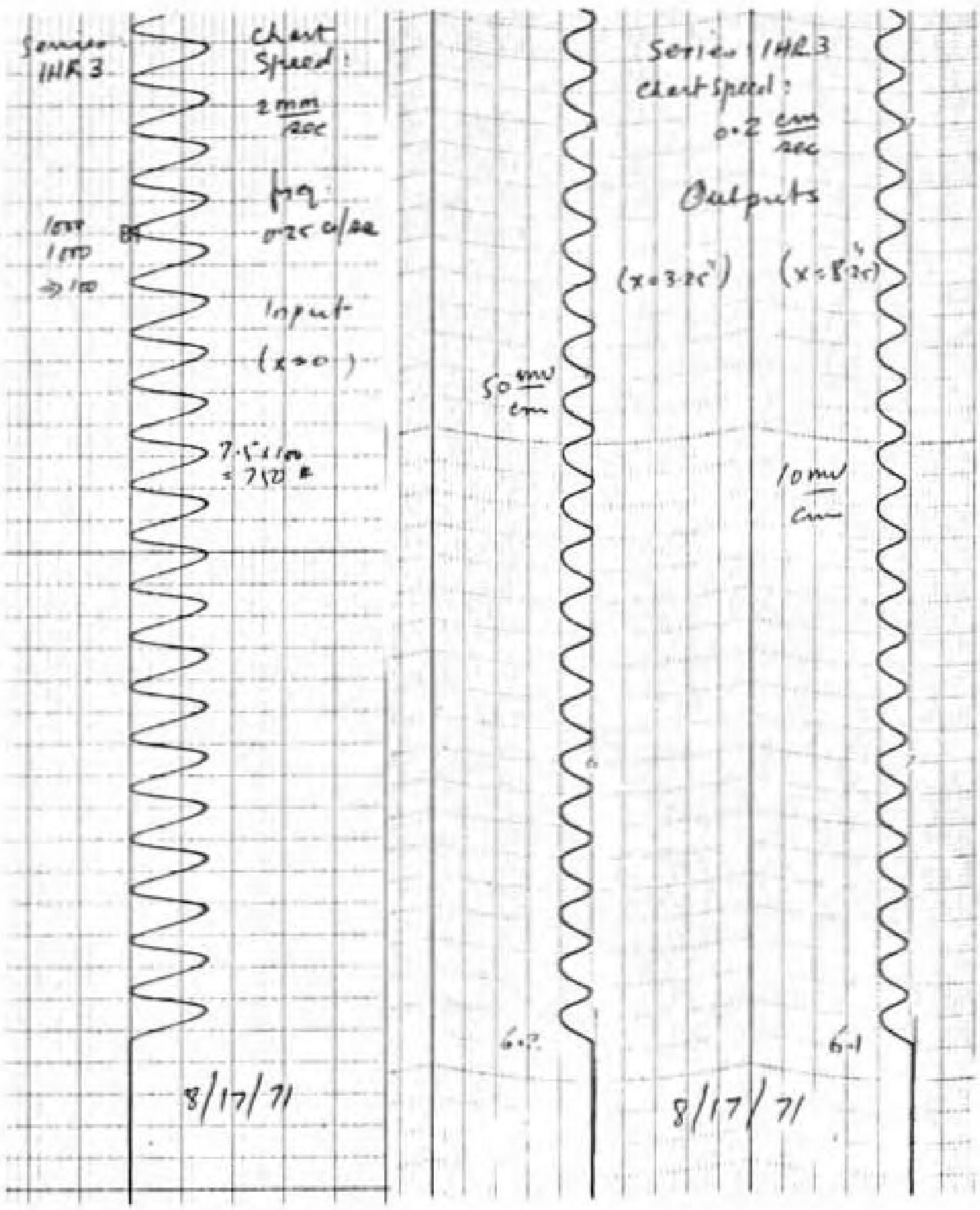

\section{FIGURE 24 TYPICAL TRACES OF A REPEATED} LOAD TEST 
TABLE 6

TYPICAL DATA REDUCTION FOR STATIC TEST

Series: 1 HS 3

\begin{tabular}{|ccccc|}
\hline $\mathrm{x}$ & $\begin{array}{c}\text { Preamp. } \\
\text { Setting } \\
\mathrm{mv} / \mathrm{cm}\end{array}$ & $\begin{array}{c}\text { Calib. } \\
\text { Factor } \\
\text { in. } \times 10^{-4} / \mathrm{mm}\end{array}$ & $\begin{array}{c}\text { Pen } \\
\text { Dispt. } \\
\mathrm{mm}\end{array}$ & $\begin{array}{c}\text { Total } \\
\text { Deflec. } \\
\text { in. } \times 10^{-4}\end{array}$ \\
\hline 3.25 & 50 & 4.000 & 6.4 & 25.60 \\
5.75 & 20 & 1.600 & 9.0 & 14.40 \\
8.25 & 10 & 0.800 & 7.0 & 5.60 \\
10.75 & 5 & 0.375 & 2.0 & 0.75 \\
13.25 & 2 & 0.140 & 0.0 & 0.0 \\
\hline
\end{tabular}

TABLE 7

TYPICAL DATA REDUCTION FOR REPEATED TEST

Series: 1 HR 3

\begin{tabular}{|ccccc|}
\hline$x$ & $\begin{array}{c}\text { Preamp. } \\
\text { Setting } \\
\text { mv/cm }\end{array}$ & $\begin{array}{c}\text { Calib. } \\
\text { Factor } \\
\text { in. } \times 10^{-4} / \mathrm{mm}\end{array}$ & $\begin{array}{c}\text { Pen } \\
\text { Dispt. } \\
\mathrm{mm}\end{array}$ & $\begin{array}{c}\text { Total } \\
\text { Deflec. } \\
\text { in. } \times 10^{-4}\end{array}$ \\
\hline 3.25 & 50 & 4.000 & 6.2 & 24.80 \\
5.75 & 20 & 1.600 & 8.2 & 13.12 \\
8.25 & 10 & 0.800 & 6.1 & 4.88 \\
10.75 & 5 & 0.375 & 1.9 & 0.71 \\
13.25 & 2 & 0.140 & 0.0 & 0.0 \\
\hline
\end{tabular}




\section{RESULTS AND DISCUSSION}

The theory and experimental techniques to evaluate the response behavior of a pavement system were advanced in previous sections. The test data and analysis of results are presented in this Section and Appendix A together with their implications and the indicated relationships. The scope of the investigation included two flexible model pavements, differing in the thickness of the surface course, tested at three stress levels and three temperatures. Impulse, static and repeated loads were applied at the center of the pavements. Corner loadings were also conducted to investigate the edge effects that might result as a consequence of the sides of the box. For all series, surface deflections were recorded as functions of time at five locations. The results are presented and discussed in the following sequence:

1. Impulse Load Test Results

a. Normal Distribution and the Deflection Basin

b. Response Function of Flexible Pavements

c. Form of the Response Function

d. Check for the Response Function

e. Load-Independency of the Response Function

f. Effect of Temperature on the Response Function 


\section{g. Effects of Surface Course Thickness and Spatial Location}

2. Static Load Results

3. Repeated Load Resu1ts

4. Corner Loading Test Results

\section{Impulse Load Test Resu1ts}

The peak load magnitudes employed in most of the impulse tests were $187.5,375.0$ and 750.0 1bs. These correspond, respectively, to applied pressures of $14.93,29.86$ and $59.72 \mathrm{psi}$. The time duration was 0.16 second. This was established by adjusting the drop height of the hydraulic actuator and the frequency of the MTS function generator. The capability of the testing equipment was a limiting factor in using time duration less than 0.16 second.

\section{Normal Distribution and the Deflection Basin}

The peak values from the deflection functions are presented in Table 8 and plotted in Figures 25 through 30. These data indicate that in all cases the deflections increase with increase in temperature. This was to be expected since asphaltic materials are thermoplastic and an increase in temperature will result in increase of their flow characteristics.

As the thickness of a pavement structure is increased, the resistance to imposed loads increases and the system tends to deform less. However, this behavior was not uniform 
TABLE 8

PEAK DEFLECTIONS FROM IMPULSE TESTS

\begin{tabular}{|c|c|c|c|c|c|}
\hline \multirow{3}{*}{ Series } & \multicolumn{5}{|c|}{$y(x)$, inch $\left(\times 10^{-4}\right)$} \\
\hline & \multicolumn{5}{|c|}{ Distance from Load Center, inches } \\
\hline & 3.25 & 5.25 & 8.25 & 10.75 & 13.25 \\
\hline $1 \mathrm{LI} 1$ & 1.50 & 0.64 & 0.16 & $\cdots$ & -. \\
\hline $1 \mathrm{LI} 2$ & 2.48 & 0.77 & 0.32 & - & .. \\
\hline $1 \mathrm{~L} 13$ & 7.65 & 3.04 & 0.67 & - & $\ldots$ \\
\hline $1 \mathrm{MI} 1$ & 3.23 & 1.52 & 0.38 & -. & $\cdots$ \\
\hline $1 \mathrm{MI} 2$ & 7.50 & 4.00 & 0.86 & - & $\cdots$ \\
\hline $1 \mathrm{MI} 3$ & 15.00 & 8.00 & 2.00 & $\cdots$ & $\cdots$ \\
\hline $1 \mathrm{HI} 1$ & 4.05 & 2.24 & 0.78 & 0.03 & -. \\
\hline $1 \mathrm{HI} 1^{*}$ & 4.28 & 2.24 & 0.86 & 0.08 & $\cdots$ \\
\hline $1 \mathrm{HI} 2$ & 11.70 & 6.16 & 2.11 & 0.15 & - \\
\hline $1 \mathrm{HI} 3$ & 19.20 & 10.40 & 3.44 & 0.36 & $\cdots$ \\
\hline $1 \mathrm{HI} 3 *$ & 21.75 & 11.84 & 4.32 & 0.57 & - \\
\hline 2LI1 & 0.83 & 0.48 & 0.16 & .. & $\cdots$ \\
\hline $2 \mathrm{LI} 1^{*}$ & 0.75 & 0.42 & 0.18 & $\cdots$ & $\cdots$ \\
\hline $2 \mathrm{LI} 2$ & 1.43 & 0.83 & 0.22 & - & $\cdots$ \\
\hline $2 \mathrm{LI} 2$ * & 1.43 & 0.86 & 0.29 & . & - \\
\hline $2 \mathrm{LI} 3$ & 4.88 & 3.36 & 1.36 & 0.69 & 0.20 \\
\hline 2MI 1 & 1.91 & 1.40 & 0.74 & 0.38 & 0.22 \\
\hline $2 \mathrm{MI} 2$ & 3.75 & 2.76 & 1.44 & 0.75 & 0.32 \\
\hline $2 \mathrm{MI} 2$ * & 3.64 & 2.52 & 1.09 & 0.68 & 0.25 \\
\hline $2 \mathrm{MI} 3$ & 8.10 & 5.04 & 2.48 & 1.28 & 0.49 \\
\hline $2 \mathrm{MI}_{3}$ * & 8.40 & 5.12 & 2.52 & 1.43 & 0.53 \\
\hline $2 \mathrm{HI} 1$ & 3.60 & 2.40 & 1.04 & 0.68 & 0.22 \\
\hline $2 \mathrm{HII}^{*}$ * & 3.30 & 2.40 & 1.12 & 0.68 & 0.25 \\
\hline $2 \mathrm{HI} 2$ & 7.20 & 5.08 & 2.64 & 1. 43 & 0.78 \\
\hline $2 \mathrm{HI} 2 \star \star$ & 6.90 & 4.64 & 2.16 & 1.20 & 0.48 \\
\hline $2 \mathrm{HI} 2 * *$ & 6.90 & 4.80 & 2.24 & 1. 28 & 0.48 \\
\hline $2 \mathrm{HI} 3$ & 12.00 & 9.92 & 4.48 & 2.70 & 1.05 \\
\hline
\end{tabular}

* Represent duplicate series of tests.

** Represent triplicate series of tests. 


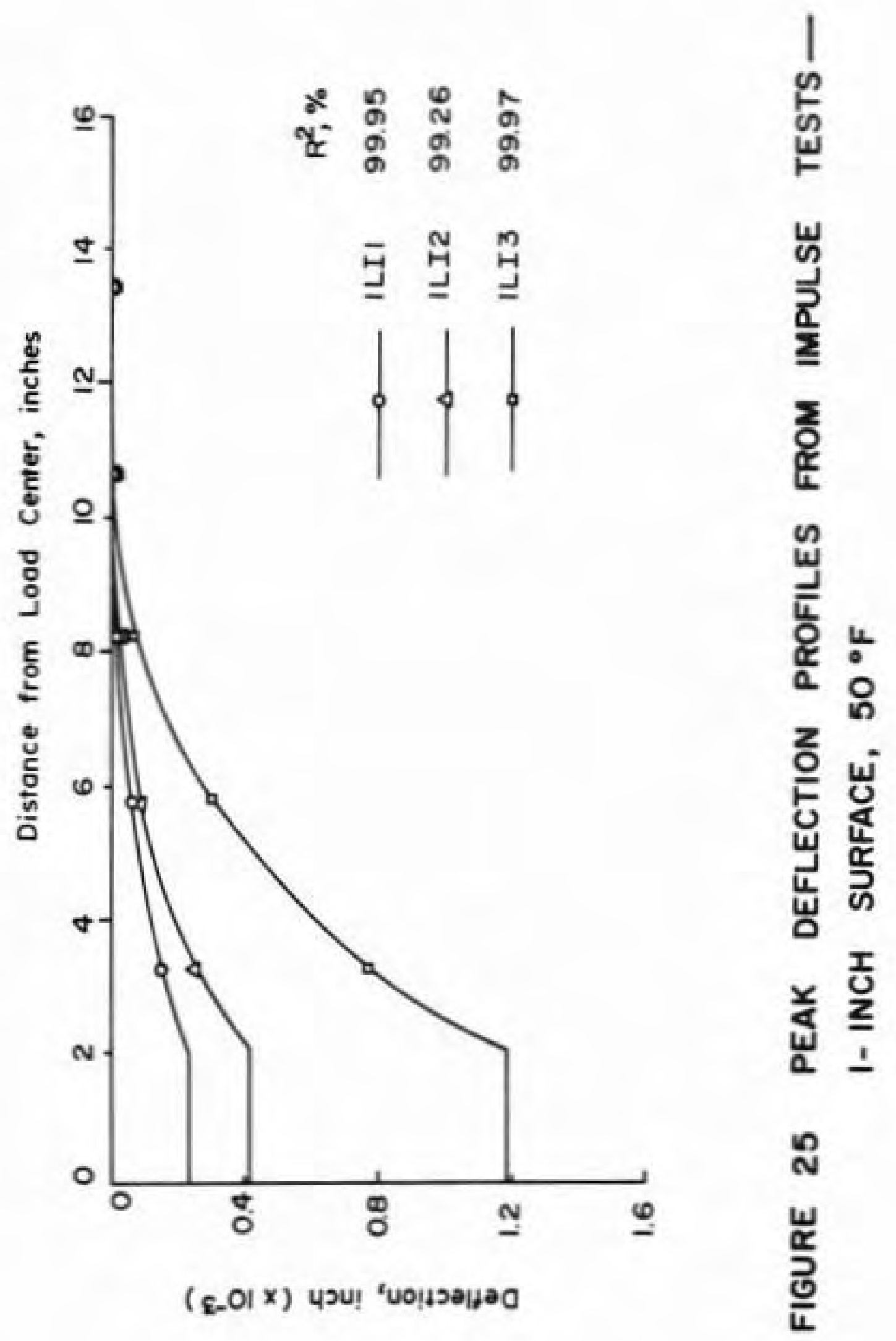




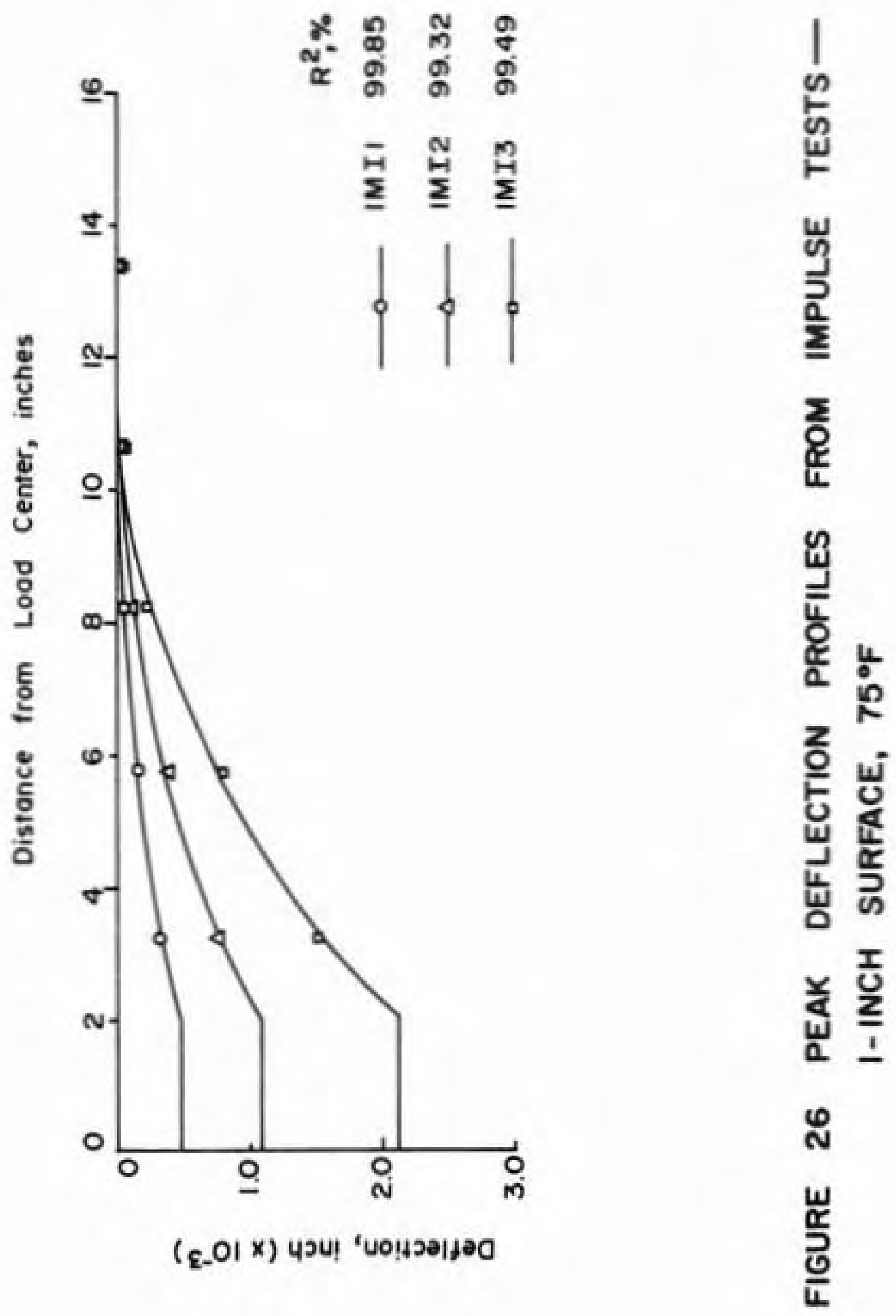




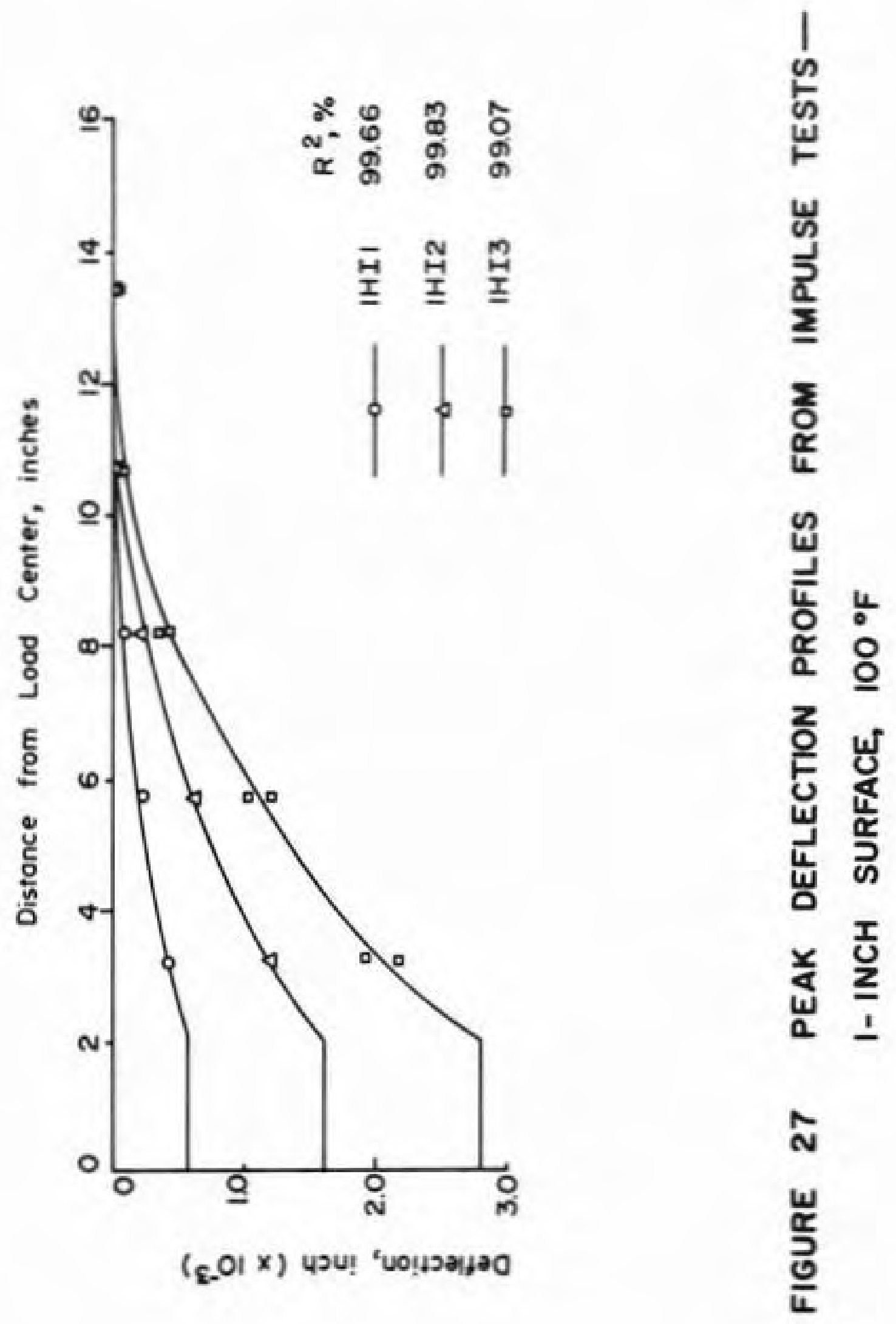




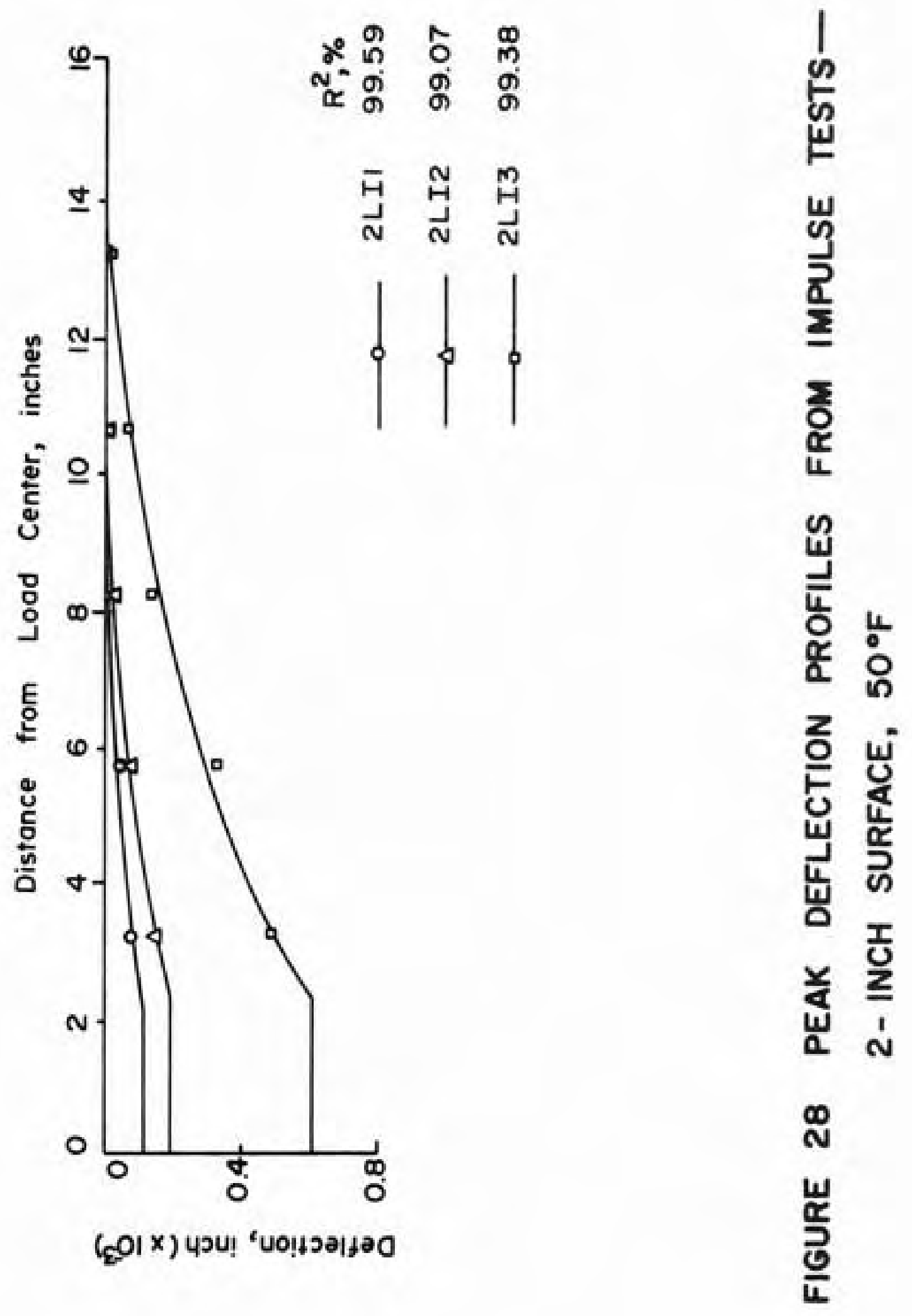




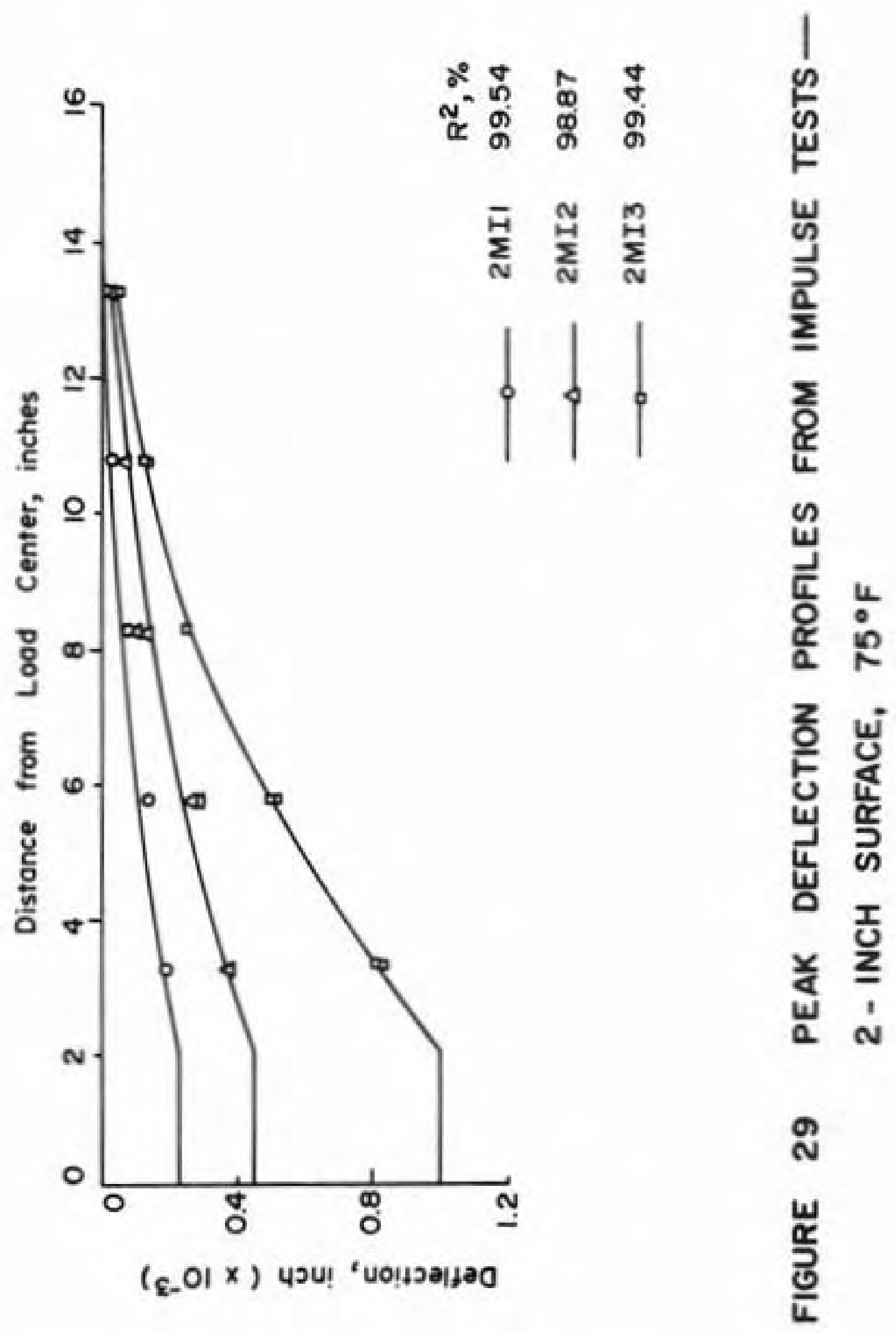




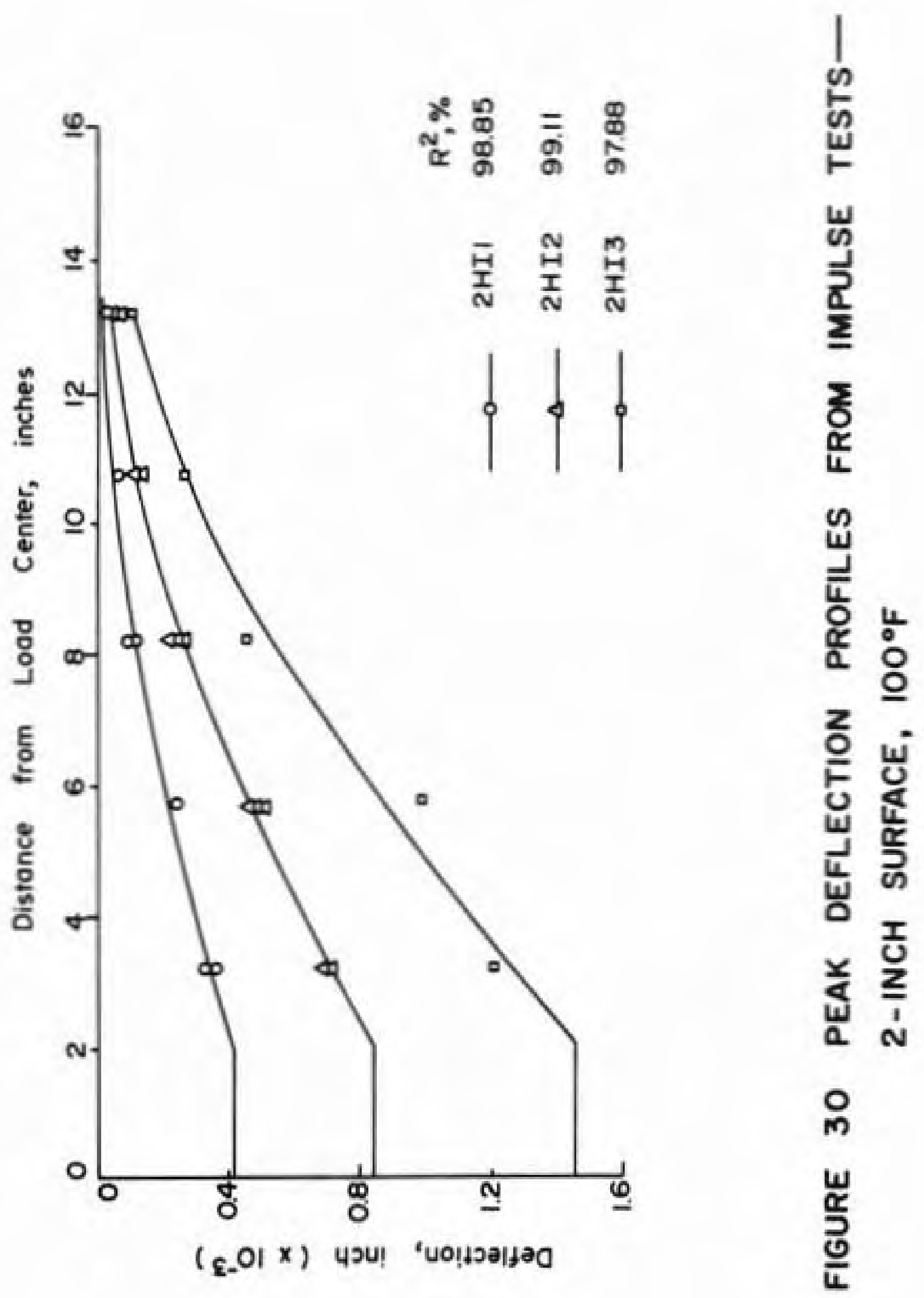


regarding the spatial locations $\mathrm{x}$ where measurements were made. At the two locations closest to the loaded position, decreased deflections were observed with increase in thickness, while at the other three locations, namely 8.25 inches and beyond, deflections increased with increasing thickness. See the typical conparisons made in Figure 31. This phenomenon was attributed to the slab action of the pavement system. When a system with a thicker surface is subjected to load, it will demonstrate less flexibility than would be the case for a thinner pavement. Consequently, the rate of decrease in deflection with increasing $x$ is less than that for a thinner surface.

The function selected to fit the peak deflection data of Table 8 was of the form

$$
y(x)=y_{0} e^{-D x^{2}}
$$

where $y(x)=$ the deflection at a distance $x$ from the load center, $y_{0}=$ the naximun deflection of the deflected basin, and

$D=a$ constant, reflecting the attenuation of the deflected basin with $x$.

The values of $y_{0}$ and $D$ determined by a non-1inear regression method are given in Table 9. The non-linear regression analysis gave squared correlation coefficients $\left(R^{2}\right)$, as reported in Table 9. These range from a little less than 


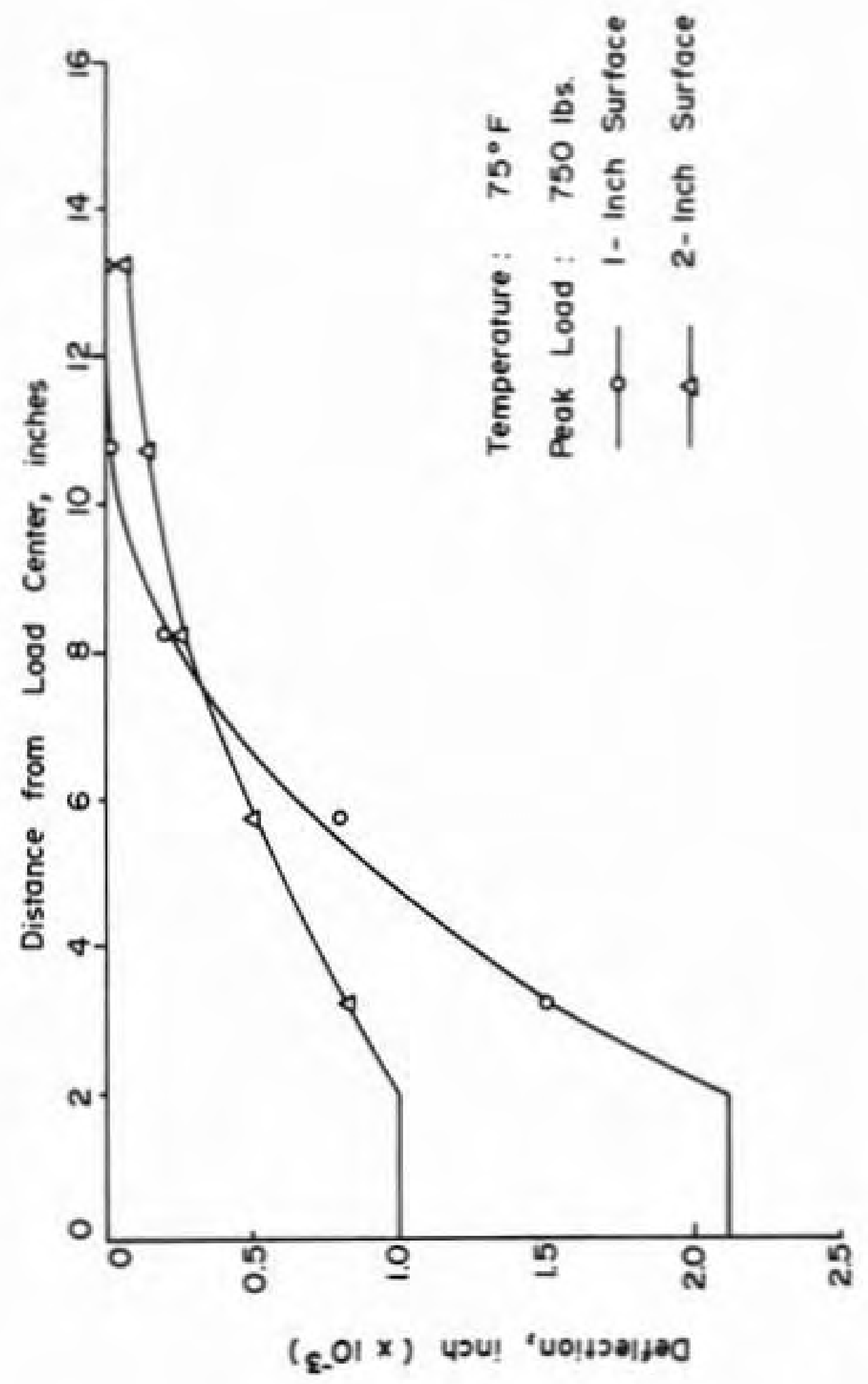

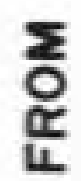

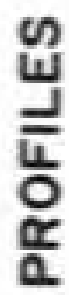

은

눙

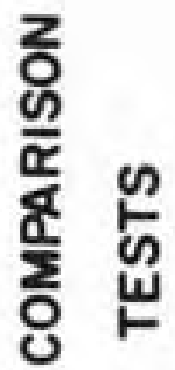

采

$\bar{m}$

$\frac{\text { 峁 }}{\frac{0}{2}}$ 
TABLE 9

VALUES OF $y_{0}$ AND D IN THE EQUATION $y(x)=y_{0} e^{-D x^{2}}$

\begin{tabular}{|c|c|c|c|c|}
\hline Series & in. $\left(\times 10^{-4}\right)$ & $\begin{array}{c}\text { D } \\
1 / \text { in. }^{2} \\
\end{array}$ & $\begin{array}{l}\mathrm{R}^{2} \\
8\end{array}$ & $\begin{array}{c}\text { Number } \\
\text { of } \\
\text { Points }\end{array}$ \\
\hline $1 \mathrm{LI} 1$ & 2.256 & 0.0385 & 99.95 & 5 \\
\hline $1 \mathrm{LI} 2$ & 4.071 & 0.0475 & 99.26 & 5 \\
\hline $1 \mathrm{LI} 3$ & 11.881 & 0.0416 & 99.97 & 5 \\
\hline Average & & 0.0425 & & \\
\hline $1 \mathrm{MI} 1$ & 4.716 & 0.0353 & 99.85 & 5 \\
\hline $1 \mathrm{MI} 2$ & 10.723 & 0.0325 & 99.32 & 5 \\
\hline $1 \mathrm{MI} 3$ & 21.236 & 0.0317 & 99.49 & 5 \\
\hline Average & & 0.0332 & & \\
\hline $1 \mathrm{HI} 1$ & 5.676 & 0.0288 & 99.66 & 10 \\
\hline $1 \mathrm{HI} 2$ & 16.124 & 0.0299 & 99.83 & 5 \\
\hline $1 \mathrm{HI} 3$ & 27.907 & 0.0287 & 99.07 & 10 \\
\hline Average & & 0.0291 & & \\
\hline $2 \mathrm{LI1}$ & 1.066 & 0.0274 & 98.88 & 10 \\
\hline $2 \mathrm{LI} 2$ & 1.959 & 0.0281 & 99.07 & 10 \\
\hline $2 \mathrm{LI} 3$ & 6.106 & 0.0199 & 99.38 & 5 \\
\hline Average & & 0.0251 & & \\
\hline $2 \mathrm{MI} 1$ & 2.254 & 0.0153 & 99.54 & 5 \\
\hline $2 \mathrm{MI} 2$ & 4.437 & 0.0168 & 98.87 & 10 \\
\hline $2 \mathrm{MI} 3$ & 9.997 & 0.0195 & 99.44 & 10 \\
\hline Average & & 0.0172 & & \\
\hline $2 \mathrm{HIl}$ & 4.163 & 0.0176 & 98.85 & 10 \\
\hline $2 \mathrm{HI} 2$ & 8.388 & 0.0172 & 99.11 & 15 \\
\hline $2 \mathrm{HI} 3$ & 14.560 & 0.0149 & 97.88 & 5 \\
\hline Average & & 0.0166 & & \\
\hline
\end{tabular}


0.98 to close to unity. This is an indication that the model chosen to fit the data of deflected profiles is adequate to the task.

It is observed from Figures 25-31 that the portion of the pavement surface under the loading plate was assumed to have experienced a constant displacement at the indicated test conditions. This was a consequence of the use of a rigid loading plate. The choice of the rigid plate itself was made to obtain a distinct trace of load duration during impulse tests.

The effect of temperature on $y_{0}$ is shown in Figures 32 and 33 , respectively, for the model pavements having oneinch and two-inch surface courses. As temperature increases, the less stiff and more responsive the material becomes. Thus, for both model pavements, $y_{0}$ increases with increases in temperature. However, the plots of $y_{0}$ versus temperature do exhibit differences between the two cases. For the oneinch surface, the bottom layers, whose response constitutes most of the total deflection, are less affected by temperature changes than the bituminous surface course and hence the rate of increase in $y_{0}$ decreases with increasing temperature. On the other hand, as the thickness of the asphaltic concrete surface is increased, the influence of the surface layer becomes more pronounced. Inasmuch as the bituminous mixture is more temperature susceptible than the other layer materials, increasing temperature increases the rate of 
85

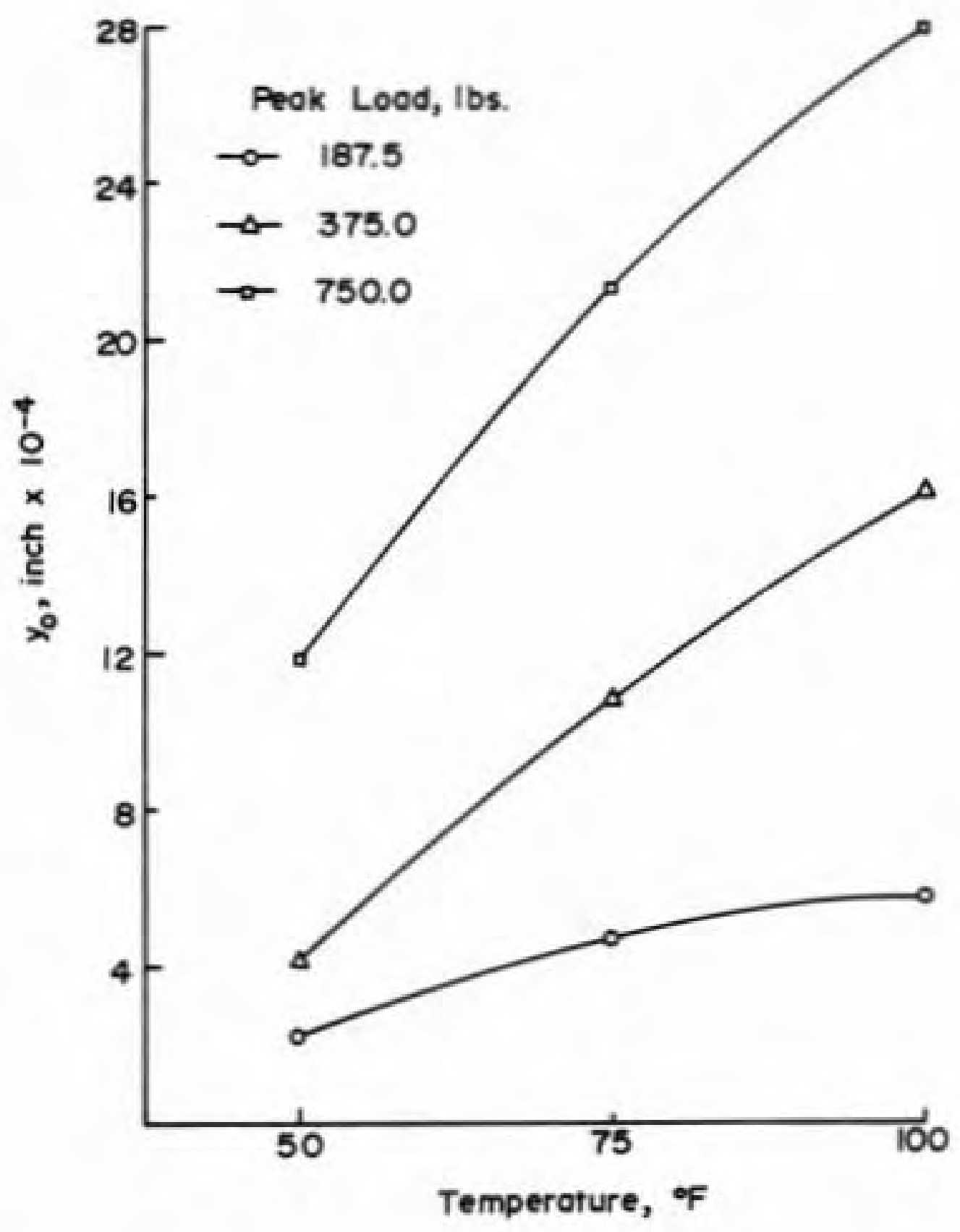

FIGURE $32 y_{0}$ VERSUS TEMPERATURE I- INCH SURFACE 


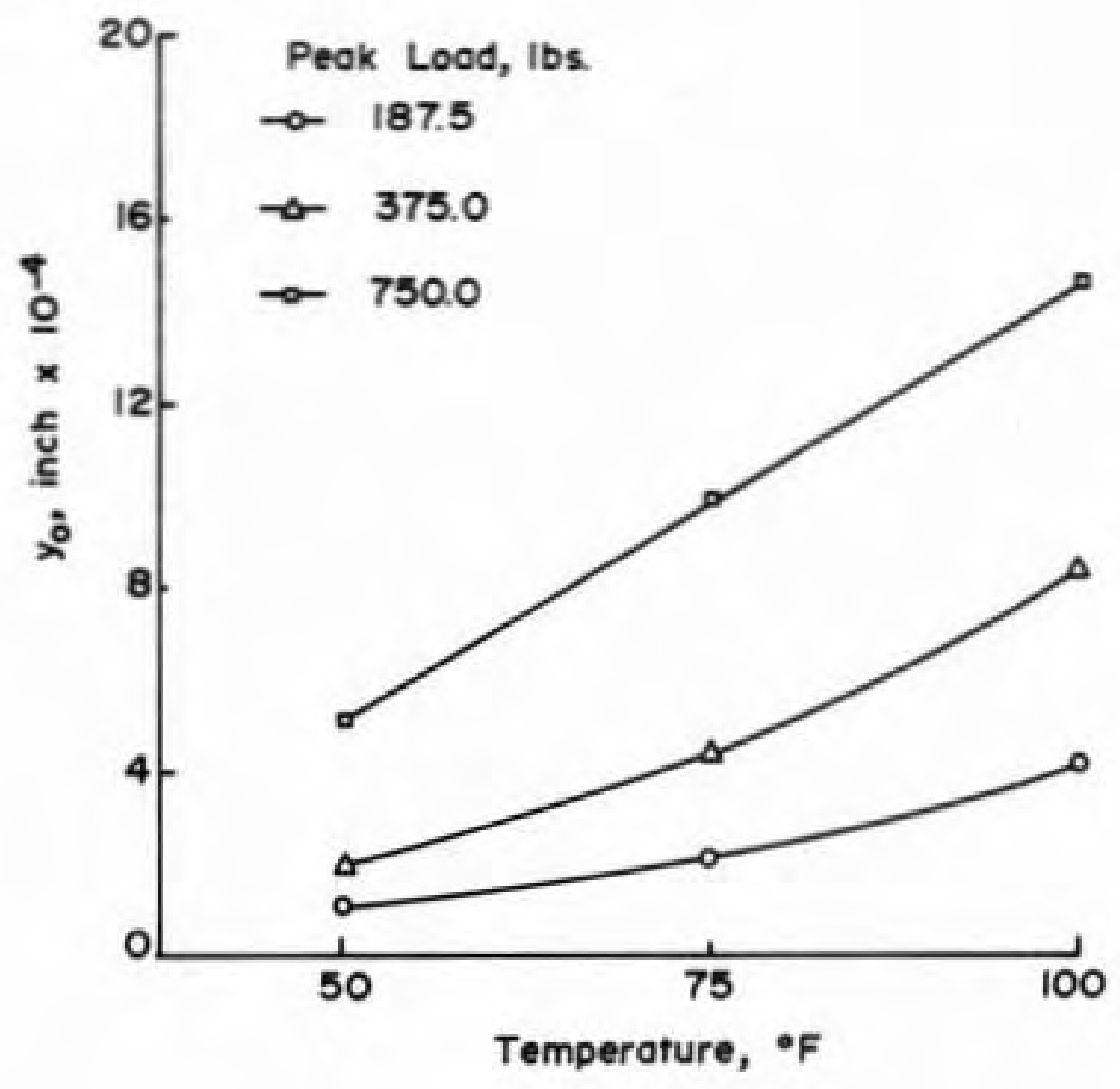

FIGURE 33 Yo VERSUS TEMPERATURE 2-INCH SURFACE 
increase in $y_{0}$. This is also considered as evidence in this investigation that the subgrade and the base course, in addition to the surface layer, responded to the input loads.

Figure 34 depicts the effect of surface course thickness on $y_{0}$ for the three load magnitudes and the three test temperatures. As the temperature increases the slopes of the lines increase, supporting the above discussion about the effect of increasing surface course thickness on $y_{0}$.

The factor D in Equation 32 is a measure of how the deflected basin attenuates with spatial distance $x$. Smaller D values reflect more spreading of the deflection basin. Table 9 indicates that the D parameter does not change appreciably, even though the magnitude of the peak load is increased at any one thickness or temperature. Average values of D versus temperature are plotted in Figure 35 for the two thicknesses. Inasmuch as increases in temperature increase pavement response for a given thickness, attenuation of the deflection basin with $x$ decreases and hence $D$ decreases. The figure also indicates that the slab action is reflected in the parameter D. As the surface course thickness is increased, the deflected basin spreads farther and thus D decreases. It appears from Figure 35 that there is no interaction between the effects of temperature and surface course thickness on D. 


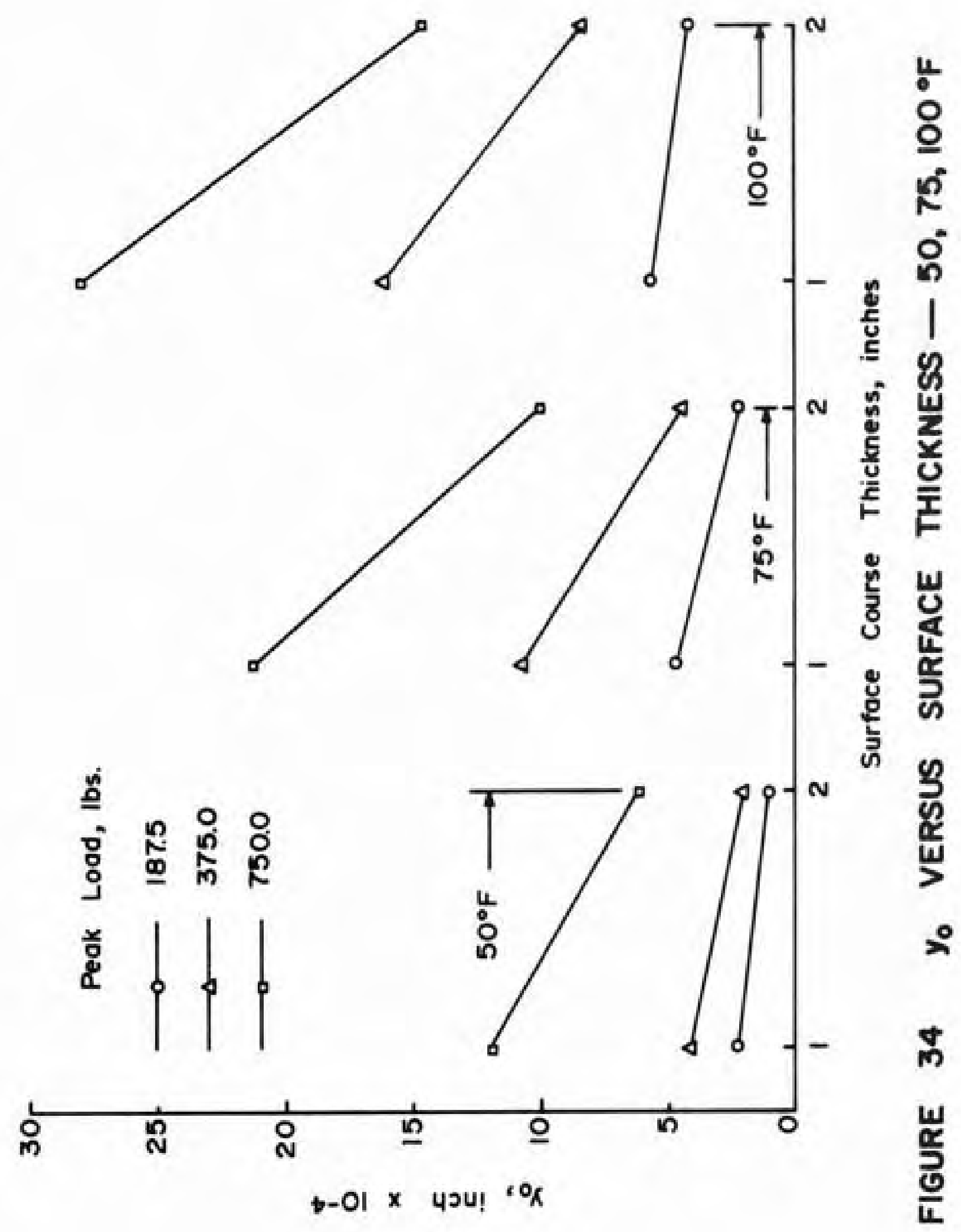




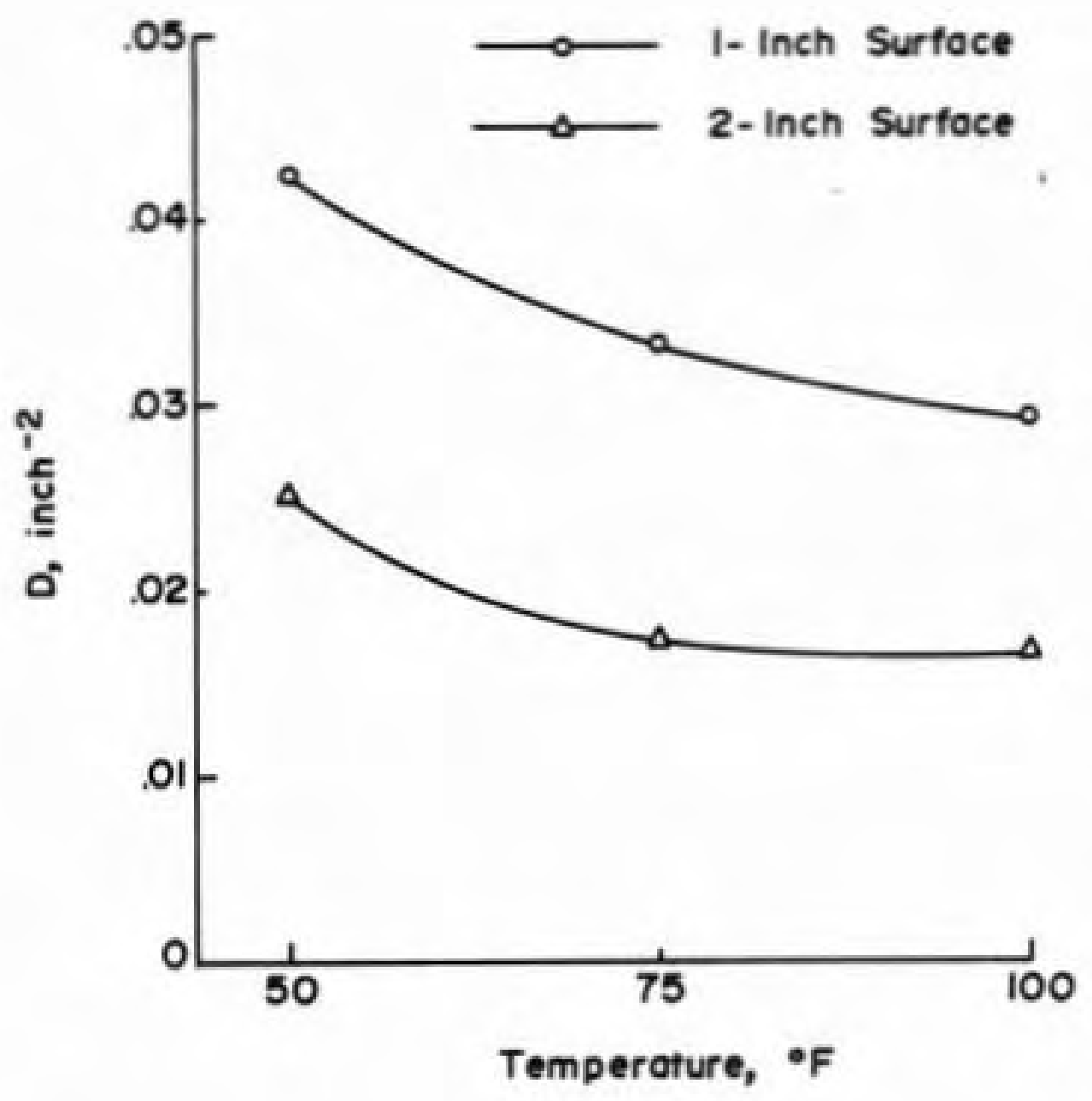

FIGURE 35 D VERSUS TEMPERATURE -

I- INCH, 2-INCH SURFACES 
Response Function of Flexible Pavements

The response functions were calculated from the input load and the output deflection functions using Equation 13. Computations were made by the computer utilizing the subroutine CONVLI of the program listed in Appendix A. The results of the calculations are also shown in Appendix A. For each test series, the table of the input and outputs is followed by the response function table. The three parameters are given as functions of time. The third table in each series is the deflection function predicted by Equation 15 and as computed by subroutine CONVLE.

Typical plots of the input and outputs are shown in Figures 36,37 and 38 , and the corresponding response functions are illustrated in Figures 39,40 and 41 . It is seen that the response functions reach a first peak and then oscillate with time. The peak, in general, occurs in the time band of 0.04 to 0.08 seconds. The general shape of the response functions and the corresponding results agree with those obtained from mechanical models $[45,49,50]$. However, when mechanical models are employed to describe pavement behavior, the parameters must be defined initially, usually in the form of differential equations. Furthermore, no reliable method exists today to determine these parameters "ab initio." This study is characterized by the fact that the response function of a pavement system is determined directly from the input-output data of impulse tests. The 

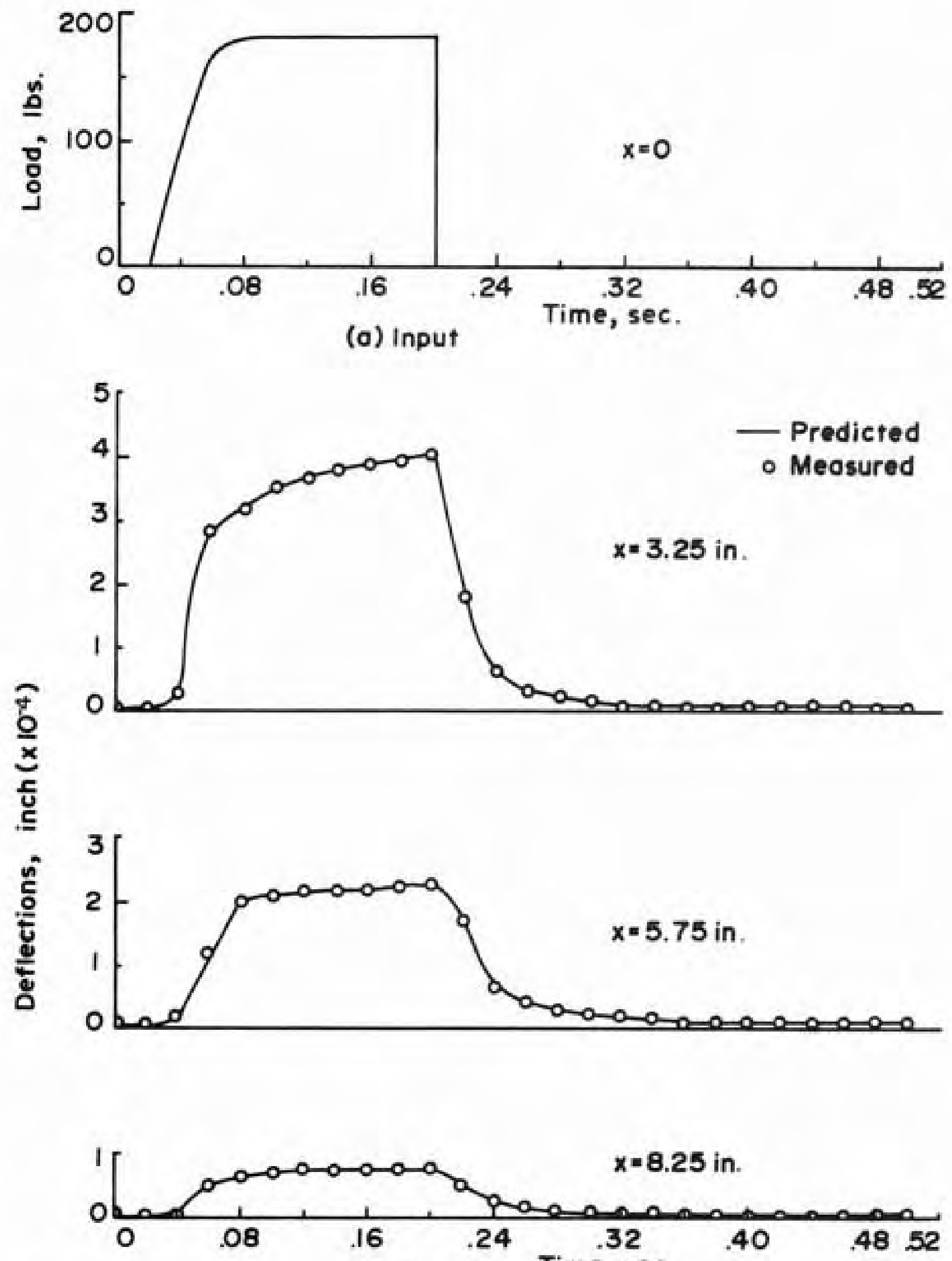

(b) Output Time, sec.

FIGURE 36 INPUT LOAD AND OUTPUT DEFLECTION FUNCTIONS - DATA FOR IHII 

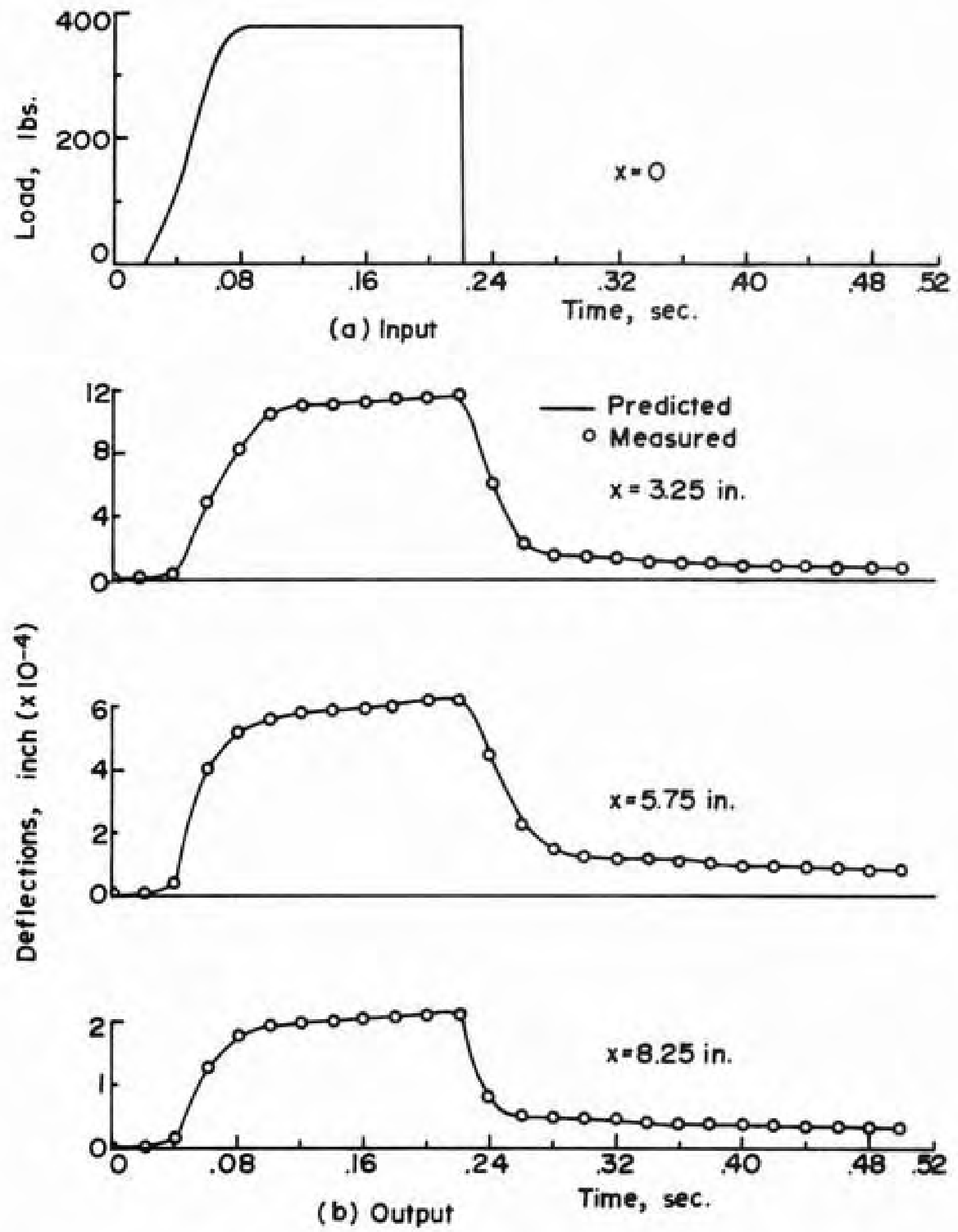

FIGURE 37 INPUT LOAD AND OUTPUT DEFLECTION FUNCTIONS-DATA FOR IHI2 


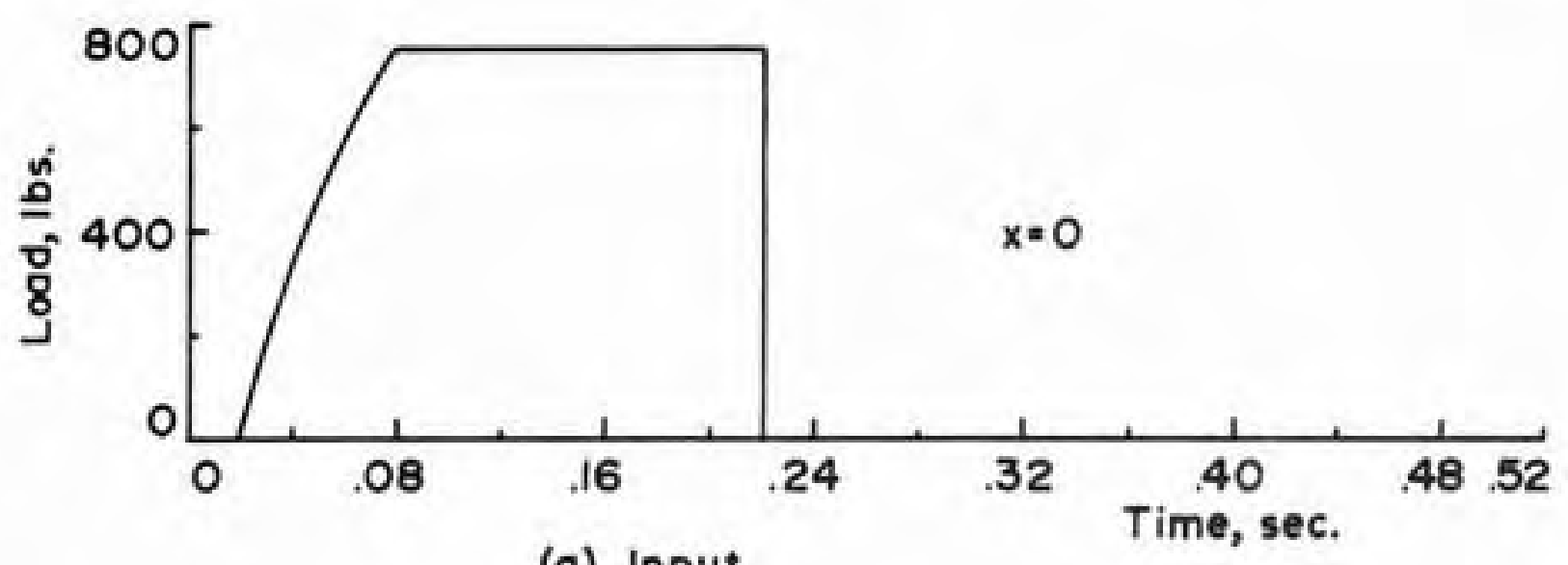

(a) Input
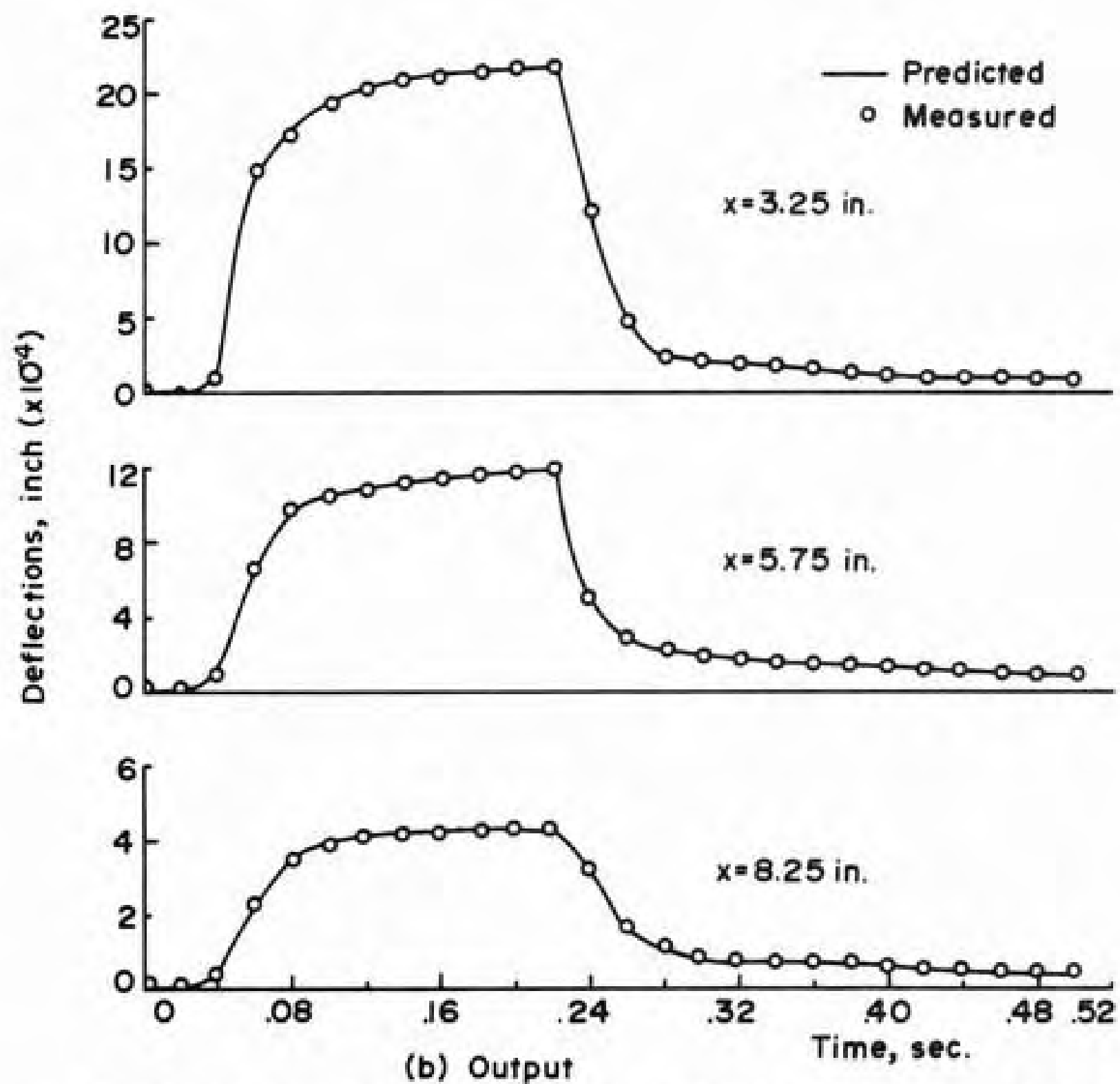

FIGURE 38 INPUT LOAD AND OUTPUT DEFLECTION FUNCTIONS - DATA FOR IHI3 

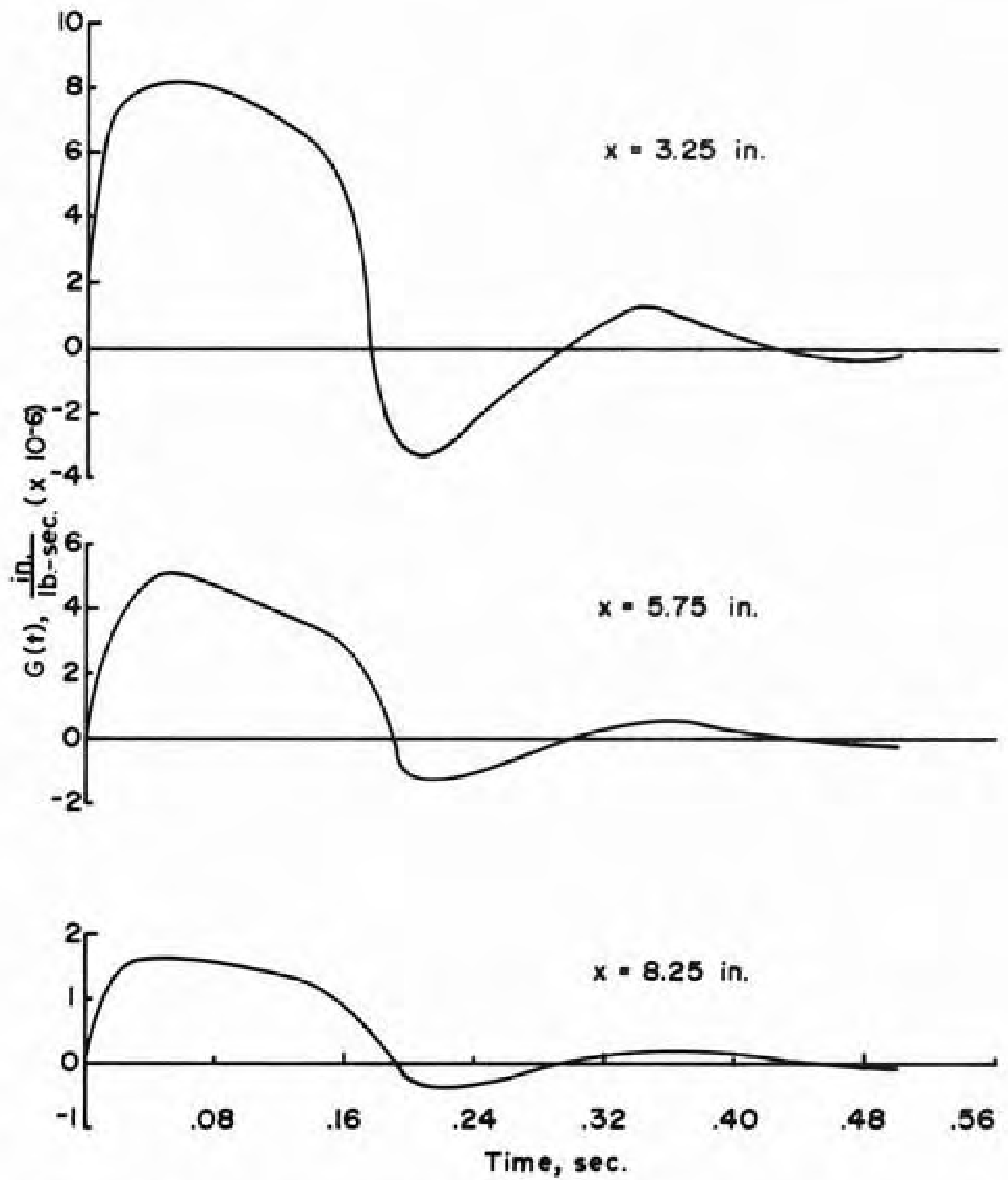

FIGURE 39 RESPONSE FUNCTIONS - DATA FROM IHII 

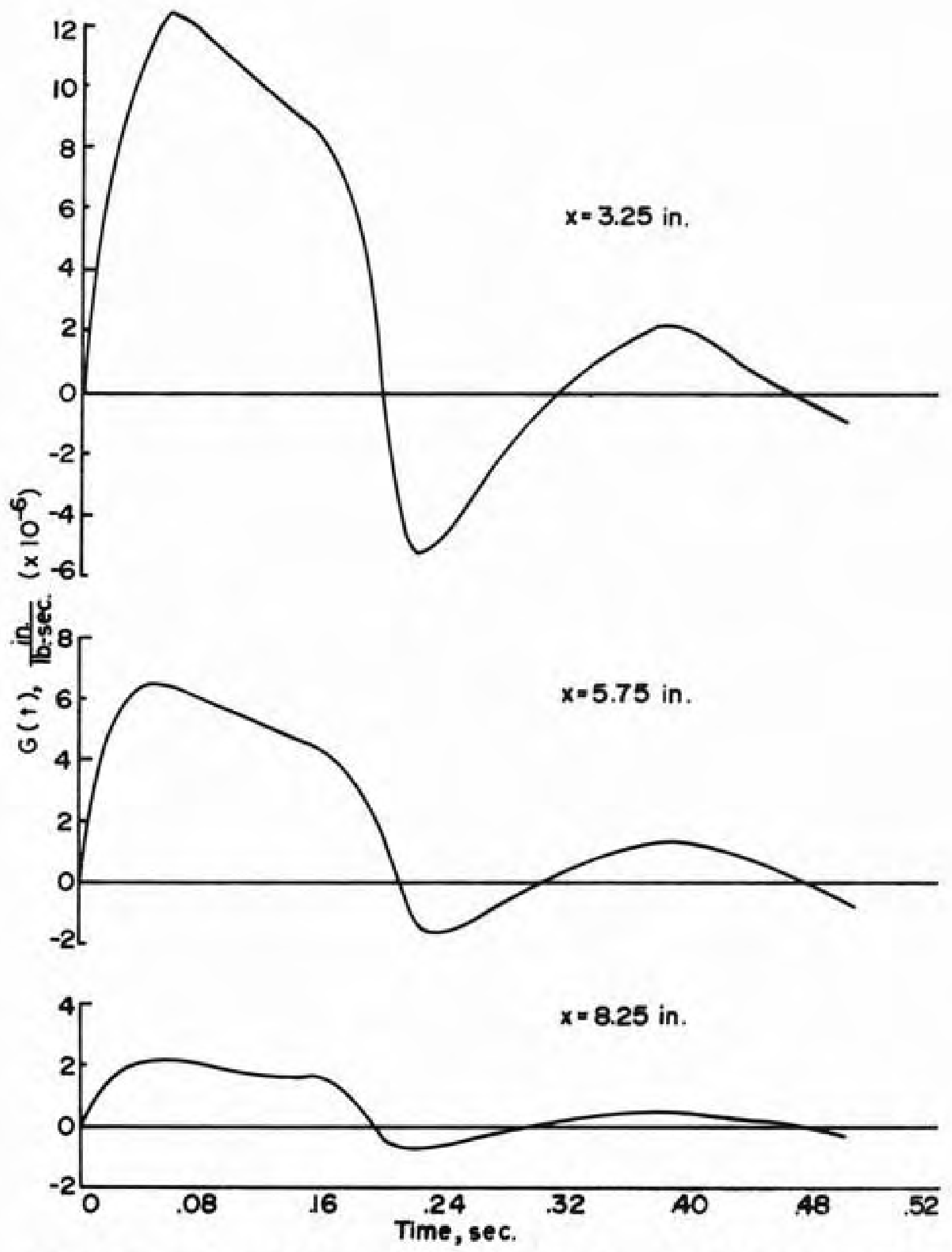

FIGURE 40 RESPONSE FUNCTIONS - DATA FROM IHI2 


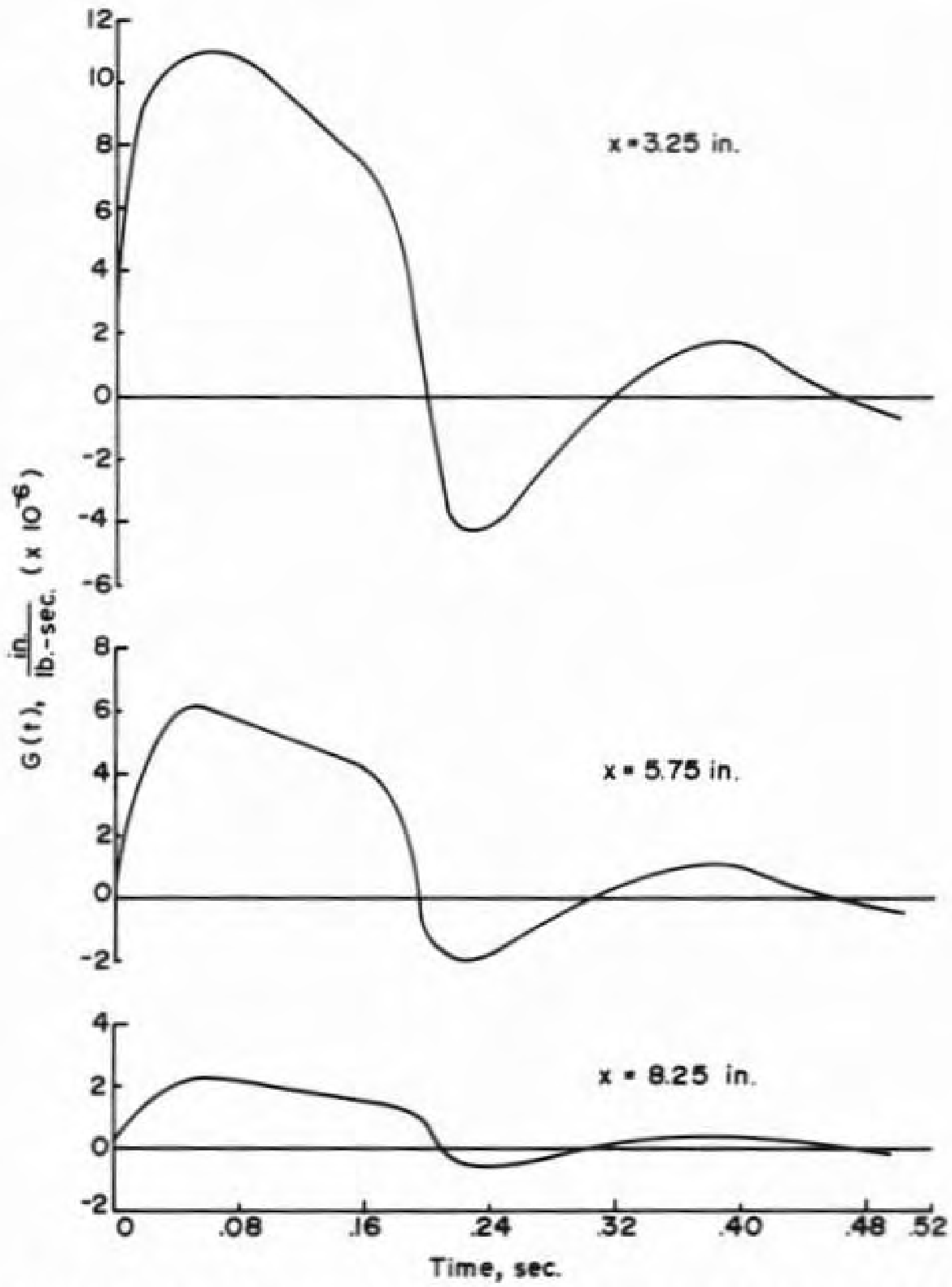

FIGURE 4I RESPONSE FUNCTIONS-DATA FROM IHI3 
consistency of the response functions obtained in this study appears to validate the first assumption that "a determinable relationship exists between known input and output of a pavement system."

Form of the Response Function

Some typical response functions are represented in Figures 39,40 and 41 for the indicated test conditions. In the interest of obtaining more information about pavement response functions and to provide a rational interpretation of the results, the response function curves were approximated by the mathematical model

$$
G(t)=\alpha e^{-\beta t} \sin \gamma t
$$

where $\alpha, \beta$ and $\gamma$ are parameters to be determined by a nonlinear regression analysis. The results of the analysis are shown in Tables 10,11 and 12 . It is seen from these tables that the squared correlation coefficient $\left(R^{2}\right)$ ranged from 66 to 93 percent.

From the technique followed in approximating the response function curve, it is obvious that the number of parameters required to describe the response function depends on the model selected. As the number of parameters in the model increases, the accuracy of curve-fitting improves and, consequently, the value of $\mathrm{R}^{2}$ increases. 
TABLE 10

DESCRIPTIVE PARAMETERS IN THE RESPONSE FUNCTIONS AT $50^{\circ} \mathrm{F}$

$$
G(t)=\alpha e^{-\beta t} \sin \gamma t
$$

\begin{tabular}{|c|c|c|c|c|c|c|}
\hline $\begin{array}{l}\text { Thick- } \\
\text { ness } \\
\text { in. }\end{array}$ & in. & $\mathrm{F}_{\mathrm{p}}$ & $\begin{array}{c}\alpha \\
\frac{\text { in. }}{1 \mathrm{~b}-\mathrm{sec} .} \\
\times 10^{-6}\end{array}$ & $\frac{1}{\sec .}$ & $\begin{array}{c}\gamma \\
\frac{1}{\sec .}\end{array}$ & $\mathrm{R}^{2}$ \\
\hline \multirow[t]{3}{*}{1} & 3.25 & $\begin{array}{r}375.0 \\
750.0 \\
\text { Average }\end{array}$ & $\begin{array}{r}6.86 \\
10.40 \\
8.63\end{array}$ & $\begin{array}{l}10.764 \\
10.551 \\
10.658\end{array}$ & $\begin{array}{l}13.382 \\
15.848 \\
14.615\end{array}$ & $\begin{array}{l}85.73 \\
87.48\end{array}$ \\
\hline & 5.75 & $\begin{array}{r}375.0 \\
750.0 \\
\text { Average }\end{array}$ & $\begin{array}{l}1.36 \\
3.60 \\
2.48\end{array}$ & $\begin{array}{l}7.127 \\
8.784 \\
7.956\end{array}$ & $\begin{array}{l}14.593 \\
17.285 \\
15.939\end{array}$ & $\begin{array}{l}78.09 \\
86.79\end{array}$ \\
\hline & 8.25 & $\begin{array}{r}375.0 \\
750.0 \\
\text { Average }\end{array}$ & $\begin{array}{l}0.48 \\
0.72 \\
0.60\end{array}$ & $\begin{array}{l}6.140 \\
8.195 \\
7.168\end{array}$ & $\begin{array}{l}14.470 \\
15.716 \\
15.093\end{array}$ & $\begin{array}{l}75.86 \\
86.32\end{array}$ \\
\hline \multirow[t]{3}{*}{2} & 3.25 & $\begin{array}{r}187.5 \\
375.0 \\
750.0 \\
\text { Average }\end{array}$ & $\begin{array}{l}5.39 \\
3.57 \\
5.39 \\
4.78\end{array}$ & $\begin{array}{r}12.879 \\
9.847 \\
8.785 \\
10.504\end{array}$ & $\begin{array}{l}12.336 \\
12.709 \\
16.018 \\
13.688\end{array}$ & $\begin{array}{l}92.39 \\
87.60 \\
84.34\end{array}$ \\
\hline & 5.75 & $\begin{array}{r}187.5 \\
375.0 \\
750.0 \\
\text { Average }\end{array}$ & $\begin{array}{l}2.41 \\
1.70 \\
3.51 \\
2.54\end{array}$ & $\begin{array}{r}11.302 \\
7.517 \\
7.540 \\
8.786\end{array}$ & $\begin{array}{l}14.222 \\
12.988 \\
16.406 \\
14.539\end{array}$ & $\begin{array}{l}83.88 \\
83.16 \\
84.82\end{array}$ \\
\hline & 8.25 & $\begin{array}{r}187.5 \\
375.0 \\
750.0 \\
\text { Average }\end{array}$ & $\begin{array}{l}0.70 \\
0.51 \\
1.56 \\
0.92\end{array}$ & $\begin{array}{l}9.610 \\
7.409 \\
8.792 \\
8.604\end{array}$ & $\begin{array}{l}12.598 \\
12.996 \\
16.824 \\
14.139\end{array}$ & $\begin{array}{l}65.68 \\
73.44 \\
83.86\end{array}$ \\
\hline
\end{tabular}


TABLE 11

DESCRIPTIVE PARAMETERS IN THE RESPONSE FUNCTIONS AT $75^{\circ} \mathrm{F}$

$$
G(t)=\alpha e^{-\beta t} \sin \gamma t
$$

\begin{tabular}{|c|c|c|c|c|c|c|}
\hline $\begin{array}{l}\text { Thick- } \\
\text { ness } \\
\text { in. }\end{array}$ & $\begin{array}{c}x \\
\text { in. }\end{array}$ & $\begin{array}{l}\mathrm{F}_{\mathrm{p}} \\
1 \mathrm{bs} .\end{array}$ & $\begin{array}{c}\frac{a}{\text { in. }} \\
\frac{1 b .-\sec }{\times 10^{-6}}\end{array}$ & $\begin{array}{l}\beta \\
\frac{1}{\sec .}\end{array}$ & $\begin{array}{c}Y \\
\frac{1}{\sec .}\end{array}$ & $\begin{array}{l}\mathrm{R}^{2} \\
8\end{array}$ \\
\hline \multirow[t]{3}{*}{1} & 3.25 & $\begin{array}{r}187.5 \\
375.0 \\
750.0 \\
\text { Average }\end{array}$ & $\begin{array}{l}21.28 \\
21.89 \\
24.61 \\
22.59\end{array}$ & $\begin{array}{l}12.604 \\
11.537 \\
12.348 \\
12.163\end{array}$ & $\begin{array}{l}13.875 \\
14.989 \\
13.752 \\
14.205\end{array}$ & $\begin{array}{l}88.26 \\
86.00 \\
87.44\end{array}$ \\
\hline & 5.75 & $\begin{array}{r}187.5 \\
375.0 \\
750.0 \\
\text { Average }\end{array}$ & $\begin{array}{l}10.31 \\
13.73 \\
14.42 \\
12.82\end{array}$ & $\begin{array}{l}13.079 \\
12.908 \\
13.084 \\
13.024\end{array}$ & $\begin{array}{l}12.791 \\
13.496 \\
12.478 \\
12.922\end{array}$ & $\begin{array}{l}85.77 \\
88.41 \\
89.07\end{array}$ \\
\hline & 8.25 & $\begin{array}{r}187.5 \\
375.0 \\
750.0 \\
\text { Average }\end{array}$ & $\begin{array}{l}2.08 \\
2.52 \\
3.51 \\
2.70\end{array}$ & $\begin{array}{l}10.434 \\
11.177 \\
13.199 \\
11.603\end{array}$ & $\begin{array}{l}11.703 \\
15.026 \\
13.934 \\
13.554\end{array}$ & $\begin{array}{l}87.44 \\
87.98 \\
87.35\end{array}$ \\
\hline \multirow[t]{3}{*}{2} & 3.25 & $\begin{array}{r}187.5 \\
375.0 \\
750.0 \\
\text { Average }\end{array}$ & $\begin{array}{r}9.49 \\
7.98 \\
12.26 \\
9.91\end{array}$ & $\begin{array}{r}9.500 \\
8.232 \\
11.000 \\
9.577\end{array}$ & $\begin{array}{l}13.868 \\
12.914 \\
15.272 \\
14.351\end{array}$ & $\begin{array}{l}90.80 \\
88.23 \\
88.52\end{array}$ \\
\hline & 5.75 & $\begin{array}{r}187.5 \\
375.0 \\
750.0 \\
\text { Average }\end{array}$ & $\begin{array}{l}6.97 \\
4.97 \\
9.17 \\
7.04\end{array}$ & $\begin{array}{r}9.525 \\
7.164 \\
13.347 \\
10.012\end{array}$ & $\begin{array}{l}14.191 \\
14.398 \\
14.020 \\
14.203\end{array}$ & $\begin{array}{l}90.31 \\
81.43 \\
89.63\end{array}$ \\
\hline & 8.25 & $\begin{array}{r}187.5 \\
375.0 \\
750.0 \\
\text { Average }\end{array}$ & $\begin{array}{l}4.21 \\
3.53 \\
3.73 \\
3.82\end{array}$ & $\begin{array}{r}10.523 \\
9.195 \\
11.471 \\
10.396\end{array}$ & $\begin{array}{l}13.452 \\
14.479 \\
15.260 \\
14.397\end{array}$ & $\begin{array}{l}92.32 \\
91.03 \\
87.63\end{array}$ \\
\hline
\end{tabular}


TABLE 12

DESCRIPTIVE PARAMETERS IN THE RESPONSE FUNCTIONS AT $100^{\circ} \mathrm{F}$

$$
G(t)=\alpha e^{-\beta t} \sin \gamma t
$$

\begin{tabular}{|c|c|c|c|c|c|c|}
\hline $\begin{array}{l}\text { Thick- } \\
\text { ness } \\
\text { in. }\end{array}$ & in. & $\begin{array}{l}\mathrm{F}_{\mathrm{p}} \\
1 \mathrm{bs} .\end{array}$ & 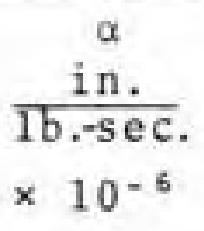 & $\frac{1}{\sec .}$ & $\begin{array}{c}\gamma \\
\frac{1}{\sec .}\end{array}$ & $\mathrm{R}^{2}$ \\
\hline \multirow[t]{3}{*}{1} & 3.25 & $\begin{array}{r}180.0 \\
375.0 \\
750.0 \\
\text { Average }\end{array}$ & $\begin{array}{l}19.33 \\
26.03 \\
26.30 \\
23.89\end{array}$ & $\begin{array}{l}8.953 \\
7.950 \\
8.633 \\
8.512\end{array}$ & $\begin{array}{l}16.968 \\
15.353 \\
15.334 \\
15.885\end{array}$ & $\begin{array}{l}84.62 \\
83.28 \\
84.30\end{array}$ \\
\hline & 5.75 & $\begin{array}{r}180.0 \\
375.0 \\
750.0 \\
\text { Average }\end{array}$ & $\begin{array}{l}12.35 \\
22.13 \\
14.93 \\
16.47\end{array}$ & $\begin{array}{r}10.044 \\
12.506 \\
9.478 \\
10.676\end{array}$ & $\begin{array}{l}15.383 \\
12.335 \\
14.911 \\
14.210\end{array}$ & $\begin{array}{l}88.75 \\
82.95 \\
81.78\end{array}$ \\
\hline & 8.25 & $\begin{array}{r}180.0 \\
375.0 \\
750.0 \\
\text { Average }\end{array}$ & $\begin{array}{l}4.41 \\
6.15 \\
6.46 \\
5.67\end{array}$ & $\begin{array}{l}10.523 \\
10.951 \\
10.659 \\
10.711\end{array}$ & $\begin{array}{l}15.061 \\
14.452 \\
12.977 \\
14.163\end{array}$ & $\begin{array}{l}88.57 \\
78.24 \\
85.20\end{array}$ \\
\hline \multirow[t]{3}{*}{2} & 3.25 & $\begin{array}{r}187.5 \\
375.0 \\
750.0 \\
\text { Average }\end{array}$ & $\begin{array}{l}17.54 \\
23.25 \\
19.33 \\
20.04\end{array}$ & $\begin{array}{l}11.273 \\
13.187 \\
12.960 \\
12.473\end{array}$ & $\begin{array}{l}14.046 \\
13.870 \\
12.700 \\
13.539\end{array}$ & $\begin{array}{l}83.11 \\
86.90 \\
80.87\end{array}$ \\
\hline & 5.75 & $\begin{array}{r}187.5 \\
375.0 \\
750.0 \\
\text { Average }\end{array}$ & $\begin{array}{l}10.89 \\
11.08 \\
15.66 \\
12.54\end{array}$ & $\begin{array}{r}9.051 \\
8.779 \\
12.068 \\
9.966\end{array}$ & $\begin{array}{l}14.274 \\
12.825 \\
13.983 \\
13.694\end{array}$ & $\begin{array}{l}87.87 \\
89.93 \\
89.15\end{array}$ \\
\hline & 8.25 & $\begin{array}{r}187.5 \\
375.0 \\
750.0 \\
\text { Average }\end{array}$ & $\begin{array}{l}4.56 \\
7.46 \\
6.68 \\
6.23\end{array}$ & $\begin{array}{r}8.202 \\
11.846 \\
11.081 \\
10.376\end{array}$ & $\begin{array}{l}13.798 \\
11.680 \\
13.015 \\
12.831\end{array}$ & $\begin{array}{l}84.81 \\
92.34 \\
93.19\end{array}$ \\
\hline
\end{tabular}


Check for the Response Function

The response functions determined from the input-output data of the impulse tests were verified employing Equation 15. Essentially, this equation uses the impulse load input and the derived response function for a particular case. Computations result in the deflection function which was previously used to obtain the response function. Hence, the predicted deflection function should match the corresponding measured value. This checking procedure was applied to al1 the response functions as shown in Appendix A. The agreement was observed to be close to perfect. Typical plots are illustrated in Figures 36,37 and 38 . Table 13 shows the predicted and measured values for Series 1 HI 3 as a typical illustration.

Load-Independency of the Response Function

In this investigation, the response functions for almost al1 cases* were determined at three different peak stress leve1s, namely $14.93,29.86$ and 59.72 psi designated respectively, by the numbers 1,2 and 3 in the data coding system. It was found that the response functions derived at these stress levels for any test condition, that is at the same surface course thickness, temperature and spatial location, did not change significantly. Comparisons of representative

* The response functions for the 1 LI1 Series were not determined because the deflection functions were not clearly recorded. Only the peak deflection values are included in the analysis of test results. 
TABLE 13

TYPICAL PREDICTED AND MEASURED DEFLECTION FUNCTIONS

Series: $1 \mathrm{HI} 3$

\begin{tabular}{|c|c|c|c|c|c|c|}
\hline \multirow{4}{*}{$\begin{array}{l}\text { Time } \\
\text { sec. }\end{array}$} & \multirow{2}{*}{\multicolumn{6}{|c|}{$\begin{array}{l}\text { Deflection Functions, inch }\left(\times 10^{-4}\right) \\
\text { Distance from Load Center inches }\end{array}$}} \\
\hline & & & & & & \\
\hline & \multicolumn{2}{|c|}{3.25} & \multicolumn{2}{|c|}{5.75} & \multicolumn{2}{|c|}{8.25} \\
\hline & Pred. & Meas. & Pred. & Meas. & Pred. & Meas. \\
\hline 0 & 0 & 0 & 0 & 0 & 0 & 0 \\
\hline 0.02 & 0 & 0 & 0 & 0 & 0 & 0 \\
\hline 0.04 & 0.90 & 0.90 & 0.80 & 0.80 & 0.40 & 0.40 \\
\hline 0.06 & 15.00 & 15.00 & 6.40 & 6.40 & 2.24 & 2.24 \\
\hline 0.08 & 17.10 & 17.10 & 9.60 & 9.60 & 3.44 & 3.44 \\
\hline 0.10 & 19.50 & 19.50 & 10.40 & 10.40 & 3.88 & 3.88 \\
\hline 0.12 & 20.40 & 20.40 & 10.72 & 10.72 & 4.08 & 4.08 \\
\hline 0.14 & 21.00 & 21.00 & 11.04 & 11.04 & 4.12 & 4.12 \\
\hline 0.16 & 21.15 & 21.15 & 11.20 & 11.20 & 4.16 & 4.16 \\
\hline 0.18 & 21.30 & 21.30 & 11.52 & 11.52 & 4.24 & 4.24 \\
\hline 0.20 & 21.60 & 21.60 & 11.68 & 11.68 & 4.28 & 4.28 \\
\hline 0.22 & 21.75 & 21.75 & 11.84 & 11.84 & 4.32 & 4.32 \\
\hline 0.24 & 12.00 & 12.00 & 4.80 & 4.80 & 3.20 & 3.20 \\
\hline 0.26 & 4.50 & 4.50 & 2.80 & 2.80 & 1.60 & 1.60 \\
\hline 0.28 & 2.40 & 2.40 & 2.08 & 2.08 & 1.12 & 1.12 \\
\hline 0.30 & 2.10 & 2.10 & 1.76 & 1.76 & 0.80 & 0.80 \\
\hline 0.32 & 1.80 & 1.80 & 1.60 & 1.60 & 0.76 & 0.76 \\
\hline 0.34 & 1.65 & 1.65 & 1.52 & 1.52 & 0.72 & 0.72 \\
\hline 0.36 & 1.50 & 1. 50 & 1.44 & 1.44 & 0.64 & 0.64 \\
\hline 0.38 & 1.20 & 1.20 & 1.36 & 1.36 & 0.60 & 0.60 \\
\hline 0.40 & 1.05 & 1.05 & 1.20 & 1.20 & 0.56 & 0.56 \\
\hline 0.42 & 0.90 & 0.90 & 1.12 & 1.12 & 0.52 & 0.52 \\
\hline 0.44 & 0.90 & 0.90 & 1.04 & 1.04 & 0.48 & 0.48 \\
\hline 0.46 & 0.90 & 0.90 & 0.96 & 0.96 & 0.44 & 0.44 \\
\hline 0.48 & 0.90 & 0.90 & 0.88 & 0.88 & 0.44 & 0.44 \\
\hline 0.50 & 0.90 & 0.90 & 0.88 & 0.88 & 0.44 & 0.44 \\
\hline
\end{tabular}


plots of the response functions illustrated in Figures 39, 40 , and 41 support this observation. Table 14 summarizes the first positive peak, the time of its occurrence, the first negative peak and the time of its occurrence for each of these response functions. It is evident from this table that these four parameters do not change significantly as the peak impulse load $\mathrm{F}_{\mathrm{p}}$ is changed at any spatial location considered.

Inasmuch as the parameters in Equation 14 approximately represent the respective response function curve, the values of the $\alpha, \beta$ and $\gamma$ parameters shown in Tables 10,11 and 12 are examined to further demonstrate the load-independency of the response functions. It is seen from these tables that the $\alpha, \beta$ and $\gamma$ parameters for each case do not vary appreciably as the magnitude of load changes. One exception with a distinct variability is evident in Table 10, and that is the magnitude of $\alpha$ for the one-inch surface when $x$ is equal to 8.25 inches and the load is $7501 \mathrm{bs}$. It is possible that this discrepancy may be reduced if more parameters are included in the curve fitting process.

From the above discussion it is seen to be feasible to use the average values for $\alpha, \beta$ and $\gamma$ in order to study the effect on these parameters of the other test variables. This is the subject of the next two sections. 
TABLE 14

COMPARISON OF RESPONSE FUNCTIONS

OBTAINED FROM DIFFERENT LOAD MAGNITUDES

\begin{tabular}{|c|c|c|c|c|c|}
\hline & Surface & \multicolumn{2}{|c|}{$\begin{array}{l}\text { Course Thickness: } \\
\text { Test Tenperature: }\end{array}$} & \multicolumn{2}{|l|}{$\begin{array}{l}1 \text { inch } \\
100^{\circ} \mathrm{F}\end{array}$} \\
\hline \multirow{3}{*}{$\begin{array}{c}x \\
\text { inches }\end{array}$} & \multirow{3}{*}{$\begin{array}{l}\mathrm{F}_{\mathrm{p}} \\
1 \mathrm{bs} .\end{array}$} & \multicolumn{2}{|c|}{ First Positive Peak } & \multicolumn{2}{|c|}{ First Negative Peak } \\
\hline & & Magnitude & Tine & Magnitude & Tine \\
\hline & & $\frac{\text { in. }}{1 \mathrm{~b} \cdot-\mathrm{sec} .} \times 10^{-6}$ & sec. & $\frac{\text { in. }}{16 .-\sec .} \times 10^{-5}$ & sec. \\
\hline \multirow[t]{3}{*}{3.25} & 180.0 & 8.40 & 0.06 & -3.32 & 0.20 \\
\hline & 375.0 & 12.48 & 0.06 & -5.25 & 0.22 \\
\hline & 750.0 & 11.10 & 0.06 & -4.37 & 0.22 \\
\hline \multirow[t]{3}{*}{5.75} & 180.0 & 5.19 & 0.04 & -1.31 & 0.22 \\
\hline & 375.0 & 6.46 & 0.04 & -1.64 & 0.24 \\
\hline & 750.0 & 6.01 & 0.04 & -2.06 & 0.22 \\
\hline \multirow[t]{3}{*}{8.25} & 180.0 & 1.64 & 0.06 & -0.38 & 0.22 \\
\hline & 375.0 & 2.19 & 0.06 & -0.76 & 0.22 \\
\hline & 750.0 & 2.24 & 0.06 & -0.54 & 0.24 \\
\hline
\end{tabular}


Effect of Temperature on the Response Function The parameters $\alpha, \beta$ and $\gamma$ are, respectively, measures of the peak of the response function $G(t)$ and of how $G(t)$ varies with time. As such, $\alpha$ can be regarded as representing the stiffness characteristic of a pavement system, whereas $\beta$ and $\gamma$ reflect the damping characteristics of the system. Pavement materials having large $\alpha$ values will provide less resistance to imposed loads.

Referring to the curves of $\alpha$ versus temperature shown in Figure 42 , it is readily apparent that temperature plays an important role in the response function of pavement systems. It was mentioned elsewhere that flexible pavement components, and asphaltic concrete in particular, are thermoplastic. They yield increased response for increases in temperature, other test variables being the same, and hence yield increased $\alpha$ values. This trend is indicated by the curves of Figure 42 .

Examination of the parameters in Tables 10, 11 and 12 reveals that changes in $\beta$ and $\gamma$ are small as temperature changes. This is possibly due to the fact that no significant change is observed in the shapes of the response function curves. Furthermore, the slight variations in the values of these parameters are not critical since they appear, respectively, as exponential and sinusoidal functions in the response function model (Equation 14). 


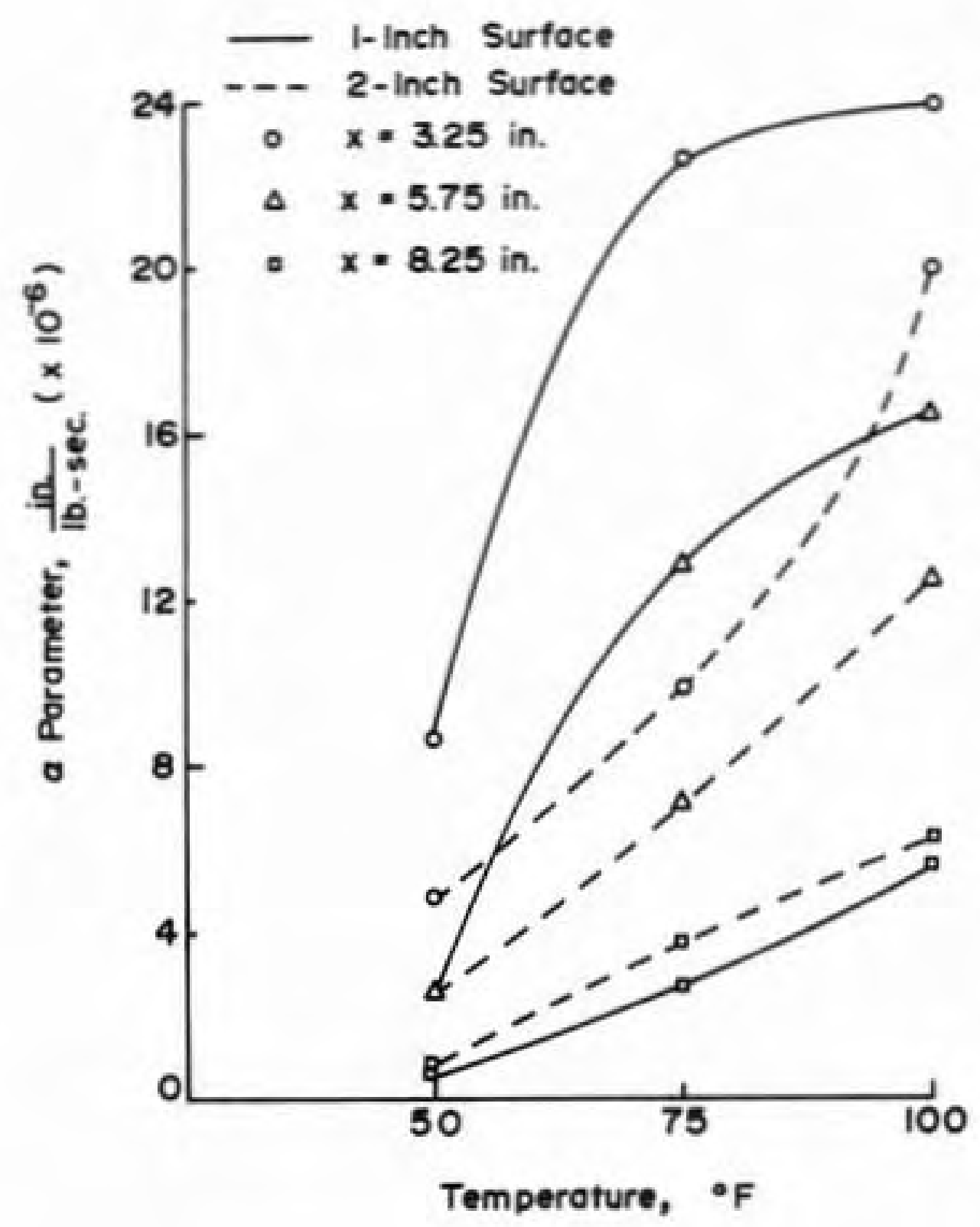

FIGURE 42 CURVES OF a PARAMETER VERSUS TEMPERATURE 
Effects of Thickness and Spatial Location

From the graphical results shown in Figure 42 , it is observed that at $x$ equals 3.25 and 5.75 inches, the value of $\alpha$ decreases with increases in surface course thickness at a11 temperatures. However, at $x$ equals 8.25 inches $\alpha$ increases with increases in thickness. This trend reflects the slab-like action of the system that a thicker pavement responds more at remote locations than a thinner one. Further examination of the figure shows that the curves indicate the interaction between surface course thickness and temperature. For the one-inch surface the rate of increase in a decreases with increases in temperature, whereas this rate is increased for the two-inch surface. It is recalled that similar observations were made previously regarding the effects of temperature and surface course thickness on the central deflection $y_{0}$. Obviously, the value of $\alpha$ decreases with increasing values of $x$, thus depicting the attenuation of the magnitude of $\alpha$ with spatial location. Referring to Tables 10,11 and 12 , it is seen that the values of the parameters $\beta$ and $\gamma$ remain approximately constant with changes in the surface course and/or spatial location. This, again, is probably due to the similarity of the shapes of the response function curves.

\section{Static Load Results}

Static load deflections $y(t)$ were calculated using Equation 23 of "Solution for Step Loading." Computations 
were carried out employing the computer program STALOD listed in Appendix B. The predicted deflections and the corresponding measured values for all test series are summarized in Table 15. Typical plots are illustrated in Figures 43,44 and 45 . C1ose agreement in almost al1 cases is indicated in this table. It is very significant at this stage to recapitulate what has been done:

1. Pavement parameters were determined from inpulse load tests.

2. The derived parameters were used in conjunction with a formulated theory to predict static load deflections for various test conditions of temperature, surface course thickness and spatial location.

3. The agreement between predicted and measured values was observed to be tolerable within experimental error.

Thus, the following conclusions, which will further be supported by the results and discussions of the next section, can be made:

1. The pavement parameters obtained in this investigation are indeed descriptors of pavement behavior.

2. Inasmuch as the two types of loads are different, one being dynamic and the other static, these parameters are independent of the type of input load. 
TABLE 15

PREDICTED AND MEASURED STATIC LOAD DEFLECTIONS

\begin{tabular}{|c|c|c|c|c|c|c|c|c|}
\hline \multirow{4}{*}{$\begin{array}{l}\text { Thick- } \\
\text { ness } \\
\text { in. }\end{array}$} & \multirow{4}{*}{$\begin{array}{l}\text { Temp. } \\
{ }^{\circ} \mathrm{F}\end{array}$} & \multirow{4}{*}{$\begin{array}{l}\mathrm{F}_{\mathrm{o}} \\
1 \mathrm{bs} .\end{array}$} & \multicolumn{6}{|c|}{$y(t)$, inch $\left(\times 10^{-4}\right)$} \\
\hline & & & \multicolumn{6}{|c|}{ Distance from Load Center, inches } \\
\hline & & & \multicolumn{2}{|c|}{3.25} & \multicolumn{2}{|c|}{5.75} & \multicolumn{2}{|c|}{8.25} \\
\hline & & & Pred. & Meas. & Pred. & Meas. & Pred. & Meas. \\
\hline \multirow[t]{8}{*}{1} & 50 & 375.0 & 3.00 & 4.50 & 0.72 & 1.20 & 0.26 & 0.32 \\
\hline & & 750.0 & 9.95 & 10.50 & 3.92 & 3.92 & 0.75 & 0.80 \\
\hline & 75 & 187.5 & 4.38 & 4.16 & 1.98 & 2.08 & 0.43 & 0.48 \\
\hline & & 375.0 & 9.81 & 9.20 & 5.48 & 5.24 & 1.15 & 1.12 \\
\hline & & 750.0 & 20.36 & 20.70 & 10.90 & 10.40 & 2.83 & 2.80 \\
\hline & 100 & 187.5 & 5.05 & 4.95 & 2.97 & 3.20 & 1.03 & 1.12 \\
\hline & & 375.0 & 13.51 & 12.15 & 8.54 & 8.16 & 2.77 & 2.92 \\
\hline & & 750.0 & 26.62 & 25.60 & 14.46 & 14.40 & 5.58 & 5.60 \\
\hline \multirow[t]{9}{*}{2} & 50 & 187.5 & 1.02 & 0.98 & 0.53 & 0.48 & 0.16 & 0.16 \\
\hline & & 375.0 & 1.58 & 1.80 & 0.84 & 0.88 & 0.26 & 0.27 \\
\hline & & 750.0 & 5.52 & 5.55 & 3.79 & 3.44 & 1.63 & 1.44 \\
\hline & 75 & 187.5 & 2.23 & 2.06 & 1.65 & 1.60 & 0.93 & 0.84 \\
\hline & & 375.0 & 3.95 & 4.50 & 2.59 & 2.36 & 1.71 & 1.52 \\
\hline & & 750.0 & 11.33 & 11.25 & 7.36 & 7.04 & 3.38 & 3.36 \\
\hline & 100 & 187.5 & 3.84 & 4.35 & 2.63 & 2.72 & 1.13 & 1.20 \\
\hline & & 375.0 & 9.33 & 9.00 & 5.19 & 5.12 & 2.88 & 2.64 \\
\hline & & 750.0 & 14.86 & 15.00 & 13.23 & 12.00 & 5.67 & 5.60 \\
\hline
\end{tabular}




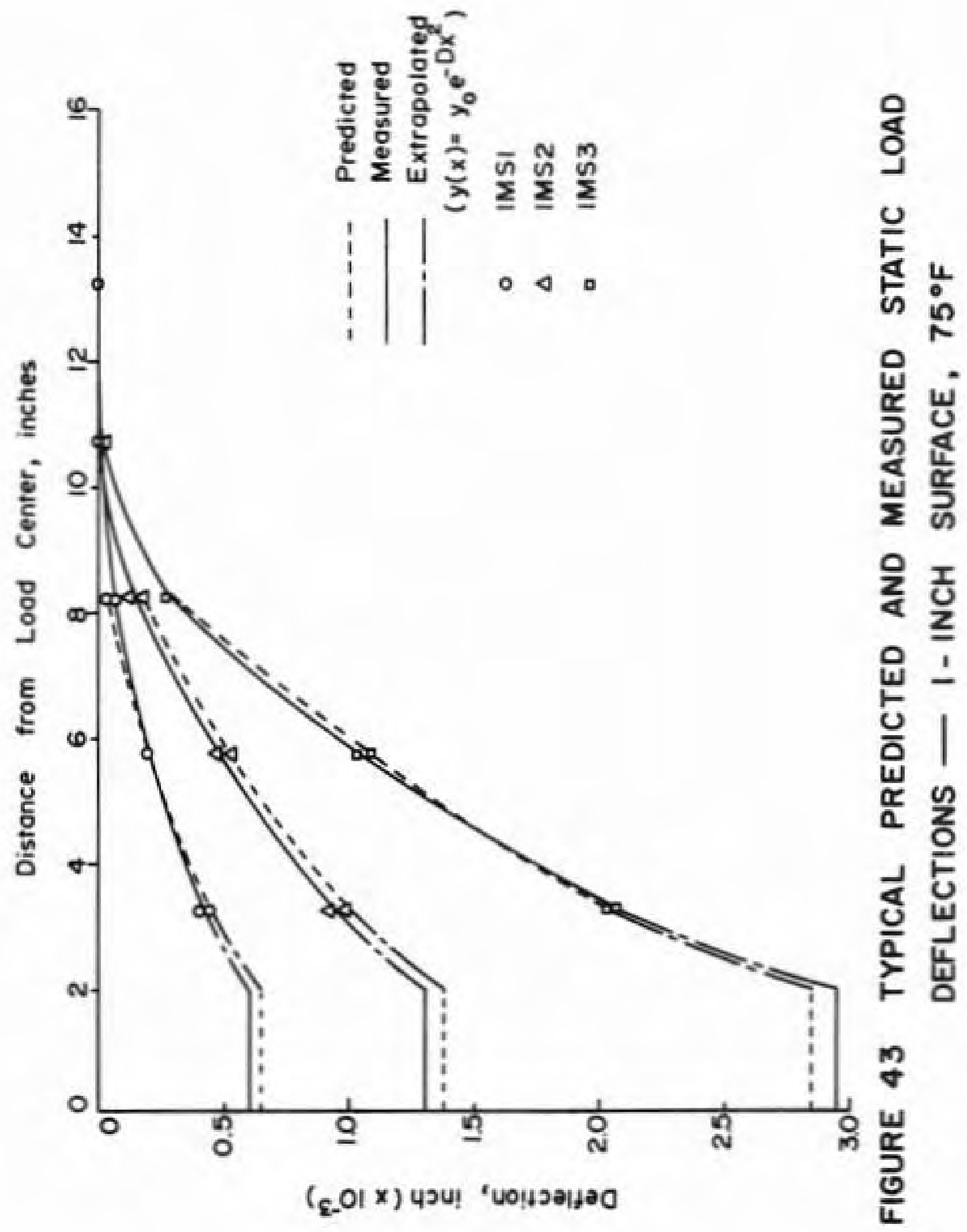




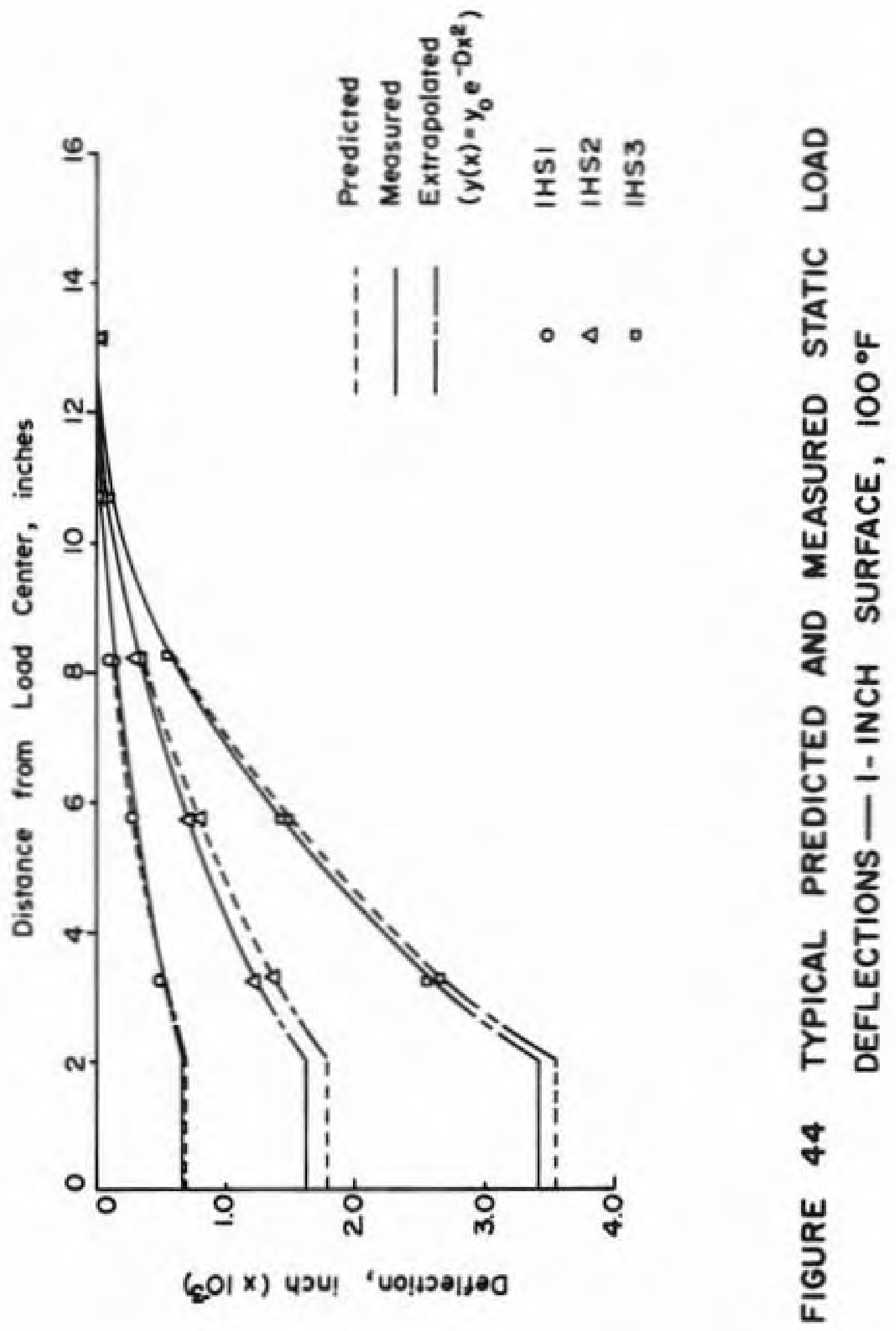




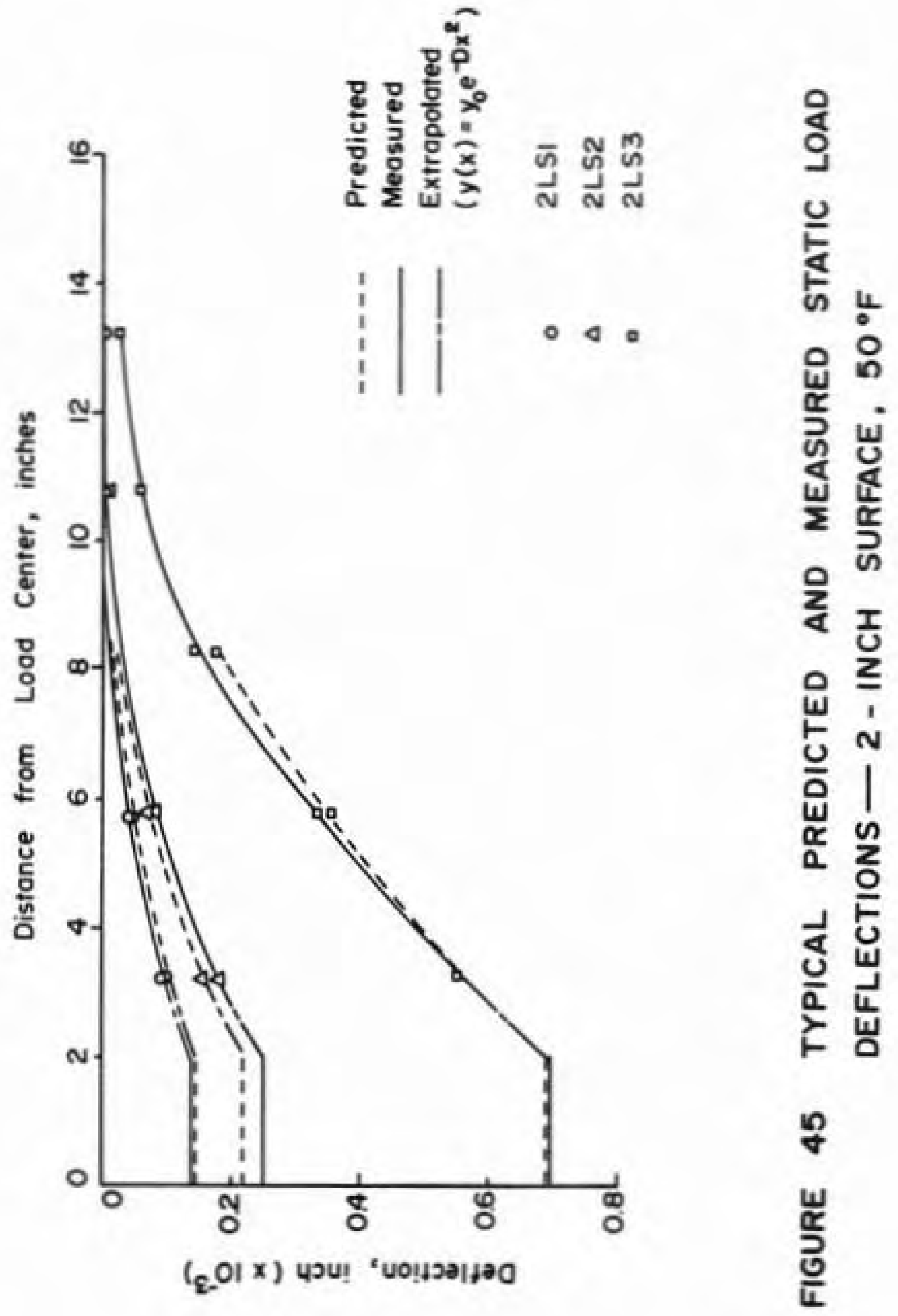




\section{Repeated Load Results}

Haversine load deflections were predicted employing Equations 28 and 30 , respectively, for the total deformation $y_{T}(t)$ and the permanent deformation $y_{P}(t)$. Calculations were effected by the computer program REPLOD of Appendix C. Table 16 shows comparison of predicted and measured values of $y_{T}(t)$. Typical plots are shown in Figures 46,47 and 48 . The agreement is observed to be as good as that in the case of static loads. The results indicate that repeated load deflections, as well as static load deflections, can be predicted using the theory developed in this investigation.

Comparisons of the calculated deflections in Table 15 for the static loads and the corresponding values in Table 16 for the haversine loads show that the magnitudes are essentially the same in both cases. This is not surprising since it is easily verified that the repeated load equation (Equation 28) reduces to the static load equation (Equation $23)$ as the time $t$ gets large. It appears that the time duration of 4 seconds used in haversine load tests is large enough to consider Equation 23 as the limiting case of Equation 28 .

Regarding the measured values of the static load and repeated load deflections presented, respectively, in Tables 15 and 16 , it is noticed that the deflections observed from repeated load tests are always less than those resulting from static load tests. This is due to the difference in 
TABLE 16

PREDICTED AND MEASURED HAVERSINE LOAD DEFLECTIONS

\begin{tabular}{|c|c|c|c|c|c|c|c|c|}
\hline \multirow{4}{*}{$\begin{array}{l}\text { Thick- } \\
\text { ness } \\
\text { in. }\end{array}$} & \multirow{4}{*}{$\begin{array}{l}\text { Temp. } \\
{ }^{\circ} \mathrm{F}\end{array}$} & \multirow{4}{*}{$\begin{array}{l}F_{0} \\
\text { lbs. }\end{array}$} & \multicolumn{6}{|c|}{$\mathrm{y}_{\mathrm{T}}(\mathrm{t})$, inch $\left(\times 10^{-4}\right)$} \\
\hline & & & \multicolumn{6}{|c|}{ Distance from Load Center, inches } \\
\hline & & & \multicolumn{2}{|c|}{3.25} & \multicolumn{2}{|c|}{5.75} & \multicolumn{2}{|c|}{8.25} \\
\hline & & & Pred. & Meas. & Pred. & Meas. & Pred. & Meas. \\
\hline \multirow[t]{8}{*}{1} & 50 & 375.0 & 2.99 & 3.00 & 0.71 & 0.80 & 0.26 & 0.24 \\
\hline & & 750.0 & 9.94 & 9.15 & 3.81 & 3.36 & 0.75 & 0.68 \\
\hline & 75 & 187.5 & 4.37 & 3.98 & 1.98 & 1.92 & 0.43 & 0.40 \\
\hline & & 375.0 & 9.80 & 9.08 & 5.48 & 5.04 & 1.15 & 0.96 \\
\hline & & 750.0 & 20.34 & 19.80 & 10.88 & 10.24 & 2.82 & 2.76 \\
\hline & 100 & 187.5 & 5.04 & 4.32 & 2.97 & 2.52 & 1.03 & 0.96 \\
\hline & & 375.0 & 13.50 & 10.24 & 8.52 & 6.08 & 2.77 & 2.32 \\
\hline & & 750.0 & 26.61 & 24.80 & 14.45 & 13.12 & 5.57 & 4.88 \\
\hline \multirow[t]{9}{*}{2} & 50 & 187.5 & 1.02 & 0.94 & 0.53 & 0.48 & 0.16 & 0.16 \\
\hline & & 375.0 & 1.58 & 1.73 & 0.85 & 0.84 & 0.26 & 0.24 \\
\hline & & 750.0 & 5.52 & 4.95 & 3.79 & 3.40 & 1.63 & 1.40 \\
\hline & 75 & 187.5 & 2.22 & 1.95 & 1.65 & 1.44 & 0.93 & 0.80 \\
\hline & & 375.0 & 3.95 & 3.90 & 2.59 & 2.24 & 1.71 & 1.44 \\
\hline & & 750.0 & 11.32 & 9.15 & 7.35 & 6.40 & 3.38 & 2.88 \\
\hline & 100 & 187.5 & 3.84 & 3.75 & 2.63 & 2.48 & 1.13 & 1.04 \\
\hline & & 375.0 & 9.32 & 8.25 & 5.19 & 5.04 & 2.87 & 2.48 \\
\hline & & 750.0 & 14.84 & 14.63 & 13.22 & 11.04 & 5.66 & 5.04 \\
\hline
\end{tabular}




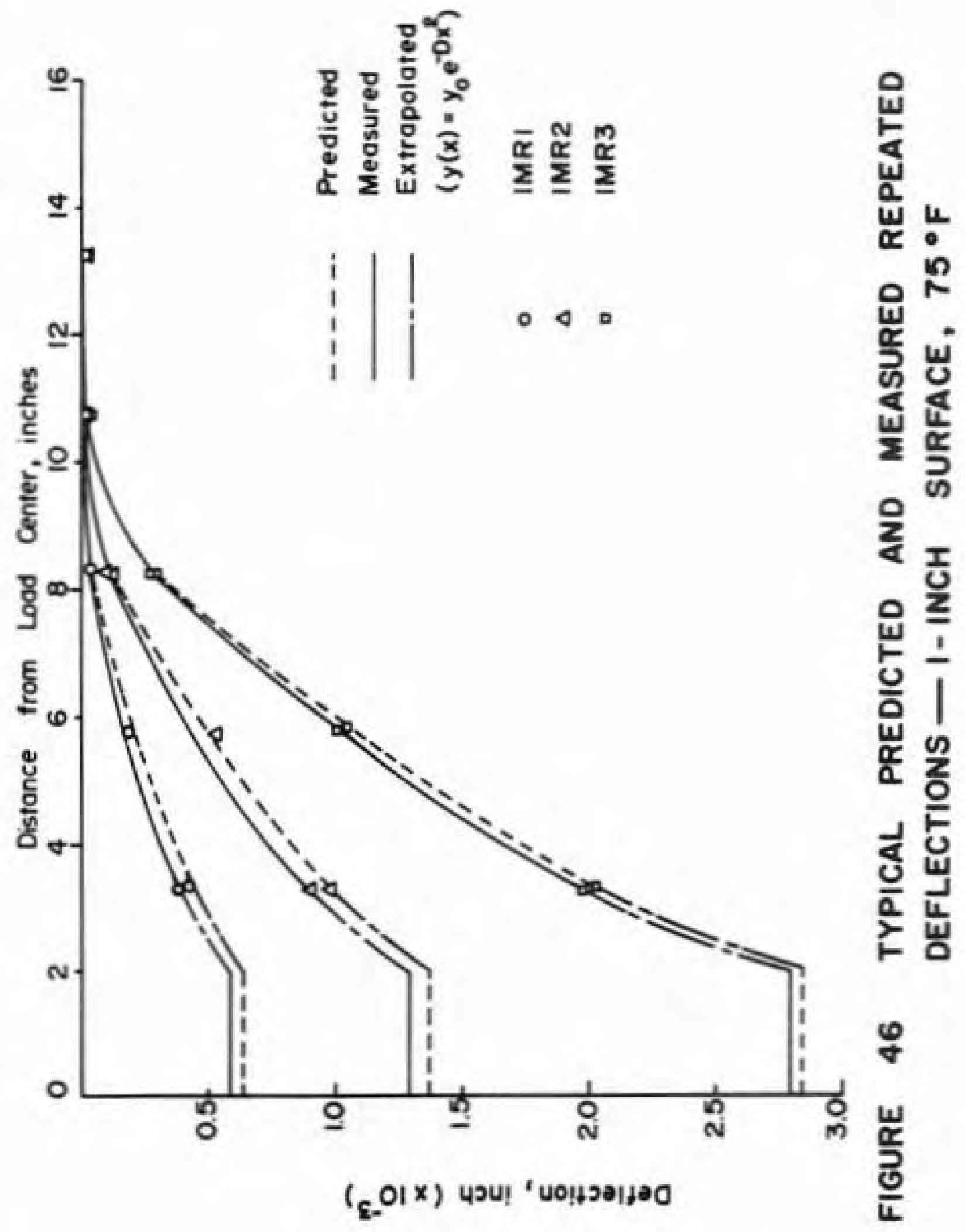




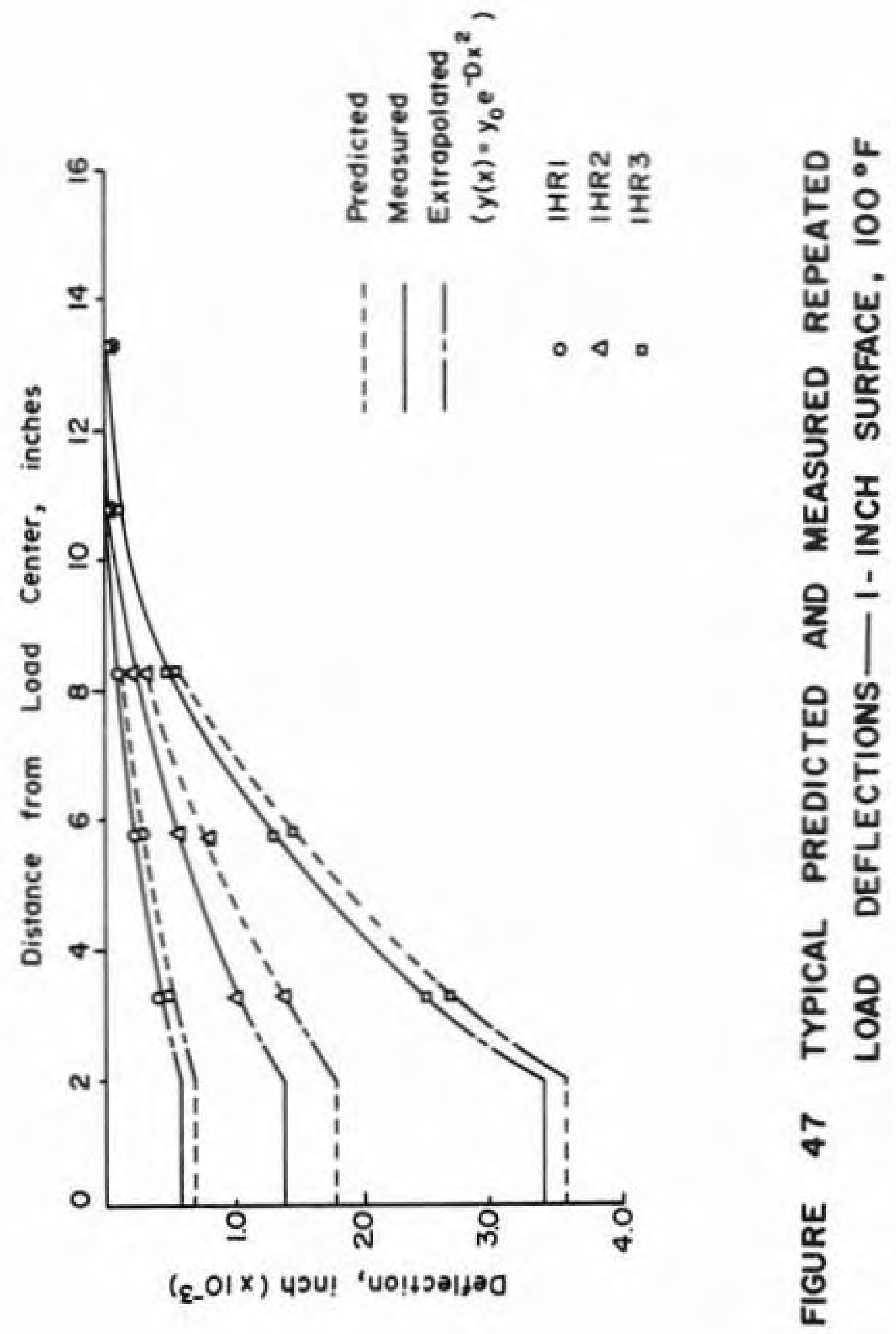




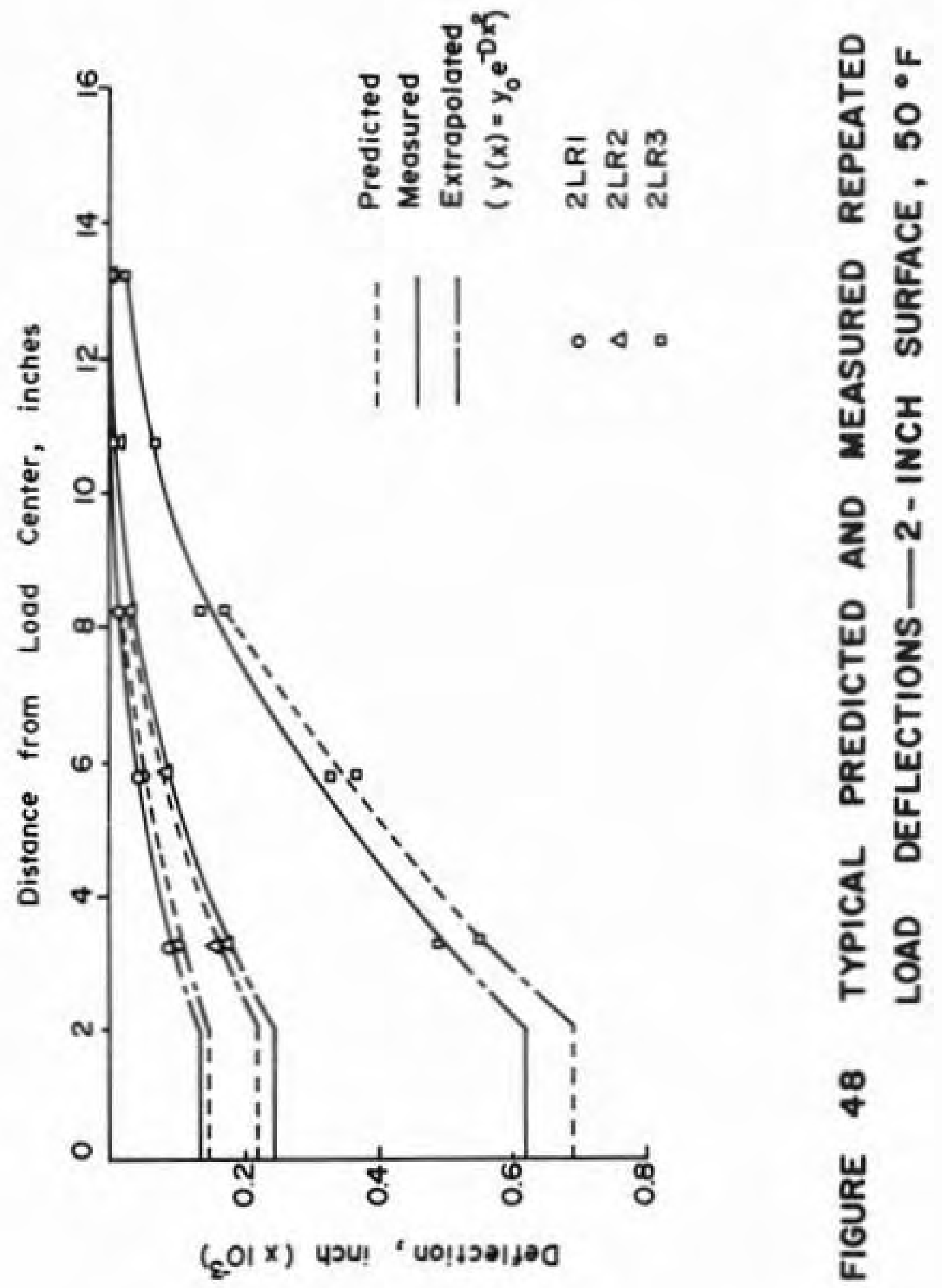


load durations which were, respectively, 4 seconds and a few minutes.

Both the calculated and measured values of the repeated load deflections did not vary with increasing number of load applications. From the theoretical point of view, the terms that would reflect this change are exponential (Equations 28 and 30 ). Because of the rapidly decaying feature of exponential functions, the contribution of these terms to the calculated deflections becomes negligible with increasing number of load applications. Experimentally, observed repeated load deflections at locations other than directly under the load result from the first few cycles and remain constant thereafter. This is indicated in the representative output traces of Figure 24. The observation is also substantiated by the results of Drennon and Kenis [62] obtained from laboratory tests of a full scale, threelayered flexible pavement.

The magnitudes of both calculated and measured values of repeated load permanent deformations $y_{P}(t)$ were too smal1 (in the order of $10^{-5}$ inches or less) for any meaningful interpretations. Theoretically, it is evident from Equation 30 that $y_{p}(t)$ becomes zero in the limit as $t$ increases. From the practical point of view, field observations of flexible pavement behavior indicate that rutting, which is mainly a measure of permanent or non-recoverable deformations, occurs directly under the wheel loads. 


\section{Corner Loading Test Results}

A question arose whether the confinement of the model pavements in a box would have any effect on the center loading test results. Advanced indications of what might be expected were three-fold:

1. Previous laboratory studies dealing with pavements found edge effects to be negligible $[58,61]$.

2. Coating the interior sides of the box with spar varnish diluted with linseed oil would prevent adhesion of the layer materials to the box sides and thus would place no restriction on the vertical pavement response.

3. Deflections measured by LVDT no. 5 at 3 inches from the edge during center loading tests were small indicating that the response at the pavement edges would be small enough to minimize any concern about the effects of confinement.

Nonetheless, to gain more confidence in the over-al1 results, a series of corner loading tests was conducted on the model pavement with a two-inch surface, and at the most severe test conditions regarding edge effects. The two dynamic loads, namely impulse and cyclic, were employed at the 59.72 stress leve1. The test temperature was $50^{\circ} \mathrm{F}$. These tests also had as another objective to see whether the response would vary much at different locations but equidistant from the center of the load. Thus, any non-uniformity in the preparation of the model pavements would be detected. 
The test results of the corner loadings are compared in Table 17 with those of the center loadings. It appears from this table that there is reasonable agreement between the values measured at the inner sides of the plate during corner loading and the corresponding values from center loading. The corner loading results indicate that the magnitudes near the edge are slightly larger than the corresponding values recorded at the inner sides of the plate. This is probably due to the cantilever action that might have influenced the responses near the pavement edges. From the discussion of this section, it can be safely concluded that the edge effects were negligible and that the manner in which the model pavements were prepared is satisfactory. 
TABLE 17

EFFECTS OF CONFINEMENT

\begin{tabular}{|c|c|c|c|c|c|}
\hline & \multicolumn{5}{|c|}{$\begin{array}{r}\text { Surface Course Thickness: } 2 \text { inches } \\
\text { Test Temperature: } 50^{\circ} \mathrm{F} \\
\text { Magnitude of Load: } 750 \mathrm{lbs} .\end{array}$} \\
\hline \multirow[b]{4}{*}{ inches } & \multirow{4}{*}{ Location* } & \multicolumn{4}{|c|}{ Measured Deflections, inch $\left(\times 10^{-4}\right)$} \\
\hline & & \multicolumn{4}{|c|}{ Mode of Loading } \\
\hline & & \multicolumn{2}{|c|}{ Impulse } & \multicolumn{2}{|c|}{ Haversine } \\
\hline & & $\begin{array}{l}\text { Center } \\
\text { Loading }\end{array}$ & $\begin{array}{l}\text { Corner } \\
\text { Loading }\end{array}$ & $\begin{array}{l}\text { Center } \\
\text { Loading }\end{array}$ & $\begin{array}{l}\text { Corner } \\
\text { Loading }\end{array}$ \\
\hline 3.25 & Edge Side & 4.88 & 4.73 & 4.95 & 5.03 \\
\hline \multirow[t]{2}{*}{5.75} & Inner Side & 3.36 & 3.28 & 3.40 & 3.44 \\
\hline & Edge Side & $\cdots$ & 3.36 & $\cdots$ & 3.52 \\
\hline \multirow[t]{2}{*}{8.25} & Inner Side & 1.36 & 1.28 & 1.40 & 1.44 \\
\hline & Edge Side & $\cdots$ & 1.44 & $\cdots$ & 1.52 \\
\hline
\end{tabular}

* For corner loading tests. See Figure 18. 


\section{CONCLUSIONS}

In the present investigation three-layer flexible pavement models utilizing one-inch and two-inch surface course thicknesses were tested. Impulse, static and repeated loads, of intensities $14.93,29.86$ and $59.72 \mathrm{psi}$, were applied at the center of the pavements. A few test series were also conducted at the corner. Test temperatures were $50^{\circ}, 75^{\circ}$ and $100^{\circ} \mathrm{F}$. Based on the results and within the scope of this study, the conclusions are enumerated here. It should be recognized that these conclusions pertain to the materials and testing procedures used in this study. Justifiable extrapolation of the results should be made only upon further testing.

1. Transfer function theory is capable of predicting static or repeated load deflections of flexible pavements. The favorable agreement between predicted and measured values of the deflections in this study validates the hypothesis that the parameters in the response function are material descriptors which are independent of the type of load input.

2. The time-dependent behavior of a flexible pavement can be represented by a response function $G(t)$ which is a function of time $t$. It is possible to obtain this function 
from a single impulse test on the pavement. The response function is independent of the magnitude of the impulse load justifying the assumption of linearity.

3. The response function of a flexible highway pavement is of the form

$$
G(t)=\alpha e^{-B t} \sin \gamma t
$$

where $\alpha, B$ and $\gamma$ are descriptive parameters in the response function.

4. Parameters in the response function are believed to be pavement properties that provide for better understanding of its behavior than those currently used.

5. Temperature, surface course thickness and spatial location have their respective influences on the response function. Increases in temperature increase the value of the $\alpha$ parameter in the response function, while increasing surface course thickness or the distance from the load center decreases the value of $\alpha$. The $\beta$ and $\gamma$ parameters do not seem to be affected appreciably by the above factors.

6. The profile of peak deflections of a flexible highway pavement can be described by the equation

$$
y(x)=y_{0} e^{-D x^{2}}
$$

where $y(x)$ is the deflection at a distance $x$ from the load center, $y_{0}$ is the central deflection and $D$ is a constant reflecting the attenuation of the deflection profile with $x$.

7. The central deflection $y_{0}$ increases with increases in temperature, and decreases with increasing surface course 
thickness. Increases in temperature $\left(50^{\circ} \mathrm{F}-100^{\circ} \mathrm{F}\right)$ or surface course thickness ( 1 inch and 2 inches) decrease the value of the parameter D.

8. Instrumentation and experimental procedures conducted were satisfactory for the test conditions of this investigation. The edge effects due to the confinement of the model pavements in the box are negligible with regard to the results of this study. 
SUGGESTIONS FOR FURTHER RESEARCH

The results of this project have been based on laboratory testing of flexible model pavements. It is realized that this is a first attempt in applying transfer function theory to highway pavements and more work needs to be done. The following research proposals are recommended as extensions of this investigation:

1. In this study, the response functions were approximated by the mathematical model

$$
G(t)=\alpha e^{-\beta t} \sin \gamma t
$$

Mode 1

The following models could be used:

$$
\begin{array}{ll}
G(t)=\alpha e^{-\beta t} \sin \gamma t-\delta \sin \varepsilon t & \text { Model } \\
G(t)=\alpha e^{-\beta t} \sin \gamma t+\delta \cos \varepsilon t & \text { Model }
\end{array}
$$

where $G(t)$ is the response function, $t$ is time and $\alpha, B, \gamma$, $\delta$ and $\varepsilon$ are parameters.

Preliminary analysis of some of the data indicated that using Models 2 and 3 improved the squared correlation coefficient $\left(R^{2}\right)$, as shown in Table 18. The theory of this investigation can be extended after replacing Mode1 1 by either Model 2 or 3. 
TABLE 18

COMPARISON OF $\mathrm{R}^{2}$ FOR DIFFERENT MODELS

\begin{tabular}{|c|c|c|c|c|}
\hline \multirow{2}{*}{ Series } & \multirow{2}{*}{$\begin{array}{c}x \\
\text { inches }\end{array}$} & \multicolumn{3}{|c|}{$\mathrm{R}^{2}$, \& } \\
\hline & & Mode1 (1) & Mode1 (2) & Model (3) \\
\hline \multirow[t]{3}{*}{$1 \mathrm{HI} 1$} & 3.25 & 84.62 & 86.98 & 87.73 \\
\hline & 5.75 & 88.75 & 91.38 & 91.85 \\
\hline & 8.25 & 88.57 & 91.14 & 92.39 \\
\hline \multirow[t]{3}{*}{$1 H 12$} & 3.25 & 83.23 & 90.26 & 86.89 \\
\hline & 5.75 & 83.04 & 89.52 & 90.52 \\
\hline & 8.25 & 78.24 & 87.10 & 86.94 \\
\hline \multirow[t]{3}{*}{$1 \mathrm{HI} 3$} & 3.25 & 84.30 & 88.38 & 88.74 \\
\hline & 5.75 & 81.78 & 88.11 & 87.53 \\
\hline & 8.25 & 84.92 & 91.89 & 91.81 \\
\hline \multirow[t]{3}{*}{$2 \mathrm{HI} 1$} & 3.25 & 83.11 & 85.24 & 89.42 \\
\hline & 5.75 & 87.90 & 92.25 & 91.48 \\
\hline & 8.25 & 84.81 & 91.40 & 88.70 \\
\hline \multirow[t]{3}{*}{$2 \mathrm{HI} 2$} & 3.25 & 86.90 & 88.14 & 90.22 \\
\hline & 5.75 & 89.93 & 95.07 & 93.36 \\
\hline & 8.25 & 92.34 & 93.75 & 96.77 \\
\hline \multirow[t]{3}{*}{$2 \mathrm{HI} 3$} & 3.25 & 80.87 & 83.23 & 89.71 \\
\hline & 5.75 & 89.15 & 90.03 & 93.85 \\
\hline & 8.25 & 93.19 & 94.78 & 96.38 \\
\hline
\end{tabular}


2. The results of this investigation indicate feasibility of conducting field tests on highway pavements. The signatures from a truck travelling over a bump can be used to derive the response functions. Application of transfer function theory to evaluate airport pavements has just been completed $[64]$.

The test program should cover a variety of construction types based on a large statistical sample to permit quantitative evaluation of the effects of the test factors involved. In the present study, the effects of variables were evaluated qualitatively.

3. The mathematical function obtained in this study to describe pavement deflection profiles might be correlated with failure in flexible pavements. Available data or deflections measured from planned field tests may be used for this purpose. By relating the slope of the deflected profile to the nature and extent of pavement failure, a rational method of evaluation could emerge.

4. The pavements in this investigation were tested in their entirety and, as such, isolation of the material properties for each layer was not possible. A research program that would allow determination of the component properties would include testing a single subgrade layer and successively building up to the testing of a complete pavement. 
Limited experimental work with a 3 -inch diameter plate in this study and the results of other investigators [70] indicated that the loaded area may have an effect on pavement properties. Variation of this factor may be incorporated in the laboratory testing program.

5. In this investigation, the measured output parameter was deflection, based on the premise that surface deflections are indicative of a flexible pavement's ability to withstand stresses produced within the pavement by imposed loads [71, 72]. However, this places no restriction on measuring other parameters, such as stress or strain. Inventory tests conducted in this study using strain gages showed that instruments with better resolution would be needed to record strain magnitudes of the order of 20 microns.

6. In the present study, pavement response was analyzed without resort to elastic or viscoelastic theory. However, individuals interested in extending the application of such theory can use the experimental technique of this investigation. By impulse testing material specimens, more reliable properties can be determined and used in conjunction with these theories.

7. The parameters determined in this investigation may be correlated and compared with those obtained by other researchers. 
BIBLIOGRAPHY 


\section{BIBLIOGRAPHY}

1. Hudson, W. R., Finn, F. N., McCullough, B. F., Nair, K. and Vallerga, B. A., "Systems Approach to Pavement Design," Final Report, National Cooperative Highway Research Program, Project $\underline{1-10}$, Highway Research Board, 1968 .

2. Moavenzadeh, F., and Elliott, J. F., "Moving Load on Viscoelastic Layered Systems - Phase 11," Research Report R69-64, Massachusetts Institute of Technology, September, 1969.

3. The AASHO Road Test, Pavement Research Report No. $\underline{5}$, Special Report 61E, Highway Research Board, 1962.

4. McLeod, N. W., "Some Basic Problems in Flexible Pavement Studies," Proceedings, Highway Research Board, Vol. 32 , pp. 90-118, 1953 .

5. Barksdale, R. D., "Elastic and Viscoelastic Analysis of Layered Pavement Systems," Ph.D. Thesis, Purdue University, June, 1966.

6. Yoder, E. J., Principles of Pavement Design, John Wiley, New York, 1959.

7. Boussinewq, J. V., Application des potentiels, GanthierVillars, Paris, 1885 .

8. Burmister, D. M., "The Theory of Stresses and Displacements in Layered Systems and Applications to the Design of Airport Runways," Proceedings, Highway Research Board, Vo1. 23, pp. 1) $26-148,1943$.

9. Burmister, D. M., "The General Theory of Stresses and Displacements in Layered Systems," Journal of Applied Physics, Vol. 16, pp. 89-94, 126-18 $\overline{7}, 296-3 \overline{02}, 1945$.

10. Fox, L., "Computation of Traffic Stresses in a Simple Road Structure," Proceedings, Second International Conference on Soil Mechanics and Foundation Engineering, Rotterdam, Vo1. 2, pp. 236-246, 1948. 
11. Acum, W. E. A., and Fox, L., "Computation of Load Stresses in a Three-Layer Elastic System," Geotechnique, Vo1. 2, No, 4, pp. 293-300, 1951.

12. Mehta, M. R., and Velestsos, A., "Stresses and Displacements in Layered Systems," Structural Research Series, No. 178 , Civil Engineering Studies, University of I11inois, 1959 .

13. Jones, A., "Tables of Stresses in Three-Layer Elastic System," Highway Research Bulletin No. 342, pp. 176214,1962 .

14. Avramesco, A., "Dynamic Phenomena in Pavements Considered as Elastic Layered Structures," Proceedings, Second International Conference on the Structural Design of Asphalt Pavements, University of Michigan, Ann Arbor, pp, 221-224, 1967.

15. Busching, H. W., Goetz, W. H., and Harr, M. E., "StressDeformation Behavior of Anisotropic Bituminous Mixtures," Proceedings, Association of Asphalt Paving Technologists, Vo1. 36, pp. 632-672, 1967 .

16. Terzaghi, K., "The Static Rigidity of Plastic Clays," Journa1 of Rheology, Vo1. 2, No. 3, Ju1y, 1931.

17. Mack, C., "Rheology of Bituminous Mixtures Relative to the Properties of Asphalts," Proceedings, Association of Asphalt Paving Technologists, Vo1. 13, pp. 194-255, 1942 .

18. Schiffman, R. L., "The Use of Viscoelastic Stress-Strain Laws in Soil Testing," A. S. $\underline{\text { T.M. }}$. STP №. 254, pp. 131155,1959 .

19. Lee, E. H., "Viscoelastic Stress Analysis," Structural Mechanics, Proceedings of the First Symposium on Naval Structural Mechanics, Pergamon Press, New York, pp. $456-482,1960$.

20. Lee, E. H., and Rogers, T. G., "Solution of Viscoelastic Analysis Problems Using Measured Creep or Relaxation Functions," Journal of Applied Mechanics, Vol. 30, No. 1, pp. 127-133, March, I963.

21. Secor, K. E., and Monismith, C. L., "Viscoelastic Properties of Asphalt Concrete," Proceedings, Highway Research Board, Vo1. 41, pp. 299-320, 1962 . 
22. Papazian, H. S., "The Response of Linear Viscoelastic Materials in the Frequency Domain with Emphasis on Asphalt Concrete," Proceedings, International Conference on the Structural Design of Asphalt Pavements, University of Michigan, Ann Arbor, pp. 454-463, 1962.

23. Lee, E. H., "Stress Analysis in Viscoelastic Bodies," Quarterly of Applied Mathematics, pp. 183-190, July, 1955 .

24. Biot, M. A., "Dynamics of Viscoelastic Anisotropic Media," Proceedings, Fourth Midwestern Conference on Solid Mechanics, pp. 94-108, September, 1955.

25. Perloff, W. H., and Moavenzadeh, F., "Deflection of Viscoelastic Medium Due to a Moving Load," Proceedings, Second International Conference on the Structural Design of Aspha1t Pavements, University of Michigan, Ann Arbor, pp. 269-276, 1967.

26. Pister, K. S., and Monismith, C. L., "Analysis of Viscoelastic Flexible Pavements," Highway Research Bulletin No. 269, Highway Research Board, pp.1-15, 1960 .

27. Pister, K. S., and Westmann, R. A., "Analys is of Viscoelastic Pavements Subjected to Moving Loads," Proceedings, International Conference on the Structural Design of Asphalt Pavements, University of Michigan, Ann Arbor, pp. 522-529, 1962.

28. Pister, K. S., and Williams, M. L., "Bending of Plates on a Viscoelastic Foundation," Journal of the Engineering Mechanics Division, Proceedings of the A.S.C.E., Vo1. 86, No. EM 5, pp. 31-44, October, 1960.

29. Pister, K. S., "Viscoelastic Plate on a Viscoelastic Foundation," Journal of the Engineering Mechanics Division, Proceedings of the A.S.C.E., Vo1. 87, No. EM 1, Pp. 43-54, February, 1961.

30. Hoskin, B. C., and Lee, E. H., "Flexible Surfaces on Viscoelastic Subgrades," Journal of the Engineering Mechanics Division, Proceedings of the A.S.C.E., Vo1. 85, No. EM 4, pp. 11-30, October, 1959.

31. Huang, Y. H., "Stresses and Displacements in Viscoelastic Layered Systems under Circular Loaded Areas," Proceedings, Second International Conference on the Structural Design of Asphalt Pavements, University of Michigan, Ann Arbor, pp. 225-244, 1967. 
32. Ashton, J. E., and Moavenzadeh, F., "The Analysis of Stresses and Displacements in a Three-Layered Viscoelastic System," Proceedings, Second International Conference on the Structural Design of Aspha1t Pavements, University of Michigan, Ann Arbor, pp. 209-219, 1967.

33. Barksdale, R. D., and Leonards, G. A., "Predicting Performance of Bituminous Surfaced Pavements," Proceedings, Second International Conference on the Structural Design of Asphalt Pavements, University of Michigan, Ann Arbor, pp. 321-340, 1967.

34. Ku, A. B., "Stress-Strain Law for Viscoelastic Flexible Pavement under Temperature Variations," Proceedings, Second International Conference on the Structural Design of Asphalt Pavements, University of Michigan, Ann Arbor, pp. 255-257, 1967.

35. Pagen, C. A., "Rheological Response of Bituminous Concrete," Highway Research Record No. 67, Highway Research Board, pp. 1-26, 1965 .

36. Pagen, C. A., and Ku, A. B., "Effect of Asphalt Viscosity on Rheological Properties of Asphalt Concrete," Highway Research Record No. 104, Highway Research Board, pp. $124-140,1965$.

37. Moavenzadeh, F., "Damage and Distress in Highway Pavements," Structural Design of Asphalt Concrete Pavement Systems, Special Report 126 , Highway Research Board, pp. 114-139, 1971.

38. McClintock, F. A., and Argon, A. S., Mechanical Behavior of Materials, Addison-Wesley, Reading, Massachusetts, p. 253, 1966.

39. Ishihara, K., and Kimura, T., "The Theory of Viscoelastic Two-layer Systems and Conception of Its Application to the Pavement Design," Proceedings, Second International Conference on the Structurai Design of Asphalt Pavements, University of Michigan, Ann Arbor, pp. $245-254,1967$.

40. Frendentha1, A. M., and Lorsch, H. G., "The Infinite Elastic Beam on a Linear Viscoelastic Foundation," Journal of the Engineering Mechanics Division, Proceedings of the A.S.C.E., Vo1. 83, No. EM 1, pp. 1158:1$1158: 22$, January, 1957 . 
41. Monismith, C. L., and Secor, K. E., "Viscoelastic Behavior of Asphalt Concrete Pavements," Proceedings, International Conference on the Structural Design of Asphalt Pavements, University of Michigan, Ann Arbor, pp. $476-498,1962$.

42. Shapery, R. A., "Approximate Methods of Transform Inversion for Viscoelastic Stress Analysis," Proceedings, Fourth U. S. National Congress of Applied Mechanics, A.S.M.E., Vo1. 2, pp. 1075-1085, 1962.

43. Non-Linear Weighted Regression, Computer Science Center, Purdue University.

44. Lattés, R., Lions, J. L., and Bonitzer, J., "Use of Galerkin's Method for the Study of Static and Dynamic Behavior of Road Structures," Proceedings, International Conference on the Structural Design of Asphalt Pavements, University of Michigan, Ann Arbor, pp. 530-536, 1962.

45. Heukelom, W., "Analysis of Dynamic Deflections of Soils and Pavements," Geotechnique, Vo1. XI, No. 3, pp. 224243 , September, 1961.

46. Harr, M. E., "Influence of Vehicle Speed on Pavement Deflection," Proceedings, Highway Research Board, Vol. 41 , pp. 77-82, 1962 .

47. Szendrei, M. E., and Freeme, C. R., "The Computation of Road Deflections under Impulsive Loads from the Results of Vibration Measurements," Proceedings, Second International Conference on the Structural Design of Asphalt Pavements, University of Michigan, Ann Arbor, pp. 141-149, 1967 .

48. Szendrei, M. E., and Freeme, C. R., "Road Responses to Vibration Tests," Journal of the Soil Mechanics and Foundations Division, Proceeding of the A.S.C.E., Vo1. 96, No. SM 6, pp. 2099-2124, November, 1970.

49. Isada, N. M., "Detecting Variations in Load-Carrying Capacity of Flexible Pavements," National Cooperative Highway Research Program Report No. 21, Highway Research Board, 1966 .

50. Isada, N. M., "Impulsive Load Stiffness of Flexible Pavements," Journal of the Soil Mechanics and Foundations Division, Proceedings of the A.S.C.E., Vo1. 96, No. SM 2, pp. 639-648, March, 1970. 
51. Eggleston, T. M., and Mathews, C. W., "Application of Several Methods for Determining Transfer Functions and Frequency Response of Aircraft from Flight Data," U. S. NACA-TR-Report No. $\underline{1204}$, pp. 1-24, 1954 .

52. Crafton, P. A., Shock and Vibration in Linear Systems, Harper \& Brothers, New York, 1961.

53. Goldberg, J. H., Automatic Controls: Principles of Systems Dynamics, A11yn and Bacon, Inc., Boston, 1964 .

54. Puchalka, T., and Wozniak, A., Elements and Circuits for Automatic Control, Boston Technical Publishers, Tnc., Cambridge, Massachusetts, 1968.

55. Langi11, A. A., Jr., Automatic Control Systems Engineering, Volume 1 , Prentice-Hall, Inc., Englewood Cliffs, N. J., 1965 .

56. Swami, S. A., "The Response of Bituminous Mixtures to Dynamic and Static Loads Using Transfer Functions," Ph.D. Thesis, submitted to Purdue University, January, $\overline{19} 6 \overline{9}$.

57. Swami, S. A., Goetz, W. H., and Harr, M. E., "Time and Load Independent Properties of Bituminous Mixtures," Highway Research Record No. 313, Highway Research Board, pp. 63-78, 1970 .

58. Subbaraju, Bh., "Model Study of Stresses in Asphalt Pavements," Proceedings, International Conference on the Structural Design of Asphalt Pavements, University of Michigan, Ann Arbor, pp. 324-331, 1962.

59. Agarwal, S. L., and Hudson, W. R., "Experimental Vertification of Discrete-Element Solutions for Pavement S1abs," Highway Research Record No. 329, Highway Research Board, pp. 1-19, 1970 .

60. Vaswani, N. K., "Optimum Structura1 Strength of Materials in Flexible Pavements," Highway Research Record №. 329 , Highway Research Board, pp. 77-97, $197 \overline{0}$.

61. Waterhouse, A., "Stresses in Layered Systems under Static and Dynamic Loading," Proceedings, Second International Conference on the Structural Design of Asphalt Pavements, University of Michigan, Ann Arbor, pp. 291-308, 1967 . 
62. Drennon, C. B., and Kenis, W. J., Sr., "Response of a Flexible Pavement to Repetitive and Static Loads," Highway Research Record No. 337, Highway Research Board, pp. $40-54,1970$.

63. Brown, S. F., and Pe11, P. S., "An Experimental Investigation of the Stresses, Strains, and Deflections in a Layered Pavement Structure Subjected to Dynamic Loads," Proceedings, International Conference on the Structural Design of Asphalt Pavements, University of Michigan, Ann Arbor, pp. 487-504, 1967,

64. Boyer, R. E., "Predicting Pavement Performance Using Time-Dependent Transfer Functions," Ph.D. Thesis, submitted to Purdue University, August, $19 \overline{72 .}$

65. Nijboer, L. W., "Testing Flexible Pavements under Normal Traffic Loadings by Means of Measuring Some Physica1 Quantities Related to Design Theories," Proceedings, Second International Conference on the Structural Design of Asphalt Pavements, University of Michigan, Ann Arbor, pp. 689-705, 1967.

66. Odemark, N., "Investigations as to the Elastic Properties of Soils and Design of Pavements According to the Theory of Elasticity," Stabens Vaginstitut, Stockholm, 1949 .

67. Beaton, J. L., Zube, E., and Forsyth, R., "Field Application of the Resilience Design Procedure for Flexible Pavement," Proceedings, Second International Conference on the Structural Design of Asphalt Pavements, University of Michigan, Ann Arbor, pp. 355-366, 1967.

68. Kung, Kuang-Yuan, "A New Method in Correlation Study of Pavement Deflection and Cracking," Proceedings, Second International Conference on the Structural Design of Asphalt Pavements, University of Michigan, Ann Arbor, pp. $1037-1046,1967$.

69. The Aspha1t Institute, Mix Design Methods for Asphalt Concrete (MS-2), 1969 .

70. Skok, E. L., Jr., and Finn, F. N., "Theoretical Concepts Applied to Asphalt Concrete Pavement Design," Proceedings, International Conference on the Structura1 Design of Asphalt Pavements, University of Michigan, Ann Arbor, pp. $412-440,1962$. 
71. Ha11, J. W., "Nondestructive Testing of Flexible Pavements - A Literature Review," Technical Report No. AFWL-TR-68-147, Air Force Systems Command, Kirt1and Air Force Base, New Mexico, May, 1970.

72. Yoder, E. J., "Flexible Pavement Deflections - Methods of Analysis and Interpretation," Proceedings, Association of Asphalt Paving Technologists, VoI. 31, pp. 260288,1962 . 
APPENDICES 
APPENDIX A

REDUCED IMPULSE DATA 


\section{Program}

PROGRAM MAIN (INPUT, OUTPUT, PUNCH, TAPE5=1NPUT, TAPE6=0UTPUT, 1TAPE 7 = PUNCH, PLOT)

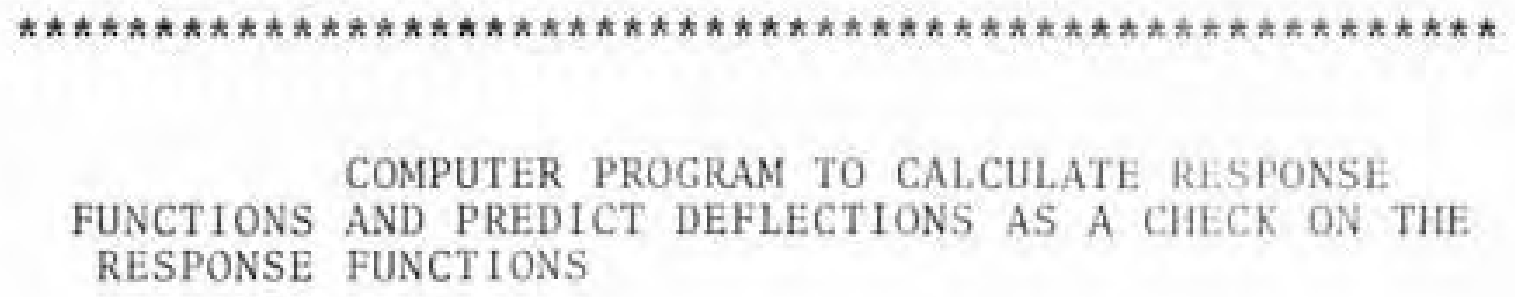


2MFLAG, NDATA , NFLAG , (M( $(1), I=1,6),($ IPS $(1), 1=1,6)$, GXX

GO TO $(29,700)$, IFLAG

29 DO $30 \quad I=1,6$

$30 \operatorname{READ}(5,102)$ (DEFL $(1, K), K=1, N)$

WRITE $(6,200)$

DO $261 \mathrm{~K}=1, \mathrm{~N}$

$261 X(K)=$ FLOAT $(K) * D T-D T$

DO $262 \mathrm{~K}=1, \mathrm{~N}$

262 WRITE $(6,201) \times(K), \operatorname{DEFL}(I, K), I=1,4)$

500 DO $501 \quad \mathrm{I}=1,6$

DO $501 \mathrm{~K}=1, \mathrm{~N}$

$501 \mathrm{GF}(\mathrm{I}, \mathrm{K})=0.0$

IF (IFLAG.EQ.1) $\quad$ GF $(2$, NPHASE $)=$ SPIKE

DO $504 \quad \mathrm{I}=1,5$

IF (M(I).EQ,0)GO TO 504

DO $502 \mathrm{~K}=1, \mathrm{~N}$

$\operatorname{XINP}(K)=\operatorname{DEFL}(1, K)$

$502 \operatorname{XOUT}(K)=\operatorname{DEFL}(I+1, K)$

CALL CONVLI (XINP, XOUT, XG, DT , N , GXX)

Do $503 \mathrm{~K}=1, \mathrm{~N}$

$\mathrm{GT}(\mathrm{I}+1, \mathrm{~K})=\mathrm{XG}(\mathrm{K})$

$503 \mathrm{GF}(\mathrm{I}+1, \mathrm{~K})=\mathrm{XG}(\mathrm{K})$

504 CONTINUE

WRITE $(6,107)$ (NAME $(L), L=1,9)$

WRITE $(6,203)$

1572 DO $505 \mathrm{~K}=1, \mathrm{~N}$

$X(K)=F L O A T(K) * D T-D T$

WRITE $(6,202) \times(K),(G F(I, K), I=2,4)$

505 CONTINUE

C1120 PUNCH

IF (JFLAG.EQ. 0) GO TO 525

DO $530 \mathrm{~K}=1, \mathrm{~N}$

$V_{2}(K)=0.0$

$\mathrm{V} 3(\mathrm{~K})=0.0$

$\mathrm{V} 4(\mathrm{~K})=0.0$

$\mathrm{V} 5(\mathrm{~K})=0.0$

$V 6(K)=0.0$

C

530 CONTINUE

C

C

506 CONTINUE

DO $506 \mathrm{~K}=1, \mathrm{~N}$

$\mathrm{V} 2(\mathrm{~K})=\mathrm{GF}(2, \mathrm{~K})$

$\mathrm{V} 3(\mathrm{~K})=\mathrm{GF}(3, \mathrm{~K})$

$V 4(K)=G F(4, K)$

$\operatorname{Vs}(K)=\mathrm{GF}(5, K)$

$\mathrm{V} 6(\mathrm{~K})=\mathrm{GF}(6, \mathrm{~K})$

CALL SCALES $(10.0, \mathrm{~V} 2, \mathrm{~N}, 1, \mathrm{~V} 3, \mathrm{~N}, 1, \mathrm{~V} 4, \mathrm{~N}, 1, \mathrm{~V} 5, \mathrm{~N}, 1, \mathrm{~V} 6, \mathrm{~N}, 1)$

C

CALL SCALE $(x, 10.0, N, 1)$

C

PLOT AXES AND ANNOTATION.....

C 
CALL AXIS $(0,0,0,0,12 \mathrm{HTTME}$,SECONDS, $-12,10.0,0.0, \mathrm{X}(\mathrm{N}+1)$, $1 \mathrm{X}(\mathrm{N}+2), 0)$

CALL AXIS $(0.0,0.0,17$ HRESPONSE FUNCTION, 17, 10.0,90,0, $1 V 2(\mathrm{~N}+1), \mathrm{V} 2(\mathrm{~N}+2),-1)$

CALL SYMBOL $(3.5,10,0,0.2,18$ HRESPONSE FUNCTIONS, 0.0,18)

CALL. SYMBOL $(8.0,8.20,0.08,1,0.0,-1)$

CALL SYMBOL $(8.1,8.14,0.08,11 \mathrm{H}$-RESPONSE $1,0.0,11)$

CAL.L SYMBOL $(8.0,8.1,0.08,2,0.0,-1)$

CALL SYMBOL $(8.1,8.04,0.08,11 \mathrm{H}-\mathrm{RESPONSE} 2,0,0,11)$

CALL SYMBOL $(8.0,8.0,0.08,3,0.0,-1)$

CALL SYMBOL $(8.1,7.94,0.08,11 \mathrm{H}-\mathrm{RESPONSE} 3,0,0,11)$

CALL. SYMBOL $(8.0,7.9,0.08,4,0.0,-1)$

CALL SYMBOL $(8.1,7.84,0.08,11 \mathrm{H}$-RESPONSE $4,0.0,11)$

CALL. SYMBOL $(8.0,7,8,0.08,5,0.0,-1)$

CALL SYMBOL $(8.1,7,74,0.08,11 \mathrm{H}$-RESPONSE $5,0.0,11)$

CALL SYMBOL $(8.0,7,7,0.08,6,0.0,-1)$

CALL. SYMBOL $(8.1,7.64,0.08,11 \mathrm{H}$-RESPONSE $6,0.0,11)$

C

C

C C

\section{CONTINUE}

DO $517 \quad \mathrm{I}=1,5$

IF(M(I).EQ.0) GO TO 517

DO $509 K=1, N$

$509 z(K)=G F(1, K)$

$\mathrm{Z}(\mathrm{N}+1)=\mathrm{V} 2(\mathrm{~N}+1)$

$Z(N+2)=V 2(N+2)$

517 CONTINUE

CALL PLOT $(18,0,0.0,-3)$

700 IF(MDATA.EQ. 0) GO TO 702

701 READ $(5,102)$ (DEFL $(1, K), K=1, N)$

702 IF(MFLAG.EQ.0) GO TO 704

DO $703 \quad I=2,4$

$703 \operatorname{READ}(5,102)(\mathrm{GT}(1, \mathrm{~K}), \mathrm{K}=1, \mathrm{~N})$

C

704 DO $706 \mathrm{~K}=1, \mathrm{~N}$

$\mathrm{GF}(1, \mathrm{~K})=\mathrm{DEFL}(1, \mathrm{~K})$

$706 \mathrm{X} 1 \mathrm{NP}(\mathrm{K})=\operatorname{DEFL}(1, \mathrm{~K})$

$\mathrm{XINP}(3)=10 .{ }^{*} \mathrm{GXX}$

707 DO $710 \quad I=2,4$

DO $708 \mathrm{~K}=1, \mathrm{~N}$

$708 \mathrm{XG}(\mathrm{K})=\mathrm{GT}(1, \mathrm{~K})$

CALL CONVLE (XINP, XOUT, XG, DT , N)

DO $709 \mathrm{~K}=1, \mathrm{~N}$

$709 \mathrm{GF}(\mathrm{I}, \mathrm{K})=$ XOUT $(\mathrm{K})$

710 CONTINUE 
WRITE $(6,107)$ (NAME $(L), L=1,9)$

WRITE $(6,207)$

DO $711 \mathrm{~K}=1, \mathrm{~N}$

$711 X(K)=$ FLOAT $(K) * D T-D T$

DO $712 \mathrm{~K}=1, \mathrm{~N}$

712 WRITE $(6,201) \times(K),(G F(I, K), I=1,4)$

$1001 \mathrm{~N}=\mathrm{N} 1$

1000 CONTINUE

IF(IPLOT.NE.0) CALL PLOT $(0,0,999)$

C
C
C
C
C
C
C

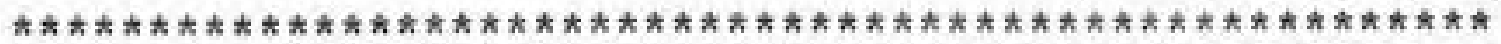

.... FORMAT STATEMENTS....

100 FORMAT $(313, \mathrm{~F} 10.5,411)$

101 FORMAT $(1811,612$, F10.5)

102 FORMAT $(8 \mathrm{~F} 10.5)$

103 FORMAT (I 2)

108 FORMAT (8F10.8)

200 FORMAT (///25X, 'RECORD OF RAW DATA', ///8X, 'TIME' , $2 \mathrm{X}$, 1'LOAD, LBS.' , 3X, 'D E F L E C T I O N S, IN,', //7X,' (SEC) ' $\left.2,4 \mathrm{X},,^{\prime} \mathrm{X}=0^{\prime}, 6 \mathrm{X},{ }^{\prime} \mathrm{X}=3.25^{\prime}, 5 \mathrm{X},{ }^{\prime} \mathrm{X}=5.75^{\prime}, 5 \mathrm{X},{ }^{\prime} \mathrm{X}=8.25^{\prime} / / /\right)$

201 FORMAT $((1 \mathrm{X}, \mathrm{F} 11.2, \mathrm{~F} 8.1,3(\mathrm{~F} 11.6))$

202 FORMAT ( $1 \mathrm{X}, \mathrm{F} 12.3,3(\mathrm{~F} 14.8))$

203 FORMAT $(/ / /, 8 \mathrm{X}$, 'RESPONSE FUNCTIONS FROM IMPLICIT CONVO' 1'LUTION'//8X,'TIME', $7 \mathrm{X}, \mathrm{C}^{\prime} \mathrm{R}$ E S P O N S E F U N C T I ' $2^{\prime} \mathrm{N}^{\mathrm{N}} \mathrm{S}^{\prime} / / 7 \mathrm{X},{ }^{\prime}(\mathrm{SEC})^{\prime}, 7 \mathrm{X},{ }^{\prime} \mathrm{X}=3.25^{\prime}, 8 \mathrm{X},,^{\prime} \mathrm{X}=5.75^{\prime}, 8 \mathrm{X},{ }^{\prime} \mathrm{X}=8.25^{\prime}$ $3 / / /)$

204 FORMAT (1X, F12.6, $12 \mathrm{X}, 5 \mathrm{~F} 12.6)$

206 FORMAT $(1 X, 2 \mathrm{~F} 12.6)$

207 FORMAT $(/ / /, 9 X$, 'DEFLECTIONS FROM RESPONSE FUNCTIONS AN' 1'D LOAD', ///8X, 'TIME', $2 \mathrm{X}$, 'LOAD, LBS. ', 3X, 'D E F L E C ' $2^{\prime} \mathrm{T}$ I O N S, IN. ' $/ / 7 \mathrm{X},{ }^{\prime}(\mathrm{SEC})^{\prime}, 4 \mathrm{X},,^{\prime} \mathrm{X}=0^{\prime}, 6 \mathrm{X},{ }^{\prime} \mathrm{X}=3.25^{\prime}, 5 \mathrm{X}$, $\left.3^{\prime} \mathrm{X}=5.75^{\prime}, 5 \mathrm{X},{ }^{\prime} \mathrm{X}=8.25^{\prime} / / / /\right)$

208 FORMAT $\left(1 \mathrm{H} 1,1 \mathrm{X} / / / / / / / / / / / / / / / / / / / / / / / / / 1 \mathrm{X},{ }^{\prime}\right.$

210 FORMAT (21 (8E10.3/),7E10.3)

C

214 FORMAT (2F10.8)

C

स:

STOP

END

C

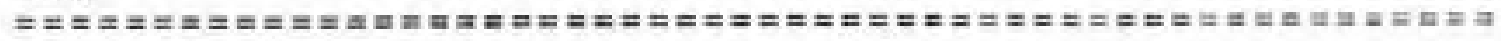

$\mathrm{C}$

C 


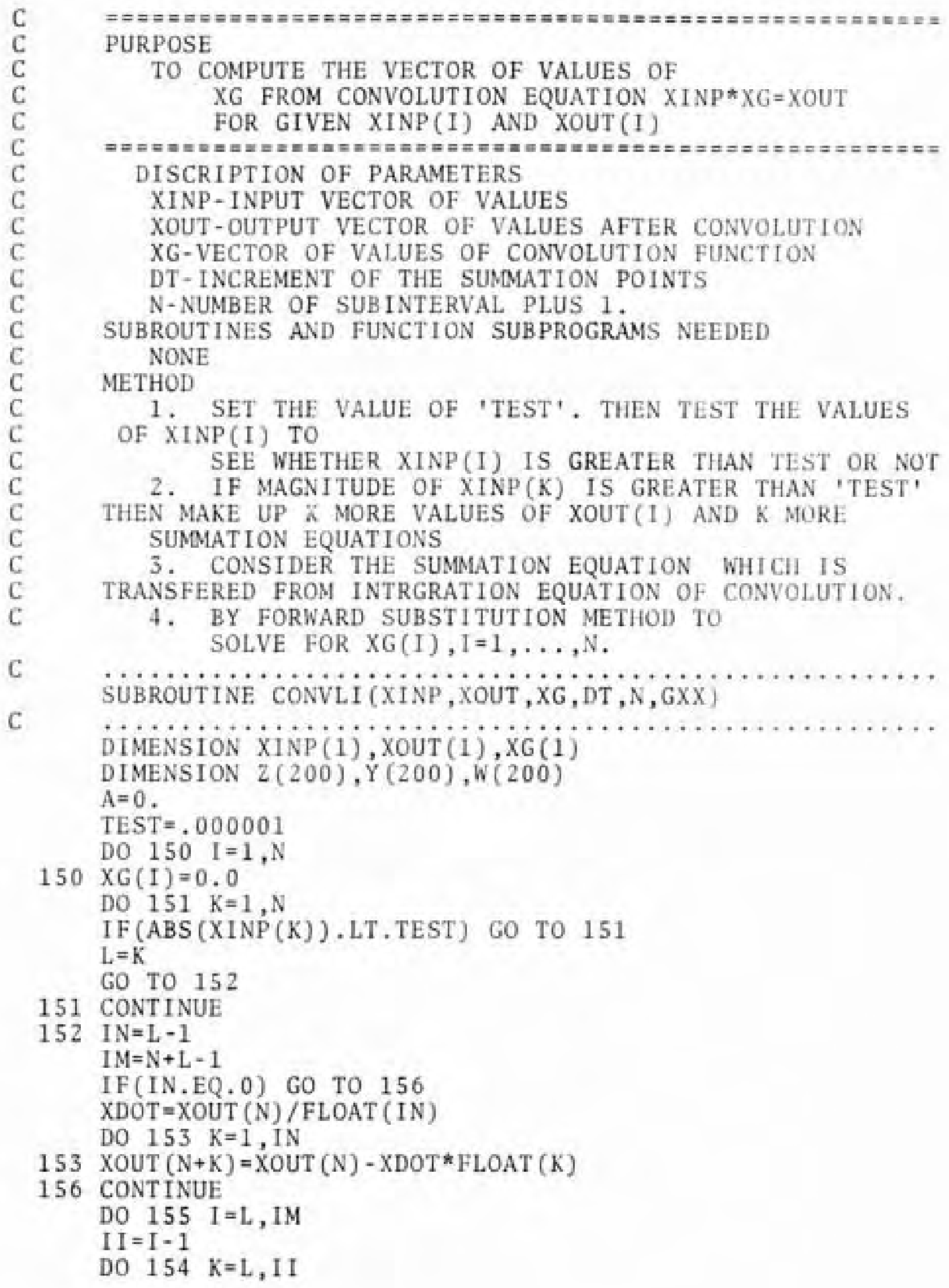




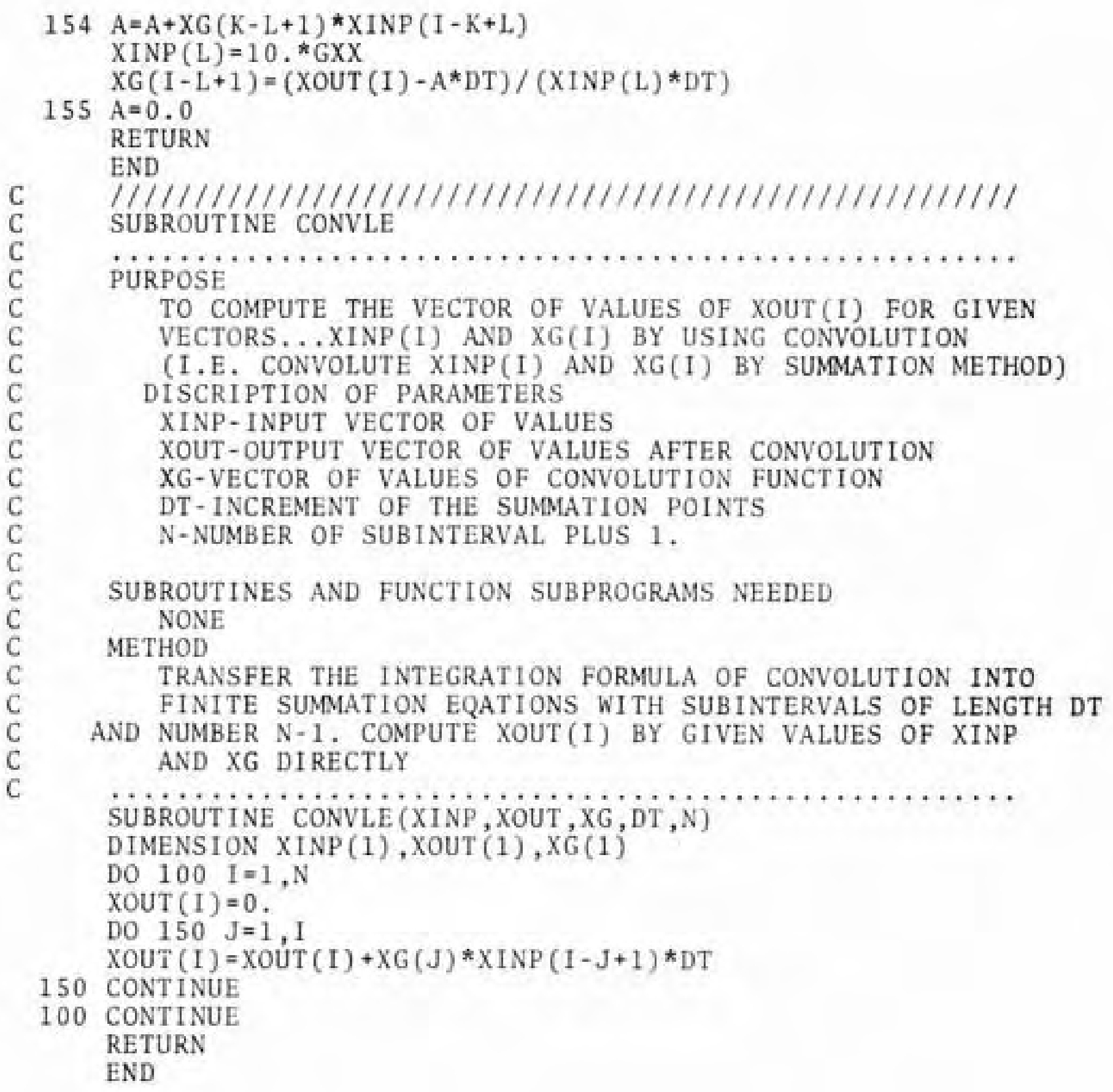




\section{Reduced Data}

The reduction of the impulse test data was implemented using the progran of this Appendix. Each test series consists of three tables. These are: input and outputs (raw data), response functions and predicted deflection functions, in that order. 
11. T?

RECORD OF PAW NATA

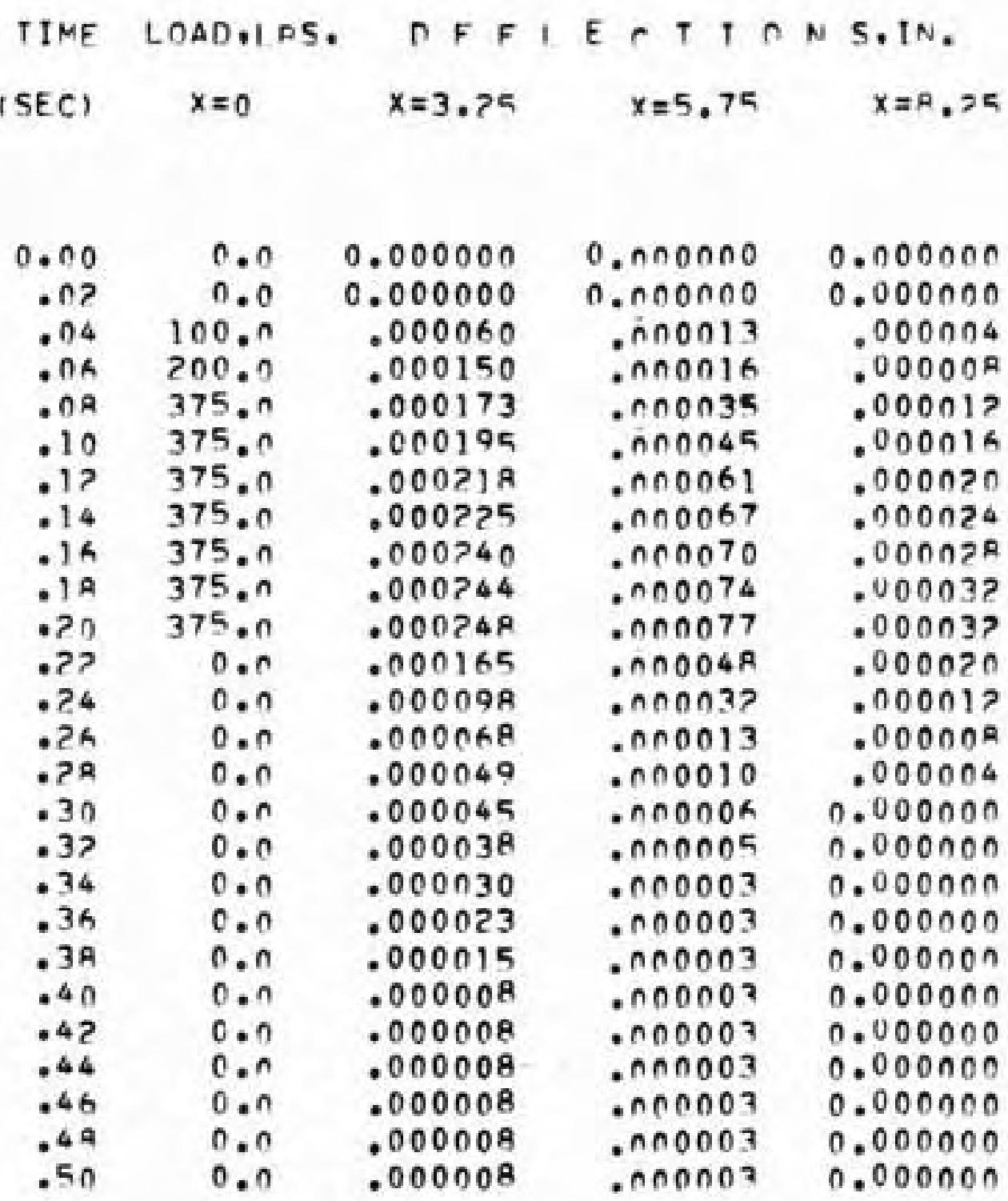


RESPONSE FUNRTIONS FROM TMPLTCIT CONVOLITION

TIMF

(SEC)
R F $\& P \cap$

$x=3.25$

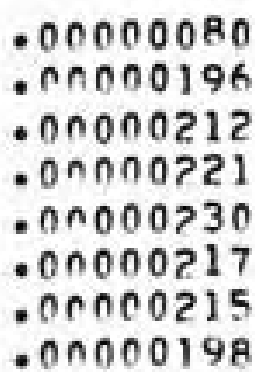

- CNOCO183

- 00000061

- . 00000020

- $\cap 0000041$

-.0ก000041

- . 0ก000019

- 0n000004

.00000008

- On000018

. 00000025

.00000019

.00000015

- On000009

. 00000004

. On000001

- 00000001

-.00000004

$-.00000007$
- conanariz

- nonncozo

- ODnnO044

- nonnCO5

- cornanozo

- nOANAOTz

- nOnOnORg

. OOAnOOAT

- OONODOAL

- nOnOnOzl

-. $000 \cap 0003$

- oOnOnOZZ

-.000nn0zl

- $0000 \cos$

-.000n0010

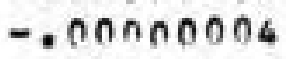

- nO0nO003

- OOONCO10

- nOONDO11

- conno010

.00000006

.00000003

$.000 A n 001$

- . DOAnNOOC

-.000nco0?

.00000004
.00000005

. 00000010

.00000015

.00000019

.00000073

.00000026

$.000000>9$

.00000031

$.00000 n>R$

.00000010

.0000000 ?

. $.000 n 00 n 6$

$-.00000009$

$-.00000011$

- .0000nORa

. .00000004

$-.00000000$

.00000003

.00000004

.00000003

.00000002

$.000000 n 1$

$-.00000000$

$-.00000001$

.00000001

. .00000001 


\section{ILI?}

DEFLECTIONS FRCM RESPONSF FIINCTIONS ANO LOAR

TIME LOAD,IPS. DFFLECT TON S,IN.
(SEC) $x=0 \quad x=3.25 \quad x=5.75 \quad x=8.25$

\begin{tabular}{|c|c|c|c|c|}
\hline $\begin{array}{r}0.00 \\
.02\end{array}$ & $\begin{array}{l}0.0 \\
0.0\end{array}$ & $\begin{array}{l}0.000000 \\
0.000000\end{array}$ & $\begin{array}{l}0.000000 \\
0.000000\end{array}$ & $\begin{array}{l}0.000 \cap 00 \\
0.000000\end{array}$ \\
\hline .04 & 100.0 & .000060 & $.0 n 0013$ & .000004 \\
\hline .06 & 200.0 & .000150 & . OOCOOIA & .000008 \\
\hline .08 & 375.0 & .000173 & $.00 C 035$ & $.000 \cap 12$ \\
\hline .10 & 375.0 & .000195 & $.0 n 0045$ & $.00001 \mathrm{~h}$ \\
\hline .12 & 375.0 & .000218 & .000061 & $.0000>0$ \\
\hline .14 & 375.0 & .000225 & .000067 & .000024 \\
\hline .16 & 375.0 & $.00024 n$ & .000070 & $.00002 A$ \\
\hline .18 & 375.0 & .000244 & .010074 & $.00003 ?$ \\
\hline .20 & $375 . n$ & .000248 & .000077 & .000037 \\
\hline .22 & 0.0 & .000165 &.$\cap \cap 004 R$ & $.0000>0$ \\
\hline .24 & 0.0 & - 00009 A & $\cdot \cap n C 03 ?$ & $.00001 ?$ \\
\hline .26 & 0.0 & .000068 & .000013 & $.00000 A$ \\
\hline .28 & 0.0 & .000049 & .000010 & .000004 \\
\hline$\cdot 30$ & $0 . n$ & .000045 & - ANCOOAR & $=.000000$ \\
\hline .32 & 0.0 & $.00003 A$ & .000005 & $.000 n \cap 0$ \\
\hline .34 & 0.0 & $.00003 n$ & .000003 & 0.000000 \\
\hline .36 & 0.0 & .000073 & $.0 n 0003$ & $-.000 \cap \cap 0$ \\
\hline - 38 & 0.0 & .000015 & .000003 & $=0000000$ \\
\hline .40 & 0.0 & $.00000 \mathrm{~A}$ & .000003 & -.000000 \\
\hline .4? & 0.0 & .000008 & .000003 & $=000000$ \\
\hline .44 & 0.0 & $.00000 R$ & .000003 & .000000 \\
\hline .46 & 0.0 & .000008 & .000003 & 0.000000 \\
\hline .48 & 0.0 & $.00000 R$ & .000003 & $.00000 n$ \\
\hline $.5 n$ & 0.0 & .000008 & .000003 & .000000 \\
\hline
\end{tabular}




\section{ILI 3}

RECORD OF PAW DATA

TIME LOADIRS. DEFLECTIONS,IN. (SEC) $\quad x=0 \quad x=3.25 \quad x=5.75 \quad x=8.25$

\begin{tabular}{|c|c|c|c|c|}
\hline $\begin{array}{r}0.00 \\
.02\end{array}$ & $\begin{array}{l}0.0 \\
0.0\end{array}$ & $\begin{array}{l}0.0000000 \\
0.000000\end{array}$ & $\begin{array}{l}0.000000 \\
0.0 n 0000\end{array}$ & $\begin{array}{l}0.0000000 \\
0.000000\end{array}$ \\
\hline .06 & $\begin{array}{l}400.0 \\
720.0\end{array}$ & $\begin{array}{l}.000075 \\
.000525\end{array}$ & $\begin{array}{l}.00003 ? \\
00010 ?\end{array}$ & $\begin{array}{l}.000010 \\
.00002 ?\end{array}$ \\
\hline .OA & 750.0 & .000675 & .000256 & .000051 \\
\hline .10 & 750.0 & .000705 & .0100296 & 00059 \\
\hline .12 & 750.0 & .000720 & .000300 & $.0000 \times 1$ \\
\hline .14 & 750.0 & .000735 &.$n 00300$ & .000062 \\
\hline -16 & 750.0 & .000750 & .000304 & 000064 \\
\hline .18 & 750.0 & $.00075 R$ & .000304 & 00066 \\
\hline .20 & 750.0 & .000765 & .000304 & 00067 \\
\hline .22 & 0.0 & .000450 & .000152 & $.00004 \mathrm{~A}$ \\
\hline .24 & 0.0 & .000165 & .000032 & .000019 \\
\hline .26 & 0.0 & .000105 & .0100024 & .000010 \\
\hline .28 & 0.0 & .000090 & .000016 & .000006 \\
\hline .30 & 0.0 & .000075 & .000012 & 00003 \\
\hline - 32 & 0.0 & .000060 & .000008 & .000002 \\
\hline .34 & 0.0 & .000045 &.$\cap \cap 000 A$ & .000002 \\
\hline - 36 & 0.0 & .000030 & $.00000 A$ & .000002 \\
\hline . 38 & 0.0 & .000023 &.$\triangle O O O O A$ & $.00000 ?$ \\
\hline .40 & 0.0 & .000015 & .000008 & $.00000 ?$ \\
\hline .42 & 0.0 & .000015 & $.00000 A$ & $.00000 ?$ \\
\hline .46 & 0.0 & .000015 & .000008 & $.00000 ?$ \\
\hline .46 & 0.0 & .000015 & $.00000 A$ & $.00000 ?$ \\
\hline .48 & 0.0 & .000015 & .000008 & .000002 \\
\hline .50 & $0 . n$ & .000015 & .000008 & $.00000 ?$ \\
\hline
\end{tabular}


RESPONSE FUNTTIONS FROM IMPITCIT CONVOLITION

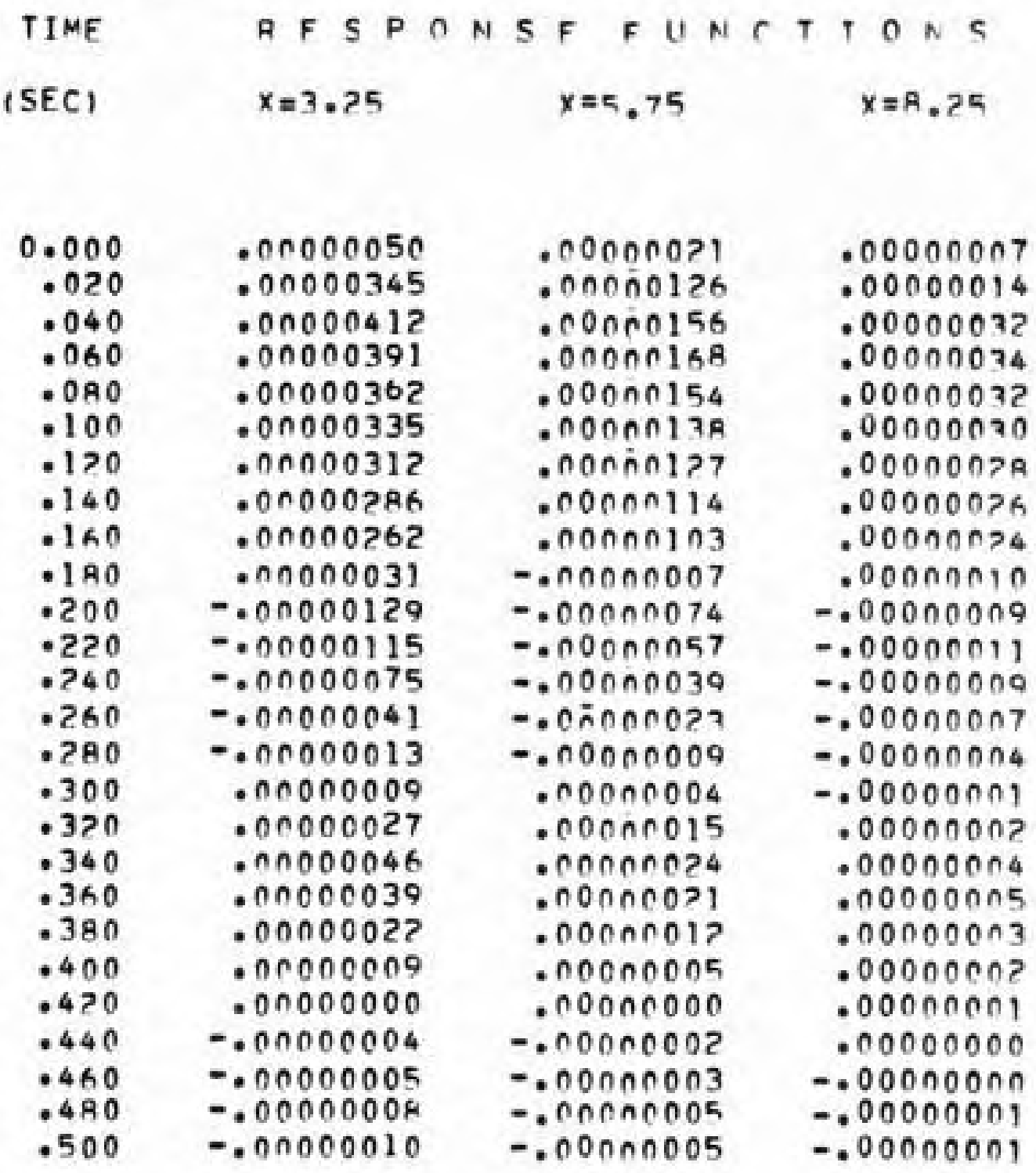




\section{LI?}

DEFLECTIONS FROM RESPONSF FIINCTIONG ANO LOAN

TIME LOAD.LAS. DFFLECT TON S.IN.
(SEC) $\quad x=0 \quad x=3.25 \quad x=5.75 \quad x=8.75$

\begin{tabular}{|c|c|c|c|c|}
\hline $\begin{array}{r}0.00 \\
.02\end{array}$ & $\begin{array}{l}0.0 \\
0.0\end{array}$ & $\begin{array}{l}0.0000000 \\
0.000000\end{array}$ & $\begin{array}{l}0.000000 \\
0.000000\end{array}$ & $\begin{array}{l}0.000000 \\
0.000000\end{array}$ \\
\hline .04 & 400.0 & $\begin{array}{r}.000075 \\
.000555\end{array}$ & - 000032 & $\begin{array}{l}.000010 \\
.00002 ?\end{array}$ \\
\hline .08 & $750 . n$ & .000675 & - nnOPas & .000051 \\
\hline .10 & 750.0 & .000705 & - 010296 & .000059 \\
\hline .12 & 750.0 & .000720 & .000300 & .000061 \\
\hline .14 & 750.0 & .000735 & .000300 & .000067 \\
\hline .16 & 750.0 & .000750 & .000304 & .000064 \\
\hline .18 & 750.0 & .000758 & .000304 & $.0000 E 6$ \\
\hline & 750.0 & .000765 & .000304 & .000067 \\
\hline .22 & 0.0 & .000450 & $.0 \cap 0152$ & $.00004 \mathrm{~A}$ \\
\hline .24 & 0.0 & .000165 & $.00003 ?$ & .000019 \\
\hline & & .000105 & . 000024 & .000010 \\
\hline $\begin{array}{r}.28 \\
.30\end{array}$ & $\begin{array}{l}0.0 \\
0.0\end{array}$ & .000090 & $\begin{array}{l}-n 00016 \\
000001 ?\end{array}$ & $\begin{array}{l}.00000 R \\
.000003\end{array}$ \\
\hline .32 & 0.0 & .000060 & .000008 & .000002 \\
\hline .34 & 0.0 & .000045 & .000008 & $.00000 ?$ \\
\hline 26 & 0.0 & .000030 & .000008 & .000002 \\
\hline . 38 & 0.0 & .000023 & $.00000 R$ & .000007 \\
\hline .40 & 0.0 & .000015 & .000008 & .000007 \\
\hline .42 & 0.0 & .000015 & .000008 & .000002 \\
\hline .44 & 0.0 & .000015 & $.00000 B$ & $.00000 ?$ \\
\hline .46 & 0.0 & .000015 & $.0 \cap 0008$ & .000002 \\
\hline & $0 . n$ & .000015 & $=\cap 0000 A$ & $.00000 ?$ \\
\hline .50 & 0.0 & .000015 &.$\cap \cap 000 R$ & $.00000 ?$ \\
\hline
\end{tabular}


$1 \mathrm{MII}$

RECORD OF RAW DATA

TIME LOAD.LAS. DEFLECTION S,IN.

(SEC) $\quad x=0 \quad x=3.25 \quad x=5.75 \quad x=8,25$

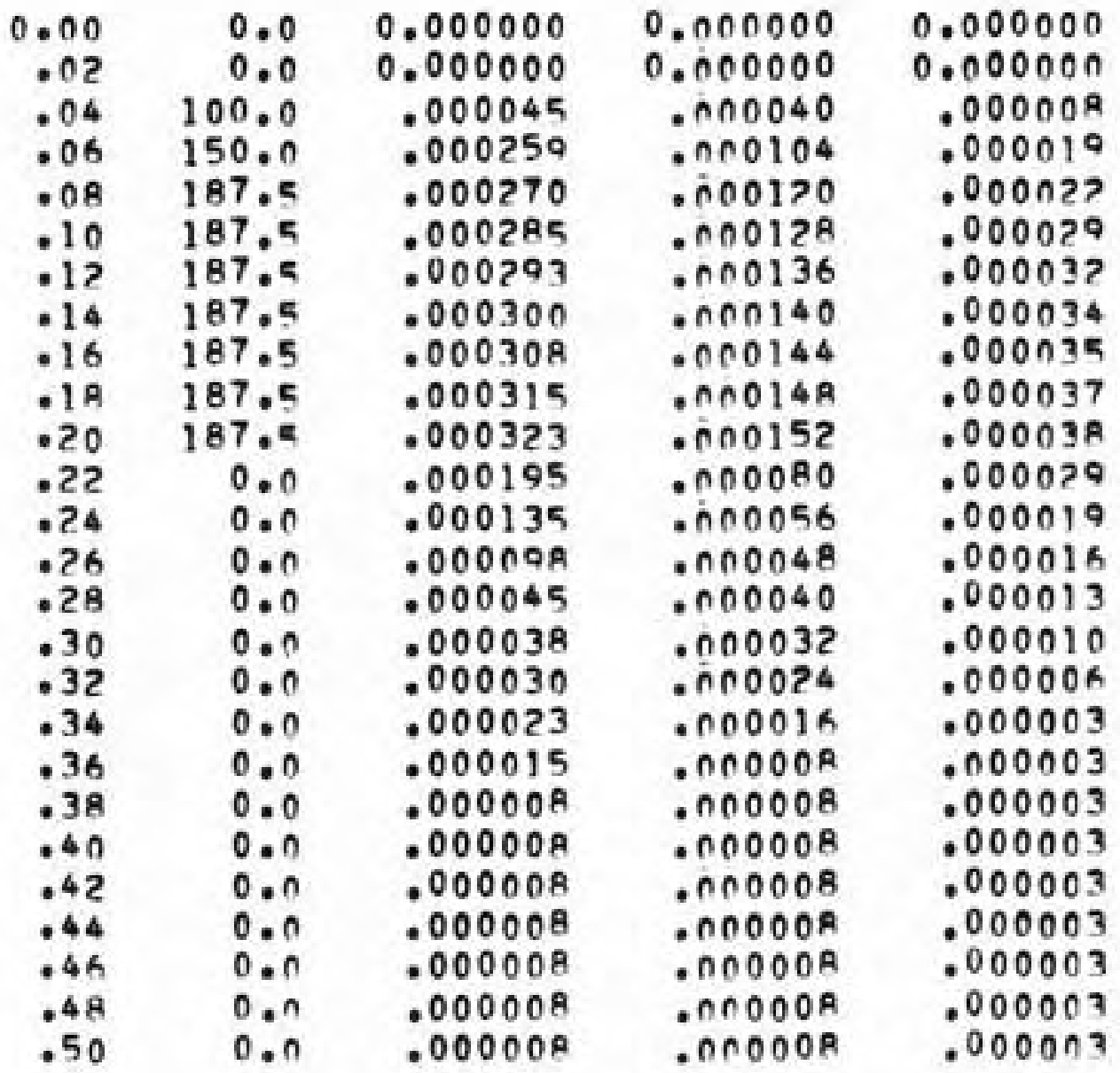


IMII

RESPONSE FUNCTIONS FROM IMPI TCIT CONVOLIITION

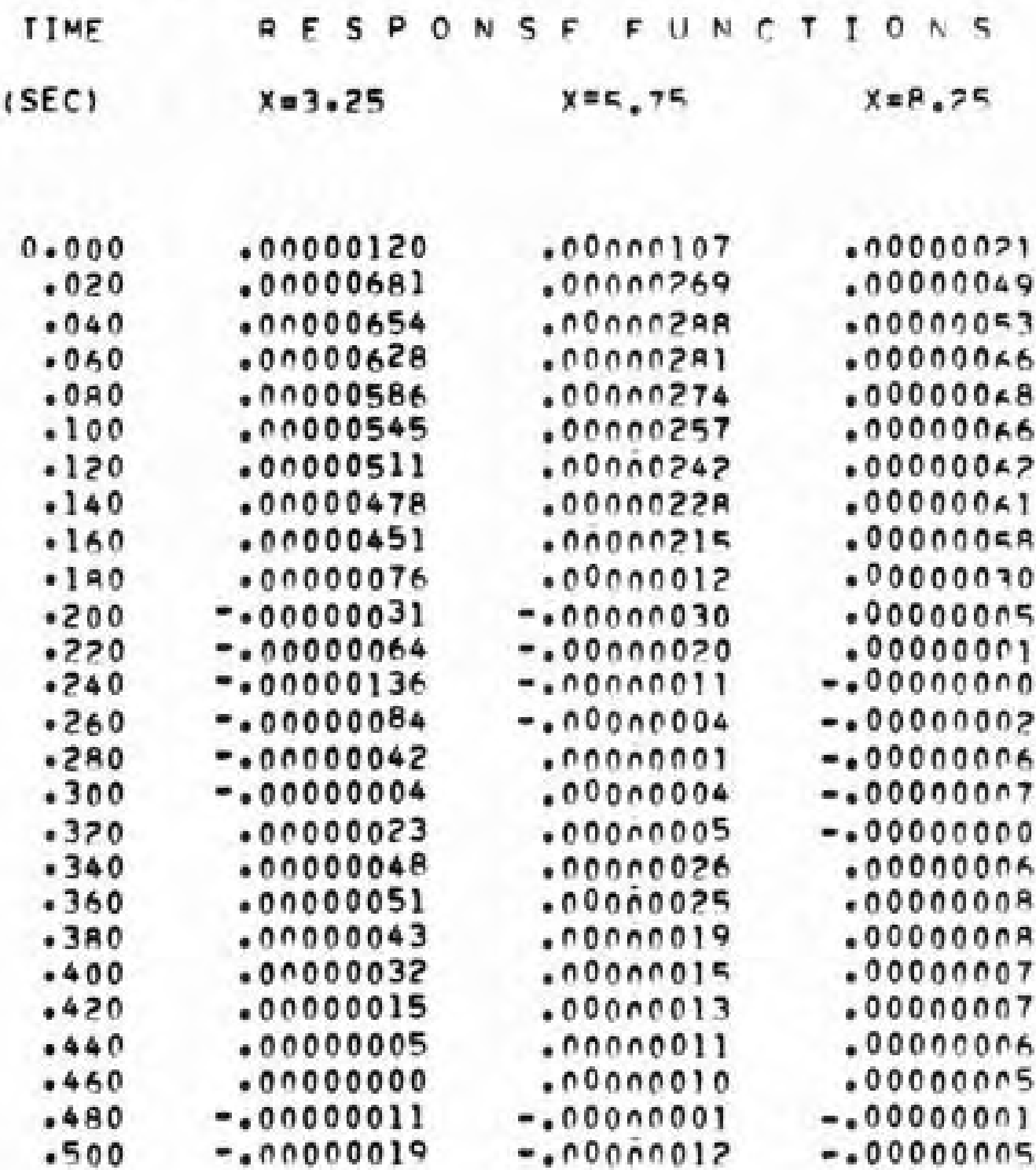


DEFLECTIONS FROM RESPONSF FIINCTIONS AND IOAN

\begin{tabular}{|c|c|c|c|c|}
\hline $\begin{array}{l}\text { TIME } \\
\text { (SEC) }\end{array}$ & $\begin{array}{c}\text { LOAD, LRS } \\
x=0\end{array}$ & $\begin{array}{c}\text { DEF } \\
x=3.25\end{array}$ & $\begin{array}{c}E \subset T I 0 \\
x=5.75\end{array}$ & $\begin{array}{l}\text { N S,IN. } \\
x=R, 25\end{array}$ \\
\hline $\begin{array}{r}0.00 \\
.02\end{array}$ & $\begin{array}{l}0.0 \\
0.0\end{array}$ & $\begin{array}{l}0.000000 \\
0.000000\end{array}$ & $\begin{array}{l}0 . \cap \cap 0000 \\
0 . \cap 000000\end{array}$ & $\begin{array}{l}0.000000 \\
0.000000\end{array}$ \\
\hline $\begin{array}{l}.04 \\
.06\end{array}$ & $\begin{array}{l}100.0 \\
150.0\end{array}$ & $\begin{array}{l}.000045 \\
.000250\end{array}$ & $\begin{array}{l}\text { OnNOOSO } \\
\text { OnnOInA }\end{array}$ & $\begin{array}{l}.00000 R \\
.000019\end{array}$ \\
\hline $\begin{array}{l}.08 \\
.10\end{array}$ & $\begin{array}{l}187.0 \\
187.5\end{array}$ & $\begin{array}{l}.000270 \\
.000285\end{array}$ & $\begin{array}{l}\text {-nnoizo } \\
\text {. nnolze }\end{array}$ & $\begin{array}{l}.00002 ? \\
.000020\end{array}$ \\
\hline $\begin{array}{l}.12 \\
.14 \\
116 \\
119 \\
.20\end{array}$ & $\begin{array}{l}187.5 \\
187.5 \\
187.5 \\
187.5 \\
187.5\end{array}$ & $\begin{array}{l}.000293 \\
.000300 \\
.000308 \\
.000315 \\
.000323\end{array}$ & 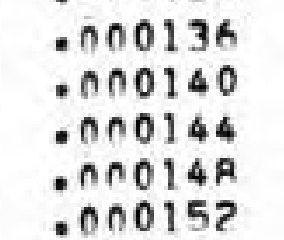 & $\begin{array}{l}.000037 \\
.0000334 \\
.0000035 \\
.000037 \\
.000038\end{array}$ \\
\hline .22 & 0.0 & .000195 & - $\operatorname{COOOORO}$ & .000020 \\
\hline $\begin{array}{l}.24 \\
.26\end{array}$ & $\begin{array}{l}0.0 \\
0.0\end{array}$ & $\begin{array}{l}.000135 \\
.000098\end{array}$ & $\begin{array}{l}\text {. } n \cap 005 K \\
\text {. } n \cap 0048\end{array}$ & $\begin{array}{l}.000019 \\
.000016\end{array}$ \\
\hline & $\begin{array}{l}0.0 \\
0.0\end{array}$ & $\begin{array}{l}.000045 \\
.000038\end{array}$ & $\begin{array}{l}n 00040 \\
\text { - } 100032\end{array}$ & $\begin{array}{l}.000013 \\
.000010\end{array}$ \\
\hline & $\begin{array}{l}0.0 \\
0.0\end{array}$ & & $\begin{array}{l}\text {. } \cap n 0024 \\
. \cap n O 016\end{array}$ & $\begin{array}{l}.00000 \% \\
.000003\end{array}$ \\
\hline .36 & 0.0 & .000015 & .010008 & .000003 \\
\hline $\begin{array}{l}.38 \\
.40\end{array}$ & $\begin{array}{l}0.0 \\
0.0\end{array}$ & $\begin{array}{l}.000008 \\
.000008\end{array}$ & $\begin{array}{l}\text { ONOOOOAB } \\
. \cap 00008\end{array}$ & $\begin{array}{l}.000003 \\
.000003\end{array}$ \\
\hline $\begin{array}{l}.47 \\
.44\end{array}$ & $\begin{array}{l}0.0 \\
0.0\end{array}$ & $\begin{array}{l}.000008 \\
.000008\end{array}$ & $\begin{array}{l}\text { OCOOOOR } \\
. \triangle \cap O O O B\end{array}$ & $\begin{array}{l}.000003 \\
.000003\end{array}$ \\
\hline $\begin{array}{l}.46 \\
.48\end{array}$ & $\begin{array}{l}0.0 \\
0.0\end{array}$ & $\begin{array}{l}.000008 \\
.000008\end{array}$ & $\begin{array}{l}. O N O D O R \\
. O \cap 000 R\end{array}$ & $\begin{array}{l}.000003 \\
.000003\end{array}$ \\
\hline .50 & 0.0 & .000008 & - ONOOOR & .000003 \\
\hline
\end{tabular}


RECORD OF RAW DATA

\begin{tabular}{|c|c|c|c|c|}
\hline $\begin{array}{l}\text { TIME } \\
\text { (SEC) }\end{array}$ & $\begin{array}{c}\text { LOAD LAS } \\
x=0\end{array}$ & $\begin{array}{c}\text { DEF } \\
X=3.25\end{array}$ & $\begin{array}{l}E \subset T \text { I } \\
x=5.75\end{array}$ & $\begin{array}{l}\text { NoIN. } \\
x=8, ?=\end{array}$ \\
\hline 0.00 & 0.0 & 0.000000 & $0 . n 00000$ & 0.000000 \\
\hline .02 & 0.0 & 0.000000 & $0 . \cap n 0000$ & 0.000000 \\
\hline $\begin{array}{l}.04 \\
.06\end{array}$ & $\begin{array}{l}200 \cdot 0 \\
300.0\end{array}$ & $\begin{array}{l}.000120 \\
.000608\end{array}$ & - n00064 & .000003 \\
\hline . $O A$ & 375.0 & .000638 & . คnO336 & .000073 \\
\hline .10 & 375.0 & .000653 & .000352 & .000077 \\
\hline .12 & 375.0 & $.00066 A$ & .000368 & .000000 \\
\hline $\begin{array}{l}.14 \\
.16\end{array}$ & $\begin{array}{l}375.0 \\
375.0\end{array}$ & $\begin{array}{l}.000690 \\
.000713\end{array}$ & $\begin{array}{l}\text { OnnO376 } \\
\text { On } \cap 0384\end{array}$ & $\begin{array}{l}.000087 \\
.000083\end{array}$ \\
\hline $\begin{array}{l}.18 \\
.20\end{array}$ & $\begin{array}{l}375.0 \\
375.0\end{array}$ & $\begin{array}{l}.000735 \\
.000750\end{array}$ & $\begin{array}{l}-\operatorname{nnO} 0302 \\
.000400\end{array}$ & $\begin{array}{l}.0000 A 5 \\
.0000 A A\end{array}$ \\
\hline .22 & 0.0 & .000413 & - in 0256 & .000058 \\
\hline .24 & 0.0 & .000293 & . 010176 & .00002 \\
\hline .26 & 0.0 & .000128 & .000112 & .000019 \\
\hline .28 & 0.0 & .000098 &.$\triangle 0 O O P O$ & .000013 \\
\hline .30 & 0.0 & .000060 & . $\cap 00056$ & .000010 \\
\hline 32 & 0.0 & .000045 & .000040 & .000006 \\
\hline .34 & $0 . n$ & .000030 & .000024 & .000005 \\
\hline . 36 & 0.0 & .000023 & . $\cap 00016$ & .000003 \\
\hline - $3 R$ & 0.0 & .000015 & .000016 & .000003 \\
\hline .40 & 0.0 & .000015 & . $\cap 00016$ & .000003 \\
\hline .42 & 0.0 & .000015 & .000016 & .000003 \\
\hline .44 & 0.0 & .000015 & - AnOOOIA & $.0000 \mathrm{r}$ \\
\hline .46 & 0.0 & .000015 & .000016 & .00000 \\
\hline $.4 R$ & 0.0 & .000015 & - ก๊ก0016 & 00000 \\
\hline .50 & 0.0 & .000015 &.$\cap 00016$ & .000003 \\
\hline
\end{tabular}


RESPONSE FUNCTIONS FROM IMPLICIT CONVOLITIOA

TIME

(SEC)

0.000

.020

.040

.060

- DRO

.100

.120

.140

.160

190

.200

.220

.240

.260

.280

.300

. 320

.340

- 360

. 380

.400

.420

.440

.450

.480

.500
RESPON S

$x=3.25$

$x=5.75$

$x=8.25$

$.000 n 00 R 5$

. 000nतL?O

.00000406

- noninazar

- nO0nOzá

- OnCNO342

$.000 n 031 a$

. 00000296

$.000 n 0277$

$.000 n 0065$

-.000n0010

$-.00000055$

. .00000055

$-.000 n 0044$

-.00000027

.000000013 .000 ñD007 .00000035

$.000 \cap 0038$ .00000034 - 000no0z5 $.000 n n 016$ - nODnOOIn .00000006

. $.000 \hat{00006}$

$-.00000016$
.00000004 $.00000 n R A$ $.000000 R 9$ $.0000002 K$ .00000 na? $.0000007 a$ .00000070 $.000000<5$ $.000000<0$ .00000017

$-.00000019$

$-.00000073$

-.00000016

. 00000010

$-.00000007$

. .00000000 .00000004 $.000000 n a$ .00000010 .00000007 .00000004 $.000000 \pi 2$ $.000000 n 1$ .00000000

-.0000000 ?

. .00000003 
$1 M 12$

DEFLECTIONS FROM RESPONSF FIINCTIONE ANR LAAN

TIME LOAD,LAS. DEFLECT TON S,IN.

(SEC) $\quad x=0 \quad x=3.25 \quad x=5.75 \quad x=8.25$

\begin{tabular}{|c|c|c|c|c|}
\hline 0.00 & 0.0 & 0.000000 & 0.000000 & 0.000000 \\
\hline $\begin{array}{l}.07 \\
.04\end{array}$ & $\begin{array}{r}0.0 \\
200.0\end{array}$ & $\begin{array}{r}0.000000 \\
.000120\end{array}$ & $\begin{array}{r}0 . \cap 00000 \\
. \cap \cap 00 R 4\end{array}$ & $\begin{array}{r}0.000000 \\
.000003\end{array}$ \\
\hline .06 & 300.0 & $.00060 R$ & .000320 & .000 OA \\
\hline .08 & 375.0 & .000638 &. $\operatorname{nnO} 336$ & .000072 \\
\hline .10 & 375.0 & .000653 &.$\cap 00352$ & .000077 \\
\hline .12 & 375.0 & $.00066 B$ & .000368 & $.000 \cap 80$ \\
\hline .14 & 375.0 & .000690 & . $\triangle 100376$ & .0000 ? \\
\hline .16 & 375.0 & .000713 & . nn 0384 & .000003 \\
\hline . 1A & 375.0 & .000735 & . 000392 & 00085 \\
\hline -20 & 375.0 & .000750 & - $\cap 00400$ & $.00000 A$ \\
\hline .22 & 0.0 & .000413 & .000256 & .000059 \\
\hline .24 & 0.0 & .000293 & - $\cap 100176$ & .000024 \\
\hline .26 & 0.0 & $.00012 R$ & . $\cap 0011$ ? & $.00001 \mathrm{~A}$ \\
\hline .28 & 0.0 & .000098 & . $\cap 0 O O R O$ & .000013 \\
\hline$\cdot 30$ & 0.0 & .000060 & $.00005 A$ & .000010 \\
\hline .32 & 0.0 & .000045 & .000040 & .000006 \\
\hline .34 & 0.0 & .000030 & .010024 & .000005 \\
\hline .36 & 0.0 & .000023 & .0100016 & .000003 \\
\hline . 38 & 0.0 & .000015 &.$A n 0016$ & .000003 \\
\hline .40 & 0.0 & .000015 & .000016 & .000003 \\
\hline .42 & 0.0 & .000015 &.$\cap n 0016$ & .000003 \\
\hline .44 & & .000015 & .000016 & .000003 \\
\hline .46 & 0.0 & .000015 & $.0 \cap 0016$ & .000003 \\
\hline .48 & 0.0 & .000015 & - AnO01A & .000003 \\
\hline .50 & 0.0 & .000015 & - AnO016 & .000003 \\
\hline
\end{tabular}




\section{$1 M I 3$}

RECORD OF RAW DATA

\begin{tabular}{|c|c|c|c|c|}
\hline $\begin{array}{l}\text { TIME } \\
\text { (SEC) }\end{array}$ & $\begin{array}{l}\text { LOAD, LRS } \\
\qquad x=0\end{array}$ & $\begin{array}{l}\text { DEF } \\
x=3.25\end{array}$ & $\begin{array}{c}\text { ECT TO } \\
x=5.75\end{array}$ & $\begin{array}{l}\text { N S.1N. } \\
x=8.25\end{array}$ \\
\hline $\begin{array}{r}0.00 \\
.0 ?\end{array}$ & $\begin{array}{l}0.0 \\
0.0\end{array}$ & $\begin{array}{l}0.000000 \\
0.000000\end{array}$ & $\begin{array}{l}0.000000 \\
0.0000000\end{array}$ & $\begin{array}{l}0.000000 \\
0.000000\end{array}$ \\
\hline .04 & 400.0 & .000240 & OnOI?A & $.00000 \mathrm{~A}$ \\
\hline .06 & $600 . n$ & .001200 & - inO6284 & $.0001 \times 4$ \\
\hline .08 & 750.0 & .001240 & - InOOGEA & .000177 \\
\hline & $\begin{array}{l}750.0 \\
750.0\end{array}$ & $\begin{array}{l}.001320 \\
.001380\end{array}$ & $\begin{array}{l}-\cap 006 R A \\
.0007>0\end{array}$ & $\begin{array}{l}.000180 \\
.000184\end{array}$ \\
\hline .14 & $\begin{array}{l}750.0 \\
750.0\end{array}$ & $\begin{array}{l}.001425 \\
.001455\end{array}$ & $\begin{array}{l}\text { OnOO752 } \\
\text { OnOOT6R }\end{array}$ & $\begin{array}{l}.000128 \\
.000192\end{array}$ \\
\hline $.1 \mathrm{~A}$ & 750.0 & .001485 & - nOO & $.00019 A$ \\
\hline .20 & 750.0 & .001500 & .000800 & .000200 \\
\hline .22 & 0.0 & .001110 & - nCOSTA & $.00013 A$ \\
\hline .24 & 0.0 & .000570 & - $\cap 00416$ & .000060 \\
\hline & $\begin{array}{l}0.0 \\
0.0\end{array}$ & $\begin{array}{l}.00036 n \\
.000270\end{array}$ & $\begin{array}{l}\text {.nnO25a } \\
. \operatorname{nnn} 019 \text { ? }\end{array}$ & $\begin{array}{l}.000044 \\
.00002 A\end{array}$ \\
\hline $\begin{array}{l}.30 \\
.32\end{array}$ & $\begin{array}{l}0.0 \\
0.0\end{array}$ & $\begin{array}{r}.000210 \\
.000150\end{array}$ & $\begin{array}{l}\text { - } \cap \cap O 1 P R \\
\text { - } \cap \text { COOOAK }\end{array}$ & $\begin{array}{l}.00003 ? \\
.000004\end{array}$ \\
\hline .34 & 0.0 & .000120 & . OnOOOK & .000016 \\
\hline .36 & 0.0 & .000000 & - ONOOAA & $.000 \cap 0 R$ \\
\hline . 38 & 0.0 & .000060 & . $\cap 00032$ & $.00000 \Omega$ \\
\hline .40 & 0.0 & .000045 & . กnO0 32 & $.00000 R$ \\
\hline .42 & $0 . n$ & .000030 & .000032 & $.00000 R$ \\
\hline .44 & 0.0 & .000030 & . $\cap n 0032$ & $.0000 \cap R$ \\
\hline .46 & 0.0 & .000030 & - $\cap \cap 003 ?$ & $.00000 \Omega$ \\
\hline $.4 R$ & 0.0 & .000030 & . $\cap 00032$ & $.000 \cap \cap A$ \\
\hline .50 & 0.0 & .000030 & . $\cap \cap 0032$ & $.00000 A$ \\
\hline
\end{tabular}


1 I I 3

RESPONSE FUNCTIONS FROM IMPLICIT CONVOLITION

TIME RESPONSF FUNCTIONS

(SEC) $\quad x=3.25 \quad x=5.75 \quad x=A .25$

\begin{tabular}{|c|c|c|c|}
\hline $\begin{array}{r}0.000 \\
.020\end{array}$ & $\begin{array}{l}.00000160 \\
.00000787\end{array}$ & $\begin{array}{l}.000 n 0085 \\
.010000409\end{array}$ & $\begin{array}{l}.00000005 \\
.00000109\end{array}$ \\
\hline $\begin{array}{l}.040 \\
.060\end{array}$ & $\begin{array}{l}\text { - OnO000761 } \\
\text { OnNO00724 }\end{array}$ & $\begin{array}{l}.00000396 \\
.000 \cap 0378\end{array}$ & $\begin{array}{l}.00000105 \\
.00000100\end{array}$ \\
\hline $\begin{array}{l}.080 \\
.100\end{array}$ & $\begin{array}{l}.00000691 \\
.00000651\end{array}$ & $\begin{array}{l}.00000361 \\
.00000346\end{array}$ & $\begin{array}{l}.00000003 \\
.00000026\end{array}$ \\
\hline $\begin{array}{l}.120 \\
.140 \\
.160 \\
.1180\end{array}$ & $\begin{array}{l}\text { - ONO000606 } \\
\text { - ONO00564 } \\
\text { - ONO00517 } \\
\text { - ONO00270 }\end{array}$ & $\begin{array}{l}.00000321 \\
.00000299 \\
.00 \cap 00280 \\
.000 n \cap 111\end{array}$ & $\begin{array}{l}.000000 R 0 \\
.00000074 \\
.00000070\end{array}$ \\
\hline .200 & -.00000089 & .00000030 & $\begin{array}{r}.00000022 \\
\end{array}$ \\
\hline $\begin{array}{l}.220 \\
.240 \\
.260\end{array}$ & $\begin{array}{l}=00000150 \\
=00000124 \\
=.00000082\end{array}$ & $\begin{array}{l}=0000 \cap 0041 \\
=000 \cap n 044 \\
=0000 \cap 0046\end{array}$ & $\begin{array}{l}=000000021 \\
=00000011 \\
=000000006\end{array}$ \\
\hline .280 & $\because .00000048$ & $=.0 \operatorname{nn} 000>8$ & .000000 ก2 \\
\hline $\begin{array}{l}.300 \\
.320\end{array}$ & $\begin{array}{r}-.00000002 \\
.00000036\end{array}$ & $\begin{array}{r}=.00000014 \\
.00000007\end{array}$ & $\begin{array}{l}.00000001 \\
.00000003\end{array}$ \\
\hline $\begin{array}{l}.340 \\
.360\end{array}$ & $\begin{array}{l}.00000065 \\
.00000071\end{array}$ & $\begin{array}{l}.00000024 \\
.00000033\end{array}$ & .00000010 \\
\hline $\begin{array}{l}.390 \\
.400\end{array}$ & $\begin{array}{l}\text { O OnOOOOC45 } \\
\text { OnNOOOOO25 }\end{array}$ & $\begin{array}{l}.00000033 \\
.00000025\end{array}$ & $\begin{array}{l}.0000000 R \\
.00000005\end{array}$ \\
\hline $\begin{array}{l}.420 \\
.440\end{array}$ & $\begin{array}{l}.00000010 \\
.00000000\end{array}$ & $\begin{array}{l}\text {.nOONONO18 } \\
.00 \cap n \cap 0012\end{array}$ & $\begin{array}{l}.00000003 \\
.00000002\end{array}$ \\
\hline $\begin{array}{l}.460 \\
.480\end{array}$ & $\begin{array}{l}=.00000005 \\
\because .00000015\end{array}$ & $\begin{array}{r}.00000008 \\
-.00000005\end{array}$ & $\begin{array}{r}.00000001 \\
=.00000001\end{array}$ \\
\hline .500 & $=.0 n 000020$ & -.00000015 & $=.00000004$ \\
\hline
\end{tabular}


$1 M+3$

DEFLECTIONS FROM RESPONSF FIINCTIONG ANR LOAN

TIME LOAD,LFS, DEFLE\& T O N S.IN.

(SEC) $\quad x=0 \quad x=3.25 \quad x=5.75 \quad x=R, 75$

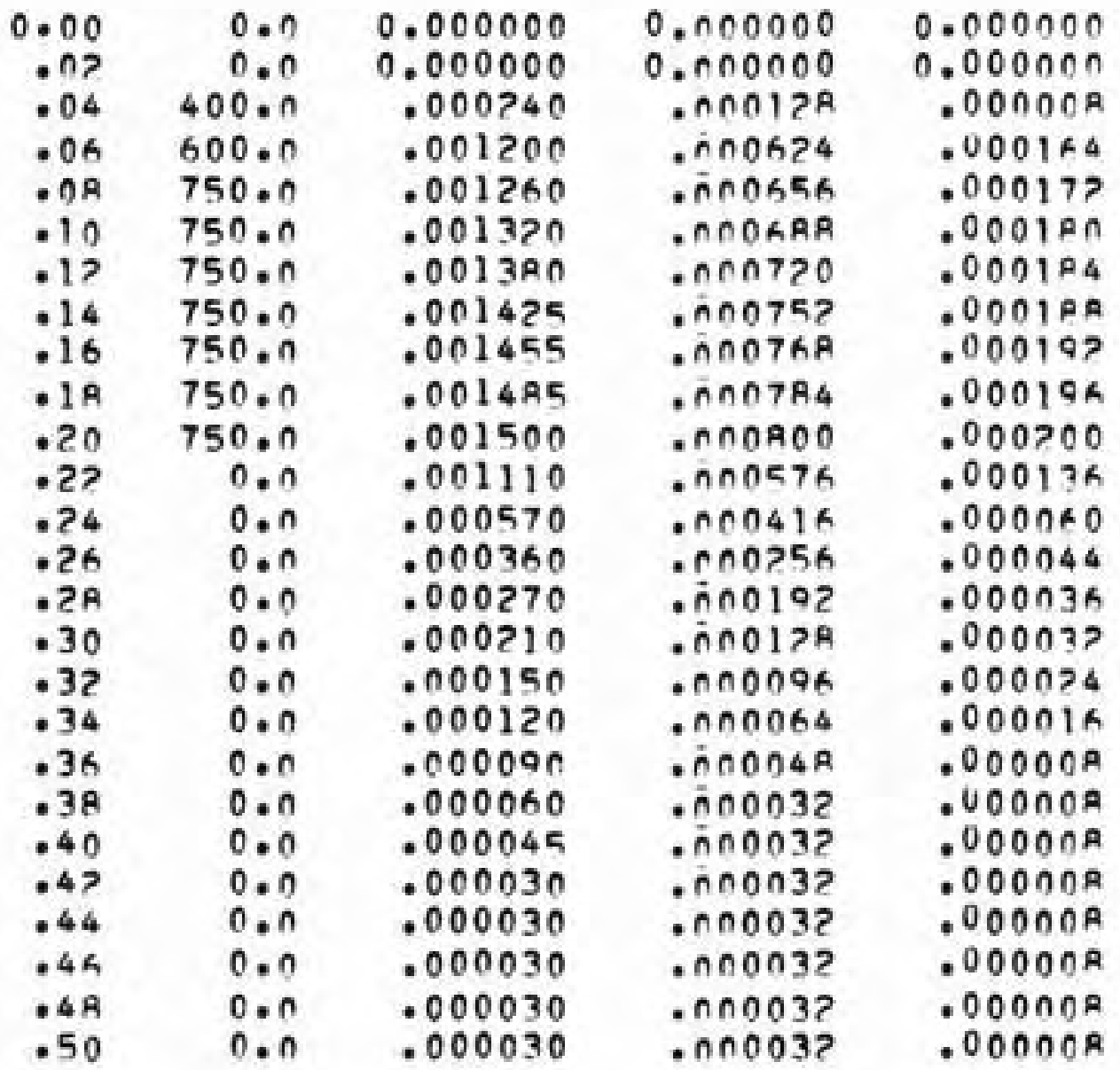


PECORN OF PAW MATA

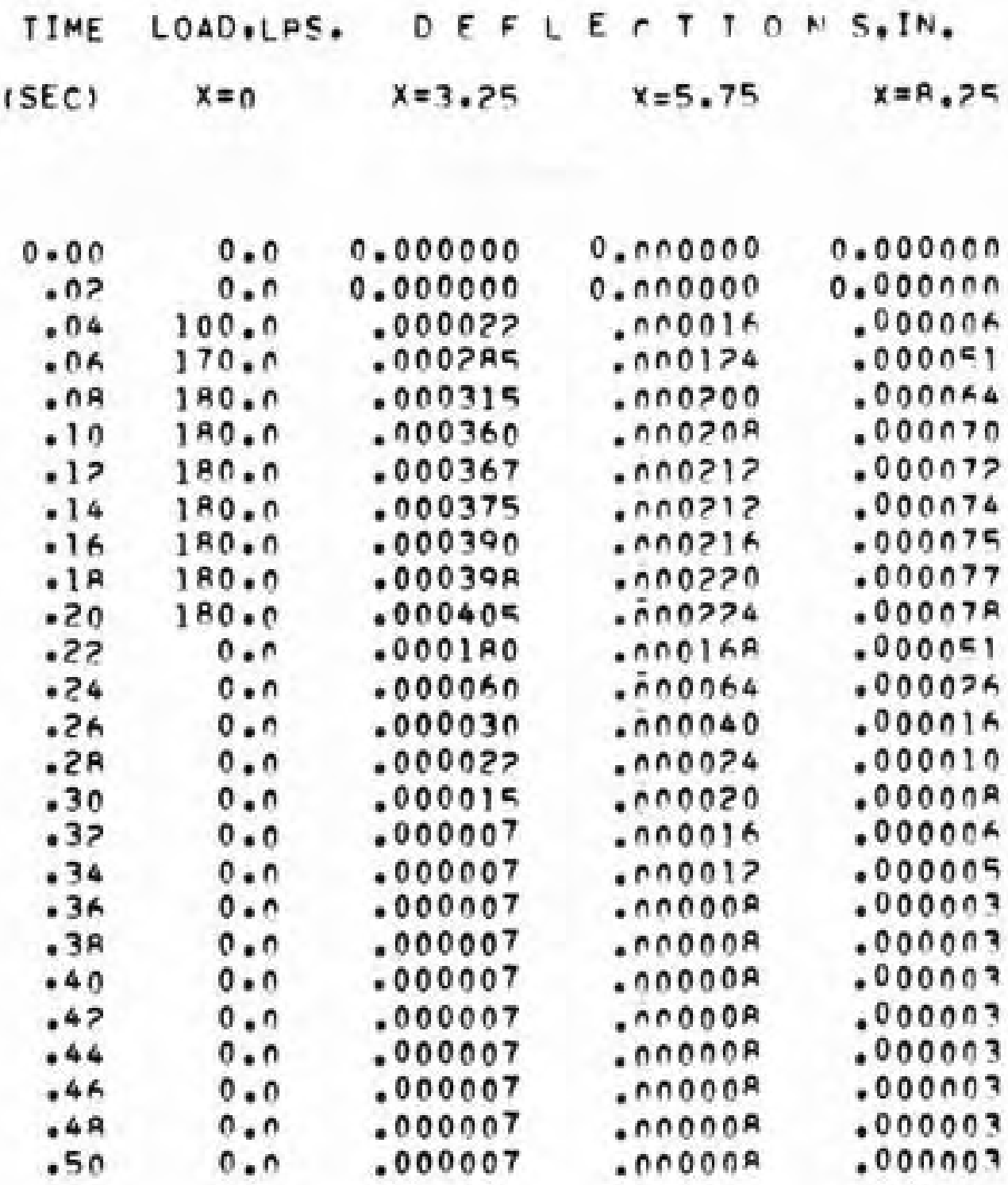


$1 \mathrm{HII}$

RESPONSE FUNCTIONS FROM INPITCIT CONVOLIITION

\begin{tabular}{|c|c|c|c|}
\hline $\begin{array}{l}\text { TIME } \\
\text { SEC) }\end{array}$ & $\begin{array}{l}R E S P C \\
x=3.25\end{array}$ & $\begin{array}{c}S F F U N \\
x=6.75\end{array}$ & $\begin{array}{l}10 \mathrm{NS} \\
x=8.25\end{array}$ \\
\hline $\begin{array}{r}0.000 \\
.0>0\end{array}$ & $\begin{array}{l}.00000062 \\
.010000786\end{array}$ & $\begin{array}{l}.000 n n 044 \\
.000 n 0340\end{array}$ & $\begin{array}{l}.00000018 \\
.00000141\end{array}$ \\
\hline $\begin{array}{l}.040 \\
.060\end{array}$ & $\begin{array}{l}.010000795 \\
.00000840\end{array}$ & $\begin{array}{l}.00000519 \\
.00000490\end{array}$ & $\begin{array}{l}.000001<3 \\
.000001<4\end{array}$ \\
\hline $\begin{array}{l}.090 \\
.100\end{array}$ & $\begin{array}{l}\text { OnO000777 } \\
\text { OnOOOOOZ20 }\end{array}$ & $\begin{array}{l}.00 \cap 0045 ? \\
.00 \cap n \cap 0407\end{array}$ & $\begin{array}{l}.00000152 \\
.0000014 ?\end{array}$ \\
\hline $\begin{array}{l}.120 \\
.140\end{array}$ & $\begin{array}{l}.00000689 \\
.00000641\end{array}$ & $\begin{array}{l}.00 n n 0377 \\
.00000350\end{array}$ & $\begin{array}{l}.000001332 \\
.00000133\end{array}$ \\
\hline .160 & - ONO00059R & - OCOnOZ3>6 & .00000115 \\
\hline $\begin{array}{l}.180 \\
.520\end{array}$ & $=00000332$ & - OAnAnisa & $\because 00000071$ \\
\hline $\begin{array}{l}.220 \\
.240\end{array}$ & -.00000210 & $=\cos 0114$ & $\because 00000036$ \\
\hline & & & $\begin{array}{l}=00000 n \geqslant ? \\
=00000010\end{array}$ \\
\hline .300 & - ONONO000 & $\because 000 \cap 0001$ & .00000000 \\
\hline $\begin{array}{l}.320 \\
.340 \\
.360\end{array}$ & $\begin{array}{l}.00000073 \\
.01000126 \\
.00000105\end{array}$ & $\begin{array}{l}.000 \cap 0023 \\
.00 \cap A \cap 053 \\
.000 \cap 0062\end{array}$ & $\begin{array}{l}.0000000 R \\
.00000019 \\
.00000070\end{array}$ \\
\hline $\begin{array}{l}.390 \\
.400 \\
.420 \\
.440\end{array}$ & $\begin{array}{r}.00000061 \\
.00000025 \\
.00000001 \\
-.00000012\end{array}$ & 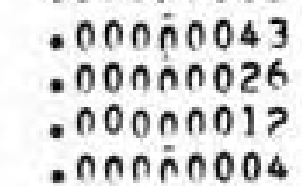 & $\begin{array}{l}.00000015 \\
.00000010 \\
.00000005 \\
.00000007\end{array}$ \\
\hline .460 & -.00000018 & .00000000 & .00000001 \\
\hline .490 & -.00000026 & -.00000011 & -.00000003 \\
\hline .500 & $=.00000026$ & $=.000 \cap 0019$ & -.00000007 \\
\hline
\end{tabular}


$1 H I 1$

DEFLECTIONS FROM RFSPONSF FIINCTIONS ANO LOAN

TIME LOAD,LRS, $\quad$ DEFLECT T N S,IN.
(SEC) $\quad x=0 \quad x=3.25 \quad x=5.75 \quad x=8.25$

\begin{tabular}{|c|c|c|c|c|}
\hline 0.00 & 0.0 & 0.000000 & $0 . \cap 00000$ & 0.000000 \\
\hline .07 & 0.0 & 0.000000 & 0.000000 & $0.0000 \cap 0$ \\
\hline .04 & $\begin{array}{l}100.0 \\
170.0\end{array}$ & $\begin{array}{l}.000022 \\
.000285\end{array}$ & 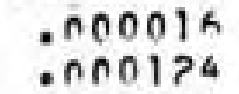 & $\begin{array}{l}.00000 K \\
.0000 E 1\end{array}$ \\
\hline I $\cap A$ & $180 . n$ & .000315 & - AnกP DO & $.000 n \times 4$ \\
\hline .10 & $180 \cdot 0$ & .000360 & - $\cap \cap 0 Z 0 R$ & .000070 \\
\hline .17 & 180.0 & .000367 & - $\cap 10212$ & $.00007 ?$ \\
\hline .14 & $18 \cap \cdot 0$ & $.0 \cap 0375$ & - $\cap \cap 0 ? 12$ & .000074 \\
\hline .16 & 180.0 & .000390 & - $\cap \cap 0>16$ & .000075 \\
\hline .18 & 180.0 & .000397 & - $\cap \cap 0220$ & .000077 \\
\hline .20 & $190 \cdot 0$ & .000405 & . $n n 0224$ & .000078 \\
\hline .27 & 0.0 & $.0001 \mathrm{RC}$ & - $\cap \cap O 1 R R$ & .000051 \\
\hline .24 & 0.0 & .000060 & .000064 & $.000 n>a$ \\
\hline .24 & 0.0 & .000030 & .000040 & .000016 \\
\hline - 29 & $0 . n$ & .000023 & - nnOOPZ & .000ก10 \\
\hline . 30 & 0.0 & .000015 & .000020 & $.00 \cap \cap 0 A$ \\
\hline -3? & $0 . n$ & .000007 & - nnOOIR & $.000 \cap 0 R$ \\
\hline .34 & $0 . n$ & $.00000 \mathrm{R}$ & $=\pi \cap 001 ?$ & .000005 \\
\hline .36 & $0 . n$ & $.000 \cap 07$ &.$\cap \cap O O O R$ & .000003 \\
\hline - 3R & $0 . n$ & .000007 & . $\cap \cap 000 R$ & .000003 \\
\hline .40 & 0.0 & .000007 & . $\cap \cap O O \cap R$ & .000007 \\
\hline .47 & 0.0 & .000007 & .000008 & .000003 \\
\hline .44 & $0 . n$ & .000007 & . ANDOAA & .000003 \\
\hline .46 & 0.0 & .000007 & . $\cap \cap O O O A$ & .000003 \\
\hline $.4 R$ & 0.0 & .000008 & . $\cap \cap O O \cap R$ & .000003 \\
\hline $.5 n$ & 0.0 & .000008 &.$\cap 0000 A$ & .000007 \\
\hline
\end{tabular}


RECORD OF RAW DATA

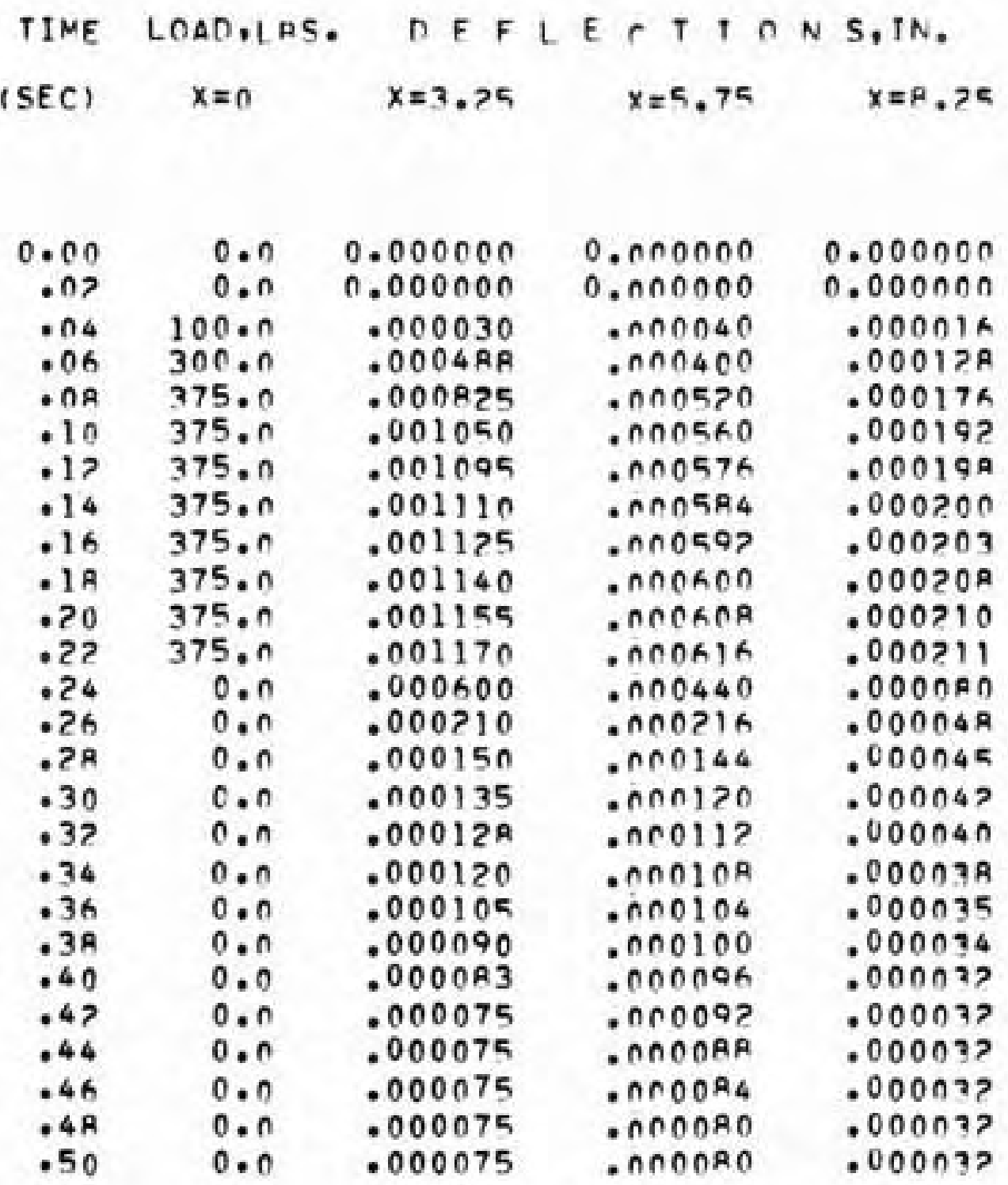


JHI?

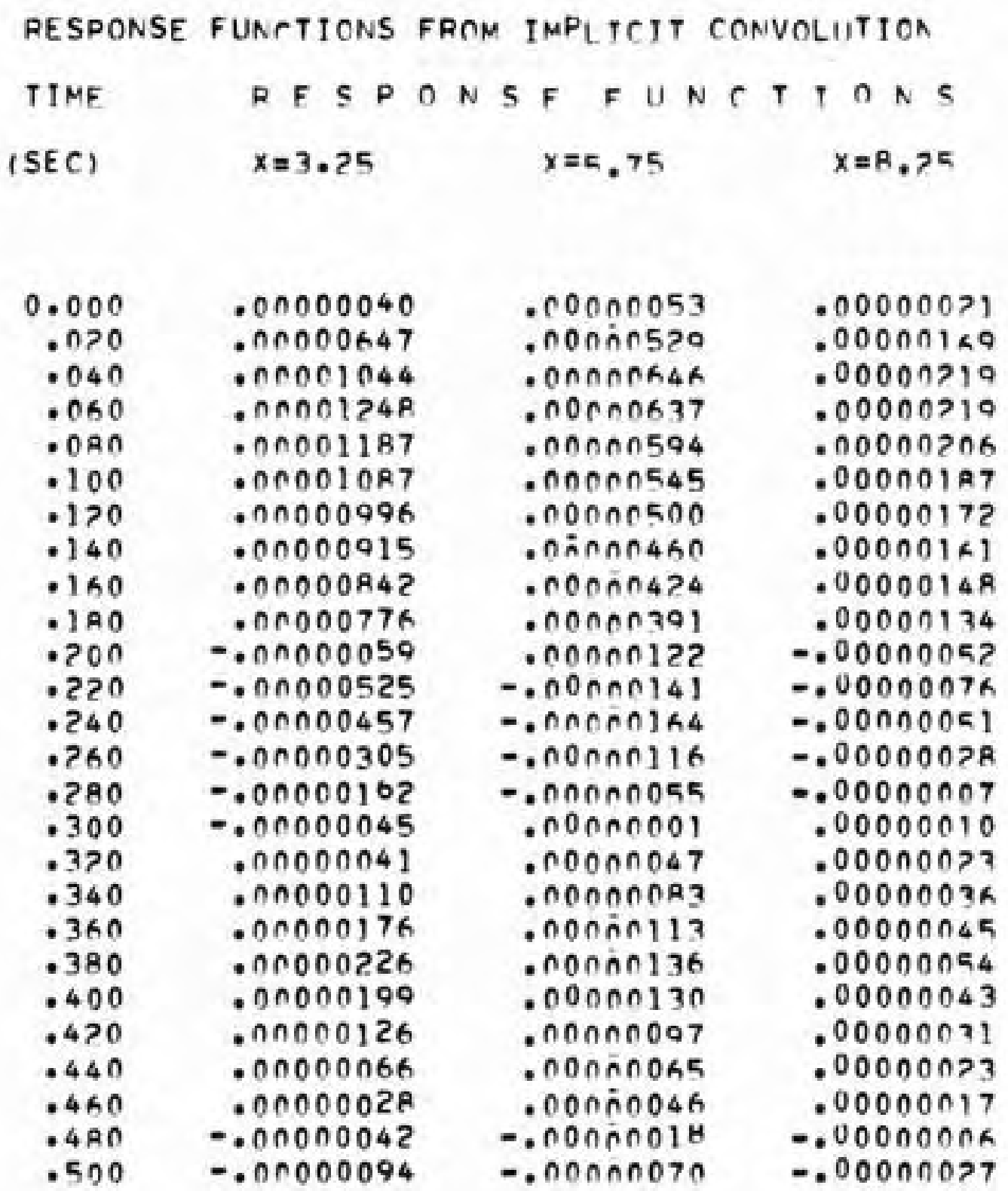


IHT?

DEFLECTIONE FROM RFSPONSF FIINCTTONS ANO IOAR

TIME LOAD,LAS, DFFLE $P T$ T N S,IN.
(SEC) $\quad x=0 \quad x=3.25 \quad x=5.75 \quad x=8.25$

\begin{tabular}{|c|c|c|c|c|}
\hline 0.00 & 0.0 & 0.000000 & $0 . \cap \cap 0000$ & $0.000 \cap n \cap$ \\
\hline .02 & 0.0 & 0.000000 & $0 . \cap \cap 0 \cap 00$ & $0.00000 \mathrm{n}$ \\
\hline $\begin{array}{l}.04 \\
.04\end{array}$ & $\begin{array}{l}100 \cdot 0 \\
300 \cdot 0\end{array}$ & $\begin{array}{l}.000030 \\
.0004 R A\end{array}$ & $\begin{array}{l}. \cap \cap 00 \angle 0 \\
.0 \cap 0400\end{array}$ & $\begin{array}{l}.00001 R \\
.00012 R\end{array}$ \\
\hline - OA & $375 \cdot n$ & - OCOR2E & - $A \cap \cap 5=0$ & .000175 \\
\hline .10 & $375 . n$ & $.00105 n$ & . $n 0 \cap 56 n$ & $.00019 ?$ \\
\hline .17 & $375 \cdot n$ & .001095 & . $n 0057 R$ & .000108 \\
\hline .14 & $\begin{array}{l}375 . n \\
375 . n\end{array}$ & $\begin{array}{l}.001110 \\
.001125\end{array}$ & 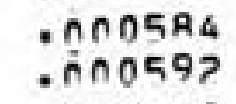 & $\begin{array}{l}.000>00 \\
.000>07\end{array}$ \\
\hline $\begin{array}{l}.19 \\
.20\end{array}$ & $\begin{array}{l}375 \cdot n \\
375 . n\end{array}$ & $\begin{array}{l}.001140 \\
.001155\end{array}$ & $\begin{array}{l}-\cap \cap O R O O \\
. \triangle O O B O R\end{array}$ & $\begin{array}{l}.000208 \\
.000211\end{array}$ \\
\hline .22 & 375.0 & .001170 & - AnOGIS & .000211 \\
\hline .24 & $0 . n$ & .000600 & $.0 \cap 0440$ & .000080 \\
\hline .26 & $0 \cdot n$ & .000210 & - An0? & $.00004 A$ \\
\hline $\begin{array}{l}.28 \\
.30\end{array}$ & $\begin{array}{l}0.0 \\
0.0\end{array}$ & $\begin{array}{l}.000150 \\
.000135\end{array}$ & $\begin{array}{l}\text { - } \cap 00144 \\
\text { - } \cap \cap 01>0\end{array}$ & $\begin{array}{l}.000045 \\
.00004 ?\end{array}$ \\
\hline $\begin{array}{l}.37 \\
.34\end{array}$ & $\begin{array}{l}0 . n \\
0 . n\end{array}$ & $\begin{array}{l}.00012 R \\
.000120\end{array}$ & $\begin{array}{l}\text {-AOO11? } \\
\text {-OAO1OR }\end{array}$ & $\begin{array}{l}.000 \cap 40 \\
.00003 A\end{array}$ \\
\hline - 36 & $0 \cdot n$ & .000105 & - $n \cap 0104$ & .000035 \\
\hline - 38 & $0 \cdot n$ & .000090 & - nnolno & .000034 \\
\hline .40 & $0 \cdot n$ & .000083 & - ANONQA & .000027 \\
\hline .47 & 0.0 & .000075 & . $\cap \cap 0 \cap Q ?$ & $.00003 ?$ \\
\hline .44 & $0 \cdot n$ & .000075 & - ONOORR & .000037 \\
\hline .46 & $0 \cdot n$ & .000075 & - $\cap \cap 000^{R 4}$ & $.00003 ?$ \\
\hline $\begin{array}{l}.48 \\
.50\end{array}$ & $\begin{array}{l}0.0 \\
0.0\end{array}$ & $\begin{array}{r}.000075 \\
.000075\end{array}$ & 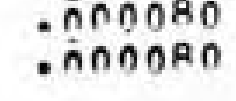 & $\begin{array}{l}.000037 \\
.000033\end{array}$ \\
\hline
\end{tabular}


IHT?

RECORA OF RAW DATA

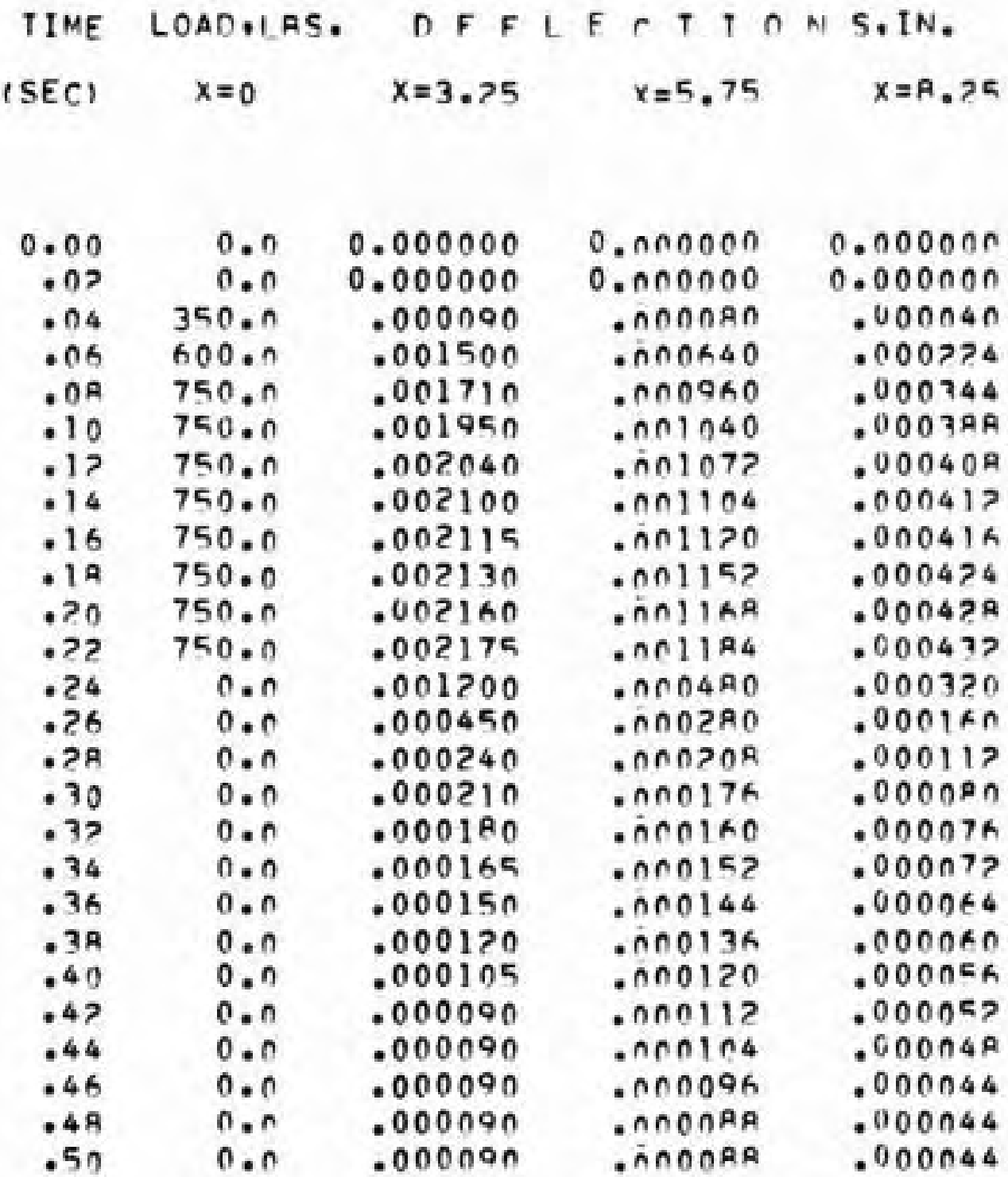


RESPONSE FUNCTIONS FROM TMPI ICIT CONVOLIITION

TIME

(SEC) A E SPON S

$x=3.25$

$x=5.75$

$x=8,>25$

\begin{tabular}{|c|c|}
\hline 0.000 & .00000060 \\
\hline $.0>0$ & . $0 ก 000995$ \\
\hline .040 & .00001054 \\
\hline .060 & . กกก01110 \\
\hline $.0 A 0$ & .00001060 \\
\hline$\cdot 100$ & . คกคก0993 \\
\hline .120 & $.0 n 000903$ \\
\hline .140 & .00000820 \\
\hline .160 & $.0 \cap 000757$ \\
\hline .190 & .00000690 \\
\hline - 200 & - 00000024 \\
\hline .220 & $=\operatorname{nn} 000437$ \\
\hline .240 & $-.0 n 000436$ \\
\hline .260 & $=.00000301$ \\
\hline - 290 & $=.00000182$ \\
\hline .300 & $=.0 \cap 000073$ \\
\hline .320 & . $n \cap 000017$ \\
\hline .340 & .00000079 \\
\hline .360 & $.0 \cap 000138$ \\
\hline $.3 A 0$ & - $\cap 00 \cap 0185$ \\
\hline .400 & $.0 \cap 000165$ \\
\hline $.42 n$ & .00000104 \\
\hline .440 & .00000049 \\
\hline .460 & . $0 n 000013$ \\
\hline .480 & - 00000037 \\
\hline .500 & $\because 00000072$ \\
\hline
\end{tabular}

$.000 \operatorname{RnOS3}$

. กคกกก4??

- nOOAn601

- OCnAnEar

. conninse

. OnOAnE?

. $\cap O \cap \cap \cap 4 R 1$

- nnOBNAF

- nocnodia

- N0OAnZR7

-. กnกกกIIT

-. nnonozor

-. OOOAn175

- oconanila

- DONAROGO

- ononcosa

- nonanoza

- onnnanota

- conaniog

- conanalza

- noninnoos

- nonnnoso

- nOOnOOZZ

- onononta

-.00000023

- onnnODEs?
$.000000>7$

.00000147

$.00000>15$

$.00000>>4$

$.00000>15$

.00000196

. $000 n n i>0$

. 000001á

.000001 a

.000nniza

.000nonaz

-. $0000004 A$

. $0000 n$ ODE

-.000nonar

-.000non?4

. $0000000 n 4$

. 000nonRa

$.000000>3$

.00000073

.00000041

.00000040

$.000 n 0 n>0$

$.000000>0$

.00000013

. .00000005

$-.00000 n>0$ 
IHI 2

DEFLECTIONS FROM RESPONSF FIINCTIONS AND LOAD

TIME LOAD,LDS. DEFIECT TON S.IN.
(SEC) $x=0 \quad x=3.25 \quad x=5.75 \quad x=8.25$

\begin{tabular}{|c|c|c|c|c|}
\hline 0.00 & 0.0 & 0.000000 & 0.000000 & 0.000000 \\
\hline . $0 ?$ & $0 . n$ & 0.000000 & $0 . \cap \cap O \cap \cap 0$ & 0.000000 \\
\hline .04 & 350.0 & .000090 & - AnODRO & $.000 \cap 40$ \\
\hline $\begin{array}{l}.06 \\
.09\end{array}$ & $\begin{array}{l}600.0 \\
750.0\end{array}$ & $\begin{array}{l}.001500 \\
.001710\end{array}$ & 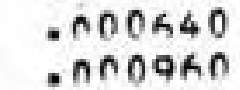 & $\begin{array}{l}.0002 \geqslant 4 \\
.000344\end{array}$ \\
\hline $\begin{array}{l}.19 \\
.13\end{array}$ & $\begin{array}{l}750.0 \\
750.0\end{array}$ & $\begin{array}{l}.001950 \\
.002040\end{array}$ & $\begin{array}{l}.0 \cap 1040 \\
.0 \cap 107 \%\end{array}$ & $\begin{array}{l}.0003 R R \\
.00040 R\end{array}$ \\
\hline .14 & $\begin{array}{l}750.0 \\
750.0\end{array}$ & $\begin{array}{l}.002100 \\
.0021115\end{array}$ & $\begin{array}{l}n \cap 1104 \\
.0 n 11 \geqslant 0\end{array}$ & $\begin{array}{l}.00041 ? \\
.00041 \%\end{array}$ \\
\hline - 19 & 750.0 & $\begin{array}{l}.002130 \\
.002140\end{array}$ & $\begin{array}{l}\text { On1152 } \\
\text { On }\end{array}$ & $\begin{array}{l}.000424 \\
.0004>9\end{array}$ \\
\hline.$? 7$ & 750.0 & .002175 & . $\cap \cap 1 \mid R 4$ & .000437 \\
\hline .24 & 0.0 & .001200 &.$\cap \cap 04 \mathrm{HO}$ & .000320 \\
\hline - ?A & $0 . n$ & .000450 & . $\cap \cap 0>R O$ & $.0001 \mathrm{KO}$ \\
\hline -29 & $0 . n$ & .000240 & - $\cap \cap \cap P \cap A$ & .000117 \\
\hline .30 & $0 . n$ & .000210 &.$n \cap 0176$ & .000 OAn \\
\hline - 32 & $n \cdot n$ & .000180 & - AnOIAO & $.000 \cap 76$ \\
\hline .34 & 0.0 & .000165 & $.00015 ?$ & .000077 \\
\hline $\begin{array}{l}.36 \\
.39\end{array}$ & $\begin{array}{l}n=n \\
n . n\end{array}$ & $\begin{array}{l}.00015 n \\
.000120\end{array}$ & 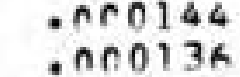 & $\begin{array}{l}.000004 \\
.0000 R\end{array}$ \\
\hline .40 & 0.0 & .000105 & $. \cap \cap 01>0$ & . OnOnEA \\
\hline .47 & $0 . n$ & .000090 & . & $.00005 ?$ \\
\hline .44 & $0 . n$ & .000090 & .000104 & $.000 \cap 4 \mathrm{~A}$ \\
\hline .46 & 0.0 & .000000 & - nconos & $.000 \cap 44$ \\
\hline .48 & 0.0 & .000090 & - $\cap \cap O O A R$ & $.000 \cap 44$ \\
\hline .50 & 0.0 & .000000 & - ANOORA & .000044 \\
\hline
\end{tabular}


RECOPD OF PAW DATA

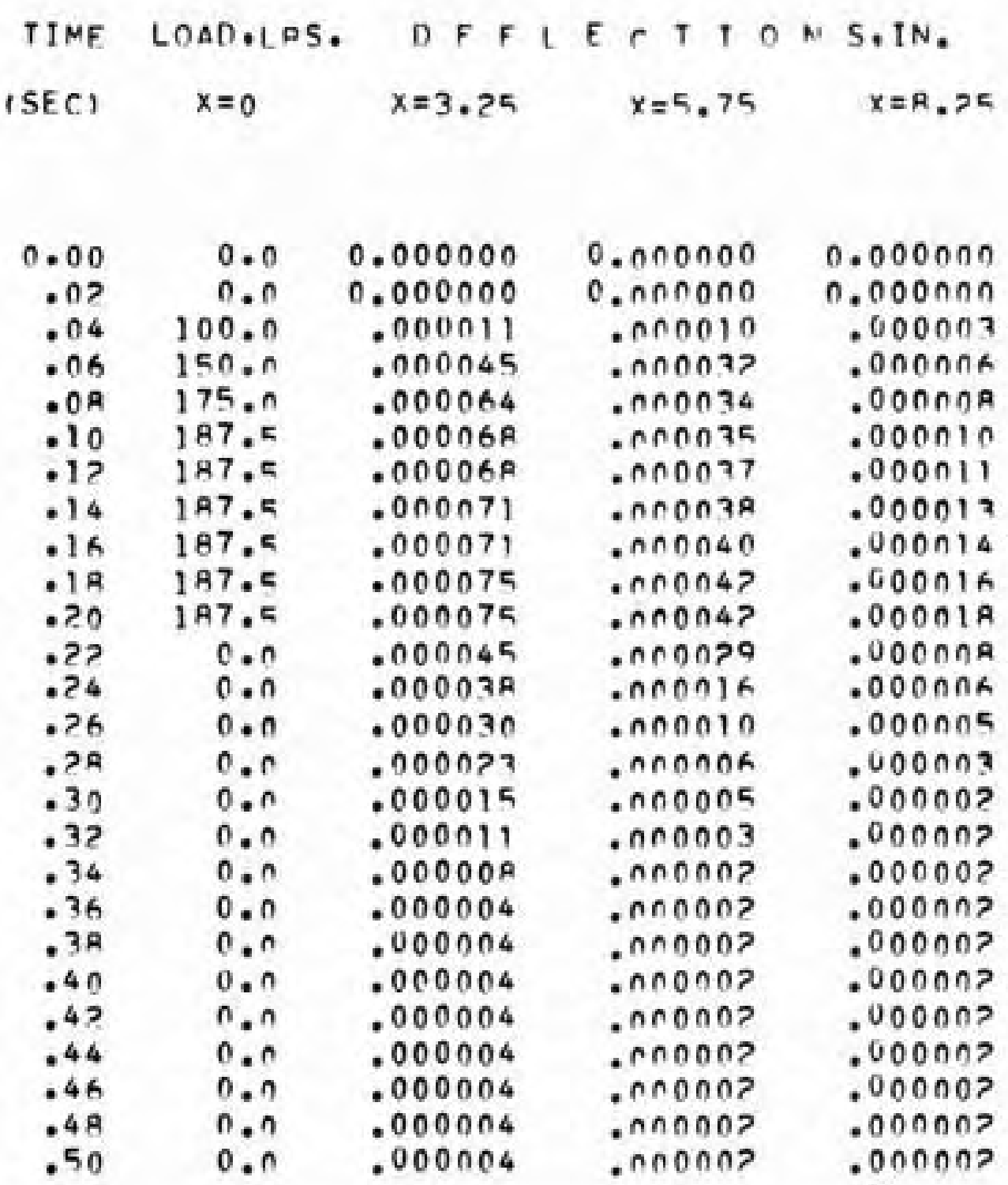


RESPONSE FUNCTIONS FROM TMPITCIT CONVOLITIOA

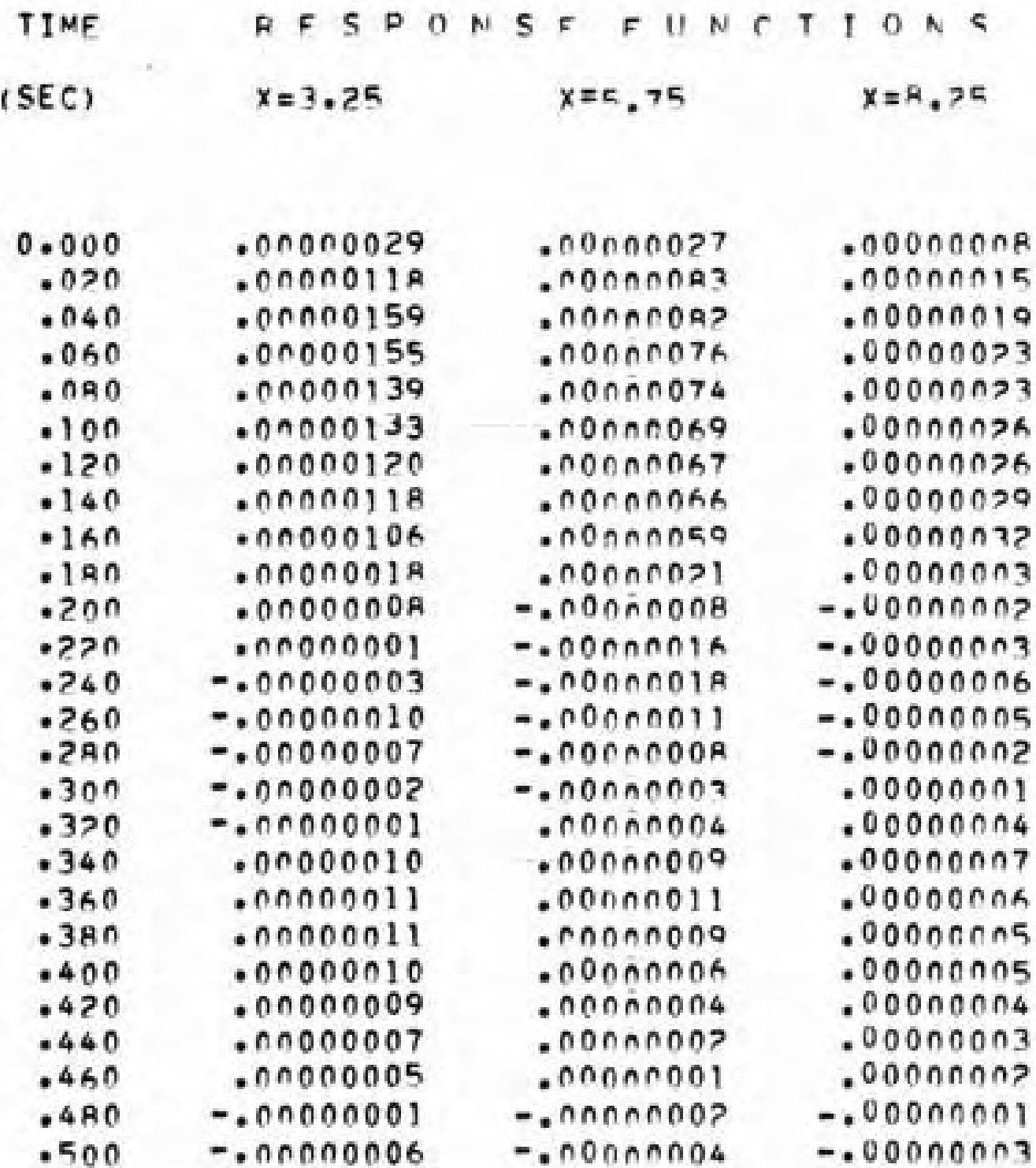


PLTI

DFFLECTIONE FROM RESPONSF FIINCTIONS ANO I TAR

\begin{tabular}{|c|c|c|c|c|}
\hline SEC) & $x=0$ & $x=3.25$ & $x=5.75$ & $x=8, ?$ \\
\hline $\begin{array}{r}0.00 \\
.07\end{array}$ & $\begin{array}{l}0.0 \\
0.0\end{array}$ & $\begin{array}{l}0.000000 \\
0.000000\end{array}$ & $\begin{array}{l}0.000000 \\
0.000000\end{array}$ & $\begin{array}{l}0.000000 \\
0.000000\end{array}$ \\
\hline $\begin{array}{l}.04 \\
\text { ing }\end{array}$ & $\begin{array}{l}100.0 \\
150.0\end{array}$ & $\begin{array}{l}.000011 \\
.000045\end{array}$ & $\begin{array}{l}.000010 \\
.00003 ?\end{array}$ & $\begin{array}{l}.000007 \\
.00000 R\end{array}$ \\
\hline .08 & $\begin{array}{l}175.0 \\
187.5\end{array}$ & .000064 & - $\cap 00034$ & $\begin{array}{l}.00000 A \\
.000010\end{array}$ \\
\hline $\begin{array}{l}.10 \\
\because 17\end{array}$ & 187.5 & .000068 & $\begin{array}{l}0 \cap 0035 \\
: 0 n 0037\end{array}$ & $\begin{array}{l}.000010 \\
.000011\end{array}$ \\
\hline & $\begin{array}{l}187.5 \\
187.5\end{array}$ & $\begin{array}{l}.000071 \\
.000071\end{array}$ & $\begin{array}{l}\operatorname{nnOn} 38 \\
. \operatorname{nnOOS} 0\end{array}$ & $\begin{array}{l}.000013 \\
.000014\end{array}$ \\
\hline $.1 A$ & 187.5 & .000075 & $.0 \cap 004$ ? & .000016 \\
\hline .20 & 187.0 & .000075 & .000042 & .000019 \\
\hline $.2 ?$ & $0 . n$ & .000045 &. $\operatorname{nn} 0020$ & .000008 \\
\hline .74 & $0 . ?$ & .000038 & . nnOOIA & $.00000 \mathrm{~A}$ \\
\hline .26 & 0.0 & .000030 & ח ח & .000005 \\
\hline . $>A$ & $n \cdot n$ & $.000 \cap>2$ & - coonna & .000003 \\
\hline - 30 & 0.0 & .000015 & $=000005$ & $\begin{array}{l}.000002 \\
.000002\end{array}$ \\
\hline .37 & $\begin{array}{l}0.0 \\
0.0\end{array}$ & $\begin{array}{l}.000011 \\
.000008\end{array}$ & $\begin{array}{l}.000003 \\
: 00000000\end{array}$ & $\begin{array}{l}.00000 \\
.00000 ?\end{array}$ \\
\hline .36 & 0.0 & .000004 & כחתח & $.00000 ?$ \\
\hline . $3 R$ & $0 . n$ & .000004 & OAnOAOZ & $.00000 ?$ \\
\hline .40 & 0.0 & .000004 & $\cdot 00000$ ? & .000007 \\
\hline .47 & 0.0 & .000004 & . $\cap 0000$ ? & $.000 \cap n ?$ \\
\hline .44 & 0.0 & .000004 & $\cdot 000 \cap 0 ?$ & - 0000ก? \\
\hline $8 \mathrm{n}$ & 0.0 & $.000 \cap 04$ & . & $.000 \cap 07$ \\
\hline .48 & 0.0 & .000004 & - $\cap 0000$ ? & $\begin{array}{l}.000000 \\
.00000 ?\end{array}$ \\
\hline
\end{tabular}


PLT?

RECORN OF RAW TATA

\begin{tabular}{|c|c|c|c|c|}
\hline $\begin{array}{l}\text { TIME } \\
\text { (SEC) }\end{array}$ & $\begin{array}{l}\text { LOAD, LRS. } \\
\qquad x=0\end{array}$ & $\begin{array}{c}D F F \\
x=3.25\end{array}$ & $\begin{array}{r}E \subset T 10 \\
x=5.75\end{array}$ & $\begin{array}{l}\quad S, I N . \\
x=R .>2\end{array}$ \\
\hline $\begin{array}{r}0.00 \\
.07\end{array}$ & $\begin{array}{l}0.0 \\
0.0\end{array}$ & $\begin{array}{l}0.000000 \\
0.000000\end{array}$ & $\begin{array}{l}0 . \cap 00000 \\
0 . \cap 00000\end{array}$ & $\begin{array}{l}0.000000 \\
0.000000\end{array}$ \\
\hline .04 & $200 . n$ & .000023 & . AnOOOK & .000005 \\
\hline .06 & 350.0 & .000045 & .000010 & $.00000 \mathrm{~A}$ \\
\hline .08 & $\begin{array}{l}375.0 \\
375.0\end{array}$ & $\begin{array}{l}.000090 \\
.000113\end{array}$ & $\begin{array}{l}\operatorname{nnnO038} \\
\operatorname{nnn} 0054\end{array}$ & $\begin{array}{l}.000 n i n \\
.000016\end{array}$ \\
\hline .12 & $375 . n$ & .000124 & - nกOOTO & $.000 n 21$ \\
\hline .14 & 375.0 & $.00012 R$ & . ANDOAOO & $.0000 \geqslant 4$ \\
\hline .16 & $375 . n$ & .000131 &.$\cap \cap_{0} O \mathrm{~B}_{3}$ & .000026 \\
\hline - 18 & $375 . n$ & .000139 & . AnOORE & .000027 \\
\hline .20 & $375 . n$ & .000143 & . AnOORA & $.000 n \geqslant 0$ \\
\hline .?? & 0.0 & .000090 & - NOOOAT & $.00002 ?$ \\
\hline .24 & 0.0 & .000083 & $.0 \cap 0054$ & .000019 \\
\hline $.2 \mathrm{~A}$ & 0.0 & .000045 & $.0 n 0026$ & .000008 \\
\hline $.2 B$ & $0 . n$ & .000030 & . nnO01a & .000005 \\
\hline .30 & 0.0 & $.000 \cap 26$ & .000013 & $.000 \cap 03$ \\
\hline .37 & 0.0 & .000023 & .000010 & $.00000 ?$ \\
\hline .34 & 0.0 & .000010 &.$\cap O D O O A$ & .000 nn? \\
\hline .36 & 0.0 & .000015 &.$\cap 0000 A$ & .000007 \\
\hline $.3 A$ & $0 . n$ & .000011 & . 000005 & $.000 \cap 0 ?$ \\
\hline .40 & $c . n$ & .000008 & .000003 & .000007 \\
\hline $.4 ?$ & $n .0$ & $.00000 \mathrm{~A}$ & $=0 \cap 000 ?$ & .000007 \\
\hline .44 & 0.0 & $.00000 \mathrm{~A}$ & .000002 & .000007 \\
\hline .46 & 0.0 & $.000 \cap 0 A$ & - $\cap 00 \cap 0$ ? & $.000 \cap \cap 2$ \\
\hline $.4 R$ & 0.0 & $.00000 R$ & - $0 \cap 000$ ? & .000002 \\
\hline .50 & 0.0 & .000008 & . $\cap \cap 00 \cap$ ? & $.00000 ?$ \\
\hline
\end{tabular}


RESPONSF FUNCTIONS FROM IMPI TCIT CONVOLITIOA

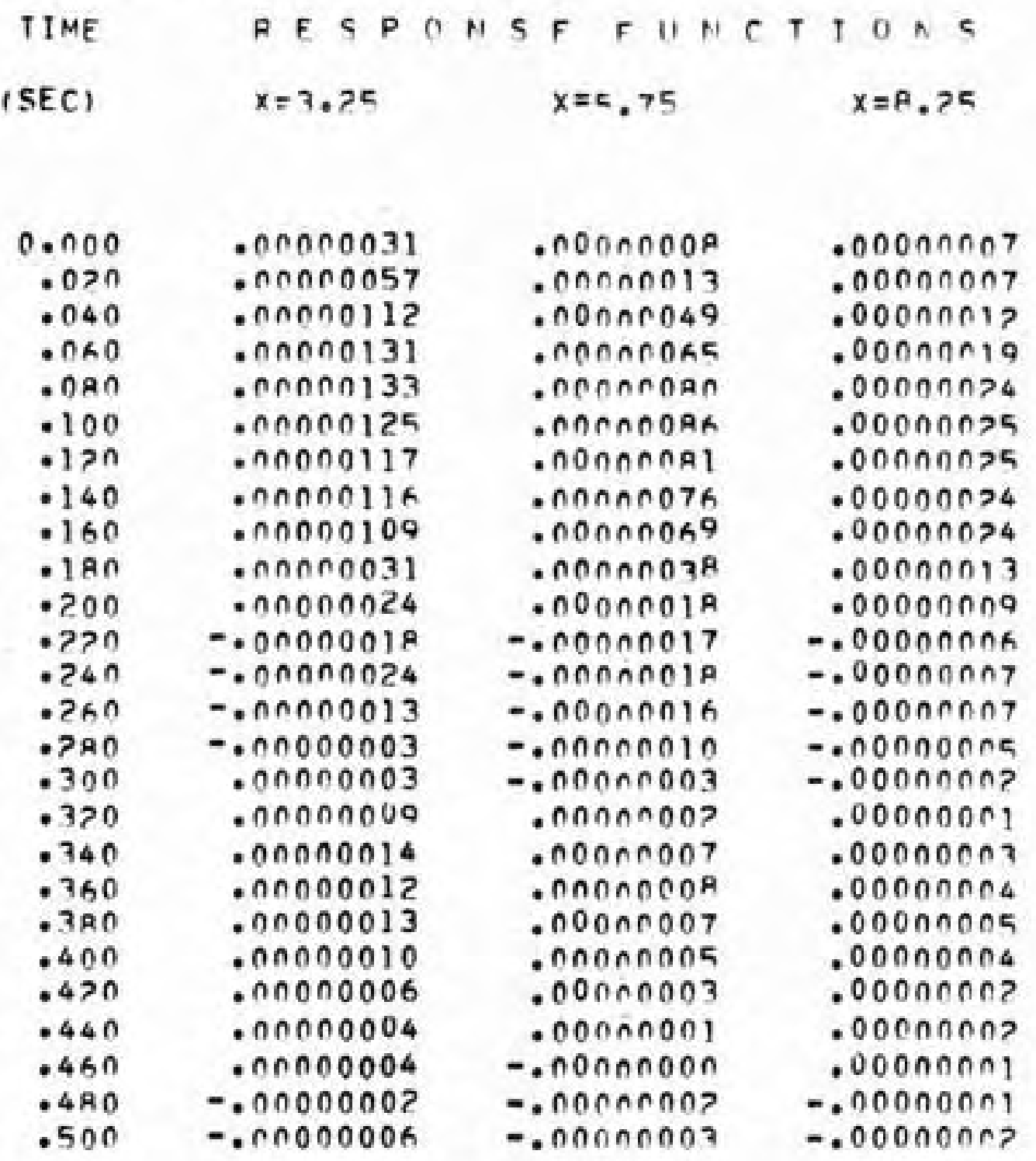




\section{PLIT}

DEFLECTIONS FROM RESPONSE FIINCTIONS ANO LRAN

\begin{tabular}{|c|c|c|c|c|}
\hline $\begin{array}{l}\text { TIME } \\
\text { SEC) }\end{array}$ & $\begin{array}{l}\text { LOAD LAS. } \\
\qquad x=0\end{array}$ & $\begin{array}{l}D E F \\
X=3.25\end{array}$ & $\begin{array}{l}E \subset T T \\
x=5.75\end{array}$ & $\begin{array}{l}\text { N S,IN. } \\
\quad x=R, ?=\end{array}$ \\
\hline 0.00 & 0.0 & 0.000000 & 0.000000 & 0.000000 \\
\hline .02 & 0.0 & 0.000000 & $0 . \cap \cap 0000$ & $0.0000 \cap 0$ \\
\hline .04 & $200 . n$ & .000023 & - nnONOK & .00000 \\
\hline .06 & 350.0 & .000045 & . & $.00000 \mathrm{~A}$ \\
\hline.$O R$ & 375.0 & $.00009 n$ & - nnOAZR & $.000 n 10$ \\
\hline .10 & $375 . n$ & .000113 & .000054 & .000016 \\
\hline 12 & $\begin{array}{l}375.0 \\
375.0\end{array}$ & $\begin{array}{l}.000124 \\
.000129\end{array}$ & $\begin{array}{l}-\cap \cap 0070 \\
\triangle \cap O O \cap A 0\end{array}$ & $\begin{array}{l}.000 \cap \geqslant 1 \\
.0000 \geqslant 4\end{array}$ \\
\hline .16 & $375 . n$ & .000131 & - ONOOA3 & - 00002 \\
\hline$\cdot 18$ & $375 \cdot n$ & .000139 & - AnOARE & .000027 \\
\hline .20 & 375.0 & .000143 & - $\cap \cap \cap \cap \cap B$ & - 0 OnOn>0 \\
\hline .22 & 0.0 & .000090 & $.0 \cap 0067$ & $.00 \cap \cap>?$ \\
\hline .24 & 0.0 & $.000 \cap 83$ & .000054 & .000019 \\
\hline .26 & 0.0 & .000045 & $.00002 A$ & $.000 \cap \cap 8$ \\
\hline .28 & $0 . n$ & .000030 & . 000019 & .000005 \\
\hline .30 & 0.0 & .000026 & $.0 n 0013$ & $.0000 n 3$ \\
\hline .32 & 0.0 & .000023 &.$\cap \cap 0010$ & $.00000 ?$ \\
\hline .34 & $0 . n$ & .000019 & - חOOOAR & $.00000 ?$ \\
\hline - 36 & 0.0 & .000015 &.$\cap 00006$ & .000007 \\
\hline .38 & $\begin{array}{l}0.0 \\
0.0\end{array}$ & $\begin{array}{l}.000011 \\
.000008\end{array}$ & 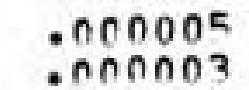 & $\begin{array}{l}.00000 ? \\
.000 \cap 0 ?\end{array}$ \\
\hline .42 & 0.0 & .000008 & - חחBOח & $.0000 \cap 7$ \\
\hline .44 & $0 . n$ & .000008 & - $\cap \cap 0 \cap 00$ ? & .000007 \\
\hline .46 & $0 . n$ & .000008 & - $\cap \cap \cap 0 \cap 2$ & . $00 \cap \cap \cap 02$ \\
\hline .48 & 0.0 & .000008 & ?חמח & $.00000 ?$ \\
\hline .50 & 0.0 & .000008 & - AnOnO? & $.000 \cap 03$ \\
\hline
\end{tabular}




\section{PLT?}

RECORD OF DAW RATA

$\begin{array}{lll}\text { TIME LOAD,LPS. } & \text { DEFLECT T ON S,IN. } \\ \text { (SEC) } \quad x=0 \quad x=3.25 \quad x=5.75 \quad x=8.25\end{array}$

\begin{tabular}{|c|c|c|c|c|}
\hline 0.00 & 0.0 & 0.000000 & $0 . \cap \cap 0000$ & 0.000000 \\
\hline - 0 ? & 0.0 & 0.000000 & $0 . \cap \cap 0000$ & 0.000000 \\
\hline .04 & 400.0 & $.000 \cap 75$ & . AnO0?4 & .000040 \\
\hline .06 & 700.0 & .000150 & - ANOARB & $.0000 R A$ \\
\hline - OA & 750.0 & .000375 & - $\triangle \cap 0>\angle A$ & .000120 \\
\hline .10 & 750.0 & .000435 & .000304 & .000174 \\
\hline .12 & 750.0 & .000442 & . $\cap \cap 0374$ & $.00012 A$ \\
\hline .14 & 750.0 & .000450 & - $\cap \cap 032 R$ & .000137 \\
\hline .16 & 750.0 & .000465 & $. \cap \cap \cap 3>9$ & .000177 \\
\hline - 1A & 750.0 & $.0004 A 0$ & - $\cap \cap 0332$ & $.00013 \pi$ \\
\hline - $P C$ & 750.0 & $.0004 A A$ & . $\cap \cap 033 x$ & .000136 \\
\hline .72 & 0.0 & .000225 & $.0 \cap 0248$ & .000000 \\
\hline .24 & 0.0 & .000105 & - nחOnR4 & .000024 \\
\hline -26 & $0 . n$ & .000075 & - & $.000 \cap 0 A$ \\
\hline .28 & 0.0 & .000060 & - & .000004 \\
\hline .30 & $0 . n$ & .000045 & . $\cap \cap \cap O \cap R$ & .000004 \\
\hline .32 & 0.0 & $.00003 A$ & . 000004 & .000004 \\
\hline .34 & 0.0 & .000030 & .000004 & $.000 \cap 04$ \\
\hline - 36 & 0.0 & .000023 & .000004 & .000004 \\
\hline - 3A & $0 . n$ & .000015 & $.0 \cap 0004$ & .000004 \\
\hline .40 & 0.0 & .000015 & .000004 & .000004 \\
\hline .47 & 0.0 & .000015 &.$\cap \cap 0 \cap 04$ & .000004 \\
\hline .44 & 0.0 & .000015 & - $n \cap 0 \cap 04$ & - 000004 \\
\hline $.4 h$ & $0 . n$ & .000015 &.$\cap 00004$ & .000004 \\
\hline .48 & 0 . $c$ & .000015 & - $\cap 00004$ & $.000 \cap n 4$ \\
\hline .50 & 10.0 & י & $\cdot 0 \pi 0004$ & .000004 \\
\hline
\end{tabular}


RESPONSE FUNCTIONS FROM IMPI TCTT CONVALITIOA

TIMF

(SEC)

\begin{abstract}
F F S P O N S F
\end{abstract}
$x=3.75$

0.000

.020

.040

.060

- naR

.100

.120

.140

.160

.180

.200

- 220

.240

- zan

- टAO

- 300

. 320

.340

.360

- 380

.400

.420

.440

.460

.480

.500
.00000050 . 00000095 - nnกnOP36 - $\cap \cap 000253$ - กnก00234 - กก000215 - $0 \cap 000203$ - กกกกก193 .00000179 - $\operatorname{~ถ\cap 000010~}$ - 00000080

-. 0n00006

- $0 \cap 000047$

- . nกnก0029

-. 00000000 - กก0ก0007 - $0 \cap \cap 000$ ? 1 - onononza - nnnח0028 - OAnO0017 - กกกDOOOR - OOกOก003 -. 00000001 -. 00000001 -. .0ก000006 - nnononor
$.000 n 0016$ - nOnOก057 - nnonciar - noonolat - ODEACITK - nonanisi . 00000145 - nOAnO13z - nOกnก12? - NOBAnOEz

- . nOAnก070

- คOONACO77

-.000ก0057

- . nחnกnOź

- . 000กnODIo

- onnOnODO - nonnno11 - nORnAOP? - noonnosa . nOnnnol - nOBnกOOA - nOCANOOO

- coconno03

-.000AnO05

- . DONOnO06

- . notinnoos
.00000027 $.000 n \cap \cap 51$ . $000 \cap 0 \cap 73$ . 0000nnar - 000000R4 . O0OBOnan $.0000 \cap 054$ . OONOORE . OODnRBAK . 0000nกñ

-. 00000026

-. $000 \cap 0 \cap>7$

-.000ก0ก>0

. 0000001 ?

-. 000000ก5 .00000001 - o00nomata . 00000010 . 00nnania . 000nanas . 0000nonz .00000001

. .000000ก

$-.00000001$

-.0000ก0ก?

$-.00000003$ 
PLI3

DEFLECTIONS FROM RFSPONSF FIINCTIONE ANR LAAT

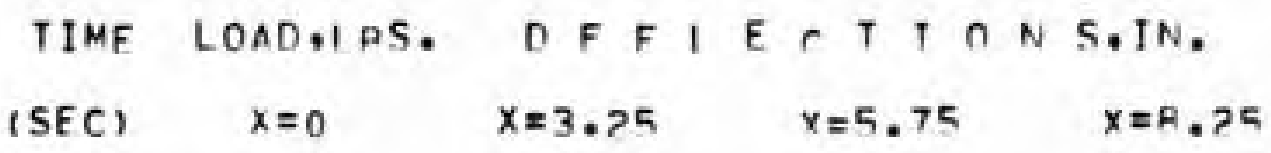

\begin{tabular}{|c|c|c|c|c|}
\hline 0.00 & 0.0 & 0.000000 & $0.0 n 0000$ & 0.000000 \\
\hline $\begin{array}{l}.02 \\
.04 \\
.06\end{array}$ & $\begin{array}{r}0.0 \\
400.0 \\
700.0\end{array}$ & $\begin{array}{r}0.000000 \\
.000075 \\
.000150\end{array}$ & 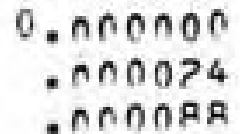 & $\begin{array}{r}0.000000 \\
.000040 \\
.000020\end{array}$ \\
\hline . $\cap 8$ & 750.0 & .000375 & . $\cap \cap \cap>\triangle A R$ & .000120 \\
\hline .10 & $750 . n$ & .000435 & .000304 & $.0001>4$ \\
\hline .12 & 750.0 & .000443 & $. \cap \cap 03>4$ & $.0001 ?$ \\
\hline .14 & 750.0 & .000450 & . คกคววR & .00013 \\
\hline .16 & $750 . n$ & .000465 & $=\cap \cap 07>8$ & .000137 \\
\hline .18 & 750.0 & .000480 &.$\cap \cap 0332$ & .000136 \\
\hline .20 & $750 . n$ & $.0004 R R$ & . ADOS3A & .00013 \\
\hline . ?? & 0.0 & .000225 & . $\cap \cap 0>48$ & $.0000 R$ \\
\hline $\begin{array}{l}.24 \\
.76\end{array}$ & $0 . n$ & $\begin{array}{l}.000105 \\
.000075\end{array}$ & $\begin{array}{l}\cap \cap \cap \cap \cap G 4 \\
: \operatorname{n\cap n} \cap>0\end{array}$ & $\begin{array}{l}.000 \cap 24 \\
.000 \cap 009\end{array}$ \\
\hline $.2 R$ & 0.0 & .000060 & . OnON12 & $.0000 \cap 4$ \\
\hline .30 & 0.0 & .000045 &.$\triangle 00008$ & .00000 \\
\hline -32 & $0 . n$ & $.00003 R$ & .000004 & .000004 \\
\hline .34 & 0.0 & .000030 & .000004 & .000008 \\
\hline$\cdot 36$ & 0.0 & $.000 \cap 23$ & $.0 \cap 0004$ & $.0000 \cap 4$ \\
\hline . 38 & $0 . n$ & .000015 & . $\cap 00004$ & .00000 \\
\hline .40 & 0.0 & .000015 & .000004 & .00000 \\
\hline .42 & 0.0 & .000015 & . $\cap \cap 0 \cap 04$ & $.000 n 0$ \\
\hline .44 & 0.0 & .000015 & - $\cap 00004$ & .00000 \\
\hline .46 & $0 . n$ & .000015 & .000004 & .000004 \\
\hline .48 & $0 . n$ & .000015 & . $\cap \cap 0 \cap 04$ & .00000 \\
\hline .50 & $0 . n$ & .000015 & .000004 & .00000 \\
\hline
\end{tabular}


2MT

RECORD OF RAW DATA

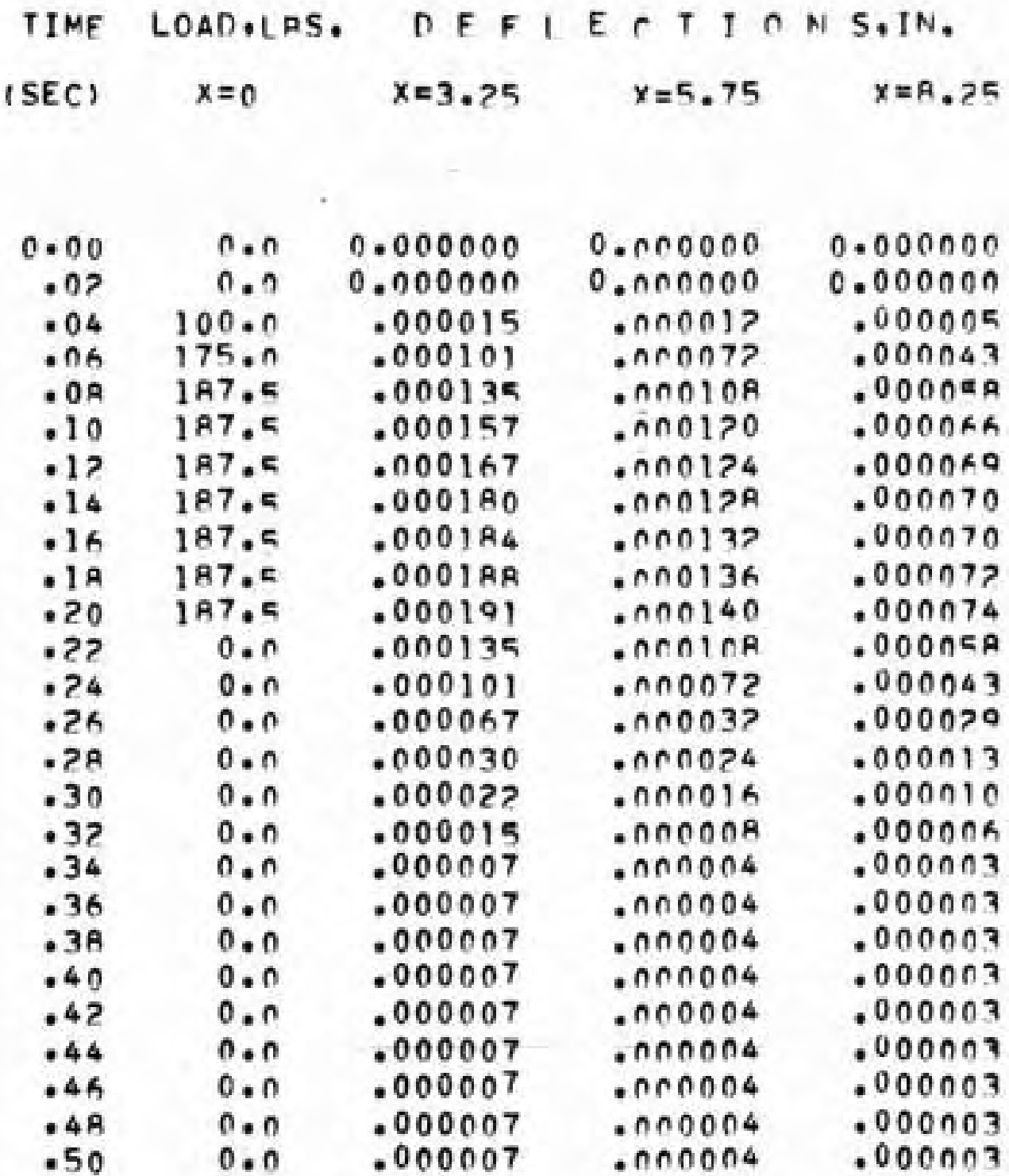




\section{MI 1}

RESPONSE FUNCTIONS FROM IMPITCIT CONVOLIITION

TIME RESPONSF FUNCTIONS (SEC) $x=3.25$ $x=5,75$ $x=8.25$

\begin{tabular}{|c|c|c|c|}
\hline $\begin{array}{l}0.000 \\
.020 \\
.040 \\
.060\end{array}$ & $\begin{array}{l}.00000040 \\
.0 \cap 000766 \\
.0 \cap 000331 \\
\text {. OnO00358 }\end{array}$ & $\begin{array}{l}.00000032 \\
.00000189 \\
.00000267 \\
.00000273\end{array}$ & $\begin{array}{l}.00000013 \\
.00000114 \\
.00000142 \\
.00000149\end{array}$ \\
\hline $\begin{array}{l}.080 \\
.100 \\
.120\end{array}$ & 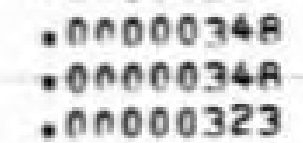 & $\begin{array}{l}.000 n \cap 256 \\
.000 n 0241 \\
.00000228\end{array}$ & $\begin{array}{l}.00000143 \\
.00000133 \\
.00000119\end{array}$ \\
\hline $\begin{array}{l}.140 \\
.180 \\
.180 \\
.200\end{array}$ & $\begin{array}{l}\text { OONON0301 } \\
\text { •ONODOP81 } \\
\text { ONOONO106 } \\
\text { OONODO031 }\end{array}$ & $\begin{array}{l}.00000216 \\
.00000205 \\
.000 N 0102 \\
.00000014\end{array}$ & $\begin{array}{l}.00000112 \\
.00000105 \\
.00000053 \\
.00000070\end{array}$ \\
\hline $\begin{array}{l}.220 \\
.240\end{array}$ & $\begin{array}{l}=00000029 \\
=00000091 \\
=000000068\end{array}$ & $\begin{array}{l}=0000006 A \\
=000 N 0056 \\
=\end{array}$ & $\begin{array}{l}=000000006 \\
\because 00000034 \\
\because 00000025\end{array}$ \\
\hline $\begin{array}{r}.280 \\
.300\end{array}$ & $\begin{array}{l}=00000046 \\
\because 00000029\end{array}$ & $\begin{array}{l}=00000038 \\
\because 00000027\end{array}$ & $\begin{array}{l}-000000017 \\
\because 00000012\end{array}$ \\
\hline $\begin{array}{r}.320 \\
.340 \\
.360 \\
.380 \\
.400\end{array}$ & $\begin{array}{l}.00000004 \\
.00000032 \\
.00000040 \\
.00000039 \\
.00000032\end{array}$ & $\begin{array}{l}.00000002 \\
.00000022 \\
.00000030 \\
.00000029 \\
.000 n 0019\end{array}$ & $\begin{array}{l}.00000000 \\
.00000011 \\
.00000015 \\
.00000016 \\
.00000013\end{array}$ \\
\hline $\begin{array}{l}.420 \\
.440 \\
.460 \\
.480 \\
.500\end{array}$ & $\begin{array}{r}.00000020 \\
.00000011 \\
.00000005 \\
=00000008 \\
=000000017\end{array}$ & $\begin{array}{r}.00000011 \\
.00000006 \\
.000000001 \\
-.00000007 \\
-.00000011\end{array}$ & $\begin{array}{r}.00000009 \\
.00000005 \\
.00000003 \\
-.00000003 \\
-.00000007\end{array}$ \\
\hline
\end{tabular}


>MT 1

DFFLECTIONS FROM RFSPONSF FIIRCTTONG $\triangle N$ I OAN

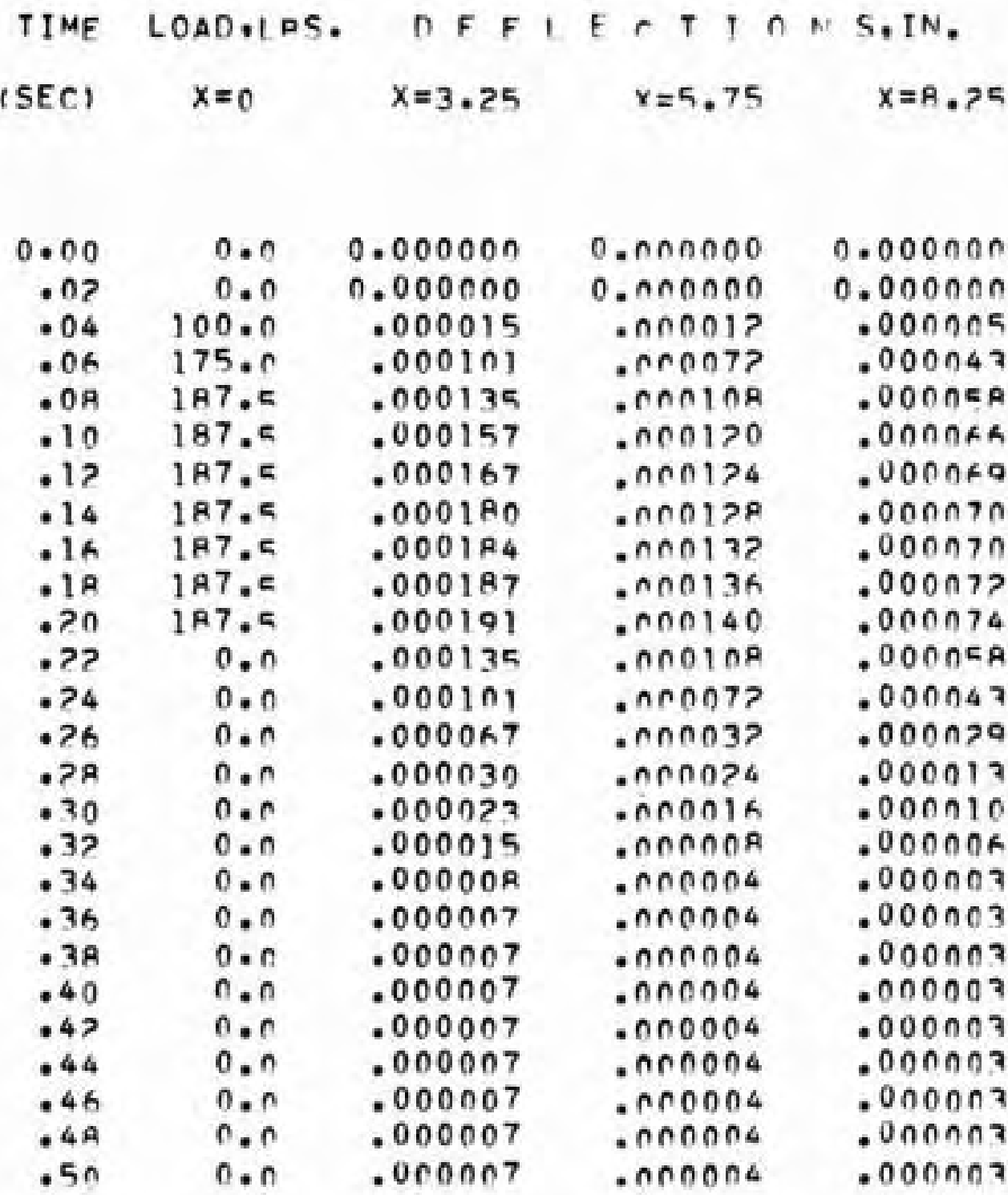


PMT?

RECORN OF DAW DATA

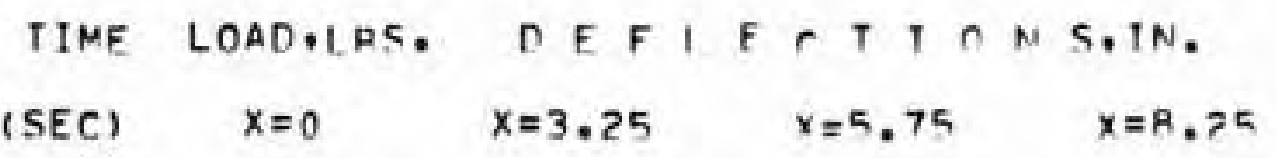

\begin{tabular}{|c|c|c|c|c|}
\hline $\begin{array}{r}0.00 \\
.02\end{array}$ & $\begin{array}{l}0.0 \\
0.0\end{array}$ & $\begin{array}{l}0.000000 \\
0.000000\end{array}$ & $\begin{array}{l}0 . \cap \cap 0 \cap 00 \\
0 . \cap \cap D O 00\end{array}$ & $\begin{array}{l}0.000000 \\
0.000000\end{array}$ \\
\hline $\begin{array}{l}.04 \\
.06\end{array}$ & $\begin{array}{l}200.0 \\
350.0\end{array}$ & $\begin{array}{l}.000015 \\
.000135\end{array}$ & 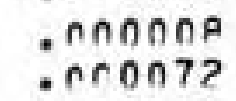 & $\begin{array}{l}.000 \cap \cap 0 \\
.000 \cap 7 ?\end{array}$ \\
\hline $\begin{array}{l}.08 \\
.10\end{array}$ & $\begin{array}{l}375 \cdot n \\
375 * 0\end{array}$ & $\begin{array}{l}.000703 \\
.000770\end{array}$ & 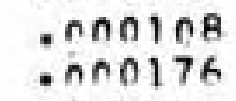 & $\begin{array}{l}.0001 \cap 0 \\
.0001 \geqslant 4\end{array}$ \\
\hline .12 & $375 . n$ & .000330 & - ACOPIT & .00012 ? \\
\hline .14 & $375 . n$ & .000345 & $.000>48$ & .000134 \\
\hline .16 & $375 . n$ & .000360 & - $\cap \cap \cap P 6 A$ & .000140 \\
\hline . 19 & 375.0 & .000367 & . AnCP7? & .000144 \\
\hline .20 & 375.0 & .000375 & - ANOP7K & .000144 \\
\hline .77 & 0.0 & .000770 & . 000176 & .000108 \\
\hline .24 & 0.0 & .000177 & . AAC10R & . \\
\hline .26 & 0.0 & .000135 & . 01007 ? & ב3000 \\
\hline .28 & 0.0 & .000060 & - $\cap \cap 0 \cap 37$ & $.000 n>4$ \\
\hline .30 & $0 . n$ & .000045 & . $\cap 000>4$ & .000016 \\
\hline .32 & 0.0 & $.000 \cap 3 n$ & . & $.000 \cap 0$ A \\
\hline .74 & 0.0 & .000015 &.$A \cap O O D A$ & $.000 \cap 04$ \\
\hline .36 & $0 . n$ & .000015 & - $\cap \cap O \cap \cap R$ & .000004 \\
\hline $.3 B$ & 0.0 & .000015 & - APOOOR & .000004 \\
\hline .40 & 0.0 & .000015 & - ACOADR & $.000 \cap \cap 4$ \\
\hline .47 & $0 . n$ & .000015 & - CAOBOA & $.000 \cap \cap 4$ \\
\hline .44 & $0 . n$ & .000015 & . $\cap \cap \cap \cap \cap R$ & .000008 \\
\hline .46 & 0.0 & .000015 & - AnOOOR & .000004 \\
\hline $.4 A$ & 0.0 & .000015 & . $\cap \cap O \cap \cap R$ & $.000 \cap 04$ \\
\hline .50 & 0.0 & .000015 & . $\cap \cap \cap O O A$ & .000004 \\
\hline
\end{tabular}


2M+?

RESPONSE FUNCTIONS FROM TMPI TCTT CONYOIITIOA

TIME DESPOASF FUNCTIONS

(SEC) $\quad x=3.25 \quad x=5.75 \quad x=8.25$

\begin{tabular}{|c|c|c|c|}
\hline $\begin{array}{r}.000 \\
.020\end{array}$ & $\begin{array}{l}-00000020 \\
00000178\end{array}$ & - $00 \cap A \cap 011$ & $\begin{array}{l}.00000011 \\
0,0000005\end{array}$ \\
\hline .020 & .00000178 & & \\
\hline $\begin{array}{l}.040 \\
.060\end{array}$ & $\begin{array}{l}\cdot 0 n n 00251 \\
\text { - OAnמO0317 }\end{array}$ & 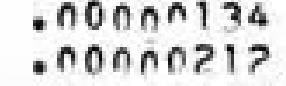 & $\begin{array}{l}.0000 \cap 124 \\
.0000 \cap 14 ?\end{array}$ \\
\hline .080 & - $0 \cap 000365$ & - $\cap \cap \cap A \cap 230$ & $.0000 n 139$ \\
\hline .100 & $.0 n 000349$ & $.0000 C 262$ & חדובות \\
\hline .120 & . 00000334 & - $\cap \cap \cap \cap \cap P A 4$ & $.000001>?$ \\
\hline .140 & $.0 \cap 000311$ & - $00 \cap \cap \cap 243$ & .00000115 \\
\hline-160 & .00000289 & - nOnñC2? & $.000 \cap \cap 1 \cap 4$ \\
\hline .190 & - $n \cap n \cap 0122$ & - $\operatorname{AnnOCOOGO}$ & . $0000 \cap 04 \mathrm{~K}$ \\
\hline .700 & $=.00000003$ & - $A \cap A \cap C O P O$ & .00000003 \\
\hline - 220 & $=.00000029$ & - $\operatorname{CAnA\cap 053}$ & $=.00 \cap \cap \cap \cap \neg R$ \\
\hline .240 & $=.00000094$ & $=. \cap 0 \cap \cap \cap 0 A 0$ & $-.00000 \cap 71$ \\
\hline .260 & - 00000069 & $=.00 \cap 00050$ & $-.00 \cap n \cap n>4$ \\
\hline - ?Aก & - $\cap \cap n 000047$ &.$- \cap 0 \cap \cap \cap \cap 3 R$ & $=.00000019$ \\
\hline .300 & $=.00000028$ & $=. \cap \cap 0 \cap \cap 01 R$ & ו וחחח חח . \\
\hline $.3>0$ & .00000006 & - AOOAOOOA & $.000 \cap \cap \cap \cap ?$ \\
\hline $\begin{array}{l}.340 \\
.360\end{array}$ & $\begin{array}{l}.00000034 \\
.00000043\end{array}$ & 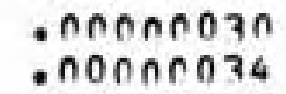 & $\begin{array}{l}.00000 \cap 1 \% \\
.0000001 A\end{array}$ \\
\hline . 380 & .00000039 & - $000 \cap 00>9$ & .00000015 \\
\hline .400 & .00000032 & - $\cap \cap \cap \cap \cap 0>0$ & $.000000 \cap 0$ \\
\hline $.4>0$ & .00000019 & . $000 n 0010$ & $.0000 \cap 0 \cap 5$ \\
\hline .440 & .00000010 & - 00000003 & $.000 \cap 00 \cap ?$ \\
\hline .460 & - 00000005 & $=.00000001$ & .00000000 \\
\hline .490 & $=.00000009$ & $-.0 \cap 0 \cap 000 R$ & $-.000 \cap \cap \cap 04$ \\
\hline .500 & -.00000017 & $\because 0000001 ?$ & $-.000 \cap 0 \cap 0 x$ \\
\hline
\end{tabular}


PMT?

DEFLECTIONS FROM RESPONSF FIINCTIONS ANA I OAN

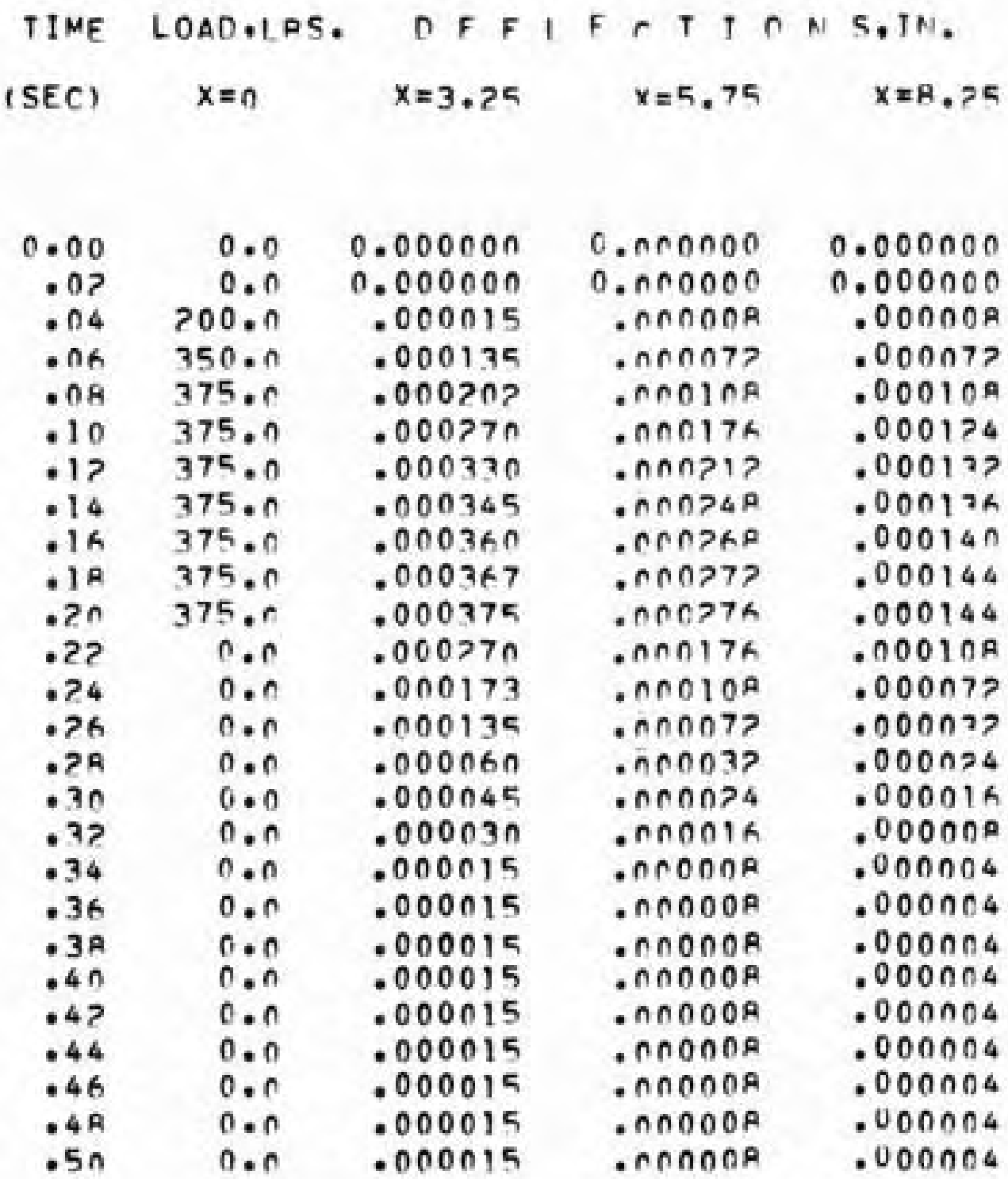




\section{PMI 7}

RECORN OF PAW NATA

TIME LOAN,LRS. $D E F L E C T, \cap N S, I N$.
(SEC) $\quad x=0 \quad x=3.25 \quad x=5.75 \quad x=8.75$

\begin{tabular}{|c|c|c|c|c|}
\hline 0.00 & 0.0 & 0.000000 & $0 . \cap \cap \cap \cap 00$ & $0.000 \cap 00$ \\
\hline ० 0? & 0.0 & 0.000000 & ก. $\cap \cap 0 \cap 00$ & $0.000 \cap \cap \cap$ \\
\hline $\begin{array}{l}.04 \\
.06\end{array}$ & $\begin{array}{l}400 \cdot n \\
700 \cdot 0\end{array}$ & $\begin{array}{l}.000090 \\
.000675\end{array}$ & $\begin{array}{l}\text { InOOORO } \\
\text { OnNO437 }\end{array}$ & $\begin{array}{l}.000 \cap 40 \\
.000>0 A\end{array}$ \\
\hline $.0 A$ & 750.0 & .000750 & - $\cap \cap \cap 477$ & .000279 \\
\hline .10 & 750.0 & .000780 & $.0 \cap 04 R 0$ & $.00023 ?$ \\
\hline .17 & 750.0 & .000810 & . $\cap \cap 04 R A$ & .000276 \\
\hline .14 & 750.0 & .000817 & - nnOLAR & $.000>40$ \\
\hline .16 & 750.0 & .000825 &.$n \cap 0496$ & .000744 \\
\hline .18 & 750.0 & $.000 R 32$ & . $\cap \cap 0504$ & $.000>49$ \\
\hline .20 & $750 . n$ & .000840 & . An051? & $.00075 ?$ \\
\hline .?? & $0 . n$ & .000600 &. $\operatorname{nn03} 30$ & $.0001<n$ \\
\hline .24 & $C .0$ & .000300 & $. O \cap \cap>0 R$ & .000000 \\
\hline .26 & 0.0 & $.00015 n$ & .000160 & .000040 \\
\hline .28 & 0.0 & .000075 & . $\cap 000 R 0$ & .000037 \\
\hline - 30 & 0.0 & .000060 & . $\cap \cap 004 R$ & $.000 n>4$ \\
\hline .32 & 0.0 & .000045 & .000032 & .000016 \\
\hline - 34 & 0.0 & .000030 & - $n \cap 0024$ & .00000 A \\
\hline .36 & 0.0 & .000015 & .000016 & .000004 \\
\hline .38 & 0.0 & .000015 & . $\cap D \cap O D R$ & .000004 \\
\hline .40 & 0.0 & .000015 & . $\cap \cap O \cap \cap A$ & .000004 \\
\hline .42 & 0.0 & .000015 & . $\cap 0 O D O R$ & .000004 \\
\hline .44 & 0.0 & .000015 & . $\cap \cap 0 \cap 0 R$ & .000004 \\
\hline .46 & $0 . n$ & .000015 & - $\cap \cap \cap O \cap R$ & $.000 \cap 04$ \\
\hline $.4 A$ & $0 . n$ & .000015 &.$\cap \cap O O \cap A$ & .000004 \\
\hline .50 & $0 . n$ & .000015 & - $\cap \cap O O \cap A$ & .000004 \\
\hline
\end{tabular}


RESPONSE FUNCTIONS FROM IMPI TCIT CONVOLITIOA

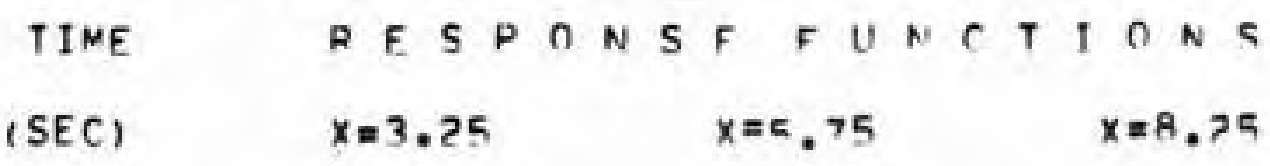

\begin{tabular}{|c|c|c|c|}
\hline $\begin{array}{r}0.000 \\
.020\end{array}$ & $\begin{array}{l}.0 \cap 000060 \\
.0 \cap 000444\end{array}$ & $\begin{array}{l}\text { - } 00 \cap 0 \cap \cap 053 \\
\text { - DOAnORZZ3 }\end{array}$ & $\begin{array}{l}.00000077 \\
.00000171\end{array}$ \\
\hline .040 & .00000453 & - $\cap 00 \cap C P R 3$ & .00000137 \\
\hline .060 & .00000427 & - $\cap \cap \cap \cap \cap P 60$ & $.000001>A$ \\
\hline $.0 A 0$ & . $\cap 0000404$ & . ก ก0กค?30 & .00000116 \\
\hline .100 & .01000369 & - ก0กคก?? & .00000107 \\
\hline .120 & .00000337 & . & .00000009 \\
\hline .140 & .00000308 & $.000 \cap \cap 184$ & .00000092 \\
\hline $.16 n$ & .00010282 & . $\cap 0 \cap \cap \cap 170$ & $.000 \cap 0 \cap 85$ \\
\hline - 18n & .00000099 & .00000031 & $.0000001 A$ \\
\hline .200 & -.00000067 & $-.00 \cap n C O P O$ & -.00000025 \\
\hline . २२० & $=.0 \cap n 000116$ & 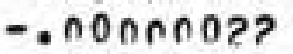 & $=.00000035$ \\
\hline .240 & -.00000112 & $\because .000 \cap 0047$ & $-.000000>5$ \\
\hline $.2 \mathrm{kO}$ & -.00000071 & $=. \cap 0 \cap \cap \cap 040$ & $-.0000001 A$ \\
\hline -280 & $=.00000036$ & -. $\cap A \cap \cap \cap \cap 0 ? 4$ & $-.000 \cap 0 \cap 09$ \\
\hline .300 & $\because .00000009$ & $-.000 \cap 0007$ & -.00000003 \\
\hline .320 & .00000013 & - $0 \cap 0 \cap 0006$ & .00000004 \\
\hline $\begin{array}{l}.340 \\
.360\end{array}$ & $\begin{array}{l}.0 \cap 000040 \\
.0 \cap 000046\end{array}$ & 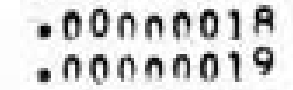 & $\begin{array}{l}.0000001 ? \\
.0000001 ?\end{array}$ \\
\hline . 390 & . 00000035 & - OOCOODOTE & .00000009 \\
\hline .400 & .00000020 & .00000011 & .00000004 \\
\hline $.4>0$ & .00000006 & .00000006 & .00000001 \\
\hline .440 & $=.00000001$ & - AnODOOOO1 & -.00000000 \\
\hline .460 & -.00000005 & - ONONnO00? & -.00000001 \\
\hline $.4 \mathrm{RO}$ & $=.00000010$ & -.00000005 & -.00000003 \\
\hline .500 & $=.00000013$ & . OAOAOAOA & $-.000 \cap n \cap n 3$ \\
\hline
\end{tabular}


DEFLECTIONS FROM RESPONSF FIINCTIONG ANO LOAN

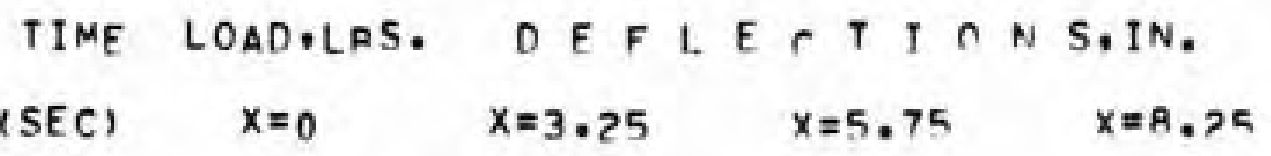

\begin{tabular}{|c|c|c|c|c|}
\hline $\begin{array}{r}0.00 \\
.02\end{array}$ & $\begin{array}{l}0.0 \\
0.0\end{array}$ & $\begin{array}{l}0.000000 \\
0.000000\end{array}$ & $\begin{array}{l}0.000000 \\
0.000000\end{array}$ & $\begin{array}{l}0.000000 \\
0.000000\end{array}$ \\
\hline .04 & 400.0 & .000090 & . $\cap O O O B O$ & .000040 \\
\hline .06 & 700.0 & .000675 &.$\cap \cap 0432$ & .000200 \\
\hline . OR & 750.0 & .000750 & . $\cap \cap 0472$ & $.000>28$ \\
\hline $\begin{array}{l}.10 \\
.12\end{array}$ & $\begin{array}{l}750.0 \\
750.0\end{array}$ & $\begin{array}{l}.000780 \\
.000810\end{array}$ & - $\cap \cap 0 \angle R O$ & $\begin{array}{l}.000237 \\
.000236\end{array}$ \\
\hline .14 & 750.0 & .000817 & .000496 & $.000>00$ \\
\hline .16 & 750.0 & .000825 &. $\operatorname{In} 0496$ & $.000>44$ \\
\hline .18 & 750.0 & .000837 & .000504 & $.000>4 R$ \\
\hline .20 & $750 . n$ & .000840 & . nח051? & $.00025 ?$ \\
\hline .22 & 0.0 & .000600 & $. \cap \cap \cap 3>0$ & $.0001 \in n$ \\
\hline .24 & 0.0 & .000300 & . $O \cap 0 ? \cap \cap B$ & .000000 \\
\hline .26 & $0 . n$ & .000150 & 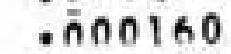 & .000040 \\
\hline . $2 R$ & 0.0 & .000075 & . ANOORO & קיחס000 \\
\hline .30 & 0.0 & $.00006 n$ & .000048 & $.0000>4$ \\
\hline . 32 & 0.0 & .000045 & .010032 & 00016 \\
\hline .34 & 0.0 & .000030 & - $\cap \cap 0 \cap>4$ & $.000 \cap 0 A$ \\
\hline$\cdot 36$ & 0.0 & .000015 & $.0 n 0016$ & .000004 \\
\hline .38 & 0.0 & .000015 & . AODOOOR & .000004 \\
\hline .40 & $0 . n$ & .000015 & $.00000 A$ & .000004 \\
\hline $.4 ?$ & 0.0 & .000015 & $.00000 R$ & .000004 \\
\hline .44 & 0.0 & .000015 & - $\cap \cap 000 A$ & .000004 \\
\hline .46 & 0.0 & .000015 & $.00000 R$ & .000004 \\
\hline .48 & 0.0 & .000015 & . $D 00008$ & .000004 \\
\hline .50 & $0 . n$ & .000015 & - OOOOOA & .000004 \\
\hline
\end{tabular}


2HT

RECORD OF DAW DATA

TIME LOAD,LAS. DEFLECTI $\cap N S, I N$.
(SEC) $x=0 \quad x=3.25 \quad x=5.75 \quad x=8.2=$

\begin{tabular}{|c|c|c|c|c|}
\hline $\begin{array}{r}0.00 \\
.02\end{array}$ & $\begin{array}{l}0.0 \\
0.0\end{array}$ & $\begin{array}{l}0.000000 \\
0.000000\end{array}$ & $\begin{array}{l}0.000000 \\
0.000000\end{array}$ & $\begin{array}{l}0.000000 \\
0.000000\end{array}$ \\
\hline .04 & $\begin{array}{l}100.0 \\
175.0\end{array}$ & $\begin{array}{l}.000060 \\
.000225\end{array}$ & $\begin{array}{l}\text { ONOOOB? } \\
\text { OANOARO }\end{array}$ & $\begin{array}{l}.000016 \\
.000037\end{array}$ \\
\hline .OA & 187.5 & $.00024 n$ & - חDOOIAO & $\begin{array}{l}.0000 E R \\
.000090\end{array}$ \\
\hline $\begin{array}{l}.10 \\
.12\end{array}$ & $\begin{array}{l}187.5 \\
187.5\end{array}$ & .000255 & - $\cap \cap 0208$ & .000096 \\
\hline .14 & 187.5 & .000285 & . OAOPIR & .000100 \\
\hline .16 & 187.5 & .000300 & . $\cap n 0 ? ? 4$ & .000104 \\
\hline - 1A & 187.5 & .000315 & - $\cap \cap 0232$ & .000108 \\
\hline .20 & 187.5 & .000330 & 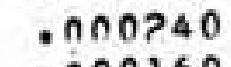 & $.00011 ?$ \\
\hline .2? & $0 . n$ & .000150 & .000160 & .000020 \\
\hline .24 & 0.0 & $.0001>0$ & - AnOARO & .000040 \\
\hline .26 & 0.0 & .000090 & .000064 & .000037 \\
\hline . $2 A$ & 0.0 & .000060 &.$\cap 00 \cap 4 R$ & $.0000>4$ \\
\hline$\cdot 30$ & $0 . n$ & .000045 & - $\cap \cap 0 \cap 3 ?$ & .000016 \\
\hline .32 & 0.0 & .000030 & $.0 \cap 0024$ & $.00001 ?$ \\
\hline $\begin{array}{r}.34 \\
.36\end{array}$ & $\begin{array}{l}0.0 \\
0.0\end{array}$ & $\begin{array}{l}.000015 \\
.000015\end{array}$ & 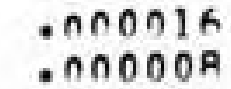 & $\begin{array}{l}.00000 A \\
.000004\end{array}$ \\
\hline $\begin{array}{l}.38 \\
.40\end{array}$ & 0.0 & $\begin{array}{l}.000015 \\
.000015\end{array}$ & $\begin{array}{l}-\cap \cap 0 O O R \\
. \cap \cap O O O A\end{array}$ & $\begin{array}{l}.000004 \\
.000004\end{array}$ \\
\hline $.4 ?$ & 0.0 & .000015 & - $\cap \cap O \cap O A$ & .000004 \\
\hline .44 & 0.0 & .000015 & . $\cap \cap 0008$ & .000004 \\
\hline .46 & 0.0 & .000015 & - $\cap \cap O \cap \cap A$ & .000004 \\
\hline .48 & 0.0 & .000015 & . $\cap \cap 000 R$ & .000004 \\
\hline .50 & 0.0 & .000015 & - $\cap \cap O \cap O R$ & .000004 \\
\hline
\end{tabular}


2HI 1

RESPONSE FUNCTICNS FROM IMPI TCIT CONVOLIITIOA

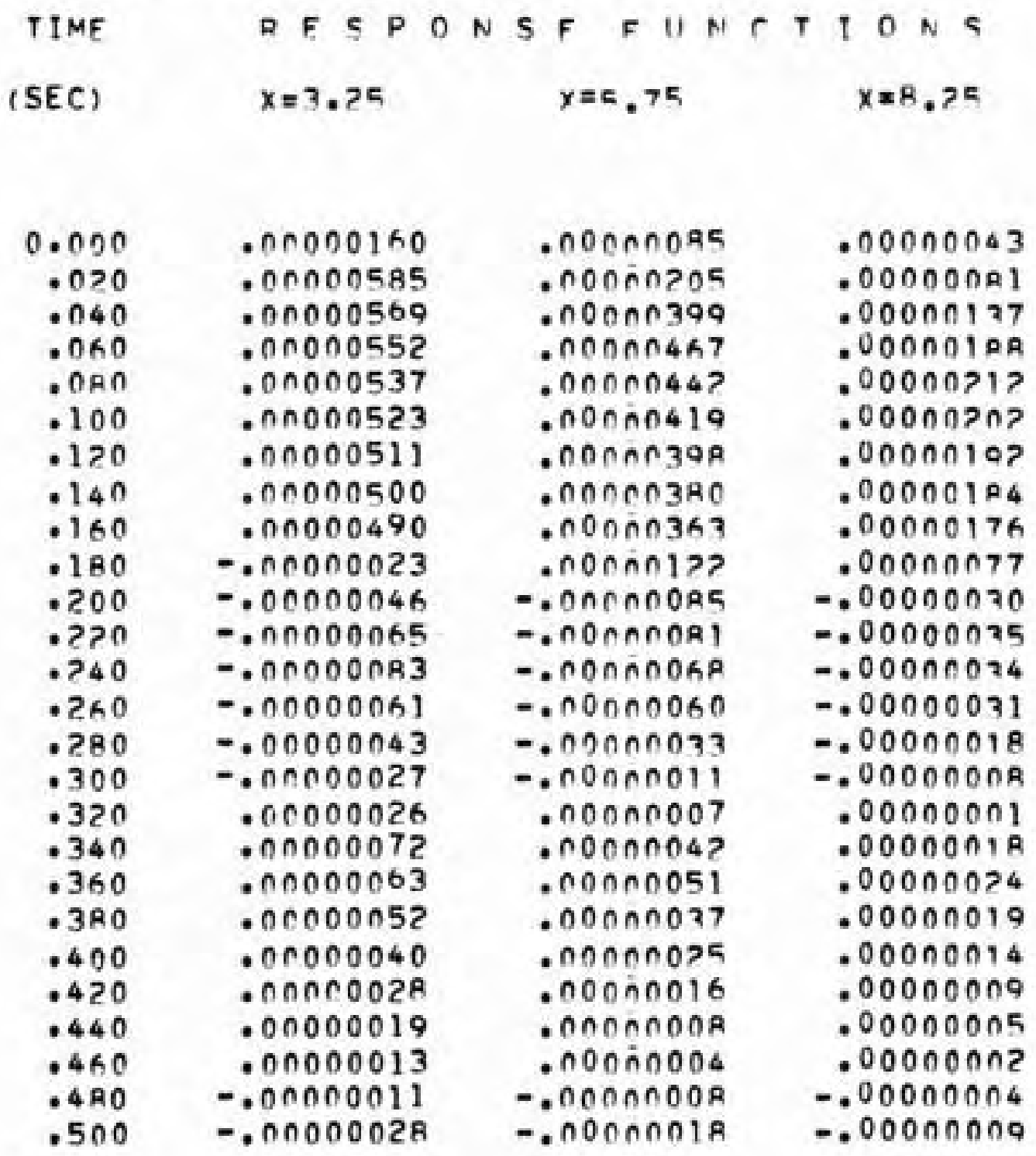


?HTI

DEFLECTIONS FRCM RESPONSF FIINCTIONS ANR IOAN

TIME LOAD,LPS.

DEF

E

(SEC)

$x=0$

$x=3 . ? 5$

$x=5.75$

$x=8.25$

\begin{tabular}{|c|c|c|c|c|}
\hline $\begin{array}{r}0.00 \\
.02\end{array}$ & $\begin{array}{l}0.0 \\
0.0\end{array}$ & $\begin{array}{l}0.000000 \\
0.000000\end{array}$ & $\begin{array}{l}0 . \cap 00000 \\
0 . A \cap 0 \cap 00\end{array}$ & $\begin{array}{l}0.000000 \\
0.000000\end{array}$ \\
\hline $\begin{array}{l}.04 \\
.06\end{array}$ & $\begin{array}{l}100.0 \\
175.0\end{array}$ & $\begin{array}{l}.00006 n \\
.000225\end{array}$ & $\begin{array}{l}. \cap 00072 \\
. \cap 00080\end{array}$ & $\begin{array}{l}.000011 \\
.000037\end{array}$ \\
\hline $\begin{array}{l}.08 \\
.10\end{array}$ & $\begin{array}{l}187.5 \\
187.5\end{array}$ & $\begin{array}{l}.000240 \\
.000255\end{array}$ & $\begin{array}{l}-\cap 00160 \\
-\cap \cap \cap P C 0\end{array}$ & $\begin{array}{l}.000056 \\
.000090\end{array}$ \\
\hline .12 & 187.5 & $.000>70$ & . $\cap \cap 0 P 0 P$ & .000096 \\
\hline .14 & $\begin{array}{l}187.5 \\
187.5\end{array}$ & $\begin{array}{l}.000285 \\
.000300\end{array}$ & $\begin{array}{l}\text { - } \cap \cap 0 P 1 R \\
\text { - } \cap \cap 0>P \angle\end{array}$ & $\begin{array}{l}.000100 \\
.000104\end{array}$ \\
\hline $\begin{array}{l}.12 \\
.20 \\
.22\end{array}$ & $\begin{array}{r}187.5 \\
187.5 \\
0.0\end{array}$ & $\begin{array}{l}.000315 \\
.000330 \\
.000150\end{array}$ & $\begin{array}{l}\cdot \cap \cap \cap 232 \\
\cdot \cap \cap 0240 \\
\cdot \cap \cap 0140\end{array}$ & $\begin{array}{l}.000109 \\
.00011 ? \\
.000000\end{array}$ \\
\hline .24 & 0.0 & .000120 & - AODOAR & .000040 \\
\hline $\begin{array}{r}.26 \\
.78\end{array}$ & 0.0 & .000090 & - InOORA & .000032 \\
\hline $\begin{array}{r}.30 \\
.32\end{array}$ & $\begin{array}{ll}0.0 \\
0.0\end{array}$ & $\begin{array}{l}.000045 \\
.000030\end{array}$ & $\begin{array}{l}\text { - } \cap \cap \cap \cap 3 ? \\
\text { - กก } 0 \text { की }\end{array}$ & $\begin{array}{l}.000016 \\
.000012\end{array}$ \\
\hline .34 & 0.0 & .000015 & . AnOOOIR & $.00 \cap \cap \cap A$ \\
\hline .36 & $0 . n$ & .000015 &.$\cap O O \cap O A$ & .000004 \\
\hline - 38 & $0 . n$ & .000015 & - $\cap \cap \cap O \cap A$ & .000004 \\
\hline $\begin{array}{l}.40 \\
.42\end{array}$ & $\begin{array}{l}0.0 \\
0.0\end{array}$ & $\begin{array}{l}.000015 \\
.000015\end{array}$ & $\begin{array}{l}-\cap \cap O O O R \\
. \triangle \cap O O \cap R\end{array}$ & $\begin{array}{l}.000004 \\
.000004\end{array}$ \\
\hline $\begin{array}{l}.44 \\
.46\end{array}$ & $\begin{array}{l}0.0 \\
0.0\end{array}$ & $\begin{array}{l}.000015 \\
.000015\end{array}$ & $\begin{array}{l}-\cap \cap O O O A \\
. \cap \cap O D O A\end{array}$ & $\begin{array}{l}.000004 \\
.000004\end{array}$ \\
\hline $.4 A$ & 0.0 & .000015 & - $\cap \cap O \cap O R$ & .000004 \\
\hline .50 & $0 . n$ & .000015 & - ODOOOA & .000004 \\
\hline
\end{tabular}




\section{HT?}

RECORT OF DAW NATA

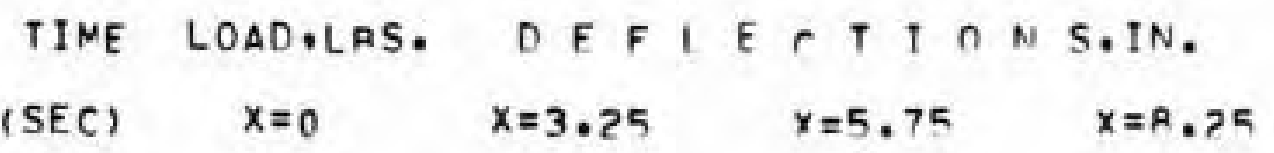

\begin{tabular}{|c|c|c|c|c|}
\hline $\begin{array}{r}0.00 \\
.02\end{array}$ & $\begin{array}{l}0.0 \\
0.0\end{array}$ & $\begin{array}{l}0.000000 \\
0.000000\end{array}$ & $\begin{array}{l}0 . \cap \cap 0000 \\
0 . \cap \cap 00000\end{array}$ & $\begin{array}{l}0.000000 \\
0.000000\end{array}$ \\
\hline .04 & $\begin{array}{l}200.0 \\
350.0\end{array}$ & $\begin{array}{l}.000120 \\
.000480\end{array}$ & $\begin{array}{l}\text { :nnO0O64 } \\
\text { OnnO144 }\end{array}$ & .000040 \\
\hline - $0 \Omega$ & 375.0 & .000600 & . $\cap 0027 ?$ & .000162 \\
\hline .10 & $375 . n$ & .000615 & . $01035 ?$ & .000197 \\
\hline $\begin{array}{l}.12 \\
.14\end{array}$ & $\begin{array}{l}375.0 \\
375.0\end{array}$ & $\begin{array}{l}.000630 \\
.000645\end{array}$ & $\begin{array}{l}\cap \cap 0437 \\
. \cap \cap 0448\end{array}$ & $\begin{array}{l}.00020 R \\
.00021 ?\end{array}$ \\
\hline .16 & $\begin{array}{l}375 . n \\
375 . n\end{array}$ & $\begin{array}{l}.000660 \\
.000675\end{array}$ & $\begin{array}{l}n \cap 00464 \\
. \cap n 0477\end{array}$ & $\begin{array}{l}.000>1 \% \\
.000>>00\end{array}$ \\
\hline .20 & 375.0 & $.00060 n$ &.$\cap \cap 04 R 0$ & .000274 \\
\hline .22 & 0.0 & $.00033 n$ &.$\cap \cap 035 ?$ & $.00017 k$ \\
\hline .24 & 0.0 & .000210 &.$\cap \cap 027 ?$ & .000136 \\
\hline .26 & 0.0 & .000180 & . AnO19? & $.000 \cap 96$ \\
\hline .28 & 0.0 & .000150 & - nnO011? & $.0000 \times 4$ \\
\hline .30 & 0.0 & .000120 & .000080 & .000048 \\
\hline . 32 & 0.0 & .000090 & $.0 \cap 0064$ & .000037 \\
\hline .34 & 0.0 & .000075 &.$\cap \cap 0 \cap 48$ & $.0000>8$ \\
\hline .36 & 0.0 & .000060 &.$\cap \cap 0 \cap 40$ & $.000 \cap>24$ \\
\hline - 3A & 0.0 & .000045 &. $\operatorname{nnOn3?}$ & $.0000>0$ \\
\hline $.4 n$ & $0 \cdot n$ & .000030 & - $\cap n O O ? 4$ & - $00001 \mathrm{~A}$ \\
\hline .42 & 0.0 & .000015 &.$\cap \cap 0016$ & .000012 \\
\hline $\begin{array}{l}.44 \\
.46\end{array}$ & $\begin{array}{l}0 . n \\
0 . n\end{array}$ & $\begin{array}{l}.000015 \\
.000015\end{array}$ & $\begin{array}{l}\text { - } \cap \cap \cap \cap O R \\
\text { - } \cap \cap O \cap O R\end{array}$ & $\begin{array}{l}.000008 \\
.000004\end{array}$ \\
\hline $.4 R$ & 0.0 & .000015 & - $00000 R$ & .000004 \\
\hline .50 & 0.0 & .000015 & - ACOOOR & .000004 \\
\hline
\end{tabular}


२HT?

RESPONSE FUNCTIONS FROM INPI TCIT CONVOLUTION

TIME RESPONSFFUNCTIONS

(SEC) $\quad x=3.25 \quad x=5.75 \quad x=8.25$

\begin{tabular}{|c|c|c|c|}
\hline 0.000 & .00000160 & - OONOOORE & $.000000<3$ \\
\hline .020 & .00000625 & . $00 \cap \cap 01 A_{4}$ & $.0000017 \pi$ \\
\hline $\begin{array}{l}.040 \\
.060\end{array}$ & $\begin{array}{l}\text { - } \cap \cap 00072 A \\
\text { - } \cap \cap 000674\end{array}$ & $\begin{array}{l}\text { - } \cap \cap \cap \cap \cap 337 \\
\text {. } \cap 0 \cap \cap \cap 411\end{array}$ & $\begin{array}{l}.00000 ? n ? \\
.0000 \cap ? 14\end{array}$ \\
\hline .0A0 & .00000626 & $.000 \cap 0477$ & $.00000>14$ \\
\hline .100 & .00000583 & $.000 \cap 0451$ & .00000108 \\
\hline$-1>0$ & .00000545 & - $000 \cap 0427$ & .00000183 \\
\hline .140 & - $0 \cap 000510$ & - $000 \cap 0395$ & .00000170 \\
\hline .160 & .00000479 & - ODORAOBAG & $.000 \cap 01=0$ \\
\hline .180 & $=.000000 \mathrm{J3}$ & - $20 n n n 167$ & .00000084 \\
\hline .200 & -.00000131 & $.000 \cap 0061$ & .00000039 \\
\hline$\bullet>>0$ & $\because 00000086$ & $=00000019$ & $.00000 \cap 0 ?$ \\
\hline .240 & $=.00000050$ & 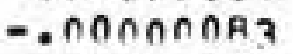 & $-.000000>0$ \\
\hline .260 & $=.00000022$ & $-.00 \cap \cap \cap \cap 70$ & -.00000018 \\
\hline $\begin{array}{l}-380 \\
3000\end{array}$ & $\begin{array}{r}-.00000001 \\
.00000033\end{array}$ & $=000 n \cap 00>0$ & $\begin{array}{l}-00000017 \\
\because 00000003\end{array}$ \\
\hline .320 & .00000061 & .00000016 & .00000009 \\
\hline .340 & .00000083 & - $O O \cap n \cap O 41$ & $.000 n 0010$ \\
\hline .360 & .00000052 & $.000 n 0043$ & $.000000>0$ \\
\hline - 380 & - $n \cap 000013$ & - $\cap 0 \cap \cap \cap 034$ & .00000017 \\
\hline $\begin{array}{l}.400 \\
.420\end{array}$ & $\begin{array}{r}.00000003 \\
-.00000002\end{array}$ & $\begin{array}{l}. \cap 00 \cap \cap 018 \\
. \cap 00 \cap 000 B\end{array}$ & $\begin{array}{l}.00000010 \\
.00000002\end{array}$ \\
\hline .440 & $-.00 n 00004$ & $=.0 \cap 0 \cap 0000$ & -.00000000 \\
\hline .460 & $=.0 n 000004$ & -.00000004 & $-.0000000 ?$ \\
\hline .480 & $=.00000010$ & 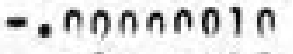 & $=.00000005$ \\
\hline .500 & $=.00000013$ & $=.00 \cap \cap \cap 013$ & $=.0000000 A$ \\
\hline
\end{tabular}


2HT?

DFFLECTIONS FRCM RESPONSF FIINCTIONS ANR LOAN

TIME LOAD,IPS. DEFLECT TON S,IN.

(SEC) $\quad x=0 \quad x=3.25 \quad x=5.75 \quad x=8.75$

\begin{tabular}{|c|c|c|c|c|}
\hline $\begin{array}{r}.00 \\
.02\end{array}$ & $\begin{array}{l}0.0 \\
0.0\end{array}$ & $\begin{array}{l}0.000000 \\
0.0000000\end{array}$ & $\begin{array}{l}0.0 n 0000 \\
\cap . \cap 000000\end{array}$ & $\begin{array}{l}0.0000000 \\
0.0000000\end{array}$ \\
\hline .04 & $\begin{array}{l}200 \cdot n \\
350.0\end{array}$ & $\begin{array}{l}.000120 \\
.000480\end{array}$ & $\begin{array}{l}: \cap 00064 \\
: \cap n 0144\end{array}$ & $\begin{array}{l}.000040 \\
.000134\end{array}$ \\
\hline $\begin{array}{l}.0 R \\
.10\end{array}$ & $\begin{array}{l}375.0 \\
375.0\end{array}$ & $\begin{array}{l}.000600 \\
.000615\end{array}$ & $\begin{array}{l}\text { :nก0>77? } \\
\text {. กn035? }\end{array}$ & $\begin{array}{l}.00016 R \\
.00019 ?\end{array}$ \\
\hline $\begin{array}{r}.12 \\
.14 \\
.16\end{array}$ & $\begin{array}{l}375.0 \\
375.0 \\
375.0\end{array}$ & $\begin{array}{l}.000630 \\
.000645 \\
.000660\end{array}$ & 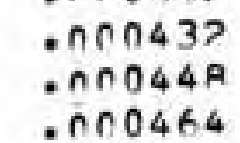 & $\begin{array}{l}.000208 \\
.000 ? 17 \\
.000 ? 16\end{array}$ \\
\hline .18 & 375.0 & .000675 & . $\cap \cap 0472$ & $.000>2 n$ \\
\hline .20 & 375.0 & .000690 & . $\cap \cap 04 P 0$ & .000224 \\
\hline .22 & 0.0 & .000330 & $.0 \cap 035 ?$ & .000174 \\
\hline $\begin{array}{l}.24 \\
.24\end{array}$ & $\begin{array}{l}0.0 \\
0.0\end{array}$ & $\begin{array}{l}.000710 \\
.000180\end{array}$ & 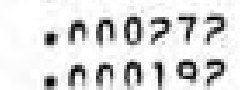 & $\begin{array}{l}.000134 \\
.000094\end{array}$ \\
\hline .28 & $0 . n$ & .000150 & . nn0112 & .000064 \\
\hline .30 & 0.0 & $.0001>0$ & .000080 & $.000 \cap \triangle A$ \\
\hline .32 & $0 . n$ & .000090 & - NOOORA & . \\
\hline .34 & 0.0 & .000075 &.$\cap \cap 004 A$ & $.00002 A$ \\
\hline . 36 & 0.0 & .000060 & .000040 & $.0000>4$ \\
\hline - 38 & 0.0 & .000045 & $=0 \cap 0 \cap 3 ?$ & $.0000>0$ \\
\hline .40 & 0.0 & .000030 & . 100024 & .000016 \\
\hline .42 & 0.0 & $\begin{array}{l}.000015 \\
.000015\end{array}$ & O $\cap \cap 0016$ & $\begin{array}{l}.000012 \\
.00000 R\end{array}$ \\
\hline .46 & 0.0 & .000015 &.$\triangle \cap O O O R$ & .000004 \\
\hline .48 & & .000015 & . $\cap \cap 0008$ & .000004 \\
\hline & & 000015 & $=000008$ & 000004 \\
\hline
\end{tabular}


$2 \mathrm{HI} 7$

RECORD OF PAW DATA

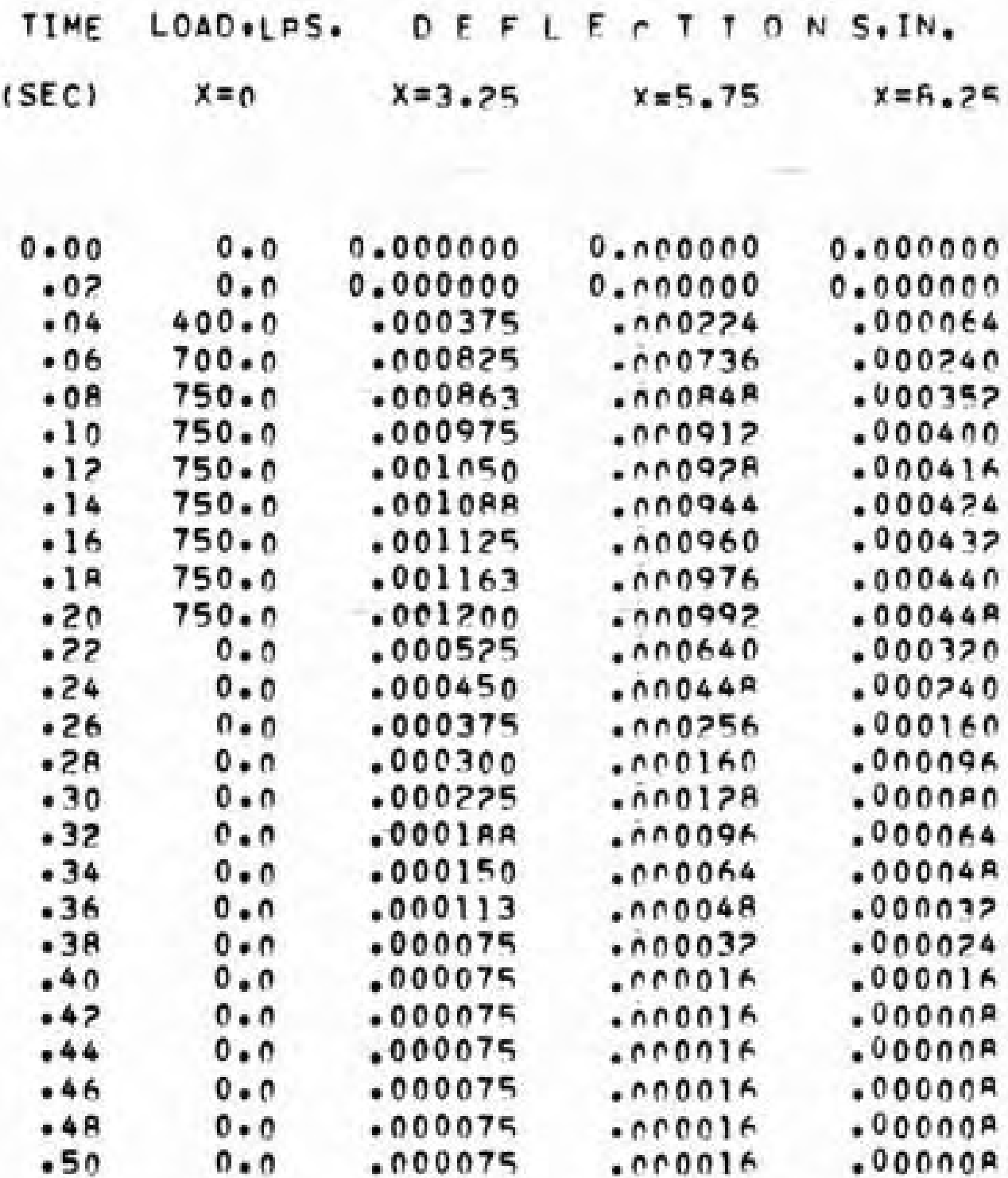


RESPONSE FUNCTIONS FROM TMPI TCIT CONVOLITION

\begin{tabular}{|c|c|c|c|}
\hline (SEC) & $x=3.25$ & $y=6.75$ & $x=A .25$ \\
\hline $\begin{array}{r}0.000 \\
.020\end{array}$ & $\begin{array}{l}.00000250 \\
.01000527\end{array}$ & $\begin{array}{l}\text { on } 0 n 00149 \\
\text { onsonos } 0477\end{array}$ & $\begin{array}{l}.00000063 \\
.000001<6\end{array}$ \\
\hline $\begin{array}{l}.040 \\
.060\end{array}$ & $\begin{array}{l}.01000501 \\
.00000526\end{array}$ & $\begin{array}{l}\text {. DONAO5OK } \\
.00 \cap A \cap \cap 40 R\end{array}$ & $\begin{array}{l}.00000 ? 16 \\
.00000 ? \geqslant 77\end{array}$ \\
\hline $.0 B O$ & .00000523 & . $0 \cap \cap \cap \cap 459$ & $.0000 \cap>15$ \\
\hline .100 & .00000496 & $.0 n \cap n 0423$ & .00000109 \\
\hline .120 & .00000471 & $.000 \cap 039 ?$ & $.000 \cap 0194$ \\
\hline .140 & .00000449 & $.000 \cap 0363$ & .00000171 \\
\hline .160 & .00000429 & .00010337 & .00000159 \\
\hline .180 & $=.00000039$ & . $\triangle O \cap \cap \cap O B 3$ & .00000042 \\
\hline .200 & $=.00000036$ & $=.00000007$ & .00000017 \\
\hline .220 & $=.00000032$ & $=. \cap 0 O A \cap \cap 094$ & -.00000016 \\
\hline .240 & $=.00000026$ & $=.000 n 0091$ & -.00000035 \\
\hline .260 & $=.00000021$ & $=.00000057$ & -.00000071 \\
\hline .280 & .00000005 & -.OACAnO30 & $=.00000010$ \\
\hline .300 & .00000027 & $=.00000009$ & -.00000001 \\
\hline .320 & .00000045 & . OOONOOO1B & .00000006 \\
\hline .340 & .00000058 & .00000039 & $.0000001 \mathrm{~A}$ \\
\hline .360 & .00000048 & .00000032 & .00000015 \\
\hline .380 & .00000040 & $.0001000>9$ & .00000010 \\
\hline .400 & .00000033 & . OANADOOIR & .00000007 \\
\hline .420 & .00000027 & .00000007 & .00000003 \\
\hline .440 & .00000022 & $.00 n \cap 0000$ & .00000001 \\
\hline .460 & .00000020 & $=.00 \cap n D 003$ & $=00000000$ \\
\hline .420 & $=.00000004$ & $=.00000009$ & -.00000003 \\
\hline & & & \\
\hline
\end{tabular}


DEFLECTIONS FROM RESPONSF FUNCTIONS ANO LOAD

TIME LOADILRS. DEFLECT TON S,IN.
(SEC) $x=0 \quad x=3.25 \quad x=5.75 \quad x=8.25$

\begin{tabular}{|c|c|c|c|c|}
\hline $\begin{array}{l}0.00 \\
.02 \\
.04\end{array}$ & $\begin{array}{r}0.0 \\
0.0 \\
400.0\end{array}$ & $\begin{array}{r}0.000000 \\
0.000000 \\
.000375\end{array}$ & $\begin{array}{l}0.0100000 \\
0.000000 \\
.010224\end{array}$ & $\begin{array}{r}0.000000 \\
0.000000 \\
.000064\end{array}$ \\
\hline $\begin{array}{l}.06 \\
.08\end{array}$ & $\begin{array}{l}700.0 \\
750.0\end{array}$ & $\begin{array}{l}.000825 \\
.000863\end{array}$ & 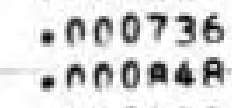 & $\begin{array}{l}.000240 \\
.000349\end{array}$ \\
\hline $\begin{array}{l}110 \\
.12\end{array}$ & $\begin{array}{l}750.0 \\
750.0\end{array}$ & $\begin{array}{l}.000975 \\
.00105 n\end{array}$ & $\begin{array}{l}.010912 \\
.000928\end{array}$ & $\begin{array}{l}.000400 \\
.00041 \mathrm{~h}\end{array}$ \\
\hline $\begin{array}{r}14 \\
.16\end{array}$ & $\begin{array}{l}750.0 \\
750.0\end{array}$ & $\begin{array}{l}.001089 \\
.001125\end{array}$ & $\begin{array}{l}.000944 \\
.000960\end{array}$ & $\begin{array}{l}.000424 \\
.000437\end{array}$ \\
\hline .18 & 750.0 & .001163 & .000976 & .000440 \\
\hline $\begin{array}{l}.20 \\
.22\end{array}$ & $\begin{array}{r}750.0 \\
0.0\end{array}$ & $\begin{array}{l}.001200 \\
.000525\end{array}$ & $\begin{array}{l}\text { inn0992 } \\
\text { OnO0640 }\end{array}$ & $\begin{array}{l}.00044 A \\
.000320\end{array}$ \\
\hline .24 & 0.0 & .000450 & .000448 & $.000>40$ \\
\hline .26 & 0.0 & .000375 & . 100756 & .000160 \\
\hline $.2 \mathrm{~A}$ & 0.0 & .000300 & .000160 & .000096 \\
\hline .30 & 0.0 & .000225 & .000128 & .000000 \\
\hline .32 & & .0001 A7 & .000096 & $.0000 \mathrm{~A}$ \\
\hline .34 & 0.0 & .000150 & .900064 & $.00004 \mathrm{~A}$ \\
\hline .36 & 0.0 & .000112 & .000048 & $.00003 ?$ \\
\hline . $3 A$ & 0.0 & .000075 & .000032 & .000074 \\
\hline .40. & 0.0 & .000075 &.$n n 0016$ & .000016 \\
\hline .42 & 0.0 & .000075 & .000016 & $.00000 \mathrm{~A}$ \\
\hline .44 & 0.0 & .000075 & - $\mathrm{AnOC16}$ & $.00000 \mathrm{~A}$ \\
\hline .46 & 0.0 & .000075 & .000016 & $.00000 A$ \\
\hline .48 & 0.0 & .000075 & .010016 & .00000 A \\
\hline .50 & 0.0 & .000075 &.$n 00016$ & $.00 C O O A$ \\
\hline
\end{tabular}


APPENDIX B

STATIC LOAD PROGRAM 
PROGRAM STALOD (INPUT, OUTPUT, TAPE5=INPUT , TAPE6=OUTPUT)

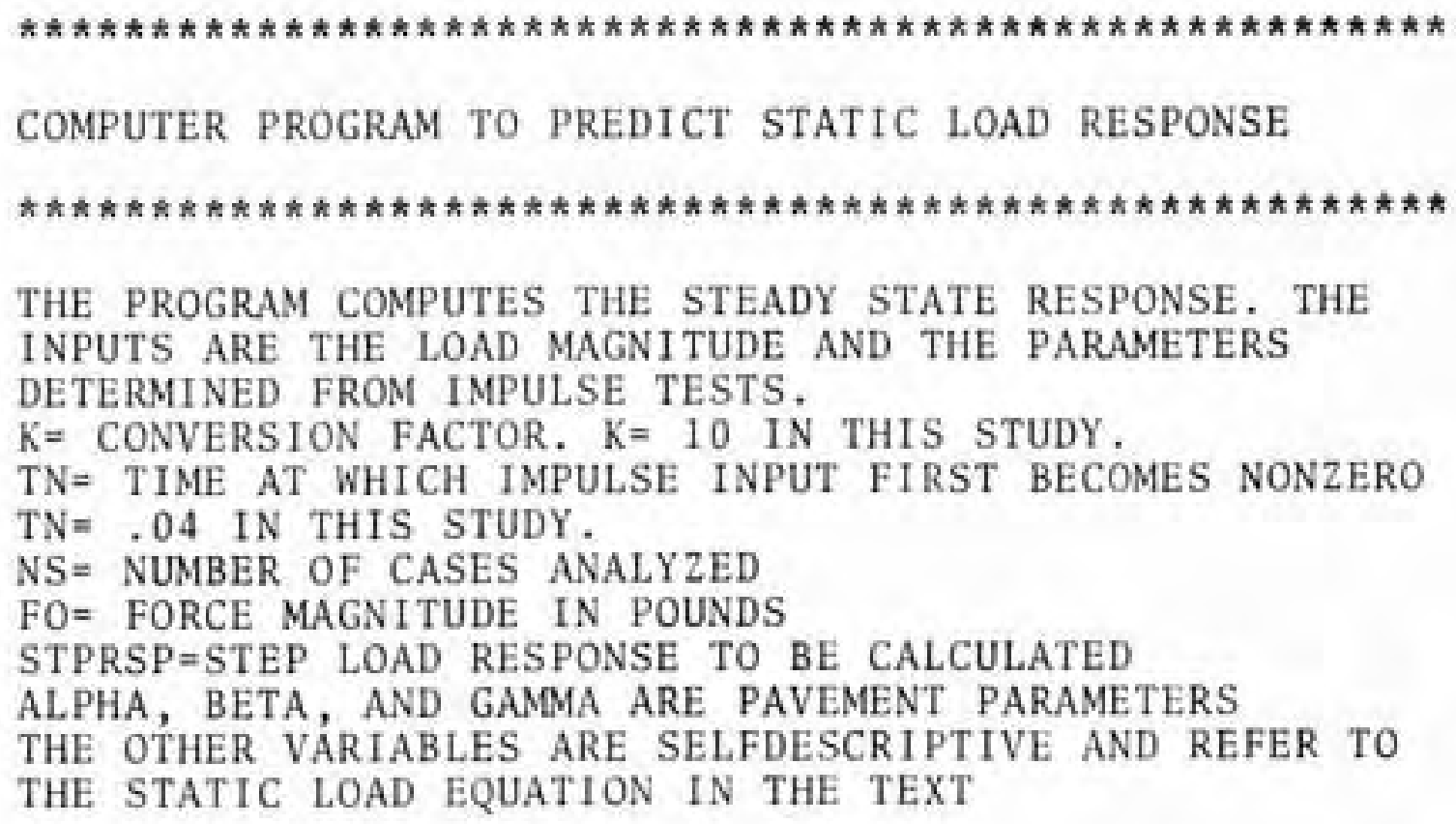

DIMENSION LABLE (4)

\section{INTEGER LABLE}

REAL $K$

$\operatorname{READ}(5,1)$ NS , K, TN

DO $99 \mathrm{I}=1$, NS

$\operatorname{READ}(5,2)(\operatorname{LABLE}(\mathrm{J}), \mathrm{J}=1,3)$, FO

$\operatorname{READ}(5,3)$ ALPHA, BETA, GAMMA

$\mathrm{DEN}=\mathrm{BETA}^{*} * 2+\mathrm{GAMMA} * * 2$

ROTDEN $=$ SQRT $(D E N)$

TANPHI $=$ GAMMA $/$ BETA

PHI $=$ ATAN $($ TANPH I )

ARGSIN $=$ GAMMA * $T N+P H I$

STPRSP $=$ FO*ALPHA ${ }^{*}\left(K^{*}\right.$ GAMMA $/$ DEN $-(K-1$.$) / ROTDEN*EXP \left(-\right.$ BETA* $^{*}$ $1 \mathrm{TN}) * \operatorname{SIN}(\operatorname{ARGSIN}))$

C MULTIPLY RESULT BY 10000 FOR PRESENTATION STPRSP $=$ STPRSP $* 10000$.

C THE FOLLOWING IF STATEMENTS ALLOW PRINTING CERTAIN

C GROUPS OF RESULTS CN ONE PAGE
IF (I.EQ. 1) GO TO 20
IF (I.EQ. 7) GO TO 20
IF (I.EQ.16) GO TO 20
IF (I.EQ.25) GO TO 20
IF (I.EQ.34) GO TO 20
IF (I.EQ.43) GO TO 20 


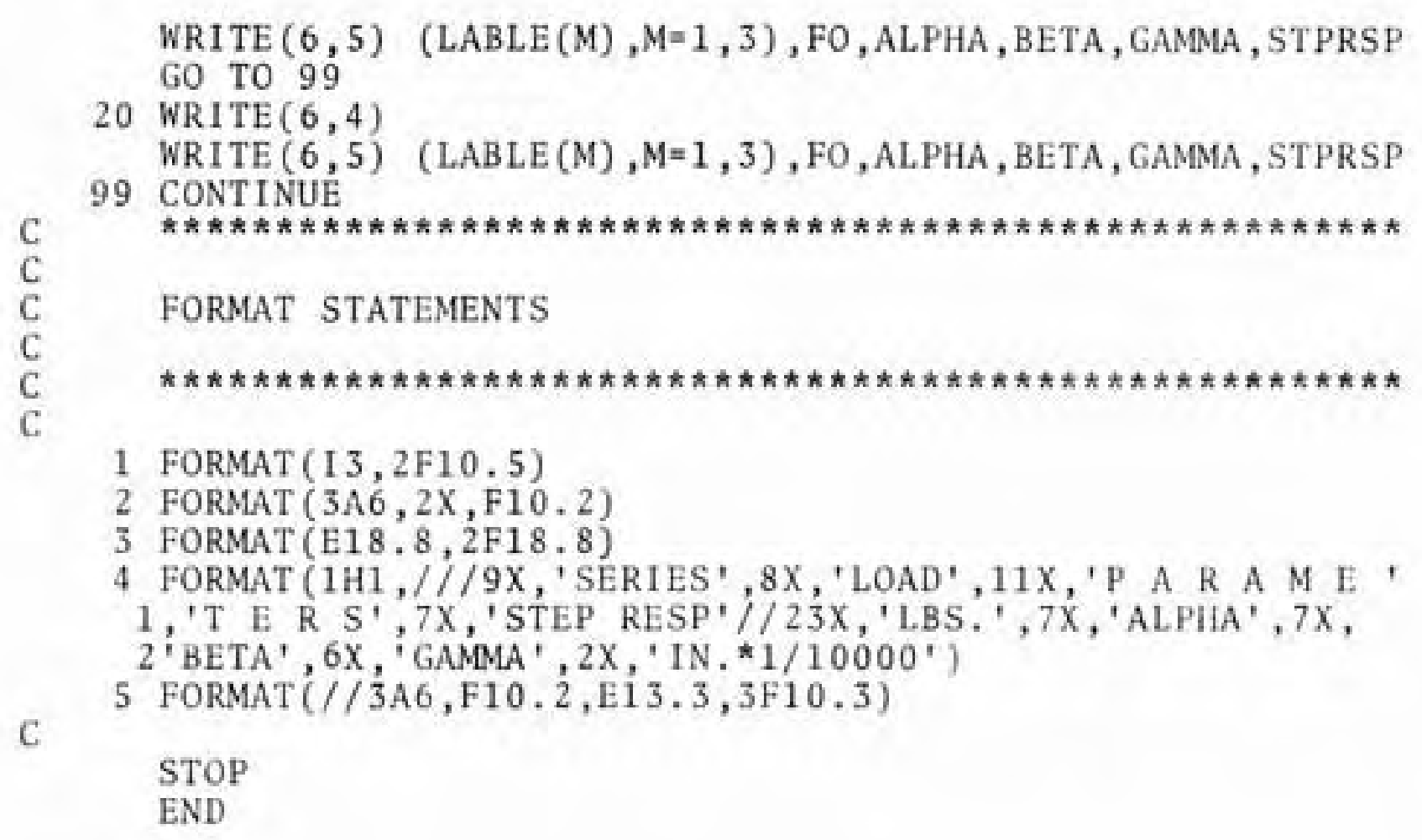


APPENDIX C

REPEATED LOAD PROGRAM 
PROGRAM REPLOD (INPUT, OUTPUT, TAPE 5= INPUT, TAPE $6=0 U T P U T$ )

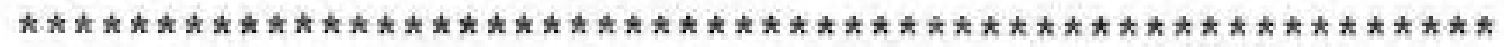

COMPUTER PROGRAM TO PREDICT REPEATED LOAD RESPONSE:

$* * * * * * * * * * * * * * * * * * * * * * * * * * * * * * * * * * * * * * * * * * * * * * * * * * * * * *$

THE PROGRAM COMPUTES THE TIME-DEPENDENT RESPONSE OF

THE SYSTEM. THE INPUTS ARE THE RATE (OR DURATION) AND

THE AMPLITUDE OF THE LOADING FUNCTION, AND THE PARAMETERS

DETERMINED FROM IMPULSE TESTS.

$K=$ CONVERSION FACTOR. $K=10$ IN THIS STUDY.

TN $=$ TIME AT WHICH IMPULSE INPUT FIRST BECOMES NONZERO.

TN $=.04$ IN THIS STUDY.

$\mathrm{FO}=$ AMPLITUDE OF REPEATED LOADING FUNCTION.

$\mathrm{P}=$ PERIOD OF LOADING.

ALPHA, BETA AND GAMMA ARE PAVEMENT PARAMETERS.

$\mathrm{NS}=$ NUMBER OF CASES ANALYZED.

$\mathrm{NP}=$ NUMBER OF PREDICTIONS DESIRED FOR EACH CASE.

$\mathrm{N}=$ NUMBER OF LOAD APPLICATIONS.

TPEAK = TIME WHEN THE LOAD IS AT PEAK POSITION AFTER N LOAD APPLICATIONS.

RPEAK = RESPONSE WHEN THE LOAD IS AT PEAK POSITION

AFTER N LOAD APPLICATIONS.

TOFPK $=$ TIME WHEN LOAD IS AT OFF PEAK POSITION AFTER N LOAD APPLICATIONS.

ROFPK $=$ RESPONSE WHEN LOAD IS AT OFF PEAK POSITION AFTER N LOAD APPLICATIONS.

THE OTHER VARIABLES ARE SELFDESCRIPTIVE AND REFER TO

THE REPEATED LOAD EQUATIONS IN THE TEXT.

DIMENSION LABLE (11)

INTEGER LABLE

REAL K

$\operatorname{READ}(5,1)$ NS , NP, P, K, TN

DO $200 \mathrm{M}=1$, NS

WRITE $(6,2)$

$\operatorname{READ}(5,3)(\operatorname{LABLE}(\mathrm{J}), \mathrm{J}=1,11)$, $\mathrm{FO}$

$\operatorname{READ}(5,4)$ ALPHA, BETA, GAMMA

WRITE $(6,5) \quad(\operatorname{LABLE}(J), J=1,11)$

WRITE $(6,6)$ FO

WRITE $(6,7)$ ALPHA, BETA, GAMMA 


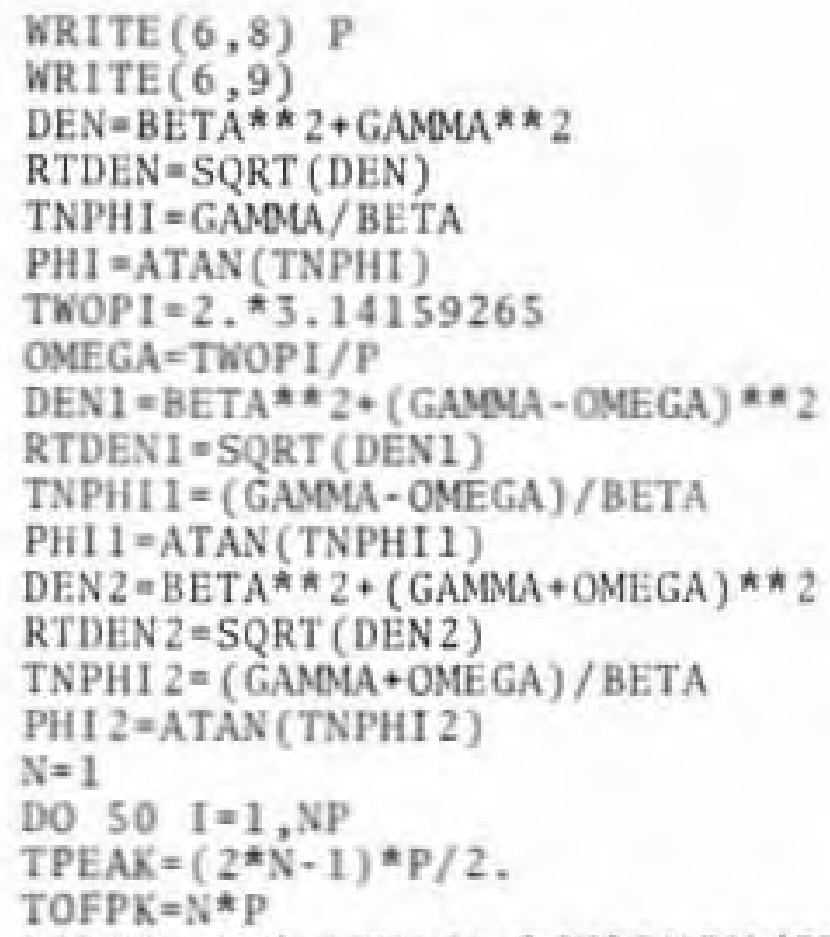

RPEAK $=$ FO*ALPHA $/ 2{ }^{*}\left(K^{*}\right.$ GAMMA $/$ DEN $+K / 2 *^{*}(($ GAMMA - OMEGA $) / D E N 1$ $1+($ GAMMA+OMEGA $) / D E N 2)-(K-1,) / \operatorname{RTDEN}^{*} \operatorname{EXP}\left(-\mathrm{BETA}{ }^{*} T N\right) * \operatorname{SIN}($ 2 GAMMA*TN + PHI $)-(K-1,) / 2 *^{*}($ EXP $(-B E T A * T N) / T R D H N 1 * S 1 N(($ 3 GAMMA-OMEGA $) * T N+P H I 1)+\operatorname{EXP}(-B E T A * T N) / R T D E N 2 * \operatorname{SIN}(($ GAMMA + 4OMEGA) *TN+PHI 2)) - EXP (-BETA*TPEAK) /RTDEN*SIN (GAMMA*TPEAK $5+\mathrm{PHI})-.5 *($ EXP $(-$ BETA*TPEAK $) /$ RTDEN1 *SIN $(($ GAMMA-OMEGA $)$ * $6 T P E A K+P H I 1)+\operatorname{EXP}(-B E T A * T P E A K) / R T D E N 2 * S I N((G A M M A+O M E G A) *$ 7TPE.AK + PHI 2)))

ROFPK $=$ FO*ALPHA $/ 2,{ }^{*}\left(K^{*}\right.$ GAMMA $/ D E N-K / 2,{ }^{*}(($ GAMMA-OMEGA $) / D E N 1$ $1+($ GAMMA+OMEGA $) / D E N 2)-(K-1.) / R T D E N^{*} \operatorname{EXP}\left(-B^{*} A^{*} T N\right) * S 1 N($ 2 GAMMA*TN $+\mathrm{PHI})+(\mathrm{K}-1) / 2,,{ }^{*}$ EXP $\left(-\mathrm{BETA}^{*} \mathrm{TN}\right) / \mathrm{RTDEN} 1{ }^{*} \mathrm{SIN}(($ 3 GAMMA - OMEGA)*TN+PHI 1$)+$ EXP $(-B E T A * T N) / R T D E N 2 \star S I N(($ GAMMA + 4 OMEGA)*TN+PH1 2)) - EXP (-BETA*TOFPK)/RTDEN*SIN (GAMMA*TOFPK $5+\mathrm{PHI})+.5 *(\operatorname{EXP}(-\mathrm{BETA} *$ TOFPK $) /$ RTDEN $1 * \operatorname{SIN}(($ GAMMA-OMEGA $)$ * 6 TOFPK +PH1 1$)+\operatorname{EXP}(-$ BETA*TOFPK $) /$ RTDFN2*SIN $(($ GAMMA+OMEGA $)$ * $7 T O F P K+$ PHI 2$))$ )

WRITE $(6,10)$ TPEAK, RPEAK, TOFPK, ROFPK

$50 \mathrm{~N}=\mathrm{N}+1$

C
C
C
C
C
C
C

200 CONTINUE

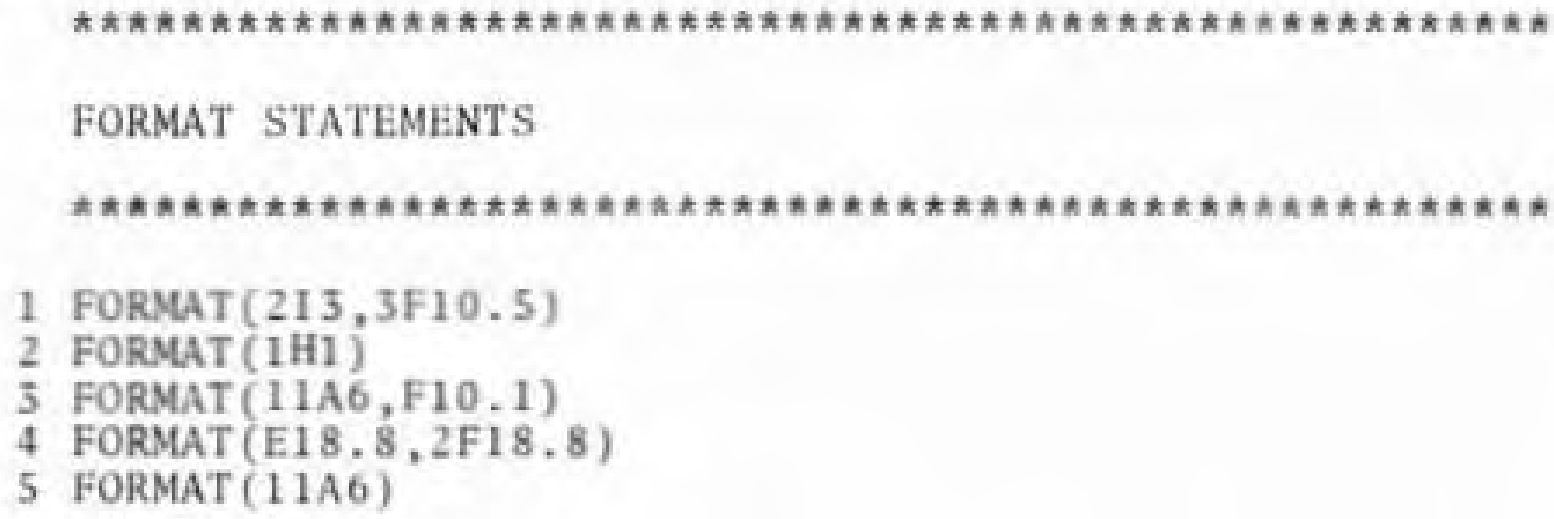


6 FORMAT ( ///6X, 'THE LOAD MAGNITUDE $=$ ',F10.1,' LBS.')

7 FORMAT $\left(/ / / 6 \mathrm{X},{ }^{\prime}\right.$ 'THE PARAMETERS ARE',$/ / 8 \mathrm{X}$, 'ALPHA=', E1 2.3 , 1' $\quad B E T A=1, F 8.3,1 \quad$ GAMMA $=1, F 8.3$ )

8 FORMAT $\left(/ / 6 \mathrm{X}\right.$, 'THE PERIOD $='$, F10.5,' SEC. $\left.{ }^{\prime}\right)$

9 FORMAT (///8X, 'TPEAK', $4 \mathrm{X}$, 'PEAK RESPONSE' , 5X, 'TOFPK' , 5X, 1 'OFFPK RESPONSE')

C

10 FORMAT (//5X,E9.2,E14.3,E14.2,E15.3)

C

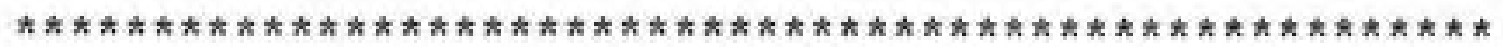

$\mathrm{C}$

STOP

END 
VITA 
VITA

Galal Abdalla Ali was born on January 1, 1941 in Saysab, Northern Province, Sudan. He attended the Abri Elementary and Intermediate Schools. His Secondary School education was completed at Wadi Seidna, Omdurman in April 1960. He received his Bachelor of Science degree in Engineering from University of Khartoum, Khartoum, with First Class Honors in April 1966.

After graduation, the author was employed as a Demonstrator in the Department of Civil Engineering, University of Khartoum.

In September 1966, he came to the United States of America and received his degree of Master of Science in Highway Engineering from Northwestern University in August, 1967.

In September 1967, he entered Purdue University to pursue his studies toward the Ph.D. in highway materials. $\mathrm{Mr} . \mathrm{Ali}$ is an associate member of the American Society of Civil Engineers, a student member of the Institute of Traffic Engineers and an individual supporting member of the Highway Research Board.

He has to his credit one technical paper. Mr. Ali is a citizen of Sudan. He is married and has two children. 